UNIVERSIDADE DE SÃO PAULO

ESCOLA DE COMUNICAÇÕES E ARTES

MARIA BERENICE SIMÕES DE ALMEIDA

Processos criativos no ensino de piano

São Paulo 2014 


\section{Processos criativos no ensino de piano}

Dissertação apresentada ao Programa de Pós-graduação do Departamento de Música da Escola de Comunicações e Artes da Universidade de São Paulo, como parte das exigências para a obtenção do título de Mestre em Música.

área: Processos de Criação Musical orientador: Maria Teresa Alencar de Brito 
ALMEIDA, M. B. S. Processos criativos no ensino de piano. Dissertação apresentada ao Programa de Pós-graduação do Departamento de Música da Escola de Comunicações e Artes da Universidade de São Paulo, como parte das exigências para a obtenção do título de Mestre em Música.

Aprovada em:

BANCA EXAMINADORA

Prof. Dr. Instituição:

Julgamento: Assinatura:

Prof. Dr. Instituição:

Julgamento: Assinatura:

Prof. Dr. Instituição:

Julgamento: Assinatura: 
a meus pais, a Américo (in memoriam) e a Inês, que me indicaram o caminho do encantamento com a vida, permeado pela música;

às crianças que vêm tomando lugar na minha vida ao longo de décadas e me proporcionam, a cada dia, novas descobertas sobre uma possível relação criativa e prazerosa entre música-professor-aluno. 


\section{AGRADECIMENTOS}

Às crianças, alunos presentes e ausentes nesta dissertação, meus verdadeiros mestres.

A minha orientadora, Maria Teresa Alencar de Brito, pelo cuidado e carinho com que acompanhou este trabalho. E, como não poderia deixar de recordar, pelo primeiro exemplo e orientação do meu caminho como educadora musical, despertando em mim um olhar e uma escuta sensível às vozes das crianças.

À $\operatorname{Prof}^{\mathrm{a}} \operatorname{Dr}^{\mathrm{a}}$ Marisa Fonterrada e ao Prof. Dr. Pedro Paulo Salles, pelas preciosas contribuições na banca de qualificação.

Às educadoras musicais, pela disponibilidade de fornecer informações para esta pesquisa, Ana Consuelo Ramos Fernanda Fontoura, Gislene Marino, Laura Longo, María José Zabala, Maria Lúcia Pascoal, Marisa Fonterrada, Mirian Tuñez e Violeta Hemsy de Gainza.

À preciosa ajuda na tradução do alemão de Renate Christina Becker.

À carinhosa ajuda na tradução para o inglês de Marcella Almeida e Márcia Costa.

À competente revisão da Confraria de Textos, na pessoa de Ana Luiza Saad Pereira.

Ao Prof. Dr. Rogério Luiz Moraes Costa, por me mostrar os encantos da livre improvisação.

À Prof ${ }^{\mathrm{a}} \operatorname{Dr}^{\mathrm{a}}$ Susana Cecília Igayara, pelo exemplo de competência na pesquisa acadêmica.

Ao Prof. Dr. Paulo Castagna, por me despertar para as ideias de grandes pensadores e cientistas.

À diretora da EMIA, Andrea Fraga, e sua equipe - assistente pedagógico, assistente artístico e coordenadoras -, Cristina Rogatko, Evandro Brito da Silveira, Giselle Ramos, Liseti Bonamin, Milene Perez, Priscilla Vilas Boas e Sandra Cunha. [em ordem alfabética]

À ex-diretora da EMIA, Márcia Andrade, pelo apoio no início desta dissertação.

A Claudio, Laura e Arthur, pela compreensão de minha ausência familiar, consequência de tantas horas de estudo.

A Alzira, pela compreensão da ausência nos almoços de domingo.

A minha mãe, a tia Aninha e a meus irmãos, cunhadas e cunhados, pelo apoio familiar incondicional.

À querida Mércia, por seu carinho e dedicação ao cuidar do cotidiano de minha família e de minha casa.

A Magda Pucci, pela amizade, pelo apoio e pela observações, tão pertinentes, na leitura desta dissertação.

Às companheiras de encantamentos e questionamentos acadêmicos: Ana Cristina Rossetto Rocha, Claudia Freixedas, Giselle Ramos, Laura Longo, Márcia Lágua, Maristela Loureiro, Liliana Bertolini e Sandra Cunha.

À EMIA, povoada por tantos amigos e profissionais maravilhosos, que vêm me inspirando ao longo de 24 anos. 
Oh tristeza, me desculpe

Estou de malas prontas Hoje a poesia veio ao meu encontro Já raiou o dia, vamos viajar

Vamos indo de carona Na garupa leve do vento macio Que vem caminhando Desde muito longe, lá do fim do mar Vamos visitar a estrela da manhã raiada Que pensei perdida pela madrugada Mas que vai escondida Querendo brincar

Senta nesta nuvem clara Minha poesia, anda, se prepara Traz uma cantiga Vamos espalhando música no ar...

João de Aquino e Paulo César Pinheiro, eternizada na voz de Marisa 


\section{RESUMO}

ALMEIDA, M. B. S. Processos criativos no ensino de piano. 2014. 189 f. Dissertação (Mestrado em Música) - Escola de Comunicações e Artes, Universidade de São Paulo, São Paulo, 2014.

Da longa experiência em sala de aula fazendo música com crianças, surgiu a questão: por que o espaço para a criação não faz parte da maioria dos métodos e das práticas dos professores de piano? Esse questionamento levou a outros sobre como ensinar piano criativamente e como guiar a construção do pensamento musical das crianças. Sem rejeitar os aspectos técnicos, a notação tradicional e a prática de música erudita na formação pianística, a busca por novas possibilidades de ensino vinha da consideração de que não se deveria restringi-lo a um repertório limitado, a um só tipo de notação e à interpretação como única forma de expressão musical. O constante desafio oferecido por alunos curiosos, indagadores, vibrantes e musicais também me impulsionou a olhar mais atentamente para suas produções musicais e a ouvir suas ideias sobre seu fazer musical. A partir dessas considerações, esta dissertação propõe uma reflexão pedagógico-musical disparada por relatos de experiência com meus alunos de piano da Escola Municipal de Iniciação Artística (EMIA). Apresento quatro composições, uma livre improvisação e duas entrevistas livres. Uma breve história do ensino de piano no Brasil e uma revisão concisa de métodos adotados na pedagogia pianística brasileira fundamentam historicamente esta pesquisa. Também analiso alguns que apresentam propostas de criação. Como referencial teórico, exponho as ideias de Hans-Joachim Koellreutter (19152005) e de Violeta Hemsy de Gainza (1930-) sobre um fazer musical criativo e a necessária transformação da relação professor-aluno para que se desenvolva uma educação musical mais aberta. Discorro também sobre as ideias da pianista Moema Craveiro Campos e das educadoras musicais Maria Teresa Alencar de Brito e Viviane Beineke, profundamente ligadas ao pensamento de Koellreutter e Gainza. Contribuem, ainda, com esse corpus, conceitos sobre criatividade defendidos por pesquisadores ingleses das últimas décadas Pamela Burnard, Anna Craft, Teresa Cremin e Bob Jeffrey -, como aprendizagem criativa, possibility thinking e voz do aluno. As reflexões aqui apresentadas visam contribuir com a educação musical através do piano, para que seja agenciadora de encontros criativos entre crianças e músicas.

Palavras-chave: Ensino de piano. Piano. Educação musical. Criatividade. Composições musicais de crianças. 


\begin{abstract}
ALMEIDA, M. B. S. Creative processes in piano teaching. 2014. 189 f. Dissertação (Mestrado em Música) - Escola de Comunicações e Artes, Universidade de São Paulo, São Paulo, 2014.

After many years teaching music to children a concern appeared: why is there no room for creativity in the majority of the methods and practices of piano teachers? This question brought up others such as how to teach piano in a creative matter and how to guide children towards thinking in a musical mind set. Without ignoring the technical aspects, traditional notation and classical music training, the search for new possible teaching methods must not restrict the ability to establish full repertoire, the capacity to utilize multiple notation methods and the understanding that interpretation is not the only form of musical expression. The constant challenge offered by students who were curious, musical and vibrant spurred me to look more closely at their musical production and to listen to their ideas about making music. With these considerations in mind, this dissertation offers a reflection that is both musical and pedagogical based on my experiences with piano students from Escola Municipal de Iniciação Artística (EMIA). This research is supported by a concise review of methods used historically in the piano pedagogy of Brazil. I present four compositions, a free improvisation and two free interviews. My sciencitific resources are based on Hans-Joachim Koellreutter (19152005) and Violeta Hemsy de Gainza's (1930-) ideas about making creative music and the necessity of a bond between teacher and student in order to develop a more open musical education. Moreover, I discuss the ideas of pianist Moema Craveiro Campos and the musical educators Maria Teresa Alencar de Brito and Viviane Beineke, while also showing interest in Koellereutter and Gainza's concepts. Contributing further to this corpus are the concepts of creativity (creative learning, possibility thinking and student voice) presented by English researchers of the last decades such as Pamela Burnard, Anna Craft, Teresa Cremin and Bob Jeffrey. The ideas presented here are intended to contribute to musical education through the use of the piano. In turn, this education will facilitate creative encounters between music and children.
\end{abstract}

Keywords: Piano teaching. Piano. Music education. Creativity. Children musical composition. 


\section{SUMÁRIO}

Introdução

CAPÍTULO 1

$\mathrm{O}$ ensino de piano

CAPÍTULO 2

Criatividade

CAPÍTULO 3

Reflexões pedagógico-musicais sobre as composições e depoimentos das crianças

3.1 O contexto: a EMIA

3.2 "Música sem título"

3.3 "Mistério"

3.4 "O gigante" e "Ideia musical"

Considerações finais

Referências

Anexo A - Carta à direção da EMIA

Anexo B - Comunicado e pedido de autorização aos pais 188

Anexo C - Autorização 


\title{
INTRODUÇÃO
}

\author{
O tempo presente e o tempo passado \\ Estão ambos talvez presentes no tempo futuro \\ E o tempo futuro contido no tempo passado [...]
}

T. S. Eliot

Logo nos primeiros anos de minha atuação profissional, comecei a questionar a forma tradicional de ensinar música, na qual eu mesma tinha sido iniciada, e me vi desafiada frente aos meus alunos - crianças curiosas, vibrantes, questionadoras e musicais. Quando, além de professora de piano em aulas individuais, me tornei professora de música em escolas de educação infantil e do ensino fundamental, as dúvidas foram aumentando e tomando contornos cada vez mais definidos.

No contato diário com as crianças, pude observar a diferença entre a espontaneidade que demonstravam ao fazer música em momentos mais livres, como nos intervalos, e certa apatia diante de exercícios de leitura e outras atividades propostas em aula. Essa constatação me inquietou por anos. Dentre diversos questionamentos, o maior deles era em relação ao espaço mínimo, quase inexistente, dedicado à criação no ensino tradicional de música e, em especial, no de piano. Destaco que essa orientação pedagógica era a encontrada na maioria dos conservatórios e instituições musicais similares e mesmo em aulas particulares.

Os princípios básicos da pedagogia pianística tradicional eram a aquisição do conhecimento musical pela compreensão intelectual, a valorização da leitura e da escrita tradicional, o desenvolvimento técnico e a prática de um repertório de música centro-europeia limitado entre o período Barroco e princípios do século XX. Apesar das grandes transformações na educação musical, ${ }^{1}$ a pedagogia pianística permaneceu basicamente a mesma e, mesmo após a primeira década do século XXI, os eixos norteadores do ensino tradicional de piano ainda estão presentes em diversos contextos musicais do país.

A reflexão sobre essas questões me causou uma premente necessidade de mudança e me impulsionou a buscar formas mais criativas de ensinar piano, abordagens que levassem a uma educação musical mais ampla e aberta. Essa busca por novas possibilidades de ensino não vinha da rejeição ou desvalorização dos aspectos técnicos, da notação tradicional e da

\footnotetext{
${ }^{1}$ Podem-se citar os métodos ativos da primeira metade do século XX, a mudança de foco para a criatividade, deflagrada por compositores na década de 1960, e a prática reflexiva das últimas décadas daquele século. Para maiores informações sobre o tema, pesquisar: Fonterrada (2005), Gainza (2002; 2013), Mateiro e Ilari (2011) e Jordão et al. (2012).
} 
prática de música erudita na formação pianística, mas da consideração de que não se deveria restringir a abordagem de educação pianística a um tipo de repertório, um tipo de notação e à interpretação como única forma de expressão musical.

A partir de erros e acertos das novas propostas que experimentava nas aulas de piano, surgiram novas perguntas que me levaram à pesquisa e à reflexão. Quais princípios devem orientar a prática pedagógico-musical do professor para favorecer os processos criativos? Que materiais podem fundamentar teórica e metodologicamente essa prática? O protagonismo do aluno é condição fundamental para um aprendizado criativo e significativo? É possível identificar caminhos de construção de um pensamento musical por meio das composições das crianças? Que pistas as composições das crianças nos fornecem sobre seu aprendizado dos conceitos musicais?

Nesta dissertação, proponho uma reflexão a partir de referenciais teóricos que iluminem os caminhos a serem traçados e de minha própria experiência profissional. Dessa trajetória educacional, cito duas experiências fundamentais: os dez anos como professora de piano na Teca-Oficina de Música, ${ }^{2}$ lugar que despertou minha busca por um olhar sensível para as crianças e para o espaço da criatividade no ensino musical, e os mais de 23 anos como professora de música e de piano na EMIA, ${ }^{3}$ lecionando com colegas de outras linguagens artísticas, para as quais o processo criativo é sempre o primeiro passo para o aprendizado e a sedimentação do conhecimento teórico das crianças.

Para fundamentar a reflexão e inseri-la num contexto histórico, inicio o primeiro capítulo com uma síntese da história do ensino tradicional de piano no país, que se desenvolveu em meio à efervescência cultural e educacional promovida pela Família Real portuguesa desde sua chegada, em 1808. Dentre diversos fatos e iniciativas que estimularam a vida musical da época, o crescente número de professores particulares de piano, entre eles renomados pianistas, e a valorização da cultura europeia pelas famílias mais abastadas transformaram o piano em símbolo de status. Assim, iniciou-se no Brasil Colônia e no Brasil Império uma cultura pianística, que Mário de Andrade mais tarde denominou pianolatria. ${ }^{4}$

\footnotetext{
${ }^{2}$ Teca-Oficina de Música é uma escola de música privada de São Paulo, que, há mais de 30 anos, atende crianças a partir dos 3 anos, assim como jovens e adultos.

3 A EMIA (Escola Municipal de Iniciação Artística) foi fundada em 1980 e pertence ao Departamento de Expansão Cultural da Secretaria Municipal de Cultura da cidade de São Paulo.

${ }^{4}$ Pianolatria é o termo usado por Mário de Andrade para criticar fato de que toda moça da elite estudava piano por questão de status. Foi também o título de um artigo que o autor publicou na revista Klaxon: mensário de Arte Moderna (ANDRADE, 1922, p. 8).
} 
No mesmo capítulo, apresento os conteúdos pedagógico-musicais de grande parte dos métodos de iniciação ao piano adotados no país, buscando identificar um maior ou menor espaço para a criação no ensino do instrumento. Sem a pretensão de fazer uma extensa revisão bibliográfica, discorro sucintamente sobre os fundamentos pedagógicos encontrados.

Para a última parte do capítulo 1, selecionei 11 livros para piano que tinham aspectos criativos em suas propostas. A partir de um verbete biográfico do autor e uma síntese dos eixos pedagógicos norteadores do método, aponto materiais que, ao longo dos séculos XX e XXI, confirmam a possibilidade de se inserir o espaço da criação no ensino de piano. Os autores selecionados são: Robert Pace, Ernest Widmer, György Kurtág, Violeta Hemsy de Gainza, Marisa Fonterrada e Maria Lúcia Pascoal, Harald Bojé, Maria de Lourdes Junqueira Gonçalves e Cacilda Borges Barbosa, Fernanda Fontoura, Ana Consuelo Ramos e Gislene Marino, Laura Longo, María José Zabala e Mirian Tuñez.

O tema do segundo capítulo é a criatividade. Inicio com as principais ideias de HansJoachim Koellreutter (1915-2005), músico alemão naturalizado brasileiro, dialogando, a seguir, com o pensamento da educadora musical argentina Violeta Hemsy de Gainza (1930- ). Esses dois educadores constituem os pilares da reflexão sobre criatividade apresentada nesta dissertação, mas apresento outras referências importantes, que revelam conexões profundas com o pensamento de ambos e entre si. São as ideias da pianista Moema Craveiro Campos e das educadoras musicais Maria Teresa Alencar de Brito e Viviane Beineke.

Ainda no capítulo 2, apresento contribuições da psicologia à pesquisa sobre criatividade a partir da década de 1950 e aspectos relativos à criatividade na educação e a complexidade da situação de ensino e aprendizagem em sala de aula, segundo a pesquisadora inglesa Anna Craft. Para finalizar, a partir de textos de Pamela Burnard, Teresa Cremmin, Jeffrey Bob e novamente Craft, discorro brevemente sobre conceitos que vêm ocupando as pesquisas inglesas mais recentes sobre criatividade: aprendizagem criativa, possibility thinking e voz do aluno.

O cerne do capítulo 3 é a própria razão deste trabalho, pois foram as músicas das crianças que me levaram a refletir sobre o que elas poderiam revelar e de que forma o espaço da criação poderia ser cada vez mais estimulado no ensino pianístico. Assim, nesse capítulo, descrevo e examino musical e pedagogicamente quatro composições, uma improvisação e duas entrevistas livres nas quais os alunos discorrem sobre seu processo criativo. Em cada um 
dos exemplos, um determinado aspecto é disparador das reflexões. As crianças envolvidas neste estudo são alunos da EMIA e frequentam cursos de artes visuais, dança, música e teatro, paralelamente às aulas de piano.

Começo com "Música sem título", composta por Beatriz. 5 Descrevo algumas atividades de pesquisa das possibilidades sonoras do piano feitas com a aluna e dou referências teóricas que fundamentam essa prática. Em seguida, contextualizo uma improvisação livre a quatro mãos e analiso sua construção musical para entender como se operou o pensamento musical de Beatriz. Por último, a própria música dispara reflexões pedagógico-musicais sobre a composição, apoiadas em falas de Beatriz gravadas em vídeo durante o processo criativo.

Outra composição estudada é "Mistério", de Laura. Apresento a construção da música e o depoimento da aluna, no formato de uma entrevista livre, no qual ela discorre sobre seu processo de criação. A reflexão pedagógico-musical apresentada pretende entender melhor recursos e estratégias usados por ela e discutir possíveis formas de conduzir a aula para estimular a criatividade, considerando os processos criativos como facilitadores da apropriação de conteúdos musicais pelos alunos.

Os dois últimos exemplos são "O gigante" e "Ideia musical", composições de Arthur. "O gigante" é uma breve história musicada inventada a partir de uma atividade de experimentação sonora do piano aberto. Reflito sobre a associação de sonoridades e o imaginário das crianças, revelada em um processo criativo numa situação específica. Descrevo o processo de composição e discuto a singularidade de cada criança em seu processo de aprendizado. "Ideia musical" resultou num trabalho de notação musical sobre o qual discorro no final do capítulo. Arthur usou três notações diferentes para registrar sua ideia: partitura com número de teclas, partitura com nome de notas e partitura com pentagrama. A partir delas e da explicação do próprio aluno sobre o processo de criação de suas partituras, conduzo uma reflexão que tem dois focos principais: a construção do pensamento de Arthur em relação ao registro e a possibilidade de incluir diferentes notações no aprendizado musical. Também reflito sobre a postura tradicional do professor, a valorização da singularidade e a possibilidade de dar voz às crianças.

\footnotetext{
${ }^{5}$ Os nomes das crianças aqui apresentados são fictícios. No Anexo A, está a carta Carta à direção da EMIA; no Anexo B, o Comunicado e pedido de autorização aos pais; no Anexo C, a Autorização dos pais.
} 


\section{Considerações metodológicas}

O material selecionado para essa pesquisa foram as composições, a livre improvisação e os depoimentos gravados em vídeo. Esclareço que essa gravação não foi feita especialmente para este trabalho, mas na época da criação das músicas.

Considero que ouvir ou assistir a própria performance permite ao aluno ter maior consciência sobre aspectos musicais e extramusicais, por isso, há alguns anos, mantenho o hábito de gravar em vídeo e áudio alguns momentos da aula, usando-os como recurso de reflexão com as crianças. Gainza (2002, p. 52-53) enfatiza a importância da participação do aluno, estimulando-o a verbalizar o surgimento das ideias, o que sentiu, o que ainda precisa entender etc. Ela também indica ao professor duas tarefas que considera essenciais e complementares: "de um lado, proporcionar experiência por meio da apresentação de novos materiais sonoros, e, do outro, propiciar a consciência de materiais, estruturas e processos musicais internalizados de maneira empírica ou espontânea"“6 ( GAINZA, 2002, p. 52 e 53, tradução nossa, grifos do original). Pode-se encontrar em Burnard (2000, p. 21, tradução nossa) uma ênfase na reflexão participativa do aluno sobre seu próprio processo: "precisamos encorajar e ajudar as crianças a pensar crítica e criativamente [...]. As crianças devem ser encorajadas a discutir o que é intrínseco a sua própria experiência musical". 7

Usei três critérios para selecionar o material de estudo:

- que as composições fossem de alunos da mesma instituição, inseridos num mesmo contexto educacional. Apesar de haver um currículo comum, na EMIA cada aluno trilha um caminho bastante pessoal; há diferenças em relação aos professores de cada aluno ao longo dos anos e às escolhas individuais de cursos optativos e, nos últimos dois anos de curso, da linguagem artística com que o aluno mais se identifica;

- que houvesse diversidade de propostas de criação. Embora todas as composições selecionadas tenham surgido da exploração sonora do piano, são bem diferentes entre si. As primeiras são uma livre improvisação e uma composição dela derivada, ambas executadas com o piano aberto. A terceira é tocada no teclado do piano e focada num elemento específico da linguagem musical: o cromatismo. A quarta usa

\footnotetext{
6 “[...] por una parte, dar experiencia mediante la presentación de nuevos materiales sonoros, y por otra, dar conciencia de los materiales, estructuras y processos musicales internalizados de manera empírica o espontánea" (GAINZA, 2002, p. 52 e 53).

7 "[...] we must encourage and assist the children to think critically and creatively [...]. Children should be encouraged to: (i) discuss what it is that is intrinsic to their own musical experience" (BURNARD, 2000, p. 21).
} 
a harpa e o teclado do piano e tem personagens e uma história. A última é executada no teclado do piano e o foco são as formas de notação musical com que o aluno registrou sua composição;

- que as crianças estivessem em fases similares de domínio do instrumento. As músicas selecionadas foram criadas pelos alunos em seu primeiro ano de estudo. Embora cada um tenha se desenvolvido de maneira diferente, pois respeitou-se sua singularidade, todos já haviam trabalhado as seguintes propostas: explorar sonoramente o piano, tocar músicas de ouvido, por imitação e por leitura (não convencional e convencional), improvisar, registrar suas músicas com notação não convencional, aproximar-se da escrita tradicional e tocar músicas a quatro mãos.

\section{A escolha metodológica}

Para escolher a metodologia mais apropriada, considerei diversos aspectos da pesquisa: objetivo; características do material selecionado; o foco no campo da criação e da educação; participação de investigador e investigados já que são meus alunos e um dos objetos de estudo foi realizado a quatro mãos; busca da compreensão de cada caso em si, sem comparações; análises feitas a partir da visão das crianças e de minhas interpretações sobre seu processo criativo; técnica descritiva.

Depois de analisá-los, considerei que a opção mais apropriada seria a pesquisa qualitativa. Para validar essa escolha, apresento a definição de Stake (2011):

Talvez as diferenças metodológicas mais importantes entre qualitativo e quantitativo sejam duplas: a diferença entre (1) tentar explicar e (2) tentar compreender e a diferença entre (1) um papel pessoal e (2) um papel impessoal para o pesquisador [...]. Para a pesquisa qualitativa, como indicado anteriormente, o próprio pesquisador é um instrumento ao observar as ações e contextos e, com frequência, ao desempenhar intencionalmente uma função subjetiva no estudo, utilizando uma experiência pessoal em fazer interpretações (STAKE, 2011, p. 30).

Também identifiquei na pesquisa desta dissertação características elencadas por Bresler (2007, p. 11-12), e destaco aqui as mais relevantes para este contexto:

1. [É] contextual e holística [...].

2. Envolve perspectivas múltiplas de participantes situados em lugares diferentes.

3. É tipicamente dirigida para um caso [...]. É relativamente não comparativa, porque busca entender um caso e não entender como esse caso difere de outros [...]. 
4. É empírica e dirigida para um campo, sendo o campo o local onde acontece o caso a ser investigado [...].

5. Envolve compromisso prolongado com os campos de pesquisa [...].

6. É descritiva. Há uma preferência pela descrição usando linguagem natural [...].

7. É interpretativa e empática. A pesquisa qualitativa está preocupada com os diferentes significados que ações e eventos adquirem para diferentes pessoas, suas referências, seus valores, prestando atenção às intenções daqueles que são observados. Há uma tentativa de capturar as perspectivas e as percepções dos participantes, junto com a interpretação do investigador.

8. O investigador é o instrumento fundamental. Objetividade é impossível por definição, já que o investigador está sempre situado. As subjetividades compromissos, valores, crenças - deveriam ser reconhecidas ao invés de suprimidas.

Na pesquisa qualitativa, optei pelo relato de experiência, especificado por Fernandes (2013). Considerei essa modalidade a mais adequada, pois esta dissertação prioriza "a descrição e análise de uma prática de ensino de música desenvolvido pelo próprio autor do trabalho" (FERNANDES, 2013, p. 214-215), apresentando fundamentação teórica para essa prática. Outro aspecto deste trabalho é a intenção de compreender melhor o contexto em que os alunos compuseram suas músicas e as práticas pedagógicas implícitas nesse processo, buscando aprimorar minha própria prática e contribuir para a discussão sobre o espaço da criação no ensino de piano. Conforme Fernandes:

No relato de experiência, as descrições práticas devem enriquecer a discussão teórica, uma vez que apresenta a própria vivência profissional ou pessoal do autor, sem a formalidade de enquadrar conteúdo numa metodologia de estudo de caso ou de pesquisa-ação. [...] Assim, há no relato de experiência uma realimentação, ou seja a teoria alimentando a prática e a prática ilustrando a teoria (FERNANDES, 2013, p. 216).

Apesar de Fernandes apontar diversas semelhanças e poucas diferenças entre as modalidades de pesquisa-ação e relato de experiência, pude verificar na minha pesquisa que um diferencial do relato de experiência é que esse abarca uma descrição "mais informal e sem rigor obrigatório da apresentação de resultados da pesquisa" (FERNANDES, 2013, p. 215). Assim, considero que essa opção metodológica contempla os objetivos e o próprio texto desta dissertação. 


\title{
CAPÍTULO 1
}

\section{Ensino e aprendizagem de piano}

\author{
Sabemos que é necessário libertar a educação e o ensino \\ artísticos de métodos obtusos, que ainda oprimem os nossos \\ jovens e esmagam, neles, o que possuem de melhor. A fadiga e \\ a monotonia de exercícios conduzem à mecanização tanto dos \\ professores quanto dos discípulos. [...] é indispensável que em \\ todo o ensino artístico se sinta o alento da criação.
}

Koellreutter

Ao longo dos 30 anos de minha prática em aulas de piano, sempre fiz pesquisa informal de métodos, livros didáticos, estudos e peças musicais, mesmo que com uma sistematização não acadêmica. Apesar de a extensa revisão bibliográfica dos métodos adotados no decorrer da história do ensino de piano no Brasil não ser o objeto de pesquisa desta dissertação, considero relevante dar uma visão geral, para contextualizar o maior ou menor espaço da criação no ensino do piano - esta, sim, o foco da pesquisa. Assim, apresento um breve painel da história do ensino de piano no Brasil a partir do século XIX, discorro sobre o pensamento musical que orientou a maioria dos métodos de iniciação e destaco alguns livros e métodos diferenciados por uma abordagem mais criativa, apontando seus princípios básicos e a forma de sua organização.

No Brasil, a história do ensino de piano começou a ser construída após a chegada da corte de D. João VI, em 1808. Antes disso, havia o ensino musical formal no Brasil Colônia desde o século XVI, com os jesuítas. No século XVIII, sempre a cargo da Igreja, a formação musical estava centralizada nos professores de música de irmandades como a conhecida Irmandade de Santa Cecília do Rio de Janeiro, com sede em Lisboa. A vida musical da Colônia era modesta, com exceção das cidades da capitania de Minas Gerais, que viveu uma fase áurea no final do século XVII.

Com a vinda da Família Real, houve uma significativa mudança na vida musical e artística brasileira. Amante da música, D. João VI reorganizou a Capela Real trazendo muitos artistas e músicos e fomentando atividades musicais tanto religiosas como profanas (MARIZ, 2000, p. 51), e teve início um período de uma vida musical agitada: efervescente durante a estada de D. João VI, um certo declínio no Primeiro Império - em consequência de grandes 
problemas financeiros, embora D. Pedro I também fosse entusiasta da música e até compositor - e uma revigorização no Segundo Reinado.

De modo geral, a chegada da corte portuguesa ensejou a inauguração de teatros e bibliotecas, a promoção de muitos concertos, a oficialização do ensino de música nas escolas, a abertura de concurso público para contratação de professores de música e o aumento do número de professores particulares de instrumento, em especial, o piano.

Em meio a essa efervescência musical, o piano foi-se destacando na sociedade brasileira como instrumento não só preferido, mas obrigatório em toda família mais abastada, sobretudo para as "donzelas”, como confirma a pesquisadora Maria Francisca Paez Junqueira: "Não há dúvida alguma de que o estudo do piano e o domínio da língua francesa surgiram como valores elitizantes indispensáveis às famílias tradicionais e abastadas" (JUNQUEIRA, 1982, p. 12). No Brasil Império, como forma de status, a elite cultuava tudo o que se relacionava aos costumes europeus, e o piano tornou-se um símbolo dessa condição.

De acordo com Rita de Cássia Fucci Amato, maestrina e pesquisadora, "a abertura dos portos às nações amigas [de Portugal], ainda em 1808, e os Tratados de 1810, firmados com a Inglaterra, ao abrir comercialmente o mercado brasileiro aos produtos ingleses, permitiram um impulso à importação de pianos" (AMATO, 2008, p. 168, grifos do original), o que concorreu sobremaneira para a crescente preferência do instrumento pela elite brasileira da época, impulsionando o desenvolvimento de uma cultura pianística que persistiu durante todo o século XIX e até mais da metade do século XX. Em 1856, o crítico e escritor Manuel de Araújo Porto Alegre citou o Rio de Janeiro como "a cidade dos pianos" (SCHLOCHAUER, 1992, p. 72). Mais tarde, em 1922, o também musicólogo Mário de Andrade, já no título de seu artigo na revista Klaxon - "Pianolatria" -, apontava uma verdadeira obsessão pelo instrumento, principalmente em São Paulo:

[...] Dizer musica, em Sâo Paulo, quási significa dizer piano. Qualquer audição de alunos de piano enche salões.. Qualquer pianista estrangeiro tem aqui acolhida incondicional... [...] Mas qual! ha uma fada perniciosa na cidade que a cada infante dá como primeiro presente um piano e como único destino tocar valsas de Chopín!... (ANDRADE, 1922, p. 8).

Segundo a pianista brasileira Regina Schlochauer, uma crescente profissionalização de professores de música começou a acontecer a partir de 1830, inclusive com a chegada de músicos profissionais com formação didática como Rafael Machado Coelho (1814-1887), 
Pierre Guigon (1803-1862) e Antonio Tornaghi (século XIX) (SCHLOCHAUER, 1992, p.7475). Amato (2008, p. 169) também destaca a importância da chegada, na segunda metade do século, de dois músicos estrangeiros: Arthur Napoleão (1843-1925), pianista português que, com Leopoldo Miguez (1850-1902), fundou no Rio de Janeiro a conhecida editora e casa de pianos e partituras Casa Artur Napoleão, e Luigi Chiafarelli (1856-1923), considerado o primeiro a estruturar uma educação pianística em São Paulo, contribuindo para o reconhecimento da cidade como destacado centro musical do país.

Ainda no Segundo Reinado, em 1841, Francisco Manuel da Silva - autor do Hino Nacional Brasileiro - fundou o Conservatório Imperial, no Rio de Janeiro. Em 1906, já na era do café, em São Paulo, funda-se o Conservatório Dramático e Musical de São Paulo. Nas primeiras décadas do século $\mathrm{XX}$, diversos conservatórios foram inaugurados pelo país, tendo os dois primeiros como modelo. Amato se refere a esse momento da seguinte forma:

Os conservatórios musicais e a cultura pianística tiveram - entre a segunda
metade do século XIX e os anos de 1960, aproximadamente - uma
importância notável na sociedade brasileira, com ampla generalização de
suas práticas, principalmente pelo centro-sul do país. [...] a deflagração dos
conservatórios musicais pelo país, os quais receberam um bom acolhimento
por parte da população, principalmente das classes média e alta, que, naquele
contexto sociocultural, valorizavam veementemente a cultura europeizada,
tida ao mesmo tempo como símbolo de "bom gosto" e como um resgate de
suas práticas, no caso dos imigrantes. Assim, o interior do estado de São
Paulo passou a abrigar, a partir dos anos de 1930 e 40, um grande número
dessas instituições educativo-musicais (AMATO, 2008, p. 175-176).

Os princípios pedagógico-musicais que fundamentaram o ensino de piano no Brasil, seja nos conservatórios ou em aulas particulares, foram totalmente inspirados nos conservatórios europeus dos séculos XVIII e XIX, que tiveram como modelo o Conservatoire National de Musique, atual Conservatório de Paris. A educadora musical Neide Esperidião (2012, p. 171), autora do livro Educação musical e formação de professores: suíte e variações sobre o tema, aborda o histórico dos conservatórios e indica seus fundamentos comuns: ensino técnico-instrumental, virtuosismo e habilidades performáticas. Essa orientação foi seguida por todos os conservatórios brasileiros, desde os primeiros. Um exemplo disso são os do estado de São Paulo, padronizados e fiscalizados pelo Conselho de Orientação Artística de São Paulo (COA) e cujos currículos seguiam obrigatoriamente o modelo do Plano Padrão, elaborado por Samuel Archanjo dos Santos (ESPERIDIÃO, 2003, p. 185). 
Exceto por poucas adaptações, a referência direta do Plano Padrão era o programa do Instituto Nacional de Música do Rio de Janeiro (de 1890), que, por sua vez, pouco diferia do currículo adotado na sua inauguração (de 1848), como Conservatório Imperial, com orientação pedagógica pautada no Conservatório de Paris. Assim, pedagogicamente, pouca coisa havia mudado desde 1795, data da criação do então Conservatoire National de Musique (AMATO, 2006).

Sobre o ensino de piano no Brasil, Ana Lúcia Gaborim Moreira, pianista e educadora musical, afirma que, pelo menos até a década de 1930, os métodos adotados eram os europeus, que tinham como principal conteúdo peças organizadas em certa graduação de dificuldade, leitura musical em duas claves de sol em oitavas, melodias majoritariamente na tonalidade de Dó Maior e, por consequência, o uso apenas das teclas brancas em quase todo o livro (MOREIRA, 2005, p. 68). Com pequenas diferenças, os principais métodos aplicados eram os dos seguintes autores: A. Schmoll, Francisco Russo e Margareth Steward, cujo método apresentou algumas inovações, mas era ainda pautado totalmente na leitura e na progressão técnica. Essa orientação pedagógica permaneceu basicamente a mesma durante todo o século XX, apresentando pequenas mudanças, porém não estruturais, na maioria dos contextos de ensino de piano.

Nas últimas décadas, educadores musicais, pesquisadores e pianistas como Amato (2006), Brito (2007), Campos (2000), Corvisier (2009), Esperidião (2003) e Fonterrada (2003) têm apontado essa permanência do ensino tradicional na educação musical brasileira, especialmente na educação pianística, evidenciando uma abordagem tecnicista, pautada exclusivamente em exercícios técnicos, aquisição da leitura tradicional e interpretação de obras de um repertório delimitado, quase sempre, entre o Barroco e as primeiras produções do século XX. Segundo Amato (2006, p. 76), essa pedagogia tecnicista, que apresenta as figuras do professor e do aluno com funções bem definidas - o professor deve transmitir o conhecimento, o aluno deve desenvolver as habilidades para uma execução instrumental satisfatória -, não pode ser considerada um ensino criativo. Moema Craveiro Campos, pianista, compositora e professora goiana, elucida essa pedagogia.

$\mathrm{Na}$ verdade, o ensino tradicional de piano tem-se direcionado apenas à interpretação musical de repertório. Há no ar um sentimento de frustação nos estudantes de piano, quando, após longos anos de trabalho no instrumento, sentem-se incapazes de tocar uma canção popular "tirada de ouvido", acompanhar o canto dos amigos numa reunião informal ou se soltar numa improvisação musical [...]. 
No aspecto geral da educação musical através do piano, ler música, tocar sem errar, passa a ser o objetivo maior do estudante-pianista. A oportunidade de livre expressão, de observação e percepção é comumente deixada de lado ou para segundo plano [...] Quase não temos o direito de nos expressar pesquisando nossa capacidade criativa ao improvisar, ao explorar os sons do piano inventando algo apenas nosso, do jeito que gostamos, jamais ouvido antes [...] (CAMPOS, 2000, p. xxi/4).

Em contrapartida, Moreira (2005, p. 165) afirma que a educação pianística está se transformando e que coexistem diversas práticas de ensino musical, discordando da ideia de que os paradigmas do século XIX teriam sido unanimemente mantidos. Segundo a autora, estamos vivendo um momento de questionamentos e reflexões. No entanto, na mesma pesquisa, ela menciona casos em que ainda vigora a prática do ensino tradicional.

Durante a pesquisa, em alguns casos, constatou-se que a aula de piano se limita ao desenvolvimento da habilidade de leitura, podendo concentrar-se exclusivamente no "método" ou adotando materiais complementares - peças avulsas e a quatro mãos, livros com exercícios de técnica e até mesmo peças do repertório popular - com o mesmo propósito. Em geral, as professoras que adotam essa postura seguem praticando o ensino tal como o receberam, o que, segundo as reflexões apresentadas ao longo do trabalho, pode ser uma das causas de desinteresse dos alunos e, consequentemente, de evasão do curso, uma vez que o objetivo do ensino continua sendo a formação de concertistas (MOREIRA, 2005, p. 166).

Faz-se importante destacar que muitos professores mantiveram-se alheios às transformações que ocorreram tanto no campo da composição, como na própria educação musical, concorrendo para a permanência do ensino tradicional de piano em diversos contextos educacionais do país, ainda nos dias de hoje. Nas primeiras décadas do século XX, na Europa, floresceram novas concepções de ensino musical, extremamente importantes para a construção de uma educação musical no Ocidente. Inspirados pelas grandes transformações científicas e artísticas da época, os chamados métodos ativos trouxeram uma nova visão da criança e das formas de iniciá-la na linguagem musical, enfatizando a experiência antes da compreensão intelectual, com participação ativa do aluno em vivências corporais, auditivas e de canto. Destacam-se Émile-Jacques Dalcroze (1865-1950), Edgar Willems (1890-1978), Zoltán Kodály (1882-1967), Carl Orff (1895-1982) como principais expoentes desses métodos, alguns dos quais, segundo a educadora musical Marisa Fonterrada (2005, p. 107108), não podem ser chamados de métodos, mas sim de abordagens. Tendo chegado ao Brasil em meados da década de 1950, essas propostas foram esquecidas ou restritas a segmentos específicos, devido a condições históricas diversas e principalmente à exclusão da disciplina de música do currículo oficial, em 1971 (LDB n. 5.692/1971). 
Apesar de essas abordagens não terem alcançado uma dimensão mais ampla, como esclarece Fonterrada (2005), é possível verificar algumas influências desse novo olhar para a educação musical no cenário brasileiro. No que tange à pedagogia pianística, é importante mencionar a atuação do pianista e professor Antônio de Sá Pereira (1888-1966). Influenciado pelas ideias do psicólogo suíço Édouard Claparède e do filósofo e pedagogo estadunidense John Dewey, assim como pelos educadores musicais dos métodos ativos, Sá Pereira deixou inúmeras contribuições, a começar pela criação do "Curso de Pedagogia Musical, especialmente de Piano" no Instituto Nacional de Música, no Rio de Janeiro. Ele também foi o primeiro a difundir as ideias da escola moderna de piano - cujos principais representantes eram Cortot (1877-1962), Marmontel (1816-1898) e Leimer (1858-1944) -, publicando $O$ ensino moderno de piano: aprendizagem racionalizada, em 1933. É interessante notar que as ideias de Sá Pereira já eram diferenciadas do ensino tradicional, apontando uma nova abordagem para o ensino de piano.

A pianista e professora Fátima Corvisier discute a pedagogia de Sá Pereira destacando os aspectos inovadores para a época: a formação do músico, e não apenas do pianista, a prioridade à musicalização antes do ensino da técnica, a importância de uma relação direta entre os estudos teóricos e a prática pianística, a constituição do solfejo como estudo fundamental e a necessidade do planejamento de um estudo de qualidade, e não só do número de horas (CORVISIER, 2009, p. 256-257).

Assim como as de outros professores seguidores da escola moderna, as ideias de Sá Pereira se destacaram e foram um avanço em relação aos métodos tradicionais adotados anteriormente. Contudo, ainda se concentravam na leitura como uma primeira etapa do desenvolvimento musical do aluno. É fato também que, ao lado das inovações pedagógicas difundidas pelo pianista, nas aulas de piano de muitos professores particulares e em diversos conservatórios brasileiros ainda prevalecia um ensino calcado em referências pedagógicas do século XIX. Também é importante lembrar que o espaço da pesquisa sonora no instrumento e mesmo da criação não eram garantidos na proposta de Sá Pereira, assim como nas outras publicações da época, porque ele não viveu a tempo de presenciar o novo pensamento pedagógico musical que começou a surgir por volta da década de 1960, que contemplava esses aspectos e que só chegou ao Brasil por volta dos anos 1980. 
A partir da década de 1960, um segundo momento importante da educação musical despontava na Europa e na América do Norte, deflagrado por compositores como os ingleses George Self (1921-1967), John Paynter (1931-2010) e Brian Dennis (1941-1998), o italiano Boris Porena (1927- ) e o canadense Murray Schafer (1933- ). Estes músicos mudaram o foco do processo educativo musical, enfatizando a criatividade, o som como fonte de exploração e a aproximação entre a música de vanguarda e a sala de aula. Seu pensamento só começou a ser conhecido entre os educadores musicais brasileiros entre 1980 e 1990. Murray Schafer é o mais difundido no Brasil, tendo sido introduzido no país por Marisa Fonterrada, que traduziu alguns de seus livros, escreveu artigos sobre sua obra e esteve à frente da organização de diversos workshops ministrados por ele ao longo das últimas décadas.

Ainda nos anos 1960, chegavam ao Brasil métodos estadunidenses para piano, muitos deles bastante utilizados até hoje. Os autores eram: John Thompson, Michael Aaron e Leila Fletcher. É importante citar que esses livros foram importados cerca de 30 anos depois de sua publicação original, no final da década de 1930, nos Estados Unidos, o que explica a distância entre seus princípios metodológicos e a nova concepção pedagógica que vinha movimentando a educação musical da época. Apesar disso, a abordagem desses autores era bastante distinta da dos primeiros métodos adotados no Brasil, apresentando como principais diferenças a leitura nas duas claves desde o início, o movimento contrário a partir do dó central e um repertório composto por diversas canções folclóricas. Apesar de ser inovador introduzir o folclore na iniciação ao piano, as melodias, por serem estadunidenses, não eram conhecidas pelas crianças brasileiras e não alcançavam o impacto pretendido pelos autores.

Como já mencionado, apesar de trazerem mudanças, os métodos importados ainda tinham a leitura como porta de entrada da iniciação musical no piano, e a criação e a exploração sonora do instrumento não faziam parte da orientação metodológica desses autores. Entre as décadas de 1950 e 1970, alguns pianistas brasileiros começaram a publicar livros didáticos com os mesmos princípios e, às vezes, até com alguma inovação, mas sem mudanças realmente significativas. Como exemplo de algumas dessas publicações, podem-se citar: Maria Aparecida Vianna e Carmen Xavier (1953), Heitor Alimonda (1967) e Alice Botelho (1976), entre outros (MOREIRA, 2005, p. 72-73).

Em meados da década de 1950, uma outra série de livros didáticos estadunidenses surgiu, apresentando maior abertura à participação do aluno com propostas de invenção, de tocar de ouvido, de transposição e de usar as teclas pretas e com uma linguagem mais 
próxima da música popular. Dessas publicações, destaco: Time to Begin (1955), da coletânea Music Tree de Frances Clark, Louise Goss e Sam Holland, e a série Music for Piano (1960), de Robert Pace. Alguns dos livros do método Pace foram traduzidos para o português e publicados pela primeira vez no Brasil em 1973.

Entre os anos 1960 e 1990, podem-se destacar algumas publicações brasileiras com abordagens mais alinhadas às mudanças do cenário pedagógico-musical da época, incluindo: propostas de improvisações, melodias atonais e modais, notação contemporânea, mudanças de compasso, transposição e outras possibilidades de musicalização no piano. Cada uma delas enfatizou um ou mais desses aspectos. Algumas delas são: Ludus Brasiliensis (1966), do compositor Ernst Widmer, Sons da infância (1979), de Marisa Fonterrada e Maria Lúcia Pascoal, Iniciação ao piano (1985), de Carmem Maria Mettig Rocha, e Nossos dez dedinhos (1994), de Elvira Drummond (MOREIRA, 2005, p. 72-78). Infelizmente, esses livros não foram difundidos como os estadunidenses, até hoje muito utilizados apesar de não garantirem espaço para a criação.

A partir da década de 1970, na Europa e na América do Norte, surgiram publicações voltadas à iniciação ao piano que abordavam o espaço da criação e o "tocar de ouvido", afastavam-se da posição do dó central, incluíam uma prenotação e, algumas, até mesmo a notação contemporânea. Delas, citamos: Piano Discovery (1983), da série Music Pathways (1972), de Lynn Olson, Louise Bianchi e Marvin Blickenstaff; Music Moves for Piano, uma série de livros de Marilyn Lowe; a publicação húngara dos oito volumes do Játékok (a partir de 1979), do compositor e professor György Kurtág; os livros alemães Klavierschule für Anfänger (1982), do pianista alemão Harald Bojé, e Europäische Klavierschule (entre 1992 e 1994), de Fritz Emonts; e mesmo o australiano Simply Music piano method, de Neil Moore. Nenhuma dessas obras foi publicada no Brasil.

Nas décadas citadas, os métodos mais adotados no país não se aproximavam de livros didáticos, pesquisas e propostas - já bem estruturadas - de outros países da América Latina.

[...] existe um corpo considerável de propostas em educação musical em países latino-americanos, como México (Cesar Tort), Argentina (Violeta Gainza, Judith Akoschky, Silvia Malbrán, Silvia Furnó, entre outros), Venezuela (Programa Nacional de Orquestras), Colômbia (Programa Nacional de Educação Musical nas Escolas), Costa Rica (Programa Nacional de Orquestras) [...] ao considerá-los, o Brasil avançará na questão do estabelecimento do perfil de sua educação musical, delineando melhor sua identidade (FONTERRADA, 2005, p. 189). 
Embora a autora se refira a propostas no âmbito da educação musical como um todo, é possível considerar essa afirmação especificamente para o ensino de piano. Dentre os educadores citados, Violeta Hemsy de Gainza - pianista argentina, educadora musical e autora de muitos títulos de educação musical - é a mais conhecida dos brasileiros, principalmente por visitar o país constantemente, ministrando cursos e palestras e dando entrevistas. Apenas um de seus livros foi traduzido para o português, outros circulam entre diversos educadores musicais no original, em espanhol. Gainza publicou um vasto material para o ensino de piano, incluindo coletâneas de composições de alunos. Palitos chineses e Método para piano são conhecidos entre professores que buscam uma abordagem mais contemporânea, mas não são encontrados facilmente nem em lojas especializadas. Palitos chineses apresenta composições de alunos, melodias sem grandes dificuldades técnicas e que podem ser tocadas apenas com os dedos indicadores (daí o nome palitos chineses), incentiva o uso das teclas pretas desde o início do contato com o piano, e se utiliza de dois tipos de escrita: a tradicional e uma não convencional, com o desenho do teclado e teclas numeradas. A proposta do livro é bem diferenciada, mas não tem a intenção de constituir-se como método. Método para piano tem três volumes nos quais, progressivamente, a autora propõe um trabalho musical com as estruturas básicas, abrindo espaço para uma prática reflexiva e para a invenção.

Por volta da década de 1980, passamos a viver um terceiro momento da educação musical, que "se caracteriza por tender a reforçar a integração e a autonomia dos processos criativos e conscientes na aprendizagem" (GAINZA, 2002, p. 67, tradução nossa, grifos do original). A autora destaca que vivemos uma crise na educação musical e que, para superá-la, os docentes devem construir um conhecimento profundo de suas bases filosóficas, psicológicas, pedagógicas e sociais. A prática deve estar presente, integrando as principais contribuições de cada um dos três momentos (ou três gerações) da educação musical: o movimento, a criatividade e a consciência.

Mesmo diante da constatação de que diversos professores e instituições ainda mantêm as orientações tradicionais de ensino de piano, esses novos paradigmas do pensamento pedagógico-musical têm ocupado o cenário da educação musical brasileira, sendo tema de congressos, seminários, artigos etc. (AMATO, 2008; CAMPOS, 2000; ESPERIDIÃO, 2012; MONTANDON, 1992; MOREIRA, 2005). Propostas pedagógicas pianísticas brasileiras vêm

\footnotetext{
8 “[...] se caracteriza por tender reforzar la integración y autonomía de los procesos creativos y conscientes en el aprendizaje" (GAINZA, 2002, p. 67).
} 
surgindo gradualmente; nelas, a leitura não é mais o objetivo primeiro do estudo do instrumento: considera-se o prazer do aluno na escolha do repertório, se o estimula a tocar de ouvido e se valoriza o espaço para a criação e a aquisição do conhecimento de forma consciente.

Podem-se citar alguns materiais para piano com essa nova abordagem, publicados entre a década de 1990 e os dias atuais: Educação musical através do teclado (1989), de Maria de Lourdes Junqueira Gonçalves e Cacilda Borges Barbosa, Atenção! Crianças compondo (1993), de Fernanda Fontoura, Piano 1 (2001) e Piano 2 - Arranjos e atividades (2009), de Ana Consuelo Ramos e Gislene Marino, Divertimentos (2003), de Laura Longo.

Partindo da referência de Moreira (2005) e de informações dadas informalmente por colegas professores de piano, é importante citar também publicações com ênfase em música popular brasileira, harmonia aplicada e criação de arranjos, entre elas: os 3 volumes de Método de arranjo e repertório e os 2 volumes de Iniciação ao piano, da pianista e professora Rosana Giosa, e os diversos livros de Antonio Adolfo, pianista e educador.

Com o intuito de me debruçar um pouco mais sobre os materiais que oferecem possibilidades para a criação no processo de ensino e aprendizagem do piano e reafirmar a importância do alinhamento dos professores com as novas orientações pedagógicas da educação musical, selecionei onze livros para analisar mais detalhadamente suas propostas. Para contextualizá-los, apresento uma síntese de cada livro e um verbete biográfico de cada autor. Adotei o critério cronológico direto.

\section{Music for Piano - Robert Pace}

Verbete biográfico: Robert Pace foi pianista concertista, educador e autor de livros para piano traduzidos para várias línguas e, ainda hoje, distribuídos em muitos países. Criou o método Pace de ensino de piano, que conta com um centro de formação de professores.

Nasceu na cidade de Newton, em Kansas, no ano de 1922, e faleceu em 2010, também nos Estados Unidos. Graduou-se na Juilliard School, reconhecida escola de música e artes cênicas de Nova Iorque, sendo aluno dos renomados professores Joseph e Rosina Lhévinne. Fez mestrado e doutorado na Teachers College, Columbia University. Mais tarde, lecionou 
nas instituições em que estudou e, em 1969, tornou-se diretor do Departamento de Música da Universidade de Columbia.

Robert Pace teve uma atuação ativa na educação musical estadunidense, estando à frente de diversos projetos e ocupando cargos importantes como a cadeira de piano na Music Educators National Conference, de 1953 a 1956. Em 1963, criou e dirigiu a National Piano Foundation até 1977, quando se tornou diretor-executivo da International Piano Teaching Foundation. Desde então até seu falecimento, participou de consultorias, seminários e congressos em vários países.

Pace começou a desenvolver as ideias que fundamentaram seu método logo que se formou na Julliard e começou a lecionar, e "embora cada professor imprima sua interpretação pessoal ao método, os principais pontos do Método Pace devem estar representados" (LOVINSON, 2014, tradução nossa), são eles:

1. Ensinar conceitos musicais. $O$ autor define que conceitos são ideias amplas que podem ser aplicadas a cada nova situação, expandindo-se e aprofundando-se de acordo com o desenvolvimento do aluno. Um dos exemplos citados é o conceito de melodia, apresentado da seguinte forma: "a música pode 'subir' ou 'descer', ou ficar no mesmo lugar" (LOVINSON, 2014).

2. Aula em grupo. Pace defende o aprendizado de piano em grupo, pois acredita que, quando num ambiente de cooperação, os estudantes podem aprender uns com os outros tão bem quanto com o professor.

3. Criatividade. Fazer do estudo de música um processo criativo.

4. Pensamento analítico. Ensinar os alunos a solucionar problemas a partir da avaliação da própria prática, isto é, identificar o problema, pensar numa estratégia, solucioná-lo rapidamente e analisar os resultados.

5. Musicalidade ampla. Desenvolver as diversas habilidades musicais - técnica, leitura, treinamento auditivo, conhecimento teórico e improvisação - de forma simultânea e interligada, a partir do repertório que o aluno está estudando. 


\section{Os livros do método Pace}

A partir dos princípios citados anteriormente, Pace criou uma série de 5 livros para piano, com progressão de dificuldade. Cada um dos livros tem 4 volumes; Music for Piano book 1, por exemplo, é acompanhado de Creative Music 1, Theory Papers 1 e Finger Building 1. A série foi publicada em 1960, nos Estados Unidos, porém sua primeira publicação no Brasil foi só em 1973.

Os quatro livros de cada número são interligados, e os mesmos conteúdos são apresentados de acordo com o objetivo de cada livro.

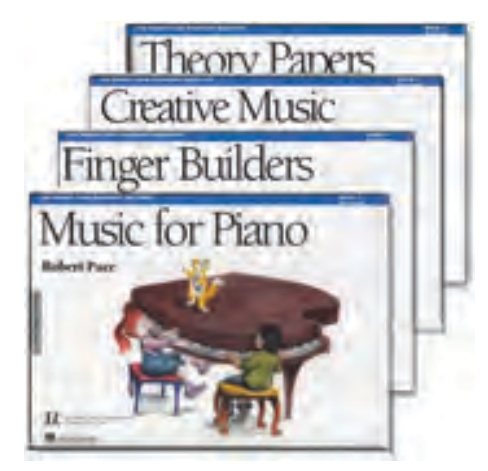

No Music for Piano-book one, ${ }^{9}$ as primeiras músicas a ser estudadas estão apresentadas em notação não convencional. Pace desenha um teclado e indica o número dos dedos sobre as teclas desenhadas. Ao lado do teclado, ele também escreve o número dos dedos, mas em linhas ascendentes, desenhando o perfil melódico da música, assim introduzindo a relação audiovisual.

\footnotetext{
${ }^{9}$ Nesta dissertação, usamos o livro traduzido: Pace, R. Música para piano. Livro 1. São Paulo: Ricordi, 1973.
} 


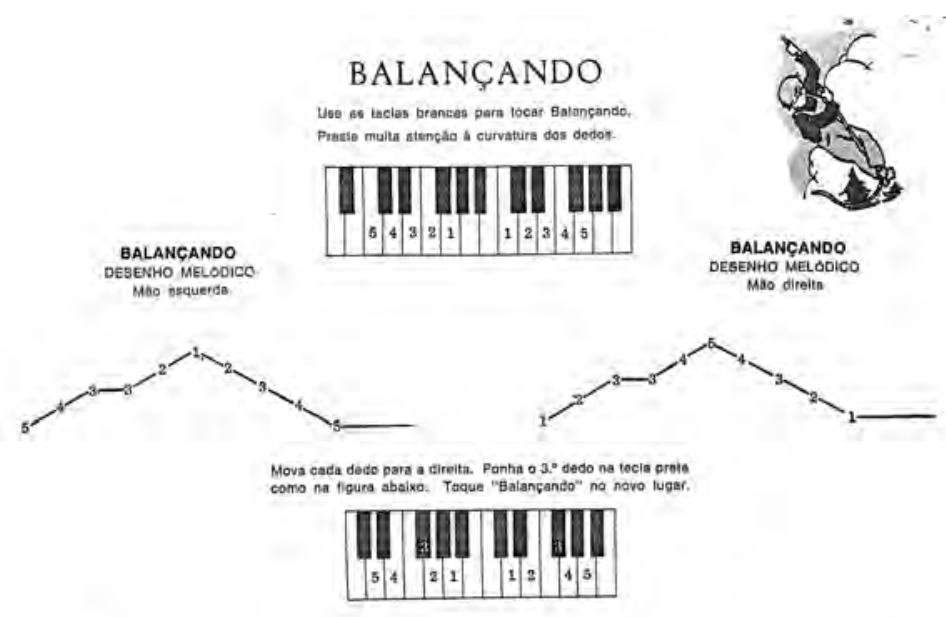

Mis esquetar Tônico do Protessar

Mas diratia

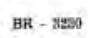

Nas páginas seguintes, apresenta o pentagrama, para que as melodias já estudadas sejam lidas na escrita tradicional. As melodias são tocadas nas teclas brancas e pretas, em diversas tonalidades, denotando a preocupação de introduzir os conceitos de tonalidade e transposição a partir da prática e desde o começo do estudo de piano.

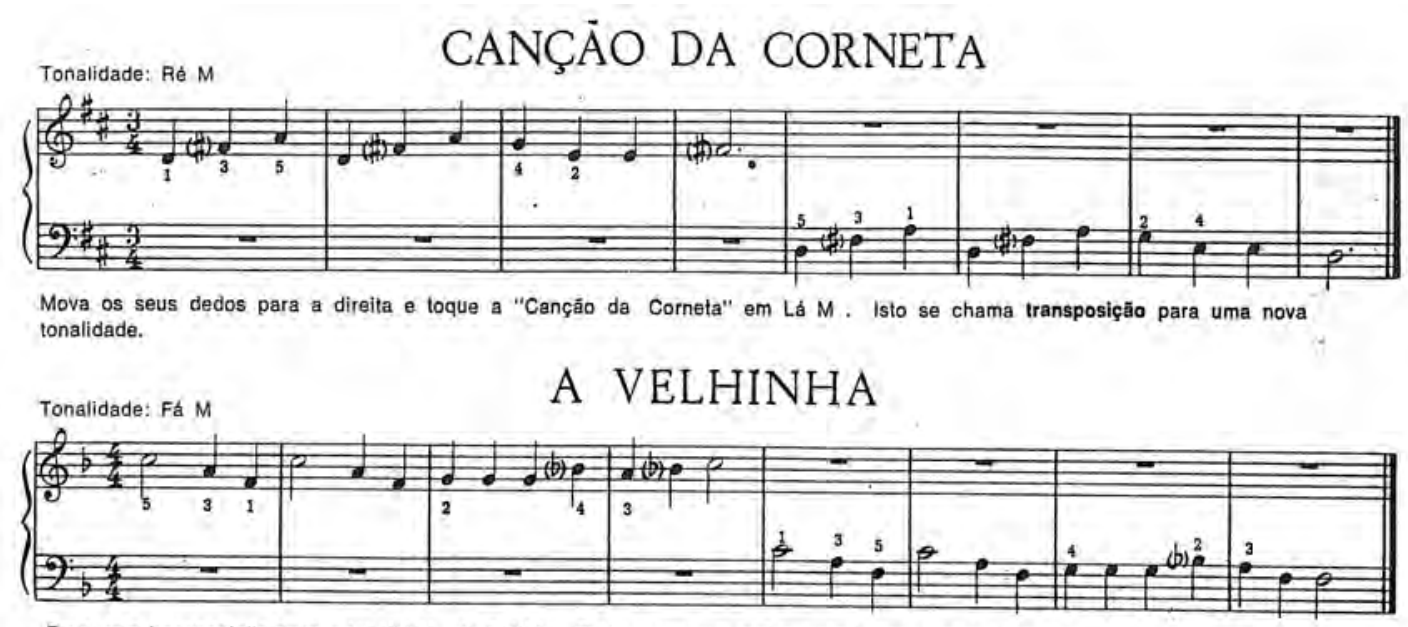

Faça uma transposição para a tonalidade de Sol M. Todos os seus dedos estarâo nas teclas brancas.

No livro Creative Music, Pace propõe que o aluno crie variações sobre um tema, uma frase como "resposta" a uma "pergunta" e improvisações sobre cadências harmônicas básicas.

Em Theory Papers, os conceitos musicais presentes no volume correspondente são abordados. Como exemplo, nos diversos volumes, o autor propõe desde exercícios de 
localização de notas no teclado, leitura no pentagrama até o conceito de tonalidades e armação de claves, formação de tríades, cadências etc.

No Finger Builders, o foco é o desenvolvimento de habilidades técnicas. Os exercícios trabalham coordenação, posição adequada de dedos e mãos, agilidade etc.

Ao analisar os livros de Pace, nota-se a clara intenção de desenvolver uma formação pianística baseada em processos criativos, porém somente dentro do sistema tonal. Em seu método, não há propostas de criação que aproximem o aluno da chamada música erudita contemporânea à época, isto é, a música da segunda metade do século XX. Como autor estadunidense, parece-me que ele criou um método que incentiva o processo criativo, porém estava especialmente preocupado com o conhecimento harmônico - como a transposição para várias tonalidades e a formação de acordes para acompanhar melodias -, o que era muito bem-vindo para instrumentistas pop e de jazz.

Ao considerar os autores de métodos estadunidenses frequentemente adotados na educação pianística brasileira - Leila Fletcher, John Thompson, e, mais recentemente, Hal Leonard -, o Método para Piano de Robert Pace se destaca em relação ao espaço para a criação, inexistente nos outros. Contudo, é importante ressaltar que as propostas criativas apresentadas têm limitações, se considerarmos a criatividade no piano a partir de concepções mais amplas e atuais.

\section{Ludus brasiliensis - Ernest Widmer}

Verbete biográfico: Ernest Widmer, suíço naturalizado brasileiro em 1967, destacouse no panorama musical brasileiro da segunda metade do século XX. Pianista, compositor e regente, também foi professor e diretor da Escola de Música da Universidade Federal da Bahia, estado onde viveu desde que chegou ao Brasil, em 1956. Publicou muitas obras musicais, entre elas Ludus Brasiliensis, uma coleção de livros para iniciação ao piano.

Widmer nasceu em 1927, em Aarau, na Suíça, onde também faleceu, em 1990. Estudou música desde a infância e, segundo ele, "aos quatorze anos já havia percebido que 
tinha uma conexão com música"10 (WIDMER [...], tradução nossa). Começou a estudar piano, teoria e harmonia com Otto Kuhn e, já nessa época, ensaiou suas primeiras composições. Mais tarde, na graduação, estudou com importantes músicos suíços da época como Paul Müller (regência), Ernst Hörler (canto) e Rudolf Wittelsbach (análise). Foi fortemente influenciado pela pedagogia de Willy Burkhard, com quem estudou contraponto e composição, e por Walter Frey, professor de piano que lhe apresentou a música moderna do século XX. Diplomou-se em 1950 e, por seis anos, foi regente de coro da igreja de Aarau, professor e regente coral na faculdade e professor particular de piano (WIDMER [...]).

Apesar de compor desde adolescente, Fünf Lieder im alten Stil, composta em 1949, é considerada Opus 1. Desde então, compôs obras para coro, conjuntos instrumentais e instrumentos solo, lied e música para a rádio DRS. Leonardo Loureiro Winter, músico e pesquisador, divide a carreira composicional de Widmer em duas fases: “[...] um período suíço, correspondendo aos anos de formação musical e primeiras composições (de 1927 a 1955), e um período brasileiro, correspondendo à maturidade composicional e maior número de obras compostas (de 1956 a 1989)" (WINTER, 2005, p. 136, nota 1).

Ernest Widmer se casou com a cantora brasileira Sonja Born. Após férias no Brasil, em 1956, foi convidado por Hans-Joachim Koellreutter (1915-2005) - reconhecido compositor, ensaísta, educador alemão naturalizado brasileiro e criador do movimento Música Viva - para participar dos Seminários Livres de Música da Universidade Federal da Bahia. Desde então, estabeleceu-se em Salvador, onde passou grande parte de sua vida profissional. Como compositor, produziu mais de 170 obras entre óperas, balés, oratórios, música para orquestra, concertos, música para peças teatrais, trilhas para filmes e outros gêneros.

Atuante da vanguarda musical brasileira da segunda metade do século XX, em 1966, criou o Grupo de Compositores da Bahia, fundamentado na ideia de liberdade de criação, como ele mesmo declarou: "Para encontrar nossa identidade, precisamos nos livrar de preconceitos, preceitos, correntes, correias e escolas" (ERNST [...], [s.d.b]). Sua obra traz diversidade estética, com traços da música tradicional nordestina - pela qual se interessou especialmente -, da vanguarda europeia e estadunidense, da música afro-baiana e do folclore de diversos países (WINTER, 2005, p. 121-122).

\footnotetext{
10 "At the age of fourteen I realised that I belonged to music" (WIDMER).
} 


\section{Ludus Brasiliensis}

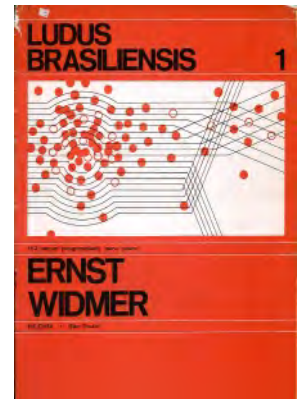

Ludus Brasiliensis - 5 cadernos de peças progressivas para piano solo foi publicado em 1966. Nas primeiras páginas de cada caderno, Widmer (1966, p. 3) afirma que os cinco livros pretendem contribuir para uma iniciação ao piano, com os objetivos de:

- abrir caminhos para a compreensão da música moderna;

- despertar o espírito criador do estudante através de improvisações;

- cuidar da independência das mãos através de cânones de melodias conhecidas;

- fornecer material para a leitura à primeira vista;

- facilitar o estudo dos ornamentos e de polirritmos;

- apresentar músicas com três e mais pautas para acostumar o estudante a ler partituras e tocar em conjunto.

Os livros têm progressão de dificuldades técnicas e musicais, e os cadernos devem ser estudados peça a peça, sequencialmente. As peças de leitura e improvisação, assim como as de gênero - dança, scherzo, noturno, entre outras -, são numeradas com algarismos romanos iniciando no livro 1, seguindo a sequência pelos seguintes, terminando no livro 5.

O padrão de indicações de cada peça lembra aquelas do Mikrokosmos, de Béla Bartók, a saber: um pequeno pentagrama indica a extensão das notas da mão direita e da mão esquerda, o andamento é indicado pela figura que representa a pulsação com o número metronômico em cima da pauta, e os segundos aparecem no final de cada peça, à esquerda.

Algumas características do método revelam os princípios pedagógico-musicais de Ernest Widmer:

- o uso das claves de sol e de fá já na primeira peça no livro 1;

- a grande maioria das peças são modais, com poucas peças tonais;

- o uso de teclas pretas logo na segunda peça do livro 1;

- a indicação de batimentos na madeira do piano em várias músicas;

- o uso dos pedais no primeiro livro; 
- desde o livro 1, movimento paralelo com as duas mãos, melodia distribuída entre as duas mãos, melodia e acompanhamento, mãos alternadas e condução polifônica entre as duas mãos;

- ao lado dos tradicionais compassos binários, ternários e quaternários, o uso de compassos diversos, como de 5, 1, 3+2 e 7 .

A estrutura dos livros é semelhante e constitui-se de:

- 13 peças para leitura à primeira vista, distribuídas pelos cinco livros. O autor recomenda a leitura na presença do professor e propõe algumas etapas a serem seguidas: observar a peça antes de tocar e identificar problemas de dedilhado, ritmo e outros aspectos; ler as frases sempre adiante; tocar devagar etc.

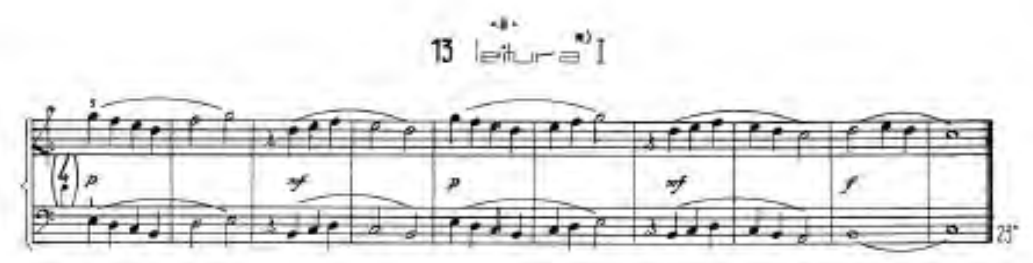

- Peças para "improvisação dirigida". Na introdução de cada livro, o autor orienta o aluno e o professor. Aos alunos, recomenda, por exemplo: "verifique os elementos exigidos e prepare-se em conformidade com isto; toque, improvisando espontaneamente, sem premeditação; caso não consiga improvisar na primeira tentativa, não desanime, experimente mais tarde novamente" (WIDMER, 1966, p. 3). Em relação ao professor, uma das recomendações revela sua preocupação em acolher a produção do aluno, orientando que "não corrija a escolha de notas, acordes ou ritmos do estudante (mesmo tratando-se de acordes 'absurdos', por exemplo)" (WIDMER, 1966, p. 3).
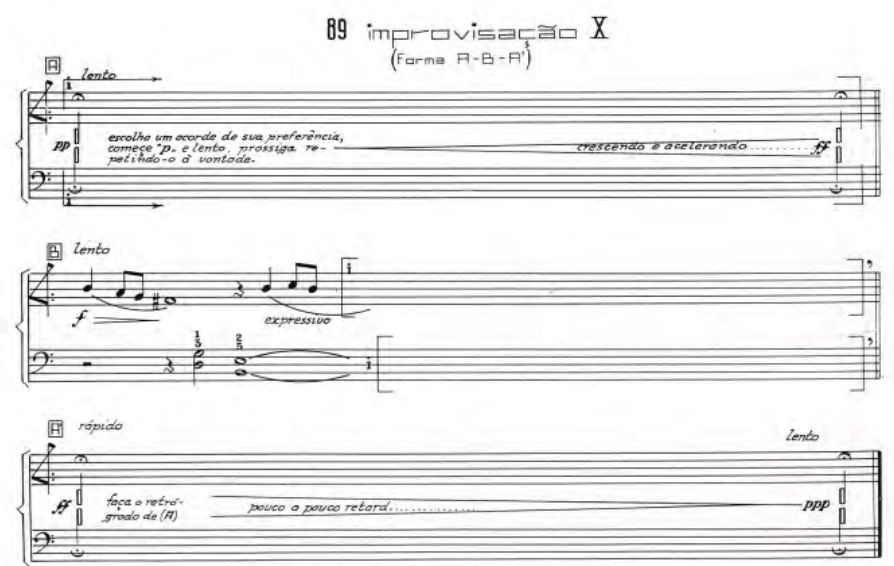
- Canções tradicionais brasileiras e de outros países e composições do autor. Com exceção do livro 5, que tem apenas uma canção, e do livro 3, que não tem nenhuma, cada livros apresenta de 9 a 13 canções. Algumas são enumeradas, como as canções suíças (I a IV), e estão em mais de um livro.

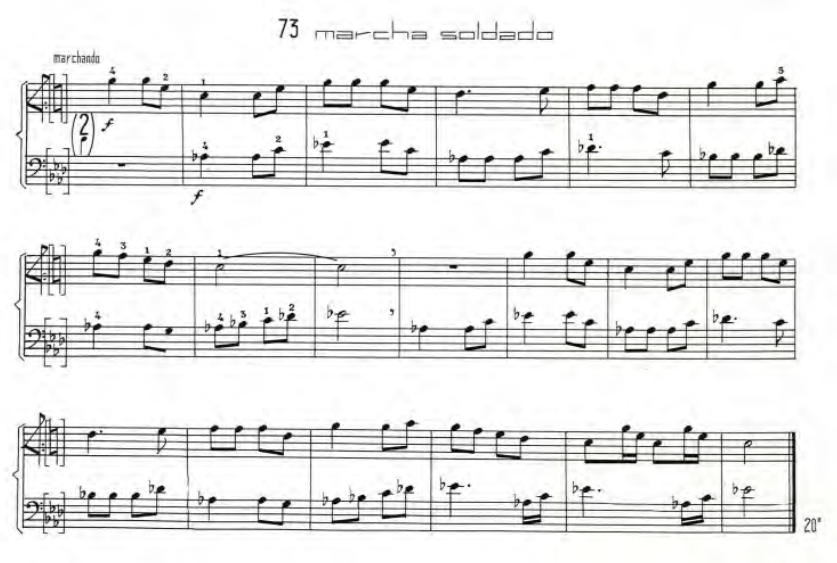

RB 0122

- Peças de outros gêneros como scherzo, rondó, cânone, variações, noturno e gigue. Algumas têm numeração e estão distribuídas entre os livros; por exemplo: scherzo (I, II e III), noturno (I e II), dança (I e II). Há outras que não constituem gêneros, como contraponto (I e II) e mão única (I, II e III).

- Peças com dificuldade técnico-musical específica. No livro 3, há 10 peças polirrítmicas e 7 peças com ornamentos.

- Peças para tocar em conjunto. Há peças com 3 pautas e a 4 mãos. O autor indica que o objetivo dessas peças é "acostumar o estudante a ler partituras e tocar em conjunto" (WIDMER, 1966, p.3).

Após a análise dos cinco livros de Ernest Widmer, é notável a importância que o autor deu ao espaço da criação e à familiarização com a linguagem da música contemporânea. Diante disso, surge uma pergunta que, para ser respondida, exigiria uma pesquisa mais aprofundada que não é foco dessa dissertação: por que um método brasileiro inovador e de boa qualidade é tão pouco conhecido e adotado pelos professores de piano? 


\section{Játékok - György Kurtág}

Verbete biográfico: György Kurtág é compositor, pianista e professor de piano. Nasceu em 1926, na cidade de Lugoj, na Romênia, e, hoje, aos 87 anos, continua em atividade. Com sua esposa, a também pianista Marta Kurtág, tem realizado concertos e gravado excertos dos 8 volumes do Játékok (GOUVEIA, 2010, p. 14). Já recebeu vários prêmios por suas composições.

O pianista e professor Horácio Gouveia aponta a história pessoal de Kurtág em relação ao piano como disparadora de sua "empreitada pedagógica e composicional". Kurtág iniciou seus estudos pianísticos aos cinco anos e desistiu aos sete pois "era muito chato ter de pensar nos dedilhados, nos ritmos e permanecer sempre no mesmo registro do instrumento" 11 (KURTÁG apud ALBÈRA et al., $1995^{12}$ apud GOUVEIA, 2010, p. 15). A ludicidade presente no Játékok foi uma busca do próprio compositor, ainda segundo Gouveia:

Talvez essa seja a "viagem autobiográfica ou biográfica de cada um de nós" a que ele se refere ${ }^{13}$ : a peregrinação ao lado infantil que se perdeu e que ao longo de toda nossa vida devemos tentar recuperar. Aliás, no comovente texto em homenagem ao amigo falecido Ligeti, Kurtág cita que observar as criações das fantasias de Lukas, filho de seu amigo, gerou uma série de ideias que empregou nos Jogos. Talvez influenciado por seu pai György, que quando criança escrevera sobre um mundo imaginário (que chamou de Kylwryia) - desenhando seus mapas e descrevendo seu idioma, gramáticas etc. -, o menino Lukas Ligeti também produziu a "enciclopédia de seu planeta inventado, com exemplos de sua história científica, literatura, artes e música". ${ }^{14}$ Os exemplos musicais dessa enciclopédia, afirma Kurtág, foram um dos pontos de partida para seus Jogos (GOUVEIA, 2010, p. 17).

Kurtág se graduou na Academia Liszt, em Budapeste, onde, mais tarde, lecionou piano e música de câmara, de 1967 a 1993. Os húngaros Béla Bartók e Kodály foram suas primeiras influências, embora mais tarde tenha sido reconhecido como herdeiro do expressionismo de Webern, por empregar em suas composições uma técnica serial e ter preferência por miniaturas (CUMMINGS, 1995, p. 349).

\footnotetext{
11 “[...] parce que c'était três ennuyeux de devoir penser aux doigtés, aux rythmes et de resteur toujours dans le même registre" (KURTÁG apud ALBÈRA et al., 1995).

12 ALBÈRA, Philippe et al. György Kurtág: entretiens, textes, écrits sur son oeuvre. Genève: Éditions Contrechamps, 1995, p. 22.

${ }^{13}$ KURTÁG apud ALBÈRA, Philippe et al. Op. cit., p. 21: “[...] voyage autobiographique ou le voyage biographique de chacun de nous" [nota do original].

14 KURTÁG apud VARGA, Bálint András (ed.). Gyorgy Kurtág: Three interviews and Ligeti homeages. Rochester: University of Rochester Press, 2009, p. 91: “[...] his son Lukas spent years writing encyclopedia of his invented planet, with examples of scientific history, literature, fine arts and music" [nota do original].
} 
Em 1957 e 1958, época de grande repressão do regime comunista húngaro, que proibira composições de Schoenberg, Stravinsky e mesmo algumas de Bartók, morou em Paris, onde estudou com Olivier Messiaen, Darius Milhaud e Max Deutsch. Mesmo curta, sua estadia na cidade francesa foi determinante para sua vida pessoal e profissional como compositor. Durante esse tempo, tratou-se com a terapeuta húngara Marianne Stein para tentar curar uma séria depressão que, em suas próprias palavras, foi um "desmoronamento de todo um mundo. Não apenas do mundo exterior, mas também do meu universo interior" (KURTÁG apud GOUVEIA, 2010, p. 18). Ainda em Paris, compôs seu quarteto de cordas, que, dedicado a Marianne Stein e denominado de Opus 1, marcou uma nova fase de sua vida.

Outra importante influência sobre sua carreira composicional foi seu contato com a música eletrônica alemã do Estúdio WDR, em Colônia.

Em Budapeste, dentre diversas atividades como compositor e pianista, Kurtág começou a escrever Játékok, publicando os primeiros volumes em 1979. Segundo Gouveia (2010, p. 14), o pianista francês Claude Helffer considera a composição uma importante referência entre as obras pianísticas do século XX.

\section{Játékok}

Játékok é uma coleção de 8 livros para piano, pouco conhecida no Brasil. Sua abordagem é bastante diferenciada, apresentando peças que vão desde um nível elementar até um muito avançado em termos de interpretação pianística.
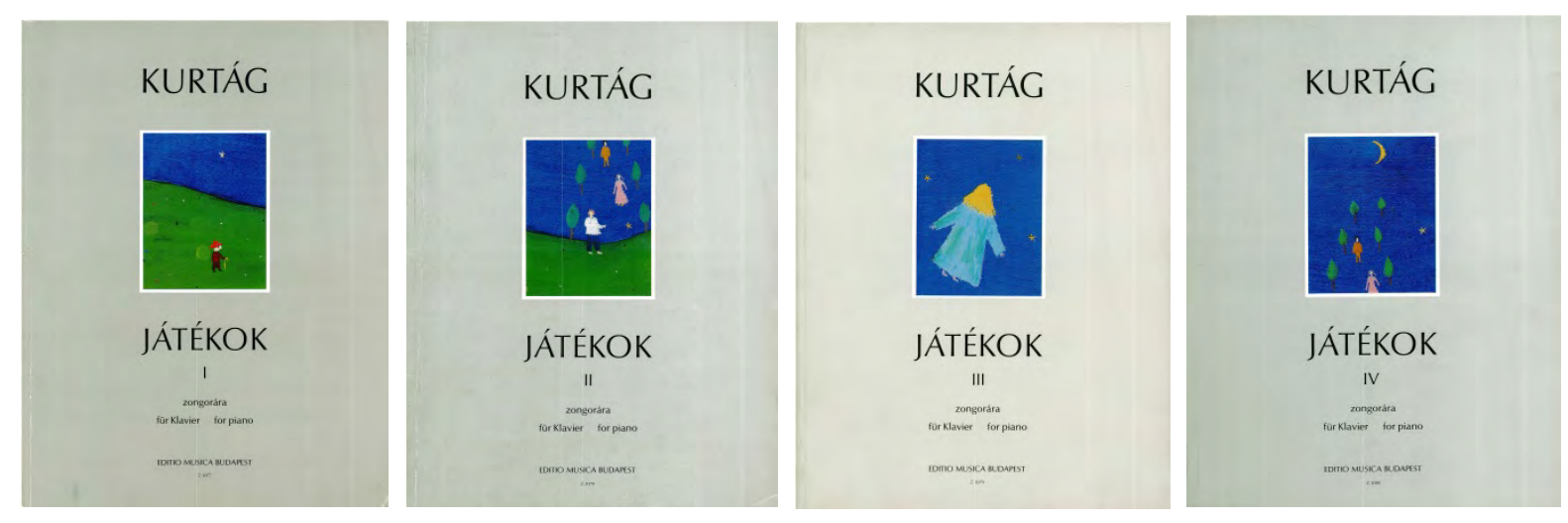
As crianças são o ponto de partida da coleção e "a questão fundamental da obra não é 'ensinar piano', mas desenvolver ludicamente as possibilidades criativas do intérprete" (GOUVEIA, 2010, p. 17). Nas palavras do próprio compositor:

\begin{abstract}
A ideia para a composição de jogos foi proporcionada pela criança que brinca esquecida de si mesma. A criança, para qual o instrumento ainda é um brinquedo. Ela o experimenta de todas as formas, o acaricia, por vezes o maltrata. A criança parece sobrepor sons desconexos e, quando isto parece haver despertado seu instinto musical, ela se volta conscientemente para experimentações, pesquisando e repetindo certas harmonias criadas por acaso. Dessa maneira, esta série não representa, de forma alguma, uma escola de piano, nem uma coletânea desarticulada de peças. Ela é uma possibilidade para a experimentação e não um método para piano (KURTÁG, 1979, prefácio apud GOUVEIA, 2010, p. 79).
\end{abstract}

Nesse mesmo prefácio, Kurtág expõe os princípios norteadores de toda a série ("O piano como brinquedo", "A alegria do movimento" e a "Possibilidade de experimentar"), reveladores de seu diferencial: essa concepção, em que experimentação, ludicidade, relação corporal com o fazer musical e aproximação da música contemporânea compõem a fundamentação dos livros.

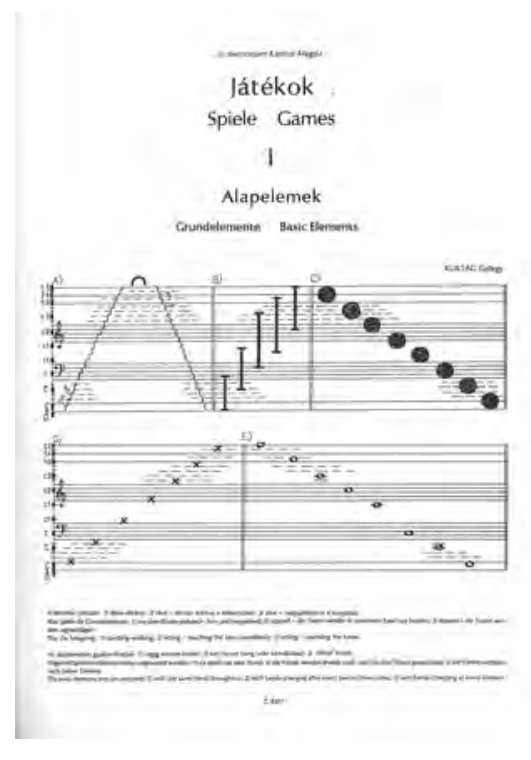

O próprio nome, que significa "jogos" em húngaro, apresenta o piano como um brinquedo com inúmeras possibilidades de experimentação, demonstrando uma proposta bem próxima do pensamento pedagógico-musical contemporâneo, em que a construção do conhecimento pelo próprio aluno e a experimentação sonora são estimuladas, e o espaço da criação, garantido. A pianista e pesquisadora Helena Cabezas declara que com o Játékok as crianças percebem e interiorizam os fenômenos musicais de forma bastante natural, passando 
pelas dimensões sensorial e afetiva, sendo essa conexão entre aprendizagem e ludicidade o que "rompe com o sistema de ensino tradicional que parte da leitura da partitura e da técnica digital como únicos desencadeantes do universo pianístico e musical" (CABEZAS, 2012, p. 2). A mesma pianista aprofunda as possibilidades de exploração propostas no Játékok:

As peças do Játékok são projetadas com o intuito de ser a base para uma experimentação em diversas vertentes: a exploração gestual do corpo, a exploração topográfica do teclado, a exploração musical de sonoridades distintas (clusters, glissandos...) e a exploração de novas formas de notação musical são alguns dos exemplos. Esta diversidade de "possibilidades de experimentação" deriva principalmente da notação não determinada criada por Kurtág especificamente para o Játékok. Justamente essa indeterminação oferece ao aluno a oportunidade de "completar" a peça, isto é, de determinar ele mesmo alturas e durações de notas e pausas. Portanto, os parâmetros não detalhados conformam um estímulo para a cocriação junto com o aluno, ou seja, um impulso para sua criatividade musical (CABEZAS, 2012, p. 5).

É importante ressaltar alguns dos conteúdos musicais e técnicos que apontam essa concepção diferenciada das peças de Kurtág: linguagem pianística contemporânea; notação musical não tradicional; imprecisão métrica, valorização do gesto como movimento produtor expressivo de sonoridades; material musical reduzido com potencialidade expressiva; uso de registros sonoros mais do que contornos melódicos; exploração de timbres diversos, assim como aumento da gama de intensidade e de articulações, entre outros. Cabezas ([s.d.], p. 6) cita ainda o caráter performático, presente em "algumas peças que propõem exercícios de encenação", procurando "capturar a expressividade da própria teatralização de determinados estados anímicos ou ações [...] para depois conferi-los na execução musical”.
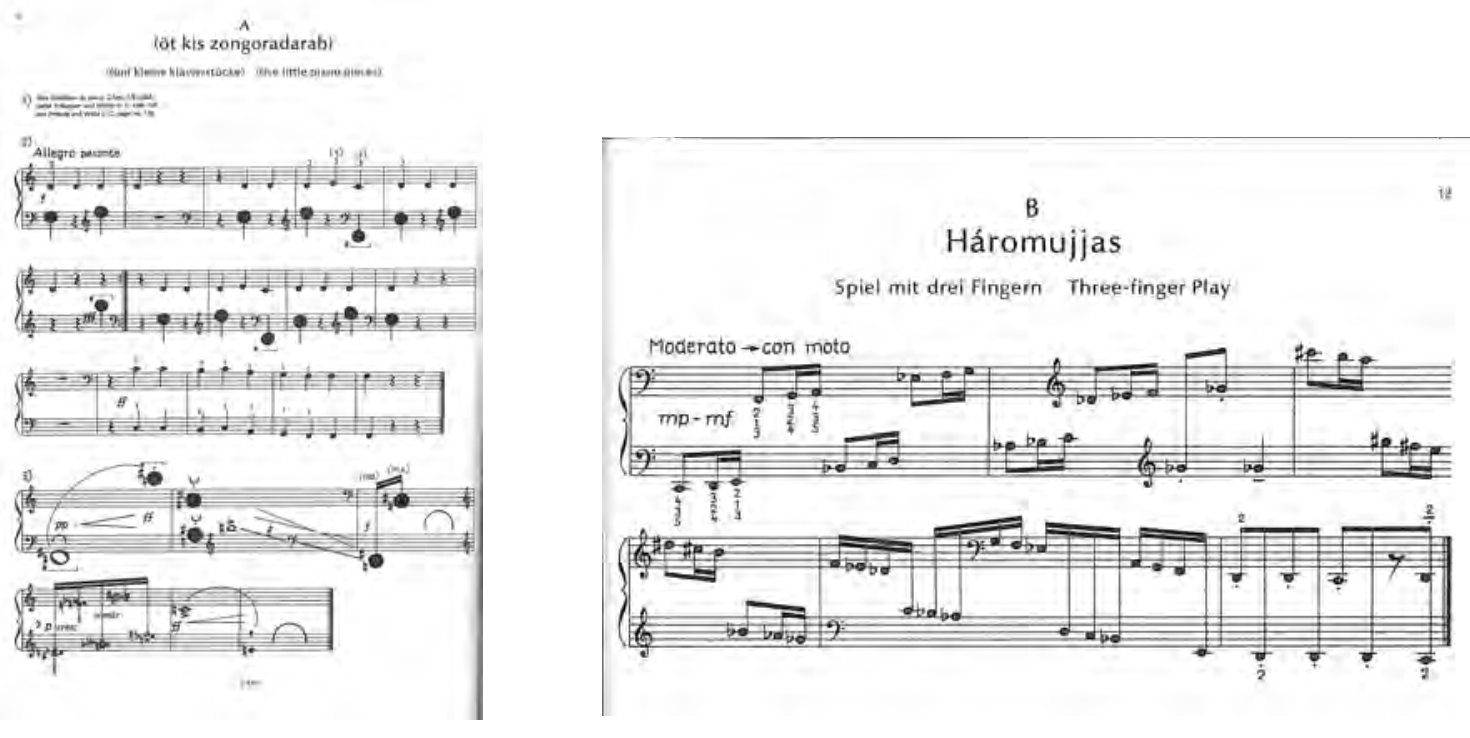
É conclusivo que Játékok pode enriquecer muito o processo criativo de ensino e aprendizagem de piano, objetivo da reflexão dessa pesquisa, além de estimular a aproximação do aluno iniciante com a música do século XX. Creio estar validada a colocação de Cabezas (2012, p. 7) de que a reunião de importantes aspectos como "a ludicidade, o corpo e a criatividade, num profuso e rico material pedagógico para piano, coloca-o num diferenciado território da educação pianístico-musical atual”.

\section{Método para piano - Violeta Hemsy de Gainza}

Verbete biográfico: Violeta Hemsy de Gainza é pianista, autora de mais de quarenta títulos e uma das principais referências em educação musical na América Latina e na Península Ibérica. Em 1995, fundou o Foro Latinoamericano de Educación Musical (FLADEM), do qual foi presidente até 2005.

Foi professora titular de Didática Musical e Técnicas de Improvisação na Universidad de La Plata, e lecionou nos conservatórios Nacional Carlos López Buchardo e Municipal Manuel de Falla, ambos em Buenos Aires. Dirige, com Susana Kesselman, a coleção Corpo, Arte e Saúde do Grupo Editorial Lumen, sediado em Buenos Aires (BIOGRAFÍA [...], 2008). Com mais de 80 anos, encontra-se em plena atividade como professora de piano e educadora musical, e ministra workshops, palestras e conferências na Argentina e em diversos países.

Gainza nasceu em Tucumán, na Argentina, em 1930, e, por volta dos treze anos, começou a dar aulas de música para crianças (GAINZA, 2007, p. 117). Concluiu três cursos universitários de diferentes áreas: Música e Química, na Universidad Nacional de Tucumán, e Psicologia Social, na Primeira Escuela Privada de Psicología Social Enrique Pichon Rivière. Especializou-se em pedagogia musical na Teachers College Columbia University, nos Estados Unidos (BIOGRAFÍA [...], 2008). Ao se descrever como uma jovem tímida, com dificuldades de comunicação e expressão, afirma que foi superando as limitações e aprendendo a se expressar por meio do ensino e com as próprias crianças (GAINZA, 2007, p. 117). Seu marido Enrique Gainza influenciou muito sua ideia de responsabilidade social, e seus sobrinhos, também seus alunos, foram o estímulo inicial para sua conscientização da importância da criação no ensino musical. 
Com profundo conhecimento das pedagogias musicais ocidentais desenvolvidas ao longo do século XX e uma reflexão profunda sobre sua prática como educadora, Gainza atua no cenário da educação musical de forma intensa, publicando muitos artigos e participando de congressos e seminários como palestrante e conferencista.

O corpo de suas ideias é bastante amplo, mas alguns conceitos fundamentais de seu pensamento pedagógico-musical têm especial interesse para essa pesquisa: o modelo artístico de educação musical, a prática reflexiva e a pedagogia aberta. O desenvolvimento da criatividade pela participação ativa do aluno é a ênfase do modelo artístico de educação musical, sendo a improvisação o principal recurso pedagógico. A prática reflexiva consiste em '[...] 'fazer' de maneira consciente. O que se procura integrar na nova práxis é recuperar os distintos tipos de consciência de que falava Edgar Willems. A nova práxis integra todos os aspectos do fazer musical"15 (GAINZA, 2013, p. 212, tradução nossa). Em uma publicação do FLADEM, Alejandro Simonovich, músico e educador musical argentino, apresenta o conceito de pedagogia aberta:

\begin{abstract}
Abertura é não prender-se em modelos, porém sem desprezá-los [...] é aceitar outras formas de organização do ensino. Mas não só no âmbito pedagógico. A abertura real é mental, é a aceitação, a compreensão e a utilização da diversidade estética, filosófica, pedagógica, ideológica e musical. É também boa disposição para lançar-se em experiências e estar atento e aproveitar os emergentes. [...] Por fim, abertura pedagógica é uma posição humanista na educação ${ }^{16}$ (SIMONOVICH, 2009, p. 19, tradução nossa).
\end{abstract}

Violeta de Gainza não criou um método para o ensino de música, mas sempre acompanhou novas tendências, advogando por uma educação musical criativa e reflexiva, que busque a identidade cultural e musical dos países latino-americanos. Publicou vários livros voltados ao ensino de piano, entre eles os três volumes de Método para piano, dos quais descrevo o primeiro.

\footnotetext{
15 “'[...] 'hacer' de una manera conciente. Lo que se procura integrar en la nueva praxis es recuperar los distintos tipos de conciencia de los que hablaba Edgar Willems. La nueva praxis integra todos los aspectos del hacer musical" (GAINZA, 2013, p. 212).

16 “Apertura es no atarse a modelos, pero sin desdeñar modelos [...] es aceptar otros modos de organizar la enseñanza. Pero no sólo no pedagógico. La real apertura es mental, es la aceptación, comprensión y aprovechamiento de la diversidad estética, filosófica, pedagógica, ideológica y musical. Es también buena predisposición, tomar y utilizar experiencias y atender a los emergentes. [...] En definitiva, apertura pedagógica es una posición humanista en educación" (SIMONOVICH, 2009, p.19).
} 


\section{Método para piano}

Método para piano foi publicado em Buenos Aires pela editora Barry. É composto de três volumes, sendo que os dois primeiros têm um livro complementar.

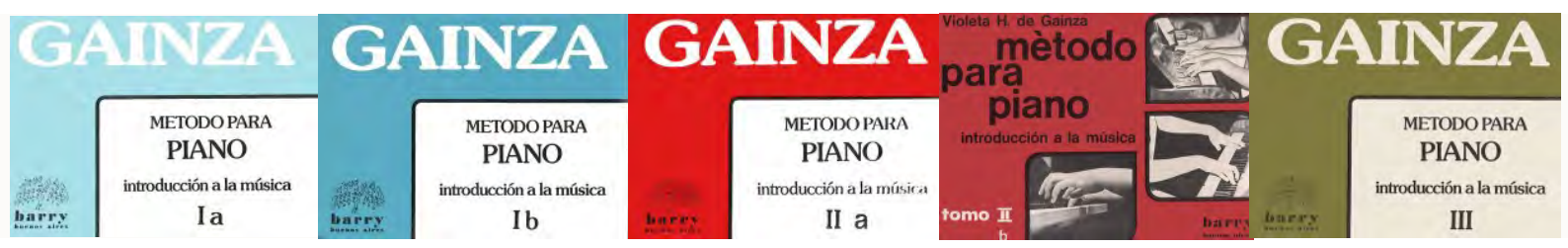

No prefácio do livro I, Gainza ([s.d.], p. III) diz que o método é resultado de sua prática como professora de piano para crianças a partir dos 7 anos e como formadora de professores de piano por mais de vinte anos, e apresenta sua forma de trabalho:

Fazer música, viver a música, compreendê-la através da prática no teclado [...]. Ensinamos a criança a reconhecer e manipular as estruturas básicas rítmicas, melódicas, harmônicas, formais, estilísticas - da música que escuta mais frequentemente no meio em que vive, estimulando-a, ao mesmo tempo, desde o começo, a explorar o teclado e descobrir por si mesmo novos ordenamentos e estruturas ${ }^{17}$ (GAINZA, [s.d], p. III, tradução nossa).

A autora enfatiza a importância de se considerar o que é sonoramente familiar à criança para, a partir disso, introduzi-la às obras que compõem o repertório tradicional de piano. Assim, há no repertório composições dos alunos, da própria Gainza e de outros educadores musicais, melodias tradicionais argentinas e de países como França, Turquia, Finlândia, Inglaterra, Alemanha e Espanha, e outras de compositores como Schubert, Hiller, Turk, Mozart, Orff, Bártok e Kabalevsky.

A escrita tradicional é apresentada desde o início, e só a primeira peça do livro é escrita com gráfico no perfil melódico, com indicação dos números dos dedos. As propostas musicais do método estão no âmbito da tonalidade e se iniciam com o pentacórdio, enfatizando os diversos elementos estruturais da linguagem tonal. A transposição guiada pela

\footnotetext{
17 “Hacer música, viver a música, comprenderla a través de la práctica sobre el teclado [...] Enseñamos al niño a reconocer y manejar las estructuras básicas - rítmicas, melódiccas, armónicas, formales, estilísticas - de la música que escucha más frecuentemente en el medio en que vive, estimulándole al mismo tiempo, desde el comienzo, a explorar el teclado y descubrir por sí mismo nuevos ordenamientos y estructuras” (GAINZA, [s.d], p. III).
} 
audição é estimulada desde o princípio. Os conceitos teóricos são apresentados a partir de cada peça, que, segundo Gainza ([s.d], p. V, tradução nossa), “[...] constitui-se uma unidade significativa na qual se encontram naturalmente fundidos os distintos aspectos da música (ritmo, melodia, harmonia, forma) e da execução instrumental". ${ }^{18}$

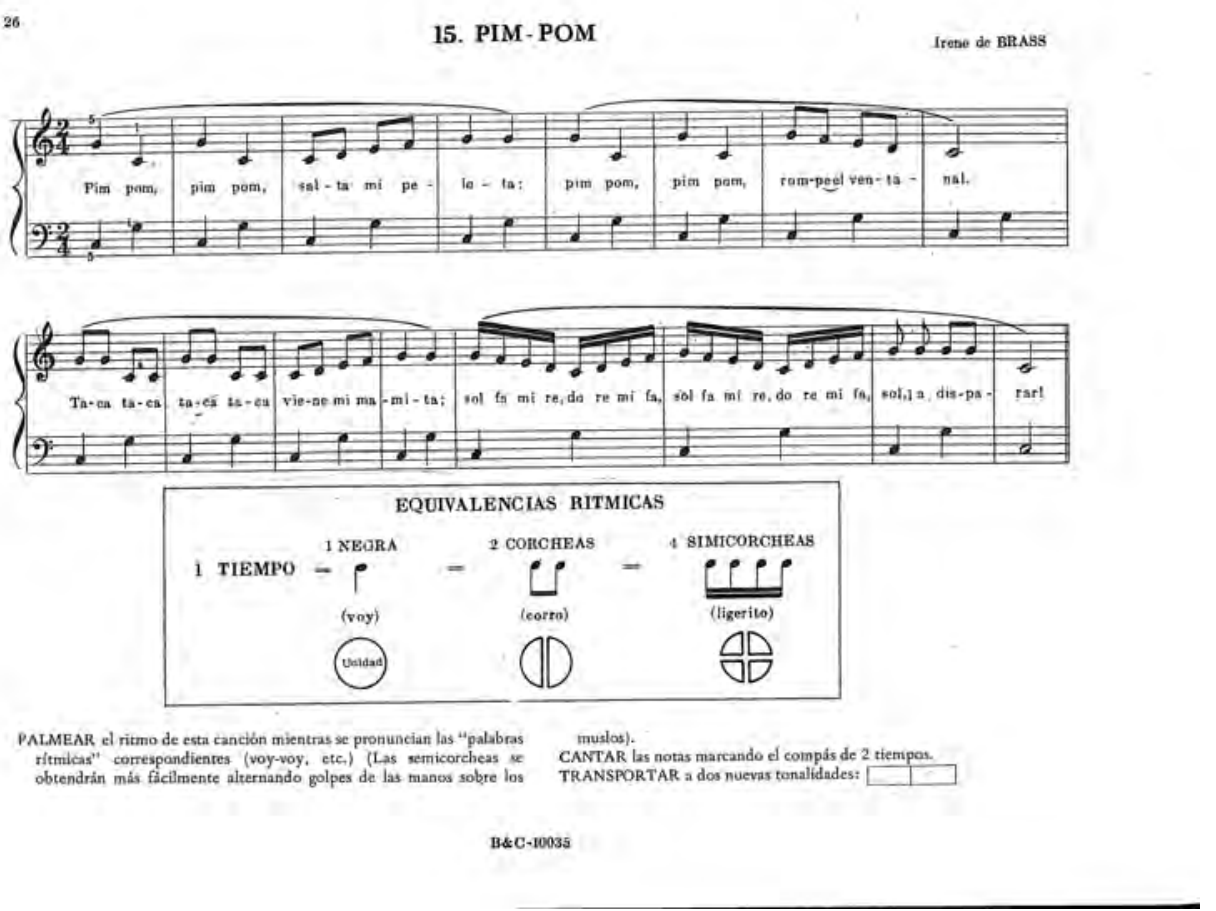

No Guia Didático apresentado nas primeiras páginas do livro, Gainza sugere formas de trabalhar cada peça a partir da partitura, observando título, autor, aspecto melódico, aspecto rítmico, aspecto harmônico, aspecto formal, fórmulas de acompanhamento (conteúdos apresentados em quadros na mesma página), dedilhado, signos e indicações escritas. Há ainda atividades complementares de transposição de tonalidade, leitura e escrita musical, ditados musicais, improvisação etc.

\footnotetext{
18 "Cada trozo o canción constituye una unidad significativa en la que se encuentran naturalmente fundidos los distintos aspectos de la música (ritmo, melodía, armonía, forma) y de la ejecución instrumental" (GAINZA, s/d, p. V).
} 
ACORDES INCOMPLETOS

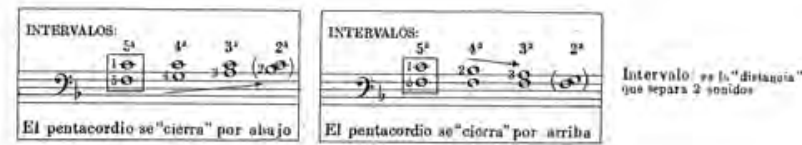

32. MELODIA

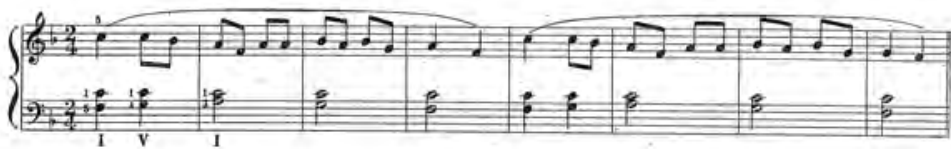

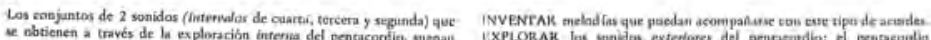

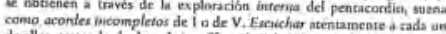

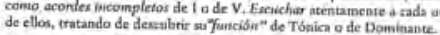

A autora afirma que a criação surgirá naturalmente se o trabalho com as estruturas musicais e instrumentais for claro e sistemático. "Cada novo tema apresentado ao aluno pode converter-se automaticamente em tema de improvisação ou exploração pessoal, atividade capaz de conduzir à criação de uma breve composição musical" ${ }^{19}$ (GAINZA, [s.d.], p. VII, tradução nossa). Algumas atividades complementares estimulam a criação, por exemplo: inventar uma melodia em determinada tonalidade, criar um acompanhamento, mudar o ritmo, inventar uma melodia para determinados acordes, completar acordes ou frases.

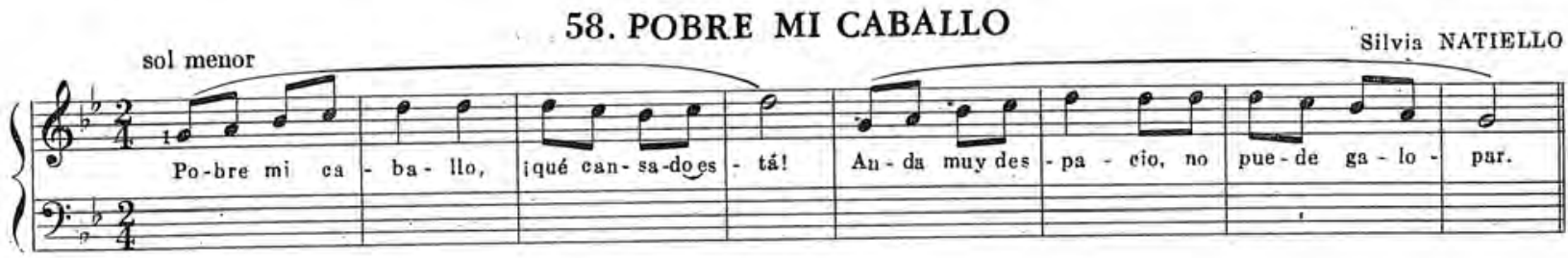

INVENTAR y excribir acompaumiencus adecuades para estas melodias. IMPR()VISAR en las romalidades de sol menor y domener.

BEC- 10035

19 "Cada nuevo tema presentado al alumno puede convertirseautomáticamente en un tema de improvisación o exploración personal, actividad capaz de conducir a la creación de una breve composición musical" (GAINZA, s/d, p. VII). 
Em Método para piano, Gainza revela a importância da prática reflexiva em sua concepção do ensino de piano. Desde a introdução, Gainza explicita a prioridade de um processo consciente por parte do aluno, que deve se apropriar da peça mecânica, musical, expressiva e intelectualmente. O método se desenvolve dentro do âmbito da tonalidade e da escrita tradicional, mas a criação é tão valorizada quanto a leitura, a assimilação de conceitos teóricos, a progressão técnica etc. Dentre as diversas peças, há melodias compostas pelos próprios alunos, o que reforça a importância da criação para a autora.

\section{Sons da infância - Marisa Fonterrada e Maria Lúcia Pascoal}

Verbete biográfico: Marisa Trench de Oliveira Fonterrada é educadora musical e autora de diversos artigos e livros. Considerada referência na educação musical brasileira, é professora livre-docente em Técnicas de Musicalização e professora titular e coordenadora do Grupo de Estudo e Pesquisa em Educação Musical, ambos do Instituto de Artes da Universidade Estadual de São Paulo (IA-UNESP), do qual foi diretora.

De 1967 a 1977, trabalhou com Schnorrenberg nos Cursos Internacionais de Férias de Curitiba. Foi diretora da Escola Municipal de Música e, com a professora Maria Elisa Bologna, criou a Escola Municipal de Iniciação Artística (EMIA). Foi responsável pela instalação e coordenação da ETEC de Artes do Centro de Educação Tecnológica Paula Souza, da Secretaria de Estado do Desenvolvimento de São Paulo, no período de 2008 e 2009. Fonterrada é membro fundador de The World Forum for Acoustic Ecology e do Fórum Latino-Americano de Educação Musical (FLADEM).

Fonterrada nasceu em Botucatu, no estado de São Paulo, e começou a estudar piano com a professora Maria Aparecida Eichenberg. Mudou-se para Piracicaba, continuou seus estudos de música e foi aluna fundadora da Escola de Música de Piracicaba, àquela época sucursal dos Seminários de Música Pró-Arte, de São Paulo, onde teve oportunidade de estudar com músicos renomados como Hans-Joachim Koellreutter, Damiano Cozzella, Isaac Karabitschevski, Ernst Mahle e Maria Dirce Camargo. Em São Paulo, fez o Curso de Formação de Professores de Música como bolsista da Secretaria de Estado da Cultura de São 
Paulo, e teve como professores Roberto Schnorrenberg, Osvaldo Lacerda, Cyro Brisolla, Damiano Cozzella e Diogo Pacheco (informação pessoal). ${ }^{20}$

Em 1977, graduou-se bacharel em Música pela Universidade São Judas Tadeu. Recebeu os títulos de mestre em Psicologia da Educação, em 1991, e doutora em Antropologia, em 1996, ambos pela Pontifícia Universidade Católica de São Paulo (PUC-SP). Em 2001, obteve a livre-docência no Instituto de Artes da Universidade Estadual de São Paulo (IA-UNESP) (FONTERRADA, 2014b).

Na década de 1980, Fonterrada viajou ao Canadá para estudar o trabalho de Murray Schafer, que:

[...] mudou muito a minha maneira de trabalhar, porque [...] embora seja um músico contemporâneo e trabalhe com todas as técnicas de música contemporânea, Murray Schafer tem um lado a mais, que é a posição de educador. Tem um outro lado ainda que é compreender a música como uma faceta do desenvolvimento humano (FONTERRADA, 2014a).

Responsável pela tradução dos livros de Schafer para o português e por introduzi-lo na educação musical brasileira, entre 1990 e 2011, trouxe diversas vezes o compositor para o Brasil para ministrar workshops e conferências. Atualmente, Marisa Fonterrada reside em Carapicuíba (SP) e atua ativamente nas áreas de educação musical, música, canto coral, ecologia acústica e na área de artes no ensino fundamental, médio e superior (FONTERRADA, 2014b). Ainda no final da década de 1970, escreveu com Maria Lúcia Pascoal Sons da infância, um método para piano analisado nesta pesquisa.

Verbete biográfico: Maria Lúcia Senna Machado Pascoal é pianista, pesquisadora e professora de Teoria e Análise Musical, e recebeu diversos prêmios por sua atividade e vasta produção acadêmica.

Pascoal participou do grupo que fundou o Departamento de Música do Instituto de Artes da Universidade Estadual de Campinas (UNICAMP), do qual foi chefe e diretora, durante a década de 1990. Entre as décadas de 1990 e 2000, fez parte da Comissão de Especialistas de Ensino do Ministério da Educação e da CAPES. Atualmente, é aposentada pela UNICAMP, onde foi professora e pesquisadora desde 1981 e ainda participa de projetos

20 FONTERRADA, M. T. O. Informações biográficas e Sons da Infância. Mensagem recebida por beremusica@gmail.com em 3 fev. 2014. 
técnico-científicos e na área de ensino, ministrando disciplinas na pós-graduação como professora voluntária (PASCOAL, 2014).

Maria Lúcia Pascoal nasceu em São Paulo e começou a estudar piano com Dinorá de Carvalho. Realizou concertos, recitais e completou os estudos no Curso Superior de Piano na Faculdade Paulista de Arte, na classe de Nair Medeiros, onde graduou-se em Piano, em 1958. Na década de 1960, foi aprovada para o Curso de Formação de Professores de Música, da Secretaria de Estado da Cultura de São Paulo, e foi aluna de importantes nomes do cenário musical da época como Cyro Brisolla, Damiano Cozzella, Diogo Pacheco, Osvaldo Lacerda e Roberto Schnorrenberg.

De 1966 a 1974, participou de várias atividades nos Festivais Internacionais de Música em Curitiba (PR), onde começou a trabalhar com teoria, análise musical e música do século XX. Em 1972, cursou Educação Musical Willems, em São Paulo. Em 1974, com bolsa do Governo Alemão para Estudantes Estrangeiros (DAAD), especializou-se em Neue Musik, no International Music Institute, tendo aulas com compositores importantes da vanguarda do século XX, como Mauricio Kagel, Iánnis Xenákis e Karlheinz Stockhausen. Em 1990, concluiu o doutorado em Música pela Universidade Estadual de Campinas, trabalho que consta no Centre de Documentation Claude Debussy, em Paris (informação pessoal). ${ }^{21}$

Ao lado das diversas atividades acadêmicas, Maria Lúcia Pascoal também foi tecladista da Orquestra Municipal de Campinas e criou o curso de Teoria Musical da Escola Magda Tagliaferro, onde foi professora por dez anos. Segundo a própria biografada, "tem experiência na área de Música com ênfase em Análise Musical, principalmente nos seguintes temas: análise musical, música brasileira, técnicas de composição na música do século XX e música brasileira no século XX” (PASCOAL, 2014).

Além de Sons da Infância, publicou Estrutura tonal: harmonia (livro eletrônico, Cia. Editora Paulista), artigos nas principais revistas brasileiras e nas coletâneas Teoria, Crítica e Música na Atualidade (2012, org. M. Alice Volpe) e Mémoires...Miroirs - Conferências do Simpósio Internacional Jorge Peixinho (Lisboa, 2012, org. Paulo de Assis), e, com Marisa

\footnotetext{
21 PASCOAL, M. L. Informações biográficas e Sons da Infância. Mensagem recebida por
} beremusica@gmail.com em 10 fev. 2014. 
Fonterrada, traduziu $O$ ouvido pensante de Murray Schafer (Ed. Unesp) (informação pessoal). ${ }^{22}$

\section{Sons da infância}

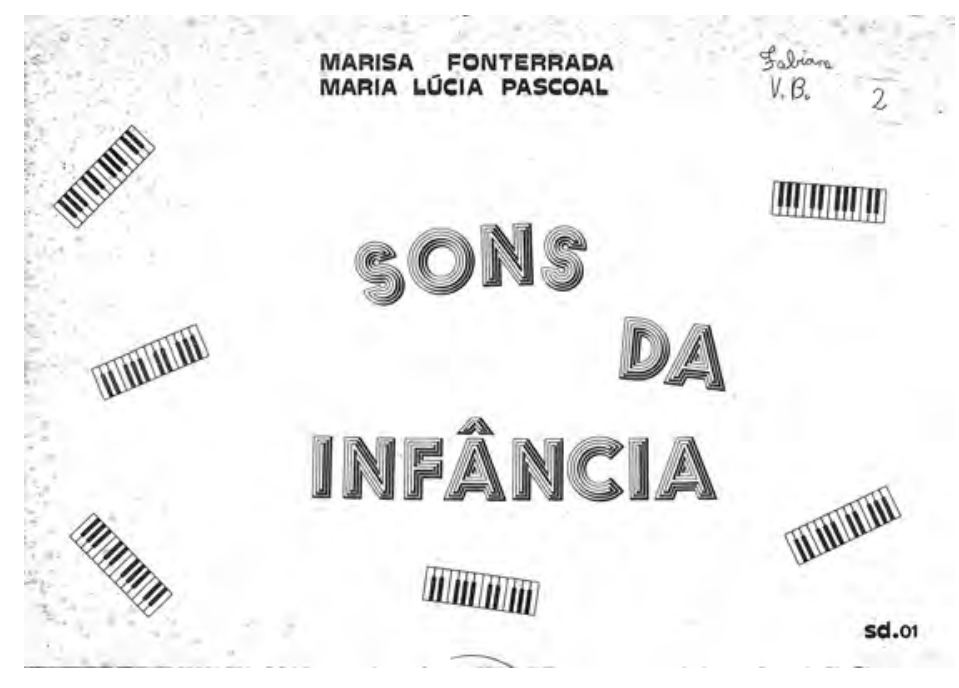

Sons da infância foi publicado em 1979, numa época em que os métodos tradicionais de ensino de piano ainda dominavam a educação musical no Brasil. Desde o começo, as autoras revelam a intenção de trabalhar a música mais amplamente, indo além da técnica, da aquisição de repertório e do aprendizado da escrita tradicional, os três conteúdos centrais no ensino do instrumento na época. Apesar de modesto, há um incentivo à criação, o que demonstra ligação com as tendências da educação musical da década de 1960. Fonterrada e Pascoal (1979, p. 0) fazem algumas recomendações:

1. Cada peça poderá ser estudada:

- cantando;

- cantando e batendo palmas na pulsação e no ritmo;

- tocando a mão direita e batendo a pulsação na esquerda;

- com outras variações.

2. As harmonias das peças para quatro mãos não foram escritas, ficando a critério do professor.

3. Fazer o aluno transpor peças conhecidas para outras tonalidades (treino de ouvido).

4. Incentivar a criatividade do aluno, fazendo-o inventar sobre o que estiver aprendendo.

5. Motivar o aluno para a análise das peças.

22 PASCOAL, M. L. Informações biográficas $e$ Sons da Infância. Mensagem recebida por beremusica@gmail.com em 10 fev. 2014. 
Sons da infância apresenta peças com graduação de dificuldade técnica e de leitura e introduz conceitos musicais ao longo dos exercícios. Logo no início, chama-se a atenção para o entorno sonoro e destaca-se a altura do som, para, em seguida, relacionar esse parâmetro com o piano e propor a criação de uma história em que cada região do teclado é associada a imagens ou personagens.

Depois de desenvolver a percepção da pulsação, as autoras apresentam a escrita tradicional com exercícios na pauta. Desde o começo, utilizam-se as duas claves, de sol e de fá, partindo do dó central - o que também era comum nos métodos de piano norte-americanos introduzidos no Brasil naquela época -, mas não há indicação da fórmula e das barras de compasso, que só são apresentadas na página 31. Para diversificar o trabalho e abordar o teclado todo, há sugestões para se tocar com um dedo, com dedilhados diversos, oitavas acima ou abaixo, com uma mão ou com as duas etc. Além das melodias na pauta, propõem-se exercícios como:

- melodias escritas a partir de movimentos ascendentes e descendentes, com o tempo medido pelas figuras de duração;

- frases rítmicas para serem tocadas na madeira do piano;

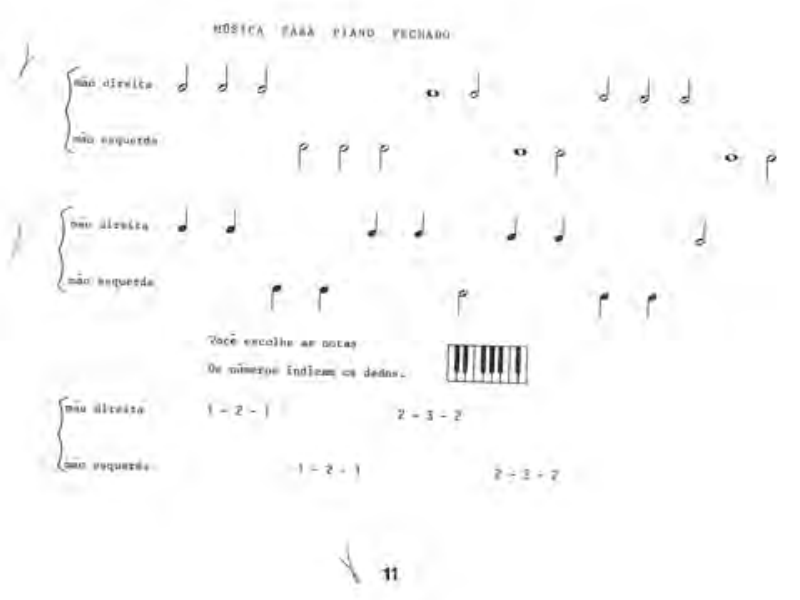

- indicação do dedilhado, porém o aluno é quem escolhe as notas;

- exercícios rítmicos para palmas e pés; 


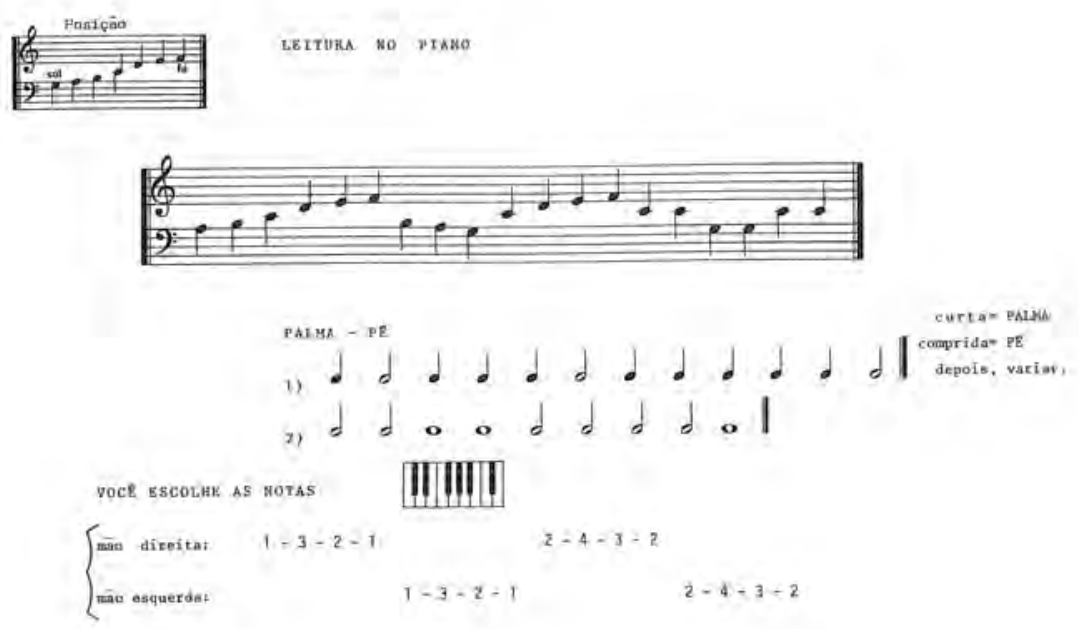

18

- melodias para treinar a leitura.

Os conceitos de sustenido e bemol só aparecem na página 41, antes disso, todas as melodias são tocadas nas teclas brancas, a maioria em Dó Maior e lá menor. Algumas peças estão em outras tonalidades, como Ré Maior, Fá Maior ou mi menor, mas as melodias foram compostas somente com as notas sem alteração. A partir daí, seguem-se melodias que usam só as teclas pretas e outras em modos que fogem dos maiores e menores, aproximando o aluno da sonoridade da produção musical da primeira metade do século XX. Há também propostas de improvisação nas teclas pretas ou em blocos de notas. Nas últimas páginas do livro, há uma pequena peça que faz referência ao compositor húngaro Béla Bartók (18811945) e duas canções tradicionais brasileiras para tocar e cantar.

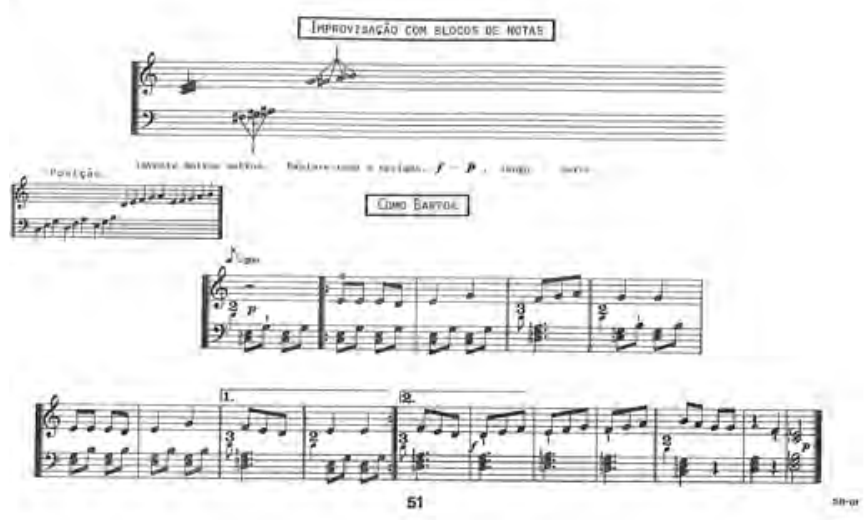


Sons da infância trouxe inovações para o ensino de piano da época, mesmo que pareçam tímidas ao olhar atual. Havia ainda grande preocupação com a escrita tradicional, sem muita aproximação de uma linguagem mais contemporânea. No entanto, o uso de mãos e pés e da madeira do piano, as melodias nas teclas pretas, as improvisações e mesmo a relação que se faz dos parâmetros sonoros com o entorno revelam uma concepção diferenciada do ensino de piano nas décadas de 1970 e 1980 no Brasil, evidenciando uma abordagem mais criativa.

\section{Klavierschule für Anfänger - Harald Bojé}

Verbete biográfico: Harald Bojé foi um pianista alemão, muito conhecido como improvisador e performer de Neue Musik, tocando Electronium $\mathrm{Pi}^{23}$ e sintetizadores, além do piano. Bojé nasceu em 1934, na cidade de Göttingen, e morreu em 1999, em Wuppertal, na Alemanha. Iniciou seus estudos musicais e pianísticos na Academia de Música de Stuttgart e, a partir de 1971, prosseguiu os estudos na Academia de Música de Wuppertal - cidade independente da região da Renânia (Rheinland), na Alemanha - onde, mais tarde, tornou-se professor de piano. Também lecionou no Departamento de Música da Universidade de Colônia, a Hochschule für Musik Köln.

Na década de 1960, envolveu-se com a Neue Musik, interpretando diversas obras de Karlheinz Stockhausen (1928-2007), reconhecido compositor alemão de música de vanguarda do século XX. Bojé se apresentou com o grupo de Stockhauzen, tocando peças importantes como Telemusik, Solo e Kurzwellen usando um Electronium Pi modificado. Grande parte de sua discografia é referente às obras desse compositor.

Na década de 1970, participou de vários concertos, inclusive no Moers Festival de 1978, com o trio formado com Günter Christmann e Detlef Schönberg, reconhecidos músicos de free jazz. Em 1980, fez parte de um grupo de improvisação com os músicos Wolfgang Schmidtke, Martin Zuhr, Matthias Burkert e Gerd Rataj.

\footnotetext{
${ }^{23}$ O Electronium Pi era um teclado eletrônico com controles muito usado por compositores alemães na década de 1950 .
} 
Harald Bojé publicou um livro de piano para iniciantes, Klavierschule für Anfänger, objeto deste estudo, e um para estudantes mais avançados, Klavierliteratur für Fortgeschrittene, em que reuniu obras da música clássica do século XX e do jazz.

\section{Klavierschule für Anfänger}

Klavierschule für Anfänger foi publicado pela Universal Edition, em 1982, em Viena, na Áustria. É um livro de iniciação ao piano, indicado para aulas individuais e em grupo, contendo também algumas peças que podem ser executadas por pequenos conjuntos instrumentais.

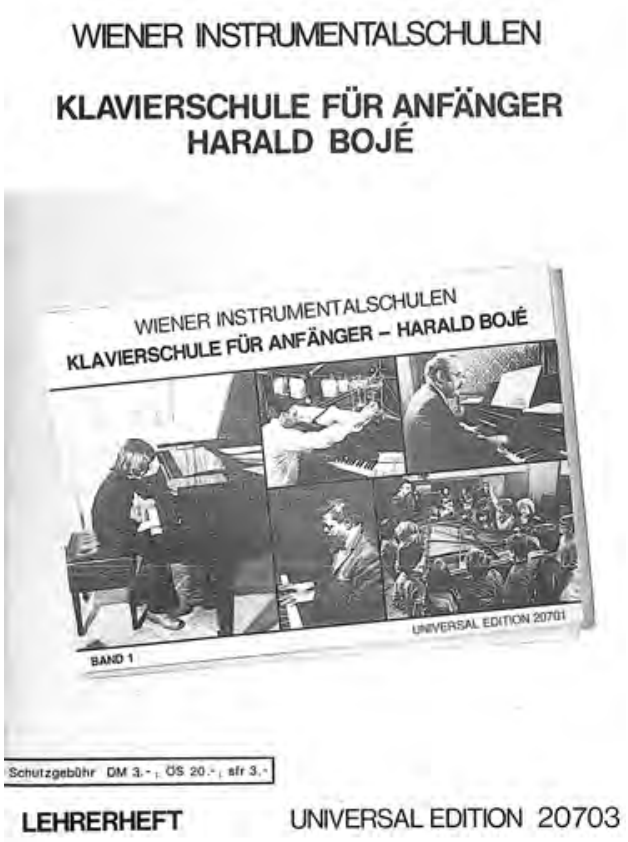

$\mathrm{Na}$ introdução, Harald Bojé declara que seu objetivo principal é desenvolver um trabalho que concilie a musicalização ao piano e o desenvolvimento técnico, possibilitando ao aluno tocar um repertório tanto tradicional como moderno. $\mathrm{O}$ autor sugere que, depois do aprendizado da escrita tradicional, o professor apresente peças da literatura específica de piano para serem estudas paralelamente às peças sugeridas no livro. No mesmo texto, Bojé indica que as criações musicais dos alunos devem ser escritas em grafias inventadas por eles mesmos, para que possam estudar suas próprias músicas em casa, seguindo o que criaram. Ele destaca que a liberdade dada ao aluno para inventar não o isenta de buscar o melhor resultado técnico na execução, e o professor deve orientá-lo nesse estudo (BOJÉ, 1982, p. 3). 
Nas primeiras páginas de Klavierschule für Anfänger, propõe-se uma exploração sonora, física e mecânica do piano, com alguns comandos claros e fotos de crianças como exemplo. Os alunos são incitados a manipular o teclado e o interior do instrumento e perceber os efeitos sonoros dessa exploração, assim como o funcionamento dos martelos e dos pedais. O autor indica, por exemplo, "toque [brinque no] o instrumento, nas teclas com: os dedos, a palma das mãos, cantos da mão, cotovelo, parte anterior dos braços, a quatro mãos etc. No interior: pinçar, bater, esfregar, cantar dentro, tocar trompete dentro etc." ${ }^{24}$ (BOJÉ, 1982, p. 8, tradução nossa).
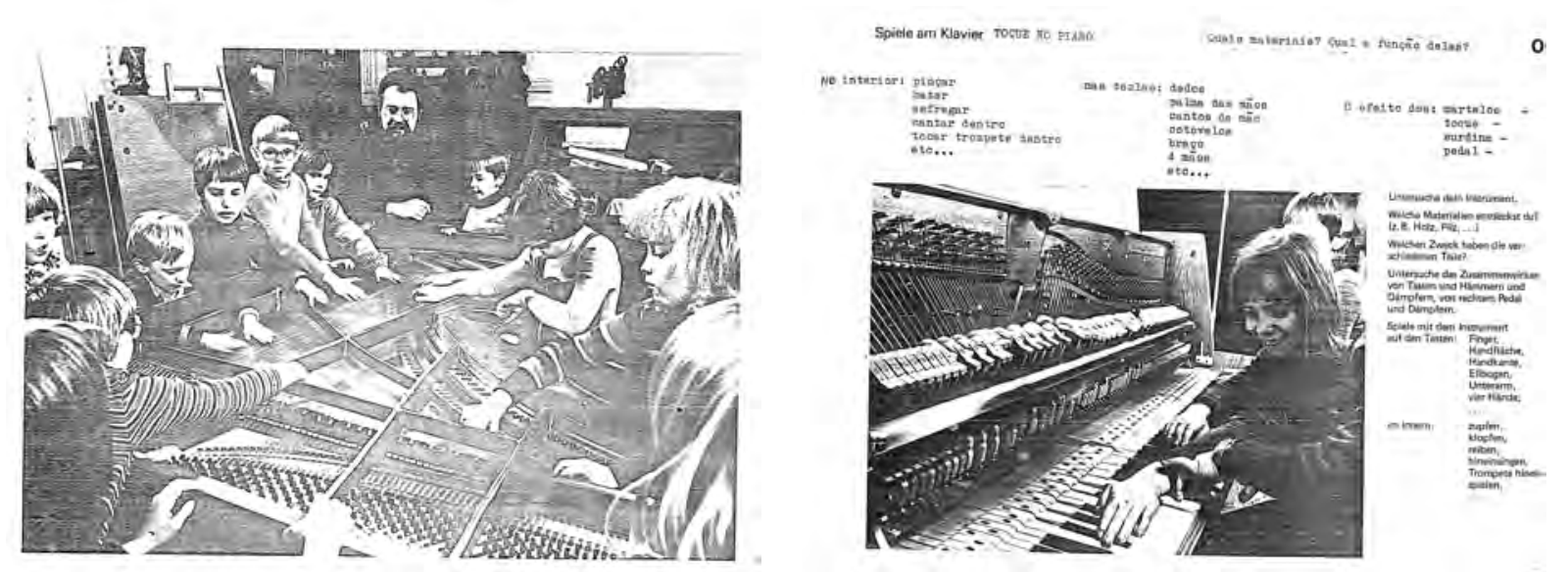

Bojé introduz a leitura desde o começo, não com a escrita tradicional, mas com a notação gráfica. Ele complementa as partituras com o foco de cada música: densidade, volume, localização no teclado (regiões grave, média e aguda), pulso, andamento etc. $\mathrm{O}$ objetivo dessa escrita mais aberta é estimular a imaginação e a criatividade dos alunos, possibilitando-lhes tocar não apenas o que está escrito na partitura (BOJÉ, 1982, p. 3). Logo após a exploração sonora, Bojé apresenta partituras que indicam as regiões aguda, média e grave e a densidade a partir de símbolos que apontam: um tom, um silêncio ou um cluster, e mesmo outros para que a música seja tocada nas cordas, com objetos como escovas, baquetas, pedaços de plástico etc. Em duas das partituras, há a interessante indicação para se tocar por mais de uma pessoa, mas uma delas deve virar o livro e tocar a partitura invertida. Outras sugerem o caráter da peça: "suas mãos se movem nas teclas como um gato, como um elefante, como uma pulga etc." 25 (BOJÉ, 1982, p. 10, tradução nossa).

\footnotetext{
24 “Spiele mit dem Instrument auf den Tassen: finger, handfläche, handkante, ellbogen, unterarm, vier Hände [...]. Im Innern: zupfen, klopfen, reiben, hineinsingen, Trompete hinein-spielen [...]” (BOJÉ, 1982, p. 8).

25 "Deine Hände bewegen sich auf den Tasten: wie eine Katzen, wie ein Elefant, Wie ein Floh [...]" (BOJÉ, 1982, p. 10).
} 


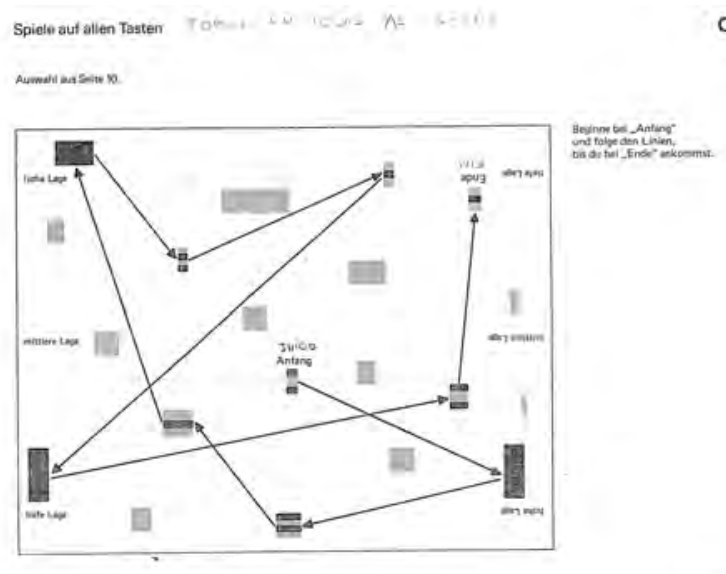

Em algumas peças com notação não convencional, o teclado é apresentado com os nomes das notas escritos nas teclas correspondentes e, logo abaixo, propostas de partituras com a mesma notação, alternando as regiões aguda, média e grave. Propõem-se também a criação de sequências de notas, o exercício de "tirar de ouvido", canções nas teclas pretas e nas teclas brancas e para tocar começando de diferentes notas (transposição prática). Como explicitado na introdução do livro, a escrita tradicional é apresentada entremeada por outras notações, o que revela uma preocupação em formar o aluno nas diversas possibilidades de escrita.

O repertório de peças abarca vários períodos da música centro-europeia, com compositores como Purcell, Rameau, Beethoven e Bartók, além de obras do século XX, melodias tradicionais europeias e mesmo uma inserção no ragtime, com uma peça de Scott Joplin.

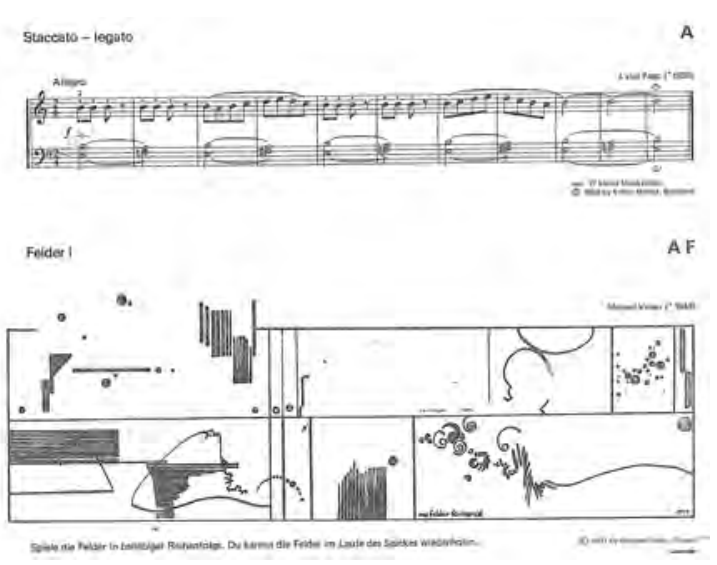


Klavierschule für Anfänger tem uma proposta de iniciação ao piano bastante ampla, com a integração de várias possibilidades de repertório e a valorização das diversas formas de notação musical. A exploração das inúmeras possibilidades timbrísticas do instrumento e a criação são estimuladas desde o começo. Com abordagem bem diferente da dos métodos adotados na década de 1980, e mesmo atualmente, em Klavierschule für Anfänger, Harald Bojé propõe um caminho mais aberto para a iniciação ao piano.

\section{Educação musical através do teclado - Maria de Lourdes Junqueira Gonçalves e Cacilda Borges Barbosa}

Verbete biográfico: Maria de Lourdes Junqueira Gonçalves é pianista, professora de piano, pesquisadora e referência no ensino de piano em grupo, no Brasil. Em 1943, graduou-se como professora de piano na Escola Nacional de Música da Universidade do Brasil, seguindo a carreira docente até se aposentar como professora titular da Universidade Federal do Rio de Janeiro, em 1988.

Nasceu em Ponte Nova, no estado de Minas Gerais, em 1924. Descreve o início de seu aprendizado pianístico: "Embora seja mineira, comecei a estudar 'com professora' em Manaus, AM. Antes, houve um período em que aprendi 'por imitação' com minha irmã mais velha, que, lastimavelmente, faleceu ainda criança. Então, perdi meu 'modelo' e passei a apelar para o ouvido [...]" (GONÇALVES; BARBOSA, [s.d.d]). Sua reeducação pianística iniciou-se em 1938, já no Rio de Janeiro, com a professora Maria Theresa Nunes. Mais tarde, ingressou na Escola Nacional de Música da Universidade do Brasil, onde estudou harmonia com José Siqueira, pedagogia com Sá Pereira e piano com Dulce Saules, todos renomados professores da época. Magdalena Tagliaferro, Lúcia Branco e Ilara Gomes Grosso também fizeram parte de sua formação (GONÇALVES; BARBOSA, [s.d.c]; [s.d.d]).

Lecionou piano desde sua graduação e, paralelamente, desenvolveu projetos de pesquisa voltados para o ensino do instrumento em grupo, tema sobre o qual apresentou trabalhos em congressos. Em 1978, participou do programa de pesquisa Brazilian Lecturer/Researcher Program, nos Estados Unidos, estudando com importantes nomes da educação musical estadunidense como Louise Bianchi, Lynn Freeman Olson, Robert Pace, Frances Clark e Louise Goss. A partir de então, dedicou-se à divulgação da metodologia do ensino de piano em grupo, em cursos na UFRJ e na UNIRIO e em outras cidades brasileiras. 
Gonçalves publicou Ciranda, cirandinha - estudos tonais sobre o cancioneiro folclórico do Brasil e a série Educação musical através do teclado, em coautoria com Cacilda Borges Barbosa.

Verbete biográfico: Cacilda Borges Barbosa nasceu no Rio de Janeiro, em 1914, e faleceu na mesma cidade, em 2010. Foi pianista, professora de piano, maestrina, compositora e pioneira no uso de música eletrônica no Brasil.

Aos 14 anos, ingressou no Instituto Nacional de Música do Rio de Janeiro, onde estudou com renomados profissionais da época como Lima Coutinho, Lorenzo Fernandez, Paulo Silva, Francisco Braga, Paulino Chaves, Francisco Mignone, Maria Figueiró Bezerra, Vera Janacópulos, Ernst Widmer e Sá Pereira (BARBOSA, [s.d.a]).

Na década de 1930, iniciou sua carreira de educadora, participando da equipe dos projetos educacionais de Villa-Lobos, no Serviço de Música e Canto Orfeônico do Rio de Janeiro, fundado pelo compositor em 1932 e que mais tarde passou a se chamar Serviço de Educação Musical, onde Barbosa ocupou o cargo de chefe. Foi a primeira diretora da Escola Popular de Educação Musical e Artística, atual Instituto Villa Lobos do Estado do Rio de Janeiro, e professora na Escola Técnica de Assistência Social Cecy Dodsworthna, na Escola Nacional de Música da Universidade do Brasil e na Escola Popular de Educação Musical. Foi regente de diversos corais e conjuntos orquestrais. Em 1965, criou um nova metodologia na Escola de Dança do Teatro Municipal, a ritmoplastia. Viajou para os Estados Unidos, pela Europa e pela Ásia, onde teve contato com novos métodos de ensino musical, publicando livros didáticos como a coleção Diorama, Estudos brasileiros para piano, Estudos brasileiros para canto e piano e, com Maria de Lourdes Junqueira Gonçalves, Educação musical através do teclado (DICIONÁRIO [...], [s.d.]).

Iniciou sua carreira artística como pianista popular, tocando valsas e chorinhos em bailes da noite carioca. Nos anos 1950, foi maestrina da orquestra da rádio Mayrink Veiga. Como compositora, Barbosa teve sua primeira peça publicada em 1928, a valsa Cruzada azul. Entre suas principais obras estão Chibraseando, Cota zero, Lamentações onomatopaicas, Missa em fugas, Segunda missa brasileira, Uirapiranga (DICIONÁRIO [...], [s.d.]). 


\section{Educação musical através do teclado}

Em 1985, Maria de Lourdes Junqueira Gonçalves e Cacilda Borges Barbosa publicaram Educação musical através do teclado como "resultado de programa de pesquisa sobre a metodologia do ensino de piano em grupo, iniciado na UFRJ e concluído na UNIRIO” (GONÇALVES, 1989, p. vi). Pensado originalmente para o ensino em grupo, também pode ser usado em aulas individuais.
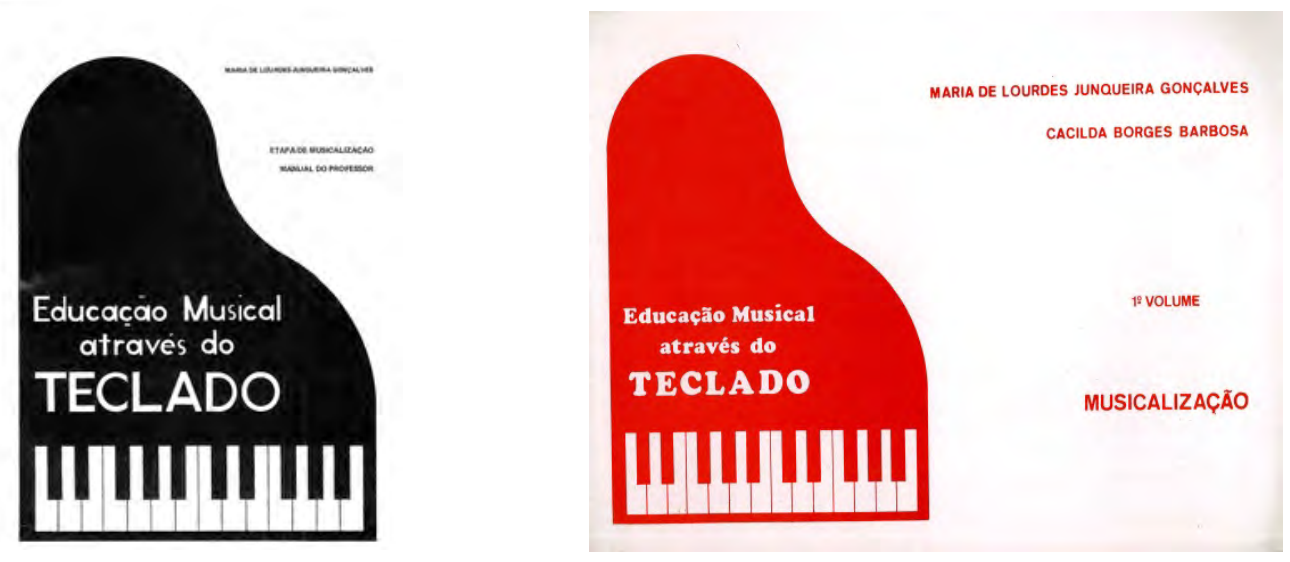

A série tem 4 volumes: Musicalização, Leitura nas teclas brancas, Leitura nas teclas brancas e pretas e Habilidades funcionais, e cada um conta com o livro do aluno e o manual do professor.

No primeiro volume do manual do professor, Gonçalves explicita que o foco da série é integrar execução, criação e audição no processo de ensino e aprendizagem do piano, procurando desenvolver a musicalidade do aluno através do teclado e não se limitando, "como no ensino tradicional do piano, a oferecer prática de técnica e repertório" (1989, p. v-vi).

A autora parte do pressuposto de que a educação musical deve ser oferecida a todos, sem foco na profissionalização, e que o piano deve ser reconduzido "a sua condição de instrumento a serviço da Música e não apenas a serviço do virtuose" (GONÇALVES, 1989, p. $\mathrm{v}$, grifos do original), criticando o ensino tradicional de piano daquela década, voltado à formação de virtuoses, e que ainda hoje é bastante frequente. 
No manual do professor, apresentam-se sinteticamente as referências históricas e diversas orientações didáticas e práticas para o ensino em grupo. O método valoriza o protagonismo do aluno, mas lembra ao professor sua posição de líder ao instruí-lo:

- seja um membro do grupo, mais experiente [...] nem sempre liderando [...] mas se necessário, não hesite em lembrar, com certa energia, que o grupo tem um líder e que este líder é o professor. [...];

- ouça com respeito o que o aluno diz ou toca mas quando necessário, encurte, sutilmente, o "discurso" ou as "Variações Goldberg" que porventura surjam, entre as composições;

- faça perguntas claras, busque o diálogo, a discussão em grupo mas não deixe que a discussão se alongue ao ponto de perturbar o ritmo da aula;

- não "ensine" sempre. Deixe que se ensinem, uns aos outros mas não acuse a "cola". Muitas vezes as crianças aprendem melhor umas com as outras do que com o professor [...] (GONÇALVES, 1989, p. 10-11).

Os livros do aluno são sequenciais e os conteúdos são apresentados segundo uma abordagem em espiral, isto é, os conceitos são retomados a cada livro, porém com maior profundidade. Cada livro aborda notações convencionais e não convencionais, aprendizagem de conceitos musicais e prática de habilidades funcionais com ênfase na leitura. Em relação à criatividade, Gonçalves valoriza a criação como forma de expressão do aluno e também como recurso do professor para verificar os conceitos que o aluno já interiorizou.

Considerando que "a leitura é o resultado da experiência musical, e não uma condição para tal experiência" (GONÇALVES, 1989, p. 15), desenvolve-se a leitura desde o primeiro volume, a partir de uma notação não convencional, com o objetivo de criar o hábito de alternar o olhar entre a partitura e a mão, e não somente como uma preparação para a leitura tradicional.

O método começa com o conhecimento da topografia do teclado, movimentando amplamente mãos e braços, com as mãos em posição de cluster nas teclas pretas e brancas. Com movimentos ascendentes e descendentes e trabalhando a noção de duração, o aluno é estimulado a tocar no teclado todo. Há canções tradicionais brasileiras e de outros países com indicação de ritmo e da posição inicial no desenho do teclado e propostas de composição a partir de determinados elementos musicais. 

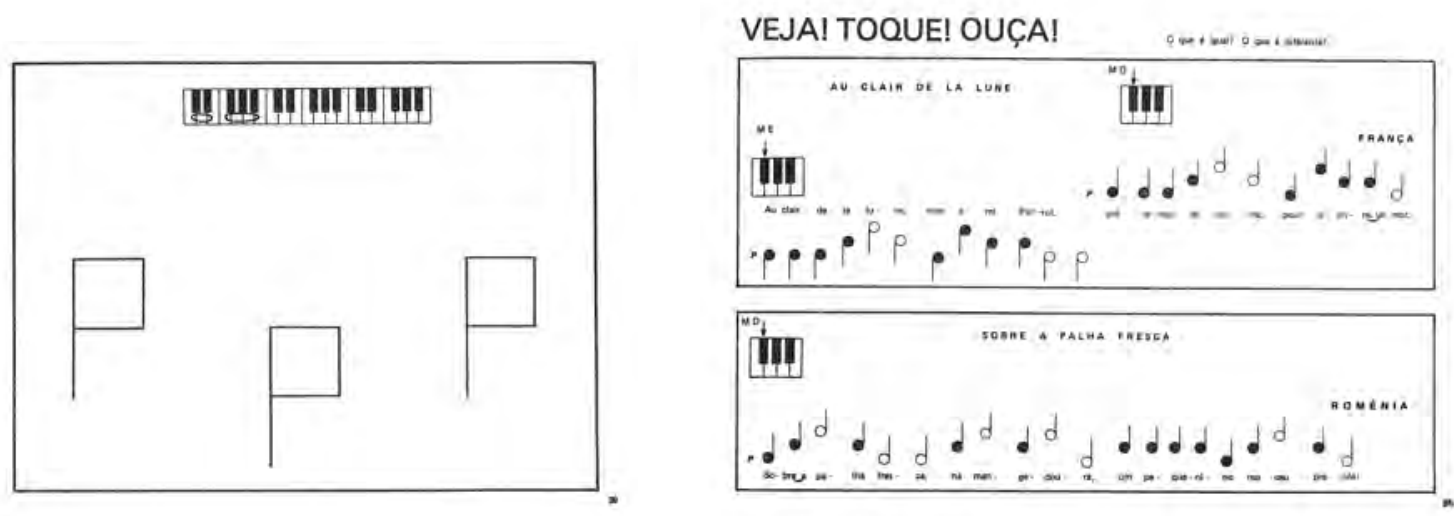

Ainda no primeiro volume, as autoras propõem um trabalho de pré-leitura, com o objetivo de preparar a leitura por intervalos que é desenvolvida no segundo volume. Embora a ênfase esteja na leitura, há também propostas de composição.
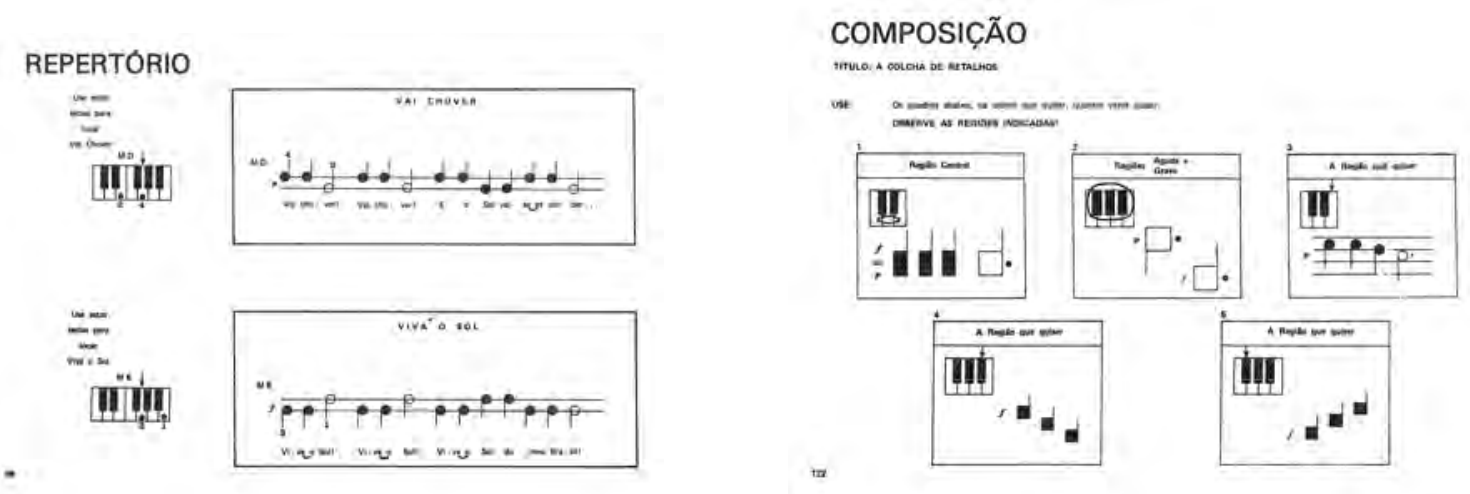

O foco do terceiro volume é a pluralidade musical. "Ao terminar este volume, em termos de idiomas musicais, a criança já terá experimentado um pouco de música aleatória, com notação convencional ou não, um pouco de música hexatônica, cromática, pentatônica ou diatônica" (GONÇALVES; BARBOSA, [s.d.a]).

O quarto volume desenvolve habilidades funcionais no teclado: tocar por imitação, ler partituras e cifras, transpor e criar. Conceitos como modo maior e menor, escalas diatônicas etc. são apresentados ou revisados (GONÇALVES; BARBOSA, [s.d.b]).

Segundo análise, a série Educação musical através do teclado valoriza o espaço da criação, o que era inovador na década de 1980. Ainda hoje, ressentimo-nos de métodos brasileiros que, assim como esse, propõem criações dos alunos, introduzem notações não convencionais e a noção de harmonia e estimulam a leitura de cifras, abrindo caminho para a música popular. 


\section{Atenção! Crianças compondo - Fernanda Fontoura}

Verbete biográfico: Fernanda Tarrisse da Fontoura é pianista e professora de piano. Graduada pela Universidade Federal do Rio Grande do Sul, busca novos caminhos para a educação musical pelo piano desde o início de sua atuação profissional (informação pessoal).

Fontoura nasceu em 1955, em São Leopoldo, no Rio Grande do Sul. Estudou com Arnaldo Estrella e Radamés Gnattali, no Rio de Janeiro, e com a pedagoga argentina Violeta de Gainza, participando de cursos, seminários, congressos no Brasil e Argentina. Em 1986, fundou a Oficina de Música, em Porto Alegre (RS), onde lecionou até 1996 (informação pessoal).

Em 1999, gravou o CD autoral Brasilian Heartbeat, com direção musical de Toneco da Costa. Participou de master classes com Roberto Szidon, Sebastian Benda, Luiz de Moura Castro, Nadeja Eysmont, José Henrique Martins, Lucia Barrenechea, entre outros. Atualmente, trabalha no Brasil e na Bolívia, dedicando-se à música de câmara e a projetos que levam a música aos jovens e às comunidades carentes através de concertos didáticos (informação pessoal). ${ }^{26}$

\section{Atenção! Crianças compondo}

Atenção! Crianças compondo foi publicado em 1993, pela Editora Metrópole, em Porto Alegre. O livro é uma coletânea de composições de crianças, resultado do trabalho desenvolvido com os alunos de piano da autora, que tinham entre 5 e 14 anos de idade.

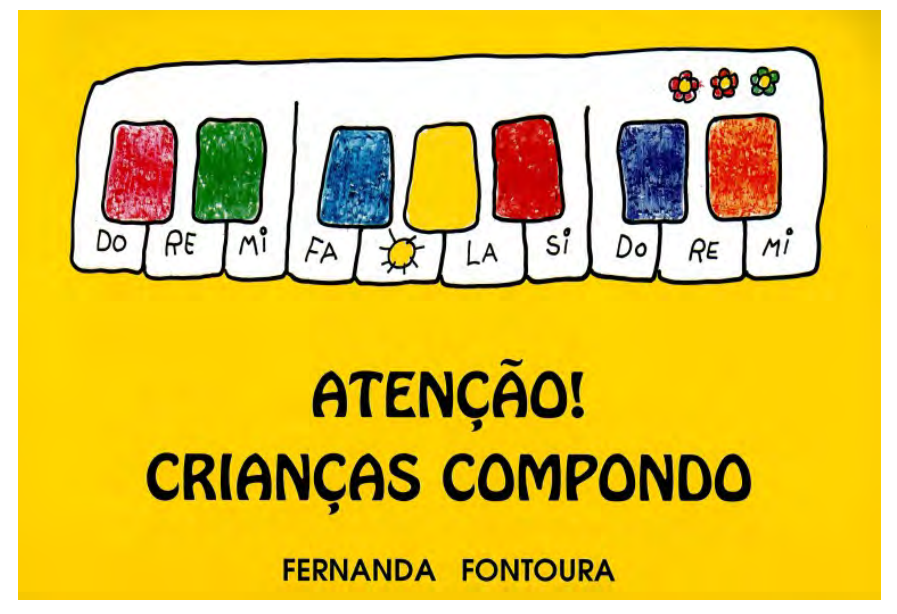

\footnotetext{
${ }^{26}$ Fontoura, F.T. Dados biográficos. Mensagem recebida por beremusica@ gmail.com em 27 mai. 2014.
} 
Fontoura (1993, p. 7) resume sua motivação para publicar o livro em uma "urgência de mudança", que teria se manifestado na busca por "um caminho diferente para a iniciação musical através do piano. Um caminho no qual seja fundamental criar. Onde tudo o que se aprende seja motivo de criação”. Segundo a autora, quando o aluno cria sobre o que estudou, o conhecimento é sedimentado, e há unidade entre seu mundo sonoro interno e externo, que precisam estar equilibrados.

Palitos chineses, de Violeta de Gainza, foi disparador do trabalho com seus alunos, que, ao estudar músicas criadas por crianças, se sentiram incitados a criar suas próprias composições. "Os pequenos alunos de Violeta de Gainza tocaram os mistérios, as emoções e as fantasias das crianças" (FONTOURA, 1993, p. 8).

As composições dos alunos de Fontoura foram inspiradas em alguma peça estudada por eles, como as músicas de Palitos chineses, algumas das 24 peças op. 39, de Dimitri Kabalevsky, uma peça de Jazz Exercise, de Oscar Peterson, e outras composições que traziam um elemento musical que instigava a criação como um intervalo de meio tom, o pentacorde de Dó Maior, as primeiras notas estudadas etc.

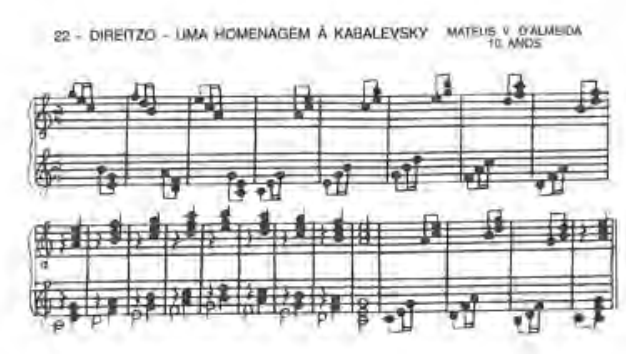

O livro adota a escrita tradicional, mas as peças até a número 8 têm o desenho do teclado e um código inventado pelos próprios alunos, facilitando o aprendizado da música por aqueles que ainda não se apropriaram da escrita musical tradicional. Em algumas peças, há indicação da escala usada, de um intervalo predominante na maior parte da peça ou mesmo um baixo ostinato para acompanhamento. 

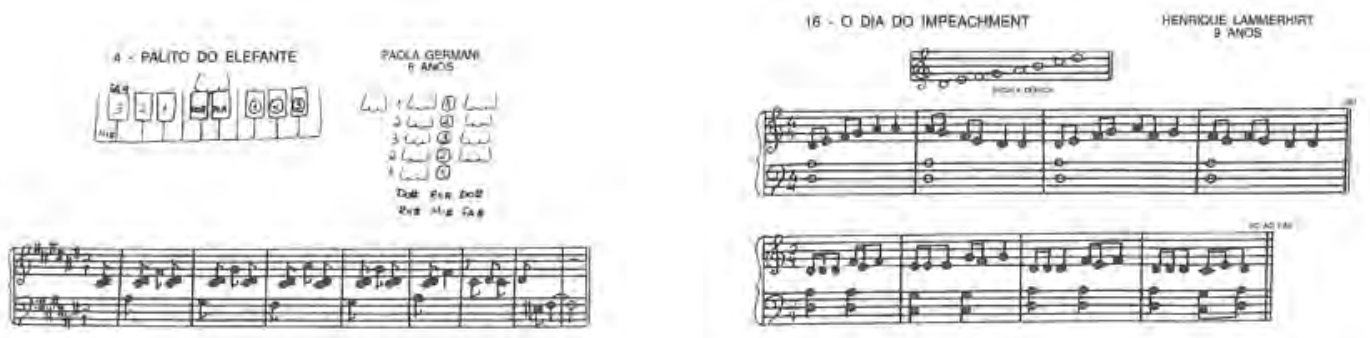

Atenção! Crianças compondo não é só uma coletânea de composições de crianças, mas também uma proposta bem estruturada de se introduzir a criação no aprendizado do piano. Ao analisarmos as peças, reconhecemos conceitos musicais trabalhados pelos alunos como a escala usada (em $O$ dia do impeachment e $A$ vida no deserto, por exemplo) ou a forma musical da composição (Palitos rondozitos, Tema com variações). Como afirma Fontoura (1993, p. 7), "a melhor forma de avaliarmos o conhecimento de um aluno é fazê-lo criar sobre o tema estudado".

O livro é um estímulo para os professores de piano serem mais criativos em suas aulas, o que também pretendia Gainza ao publicar Palitos chineses: “[...] eu estava implicitamente buscando interlocutores que compreendessem minha mensagem e a tornassem sua própria e a transmitissem" (GAINZA apud FONTOURA, 1993, prefácio). Creio que, com esse livro, Fontoura se tornou interlocutora de Gainza.

\section{Piano 1 e 2: arranjos e atividades - Ana Consuelo Ramos e Gislene Marino}

Verbete biográfico: Ana Consuelo Ramos é pianista, educadora musical, pesquisadora e autora de diversos artigos acadêmicos. É professora da Escola de Música da Universidade do Estado de Minas Gerais (ESMU-UEMG) desde 1995, e, atualmente, leciona Piano complementar (para cantores), no bacharelado, Piano em grupo, no curso de Musicalização Infantil, e Metodologia do Ensino do Instrumento-Piano, nos cursos de licenciatura e bacharelado em Música e no curso de especialização, além de orientar trabalhos de conclusão de curso (RAMOS, 2014).

Ramos também é pesquisadora no Grupo de Estudo e Pesquisa em Educação Musical: interfaces com a educação e a sociedade (GEPEMUS), principalmente na área de Processos 
de Ensino e Aprendizagem Musical em Diferentes Contextos. Entre 2000 e 2012, foi coordenadora do Curso de Musicalização Infantil e do Projeto Música Comentada, supervisora do Estágio Curricular do bacharelado em Música, chefe do Departamento de Comunicação e Expressão Artística e do Departamento de Formação Pedagógica.

Ana Consuelo Ramos nasceu em Manhuaçu, em Minas Gerais. Aos 7 anos de idade, iniciou seus estudos de música em aulas particulares, em Peruíbe (SP). Estudou piano com Regina Amaral, Maria Lúcia Coutinho Collen e Maria Lígia Becker, e didática do piano com Tânia Cançado e Berenice Menegale. Em paralelo, fez cursos com nomes importantes do cenário da educação musical como Hans-Joachim Koellreutter, Violeta de Gainza e Keith Swanwick (informação pessoal). Em 1994, graduou-se bacharel em Música na Escola de Música da Universidade Federal de Minas Gerais (EMUFMG) e, em 2001, especializou-se em Música Brasileira - Práticas Interpretativas, na Escola de Música da Universidade do Estado de Minas Gerais (ESMU-UEMG). É mestre em Música pela Escola de Música da Universidade Federal de Minas Gerais (EMUFMG) e, atualmente, é doutoranda em Educação pela Pontifícia Universidade Católica de Minas Gerais.

Como professora de piano, interessa-se especialmente por temas como ensino de piano em grupo, ensino do piano como instrumento complementar e introdução à leitura musical ao piano (informação pessoal). ${ }^{27}$

Verbete biográfico: Gislene Marino é pianista, educadora musical e autora de diversos artigos acadêmicos. Desde 1995, é professora dos cursos de licenciatura em Música e nos de pós-graduação Lato Sensu da Escola de Música da Universidade do Estado de Minas Gerais (ESMU-UEMG), onde também rege um dos corais infantis do curso de Musicalização Infantil. Entre 1997 e 2012, foi chefe do Departamento de Teoria Musical, coordenadora do bacharelado em Música e de Musicalização Infantil, e diretora da ESMU-UEMG. Lecionou no ensino fundamental nas redes pública e privada (MARINO, 2014).

Gislene Marino nasceu em Belo Horizonte (MG). Iniciou seus estudos de piano aos cinco anos de idade e, mais tarde, estudou com Tânia Cançado, Magdala Costa e Eduardo Hazan. Fez cursos com nomes importantes do cenário musical como Keith Swanwick, em educação musical, e Cláudio Dauelsberg, em improvisação na música popular

\footnotetext{
${ }^{27}$ Ramos, A.C. Texto. Mensagem recebida por beremusica@ gmail.com em 6 fev. 2014.
} 
contemporânea. Ao lado de seus estudos na área musical, fez cursos de gerência e gestão pública para apoiar sua atuação em funções administrativas na ESMU-UEMG.

Em 1986, concluiu os cursos de bacharelado em Música-Piano e de licenciatura em Música e, em 1993, especializou-se em Educação Musical, na Escola de Música da UEMG. Em 2005, tornou-se mestre em educação pela Faculdade de Educação da UFMG (informação pessoal). ${ }^{28}$

\section{Piano 1 e 2: arranjos e atividades}

Piano 1: arranjos e atividades e Piano 2: arranjos e atividades, da coleção Inventos e canções, foram publicados pelas próprias autoras, em Belo Horizonte, em 2001 e 2009, respectivamente. Os dois são adotados no curso de Musicalização Infantil da ESMU-UEMG e já foram apresentados em vários eventos como I e II Encontro de Pesquisa e Metodologia Científica da UEMG (2000 e 2001), XIII Encontro Nacional da ANPPOM (abril de 2001), XI Encontro Anual da ABEM (outubro de 2001 e 2002); XVI Encontro Anual da ABEM e Congresso Regional da International Society for Music Education (ISME) na América Latina (outubro de 2007), $8^{\circ}$ Encuentro de la Canción Infantil Latinoamericana y del Caribe (outubro de 2007, na região de Valparaíso, no Chile) e II Colóquio de Pesquisa da ESMU-UEMG (novembro de 2007 em Belo Horizonte-MG).
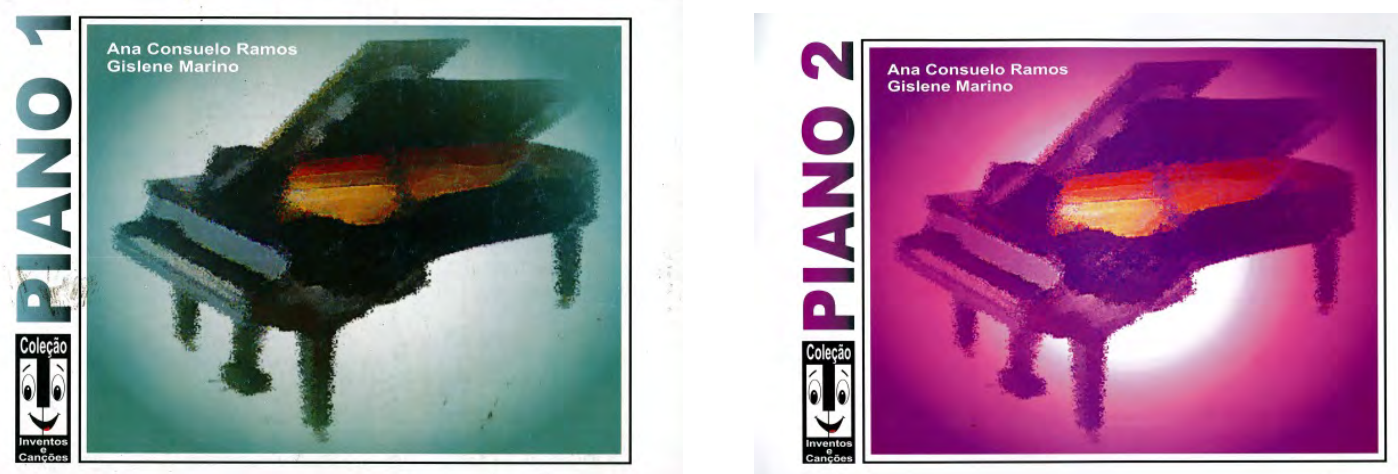

Piano 1 foi elaborado a partir de pesquisas e da experiência das autoras em sala de aula. A concepção do piano como um instrumento musicalizador e uma pedagogia que integre teoria e prática são as linhas mestras do material. O livro destina-se ao ensino de crianças

\footnotetext{
${ }^{28}$ Marino, G. Texto. Mensagem recebida por beremusica@gmail.com em 6 fev. 2014.
} 
entre 7 e 10 anos, em aulas particulares ou em grupo. Marino e Ramos (2001, p. xiii) explicam sua estrutura básica:

[Há] duas partes - a do professor e a do aluno - que são apresentadas simultaneamente, estando a do professor nas páginas à esquerda e a do aluno à direita. A seção direcionada ao professor expõe os objetivos de cada atividade, apresenta considerações e orientações que fundamentam nossa proposta e sugere atividades complementares com a finalidade de auxiliá-lo e estimulá-lo à criação de outras.

Os dois volumes seguem a mesma linha didática, mas têm focos diferentes. O primeiro concentra-se no contato com o instrumento, deixando de "limitar-se à técnica e repertório, abrindo espaço para vivências musicais através da exploração do teclado, de improvisações e canções tocadas por imitação e por audição" (MARINO; RAMOS, 2001, p. xiii). Piano 2 foi pensado para alunos que já têm algum conhecimento musical e procura "ampliar o material musical para o ensino de piano em grupo - três alunos no mesmo instrumento -, focalizando a linguagem tonal, com ênfase nos pentacordes maiores e menores e nas escalas maiores" (MARINO; RAMOS, 2009, p. xvii).

O primeiro volume está estruturado em seis capítulos: "O piano", "Efeitos sonoros", “Teclas pretas/ Canções por imitação", "Teclas brancas e pretas/ Leitura por gráfico", "Canções de dois e três sons/ Figuras musicais/ Leitura relativa" e "Grupo de três sons/ Figuras musicais/ Leitura absoluta" (MARINO; RAMOS, 2001, p. xv). Já pelo título dos capítulos percebe-se que o foco das atividades é o conhecimento e a exploração sonora das partes do piano e uma breve história do instrumento. Na primeira parte do livro, explora-se a escrita não convencional, com gráficos e outras formas de notação, e a escrita tradicional é introduzida somente na segunda parte. Trabalham-se canções aprendidas por imitação, por audição e por leitura gráfica, relativa e absoluta.

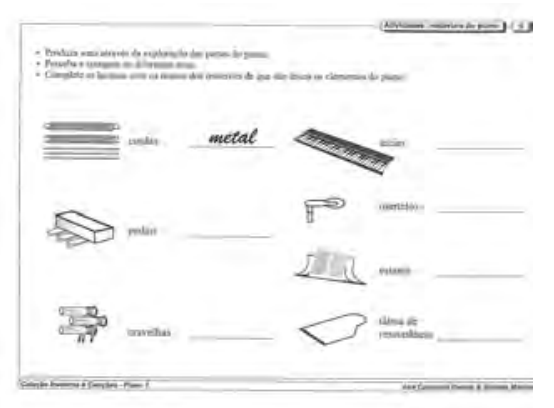



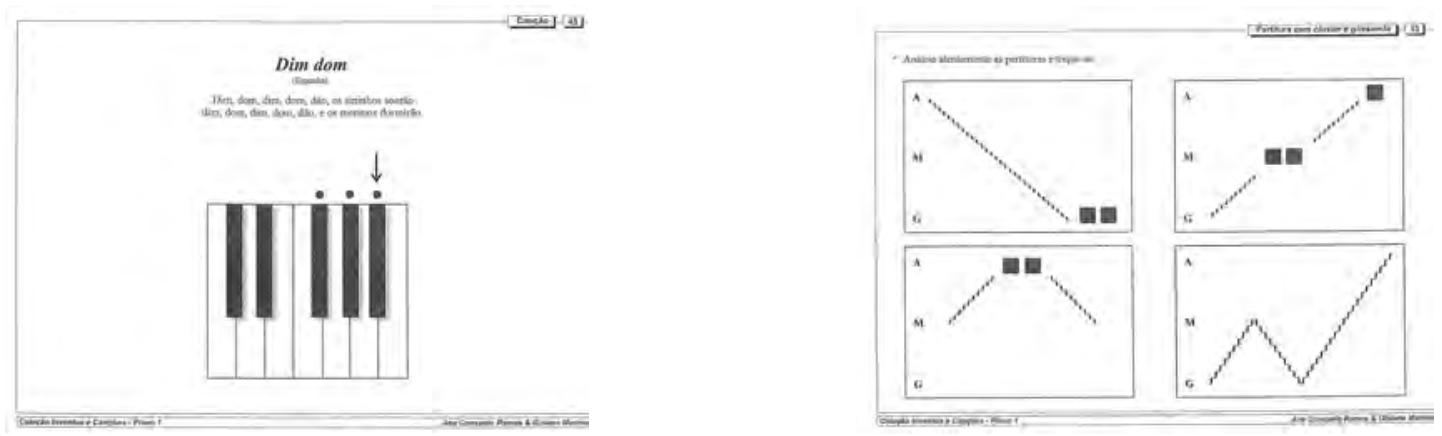

Nas considerações gerais, as autoras detalham os eixos norteadores do livro, dando sugestões de como trabalhar, nas aulas de piano em grupo, o aspecto técnico, a leitura à primeira vista, a improvisação e a criação.

O segundo volume apresenta composições das autoras, canções folclóricas brasileiras e de outros países e atividades de apoio à musicalização, além de improvisações: "Os conceitos musicais são introduzidos por meio do repertório, acrescentando-se sugestões de práticas pedagógicas como a composição ou improvisação, a apreciação e a aprendizagem de músicas por audição e por imitação" (MARINO; RAMOS, 2009, p. xvii).

Esse livro está estruturado em cinco capítulos: "Pentacordes maiores", "Pentacordes menores", "Escalas maiores", "Cifras" e "Outras escalas". O pentacorde é o foco desse volume e é trabalhado de acordo com a abordagem multitonal, o padrão dos cinco dedos (five finger patter), surgida nos Estados Unidos para o ensino de piano em grupo e difundida por autores como Robert Pace, Violeta de Gainza, Maria de Lourdes Junqueira Gonçalves, Marienne Uszler e Marion Verhaalen. Segundo as autoras, "a aprendizagem dos pentacordes favorece o desenvolvimento de habilidades para escuta e transposição de melodias" (MARINO; RAMOS, 2009, p. xx).
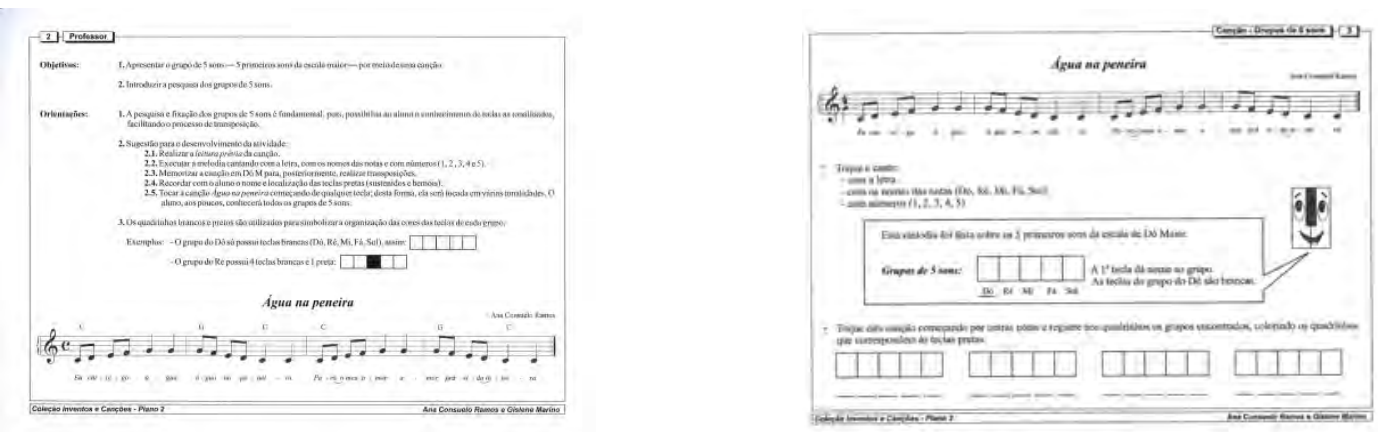
O método se baseia nos princípios do modelo $\mathrm{C}(\mathrm{L}) \mathrm{A}(\mathrm{S}) \mathrm{P}$, de Keith Swanwick, ${ }^{29}$ e as propostas de composição se apresentam a partir de improvisações, presentes desde as primeiras páginas.
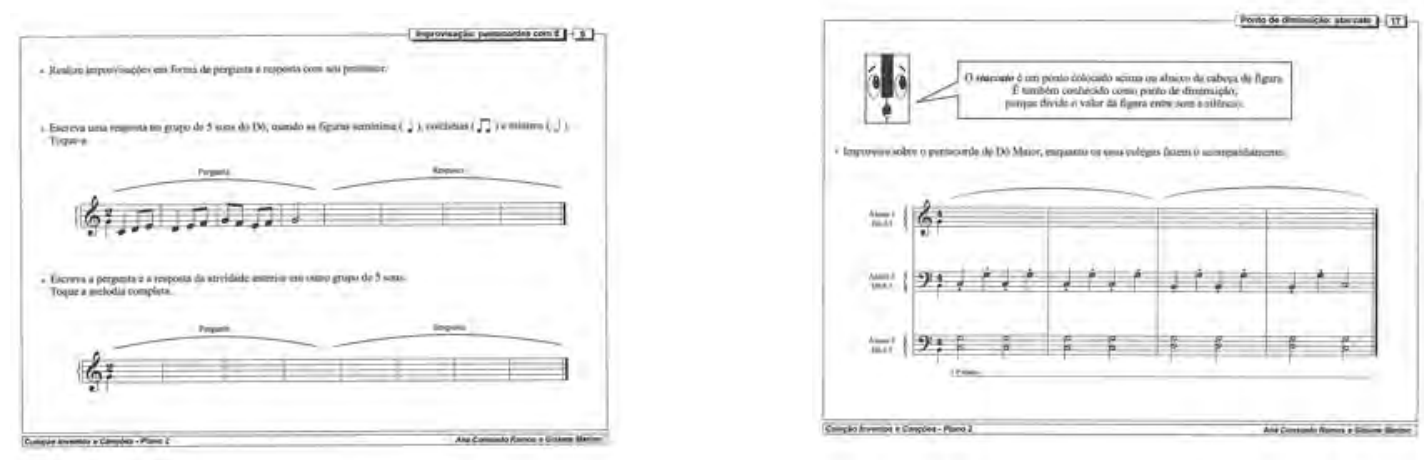

Após a análise dos livros para piano de Ana Consuelo Ramos e Gislene Marino, identificamos sua preocupação em desenvolver um ensino de piano mais contemporâneo, que não se limite a peças musicais em dificuldade progressiva e exercícios de técnica, mas que abra espaço para a criatividade, deixando o aluno explorar sonoramente e se musicalizar através do piano e que ensine conceitos musicais com a prática de composição, improvisação, apreciação e execução por leitura, audição e imitação. Faço minhas as palavras do pesquisador Marcelo Almeida Sampaio (2001, p. 97), que, ao analisar Piano 1 em sua dissertação de mestrado, considera que o material valoriza o fazer musical e coloca o aluno como "participante ativo da prática musical e da construção da aula [...] tornando as experiências musicais interessantes e diversificadas e o ensino-aprendizagem criativo e prazeroso", afirmação que pode ser estendida ao segundo volume.

\section{Divertimentos - Laura Longo}

Verbete biográfico: Laura Longo é educadora musical e pianista. Atualmente, é professora de piano na Escola Municipal de Iniciação Artística do Departamento de Expansão Cultural da Secretaria de Cultura de São Paulo (EMIA-DEC-SMC) e mestranda em Música na Universidade de Campinas (UNICAMP). Há alguns anos, ministra palestras e cursos para

\footnotetext{
${ }^{29} \mathrm{O}$ modelo C(L)A(S)P foi proposto pelo compositor e educador musical Keith Swanwick, em seu livro A basis for music education, publicado em 1979 por NFER-NELSON Publishing Company Limited, em Oxford (Reino Unido). Trata-se de uma proposta de desenvolvimento musical a partir de atividades inter-relacionadas de composição, apreciação, performance, literatura musical e habilidades técnicas. A sigla em inglês significa Composition, Literature Studies, Apreciation, Skill acquisition, Performance.
} 
professores em eventos, congressos, escolas de música e universidades tais como UNICAMP, UFAL, UNESP de São José do Rio Preto e Faculdade Santa Marcelina (LONGO, 2013).

Longo nasceu em 1969, na cidade de Martinópolis, em São Paulo, mas morou grande parte de sua vida em Presidente Prudente, onde iniciou seus estudos de piano no conservatório local. Teve seu primeiro contato com o piano observando suas irmãs que estudavam o instrumento; curiosa, intuitivamente e com alguma ajuda das irmãs, começou a experimentar no teclado e a ler partituras. Desde então, o piano passou a ocupar um lugar maior em sua vida (informação verbal).

Em São Paulo, estudou com o pianista Alfredo Cerquinho de 1986 a 1992. Graduou-se bacharel em piano pela Universidade de São Paulo (USP) sob orientação de Gilberto Tinetti, de 1988 a 1991. Em 1993, fez aperfeiçoamento pianístico com Carlo Bruno na Scuola Di Musica T Ludovico da Victoria, na Itália (LONGO, 2013). Ao retornar ao Brasil, foi aluna da pianista Maria José Carrasqueira, durante dois anos (informação verbal).

Por não estar completamente satisfeita com os princípios da educação musical tradicional, buscou aperfeiçoar sua prática pedagógica e ampliar seus conhecimentos musicais. Fez cursos na área pedagógico-musical, obtendo "uma visão pedagógica mais ampla na formação musical dos alunos" (informação verbal). Dentre esses cursos, destacamse os referentes às metodologias Dalcroze, Orff, Kodály e Suzuki, tendo sido aluna de Violeta de Gainza, H. J. Koellreutter, Iramar Rodrigues, Verena Maschat, Maria Ördog, Judith Akoschky, Arnolfo Borsacchi, Lydia Hortélio, entre outros (LONGO, 2013).

De 1994 a 2013, deu aulas de piano, musicalização, percepção e rítmica e orientou grupos infantojuvenis de música de câmara e instrumental Orff na Universidade Livre de Música Tom Jobim - EMESP Tom Jobim, no Conservatório Musical Brooklin Paulista, na Teca Oficina de Música e no Instituto Baccarell (LONGO, 2013).

Dedicada ao ensino de piano individual e em grupo, Longo considera fundamental propiciar aos alunos diversas possibilidades de realização musical, como ler a partitura, tocar de ouvido, criar suas próprias músicas, tornando prazerosa a relação do aluno com a música e com o instrumento (informação verbal). ${ }^{30}$

\footnotetext{
${ }^{30}$ Informações fornecidas por Longo em São Paulo, em 2014.
} 


\section{Divertimentos}

Divertimentos é um livro de peças para piano publicado por Laura Longo, em 2003. Segundo a autora, a motivação primeira para a composição das peças foi sua observação dos métodos tradicionais de iniciação ao piano, nos quais pôde constatar que, em sua grande maioria, faltava ludicidade e criatividade, prevalecendo um direcionamento à leitura de notas desde o princípio. Diante disso, sua proposta foi criar peças tecnicamente fáceis, que iniciantes poderiam aprender mesmo que ainda não tivessem se apropriado da leitura tradicional (LONGO, 2003, p. 11). Apesar de reconhecer a importância da leitura e do desenvolvimento técnico desde o início do aprendizado, Longo aponta a relevância de outros aspectos musicais como sensibilidade, percepção, memória, conhecimento do teclado como um todo e interpretação.

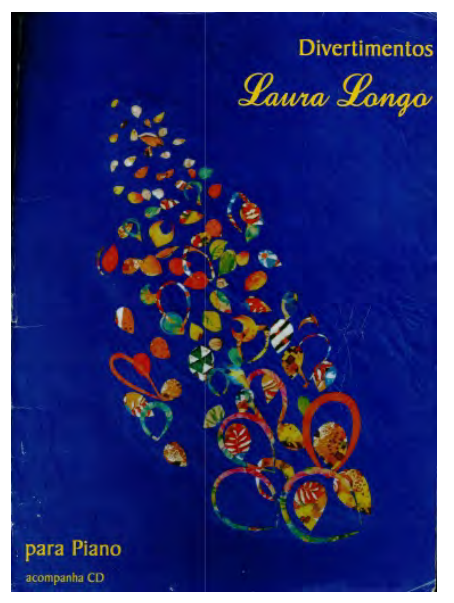

O livro tem 23 peças e é acompanhado por um CD com a gravação de todas as músicas interpretadas pela autora. É possível notar que há progressão de dificuldade técnica e a preocupação de se usar "a extensão do piano, diversos tons e modos e variedade melódica e rítmica" (LONGO, 2003, p. 11).

Todas as peças são escritas no pentagrama e, algumas, no final do livro, também em escrita gráfica, para estimular o uso de notações não convencionais. A ideia básica da autora é apresentar a partitura como um roteiro amplo, possibilitando ao aluno se aproximar da escrita tradicional, mesmo ainda sem ter as informações necessárias para ler todos seus detalhes. 

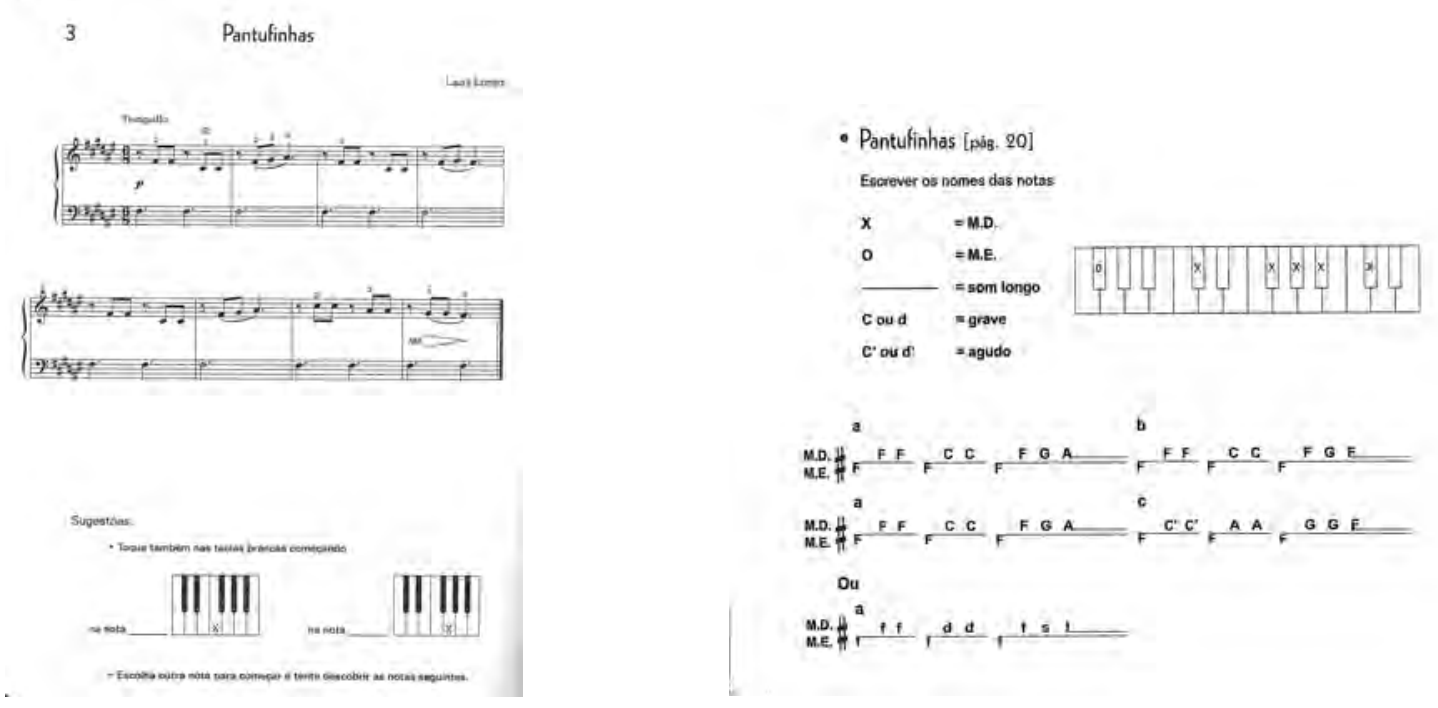

Longo parte do princípio de que o aluno iniciante consegue decifrar vários aspectos musicais na partitura e deveria ser estimulado a isso; os trechos que ele não tem condições de decodificar podem ser aprendidos por imitação. Outro processo que se incentiva é aprender uma música por imitação e, depois, observar e analisar a partitura, identificando o que tocou. Dessa forma, o aluno vai se familiarizando com o código de forma lúdica, tendo uma ideia global da partitura, e, aos poucos, associando intelectualmente som e escrita. Por fim, Longo ressalta que a proposta de imitação não deve ser encarada como simples repetição, mas como um trabalho de percepção das frases e partes da música por meio da imitação auditiva e visual (informação verbal). ${ }^{31}$

A cada peça, sugere-se que o aluno improvise determinados compassos, crie uma melodia para o acompanhamento dado, transponha começando a música em outras teclas, crie variações, mude as articulações, entre outras propostas criativas.

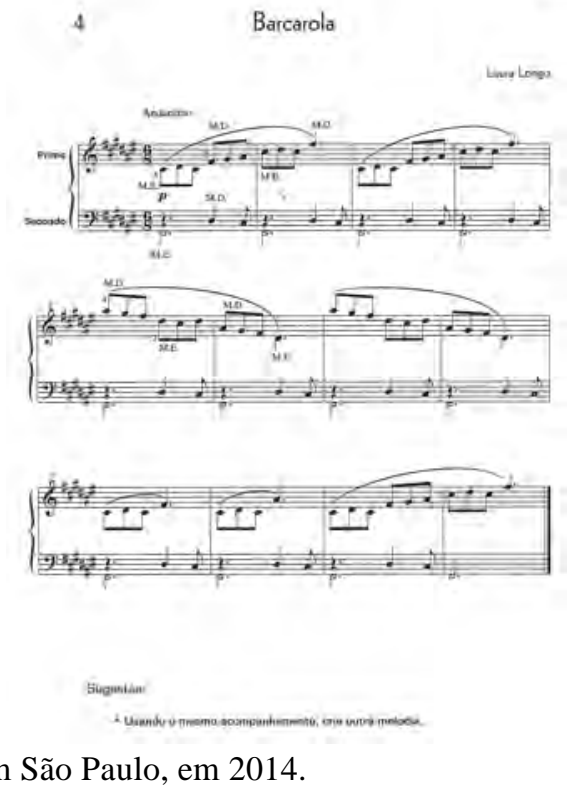

\footnotetext{
${ }^{31}$ Informação fornecida por Longo em São Paulo, em 2014.
} 
A partir da análise e de experiência própria do uso do livro com meus alunos, considero que Divertimentos não se resume a um conjunto de composições, mas amplia as possibilidades de um desenvolvimento musical criativo, conduzido pelo aprendizado das peças apresentadas. Além disso, a criação propriamente dita também é estimulada com as sugestões ao final das peças para que o aluno crie variações e mesmo novas linhas melódicas.

\section{De tecla en tecla - María José Zabala e Mirian Tuñez}

Verbete biográfico: (informação pessoal) ${ }^{32}$ Mirian Tuñez é pianista, educadora musical e professora de piano. Nasceu na cidade de Mar del Plata, Argentina, em 1955. Iniciou seus estudos musicais aos 8 anos e, mais tarde, prosseguiu seus estudos com Silvia Malbrán, Antonio de Raco, Perla Brúgola, Alejandro Ntaca, Violeta de Gainza e Favio Shifres.

Em 1983, graduou-se em Música, na Facultad de Bellas Artes de la Universidad Nacional de La Plata (UNLP), onde, posteriormente, tornou-se docente, ministrando aulas de introdução à leitura pianística e aulas de piano, no curso de bacharelado. Atualmente, é mestranda em Tecnología de Informática aplicada à Educação.

Tuñez foi chefe de departamento, coordenadora de Instrumento e coordenadora de extensão no Departamento de Discursos Musicais do bacharelado de Bellas Artes, UNLP.

Há alguns anos, dedica-se à formação de professores fora da universidade, em cursos de capacitação nos conservatórios de Chascomús, San Luis e Bahía Blanca, e ministra oficinas sobre experiências iniciais na aprendizagem do piano, em encontros e jornadas de arte.

Paralelamente às atividades docentes, escreve artigos e trabalhos para revistas, como Ideas para una nueva educación I y II e Bachillerato de Bellas Artes, publicados na revista científica da Faculdade de Bellas Artes Arte e investigación, e apresenta em congressos materiais de hipermídia para o desenvolvimento da leitura pianística.

\footnotetext{
${ }^{32}$ Devo todas as informações a Tuñez, M. Información. Mensagem recebida por beremusica@gmail.com em 20 mai. 2014.
} 
É autora de dois livros: De tecla en tecla: experiencias iniciales en la ejecución pianística, parceria com María José Zabala e objeto de estudo deste capítulo, e Como nos enganchamos, de 2009, coautoria com Carola Guglielmino.

Verbete biográfico: (informação pessoal) ${ }^{33}$ María José Zabala é pianista, educadora musical e professora de piano. Nasceu em Buenos Aires, na Argentina, em 1967. Iniciou seus estudos musicais aos 7 anos com María Rosa Oubiña de Castro. Posteriormente, estudou música de câmara com Virtú Maragno, música popular com Tato Finochi e educação musical com Violeta de Gainza. No conservatório Gilardo Gilardi de La Plata, obteve o título de professora superior de piano, e, desde 1991, dá aulas nessa mesma instituição. Entre 1987 e 2009, lecionou piano na Facultad de Bellas Artes e Bachillerato de Bellas Artes da Universidad Nacional de La Plata (UNLP).

Especialista em leitura, escrita e educação pela Facultad latinoamericana de Ciencias Sociales (FLACSO), há alguns anos, ministra oficinas e cursos de capacitação para docentes. Em paralelo, publica artigos e apresenta trabalhos em congressos diversos. Com Mirian Tuñez, escreveu De tecla en tecla: Experiencias iniciales en la ejecución pianística.

\section{De tecla en tecla: experiencias iniciales en la ejecución pianística}

De tecla en tecla foi publicado em Buenos Aires por El Farol Cooperativa de Trabajo Cultural, em 2007. Na introdução, as autoras explicam detalhadamente o conceito pedagógico das propostas, assim como o plano metodológico e a organização das atividades.

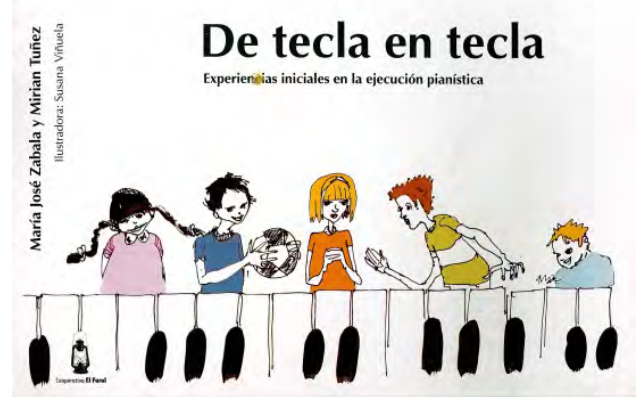

\footnotetext{
${ }^{33}$ Devo todas as informações a Zabala, M. J. Información. Mensagem recebida por beremusica@gmail.com em 20 mai. 2014.
} 
De acordo com Zabala e Tuñez (2007, p. 5), o livro foi idealizado para a iniciação ao piano de crianças a partir de 6 anos, estimulando a exploração, a experimentação e a percepção musical, iniciando-as na improvisação e na composição, consideradas pelas autoras imprescindíveis na formação do músico contemporâneo. A intenção primeira é que se conheça progressivamente o teclado, desenvolvendo a coordenação motora por meio de pequenas peças musicais e respectiva análise (informação pessoal). ${ }^{34}$

Alguns conceitos são citados como fundamentação teórica do projeto didático:

O conceito de "andaime" (Bruner); a definição da zona de desenvolvimento proximal (Vigotsky); o conceito de participação guiada e transferência gradual de controle de (Rogoff); a construção de estruturas e os processos de assimilação-acomodação (Piaget); os modos de conhecimento musical (Davidson e Scripp); o conceito de texto (Van Dijk) e o significado de uma didática grupal (Souto) (ZABALA; TUÑEZ, 2007, p. 6, tradução nossa).

A ideia principal do livro é integrar produção, percepção e reflexão, resultando na revisão do processo do aprendizado e numa nova experiência musical. A produção proposta não é só tonal e modal, apresentando diferentes estéticas aos alunos. De acordo com Zabala e Tuñez (2007, p. 7, tradução nossa), as atividades são agrupadas da seguinte maneira:

- Atividades de exploração livre: propõe-se um elemento - plástico, literário, musical ou motor - disparador da ação [...]. ${ }^{35}$

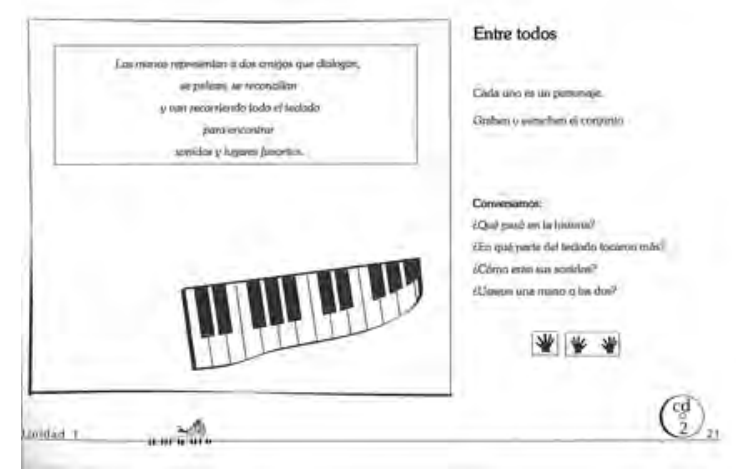

- Atividades de exploração programada: propõem esquemas unificadores células, motivos ou temas - para construir, ampliar e reelaborar, de acordo com o critério estético do aluno, os quais vão adquirindo sentido a partir da manipulação e transformação [...]. ${ }^{36}$

\footnotetext{
${ }^{34}$ Zabala, M.J.; Tuñez, M. Información. Mensagem recebida por beremusica@ gmail.com em 20 mai. 2014.

35 “Actividades de exploración libre: proponen un elemento disparador plástico, musical o motriz, a partir del cual se desarrolla la acción."

36 “Actividades de exploración pautada: proponen esquemas unificadores células,motivos, frases o temas para armar, ampliar y reelaborar, según critério estético del alumno, los que adquieren sentido con la manipulación y transformación [...]."
} 


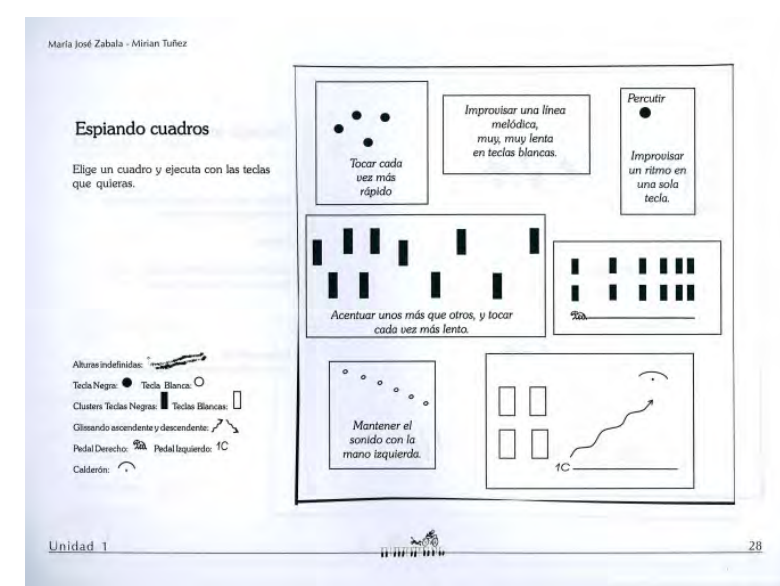

- Atividades de exploração combinada: apresentam-se textos de maior extensão, que unem leitura e improvisação, exercícios que dependem da prática, do reconhecimento de padrões e de ações dos procedimentos, da transferência e da retroalimentação dos conhecimentos adquiridos para o domínio instrumental. ${ }^{37}$

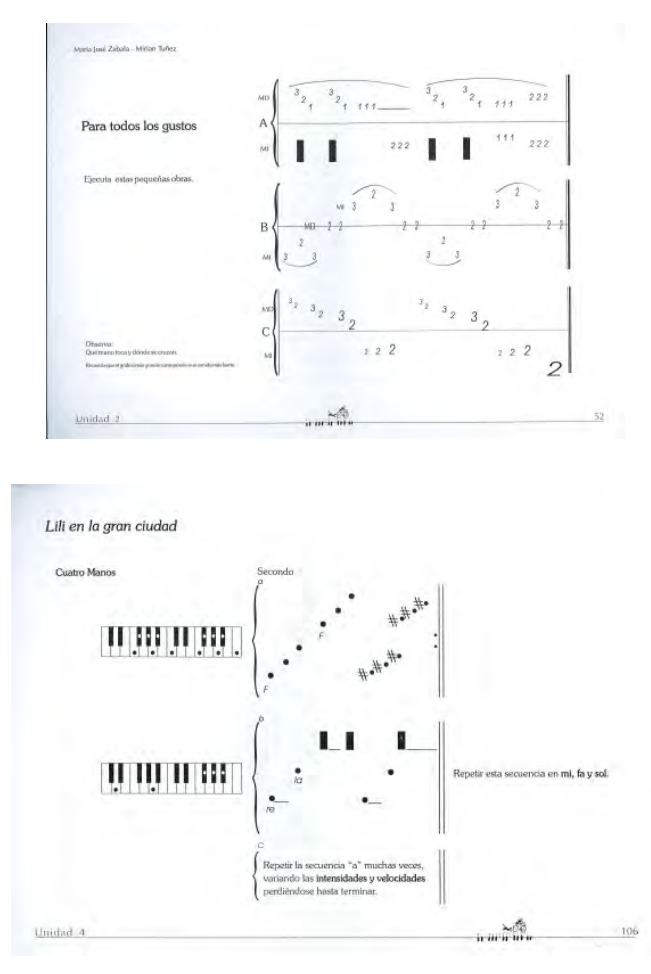

As autoras pretendem que o aluno vivencie essas atividades como uma experiência para apropriar-se dos recursos mais significativos e influenciar sua própria produção (ZABALA; TUÑEZ, 2007, p. 7).

\footnotetext{
37 “Actividades de exploración combinada: proponen textos de mayor extensión donde se conjugan instancias de lectura e improvisación que dependen más de la práctica, el reconocimiento de patrones, secuencias de acción de los procedimentos, la transferencia y la reetroalimentación de los conocimientos adquiridos en pos del dominio instrumental."
} 
De tecla en tecla foi organizado em quatro unidades, fundamentadas em dois eixos estruturais do livro: a topografia do teclado do piano e a coordenação, relativa a todas as ações de execução pianística ao sincronizar as duas mãos. As quatro unidades são:

unidade 1 - Atribuição de significado, intenção comunicativa

unidade 2 - Execução por digitação, individualização dos dedos

unidade 3 - Sincronização entre as duas mãos e familiarização com o nome das teclas unidade 4 - Integração e síntese de recursos

Os conteúdos que as autoras desenvolvem nas quatro unidades são:

A exploração e a manipulação do som e dos elementos da linguagem musical do piano. A descoberta das propriedades e das ações transformadoras dos materiais. $\mathrm{O}$ enriquecimento das possibilidades expressivas. A diferenciação e a sincronização motora. $\mathrm{O}$ reposicionamento do intérprete como autor. A valorização das decisões estéticas individuais. A prioridade a uma escuta aberta. A incorporação das contribuições tanto em grupo como individuais. A aceitação de diferentes níveis de compreensão e maturidade $^{38}$ (ZABALA; TUÑEZ, 2007, p. 8, tradução nossa).

A análise de De tecla en tecla revelou uma proposta de iniciação ao piano singular e bem fundamentada. As autoras deram ênfase ao processo criativo, passando da exploração inicial a diversas propostas que permitem ao aluno construir o conhecimento da linguagem musical a partir de suas próprias produções. A reflexão é valorizada em todo o processo, como uma ferramenta importante e integrada ao próprio fazer. Também é notável a preocupação de ampliar a referência estética musical dos alunos oferecendo possibilidades dentro e fora da tonalidade, assim como do tempo medido e não medido. Como as próprias autoras afirmam, o livro "recorre ao jogo como atividade de intercâmbio, integração e síntese de experiências significativas, outorgando um papel central às lógicas construtivas de cada aluno" 39 (informação pessoal). ${ }^{40}$ De fato, o livro se destaca por uma abordagem muito criativa, exigindo a participação reflexiva do aluno.

\footnotetext{
38 "La exploración y manipulación del sonido y los elementos del lenguaje musical en el piano. El descubrimiento de las propiedades y de las acciones de transformación de los materiales. El enriquecimiento de las posibilidades expressivas. La diferenciación y la sincrocización motriz. El reposicionamiento del intérprete como autor. La valorización de las decisiones estéticas individuales. La priorización de una escucha abierta. La capitalización de aportes tanto grupales como individuales. La aceptación de diferentes niveles de compreensión y maduración" (ZABALA; TUÑ̃EZ, 2007, p. 8).

39 "Recurre al juego como actividad de intercambio, integración y síntesis de experiencias significativas, otorgando un papel central a las lógicas constructivas propias de cada alumno."

${ }^{40}$ Zabala, M.J.; Tuñez, M. Información. Mensagem recebida por beremusica@ gmail.com em 20 mai. 2014.
} 


\title{
CAPÍTULO 2
}

\section{Criatividade}

\author{
Criar é, basicamente, formar. [...] Formar importa em \\ transformar [...]. Daí se nos apresenta outro aspecto que tanto \\ nos fascina no mistério da criação: ao fazer, isto é, ao seguir \\ certos rumos a fim de configurar uma matéria, o próprio \\ homem com isso se configura.
}

Fayga Ostrower

Com o objetivo de reafirmar a necessidade de desenvolver propostas que estimulem a criatividade musical dos alunos de piano, apresento as ideias de Hans-Joachim Koellreutter e de Violeta Hemsy de Gainza, elaborando um diálogo entre eles. Relacionadas ao pensamento desses dois educadores, outras abordagens também norteiam essa dissertação, como as das educadoras musicais Maria Teresa Alencar de Brito e Viviane Beineke, da pianista e compositora Moema Craveiro Campos e das educadoras Pamela Burnard, Anna Craft e Teresa Cremin, que discorrem sobre aprendizagem criativa.

A reflexão sobre a necessidade de expandir ou até mesmo abrir o espaço da criação nas aulas de piano advém da observação de diversos ambientes de educação musical e da análise informal de materiais publicados para o ensino de piano, ao longo de décadas de atuação profissional. Apesar da feliz constatação de uma crescente tendência à incorporação de processos mais criativos na educação musical, inclusive com métodos e livros como os analisados no primeiro capítulo, é fato que o ensino tradicional - focado apenas na leitura, na técnica e na aquisição de repertório - ainda orienta muitos professores particulares e instituições musicais do país, como afirma Moema Craveiro Campos:

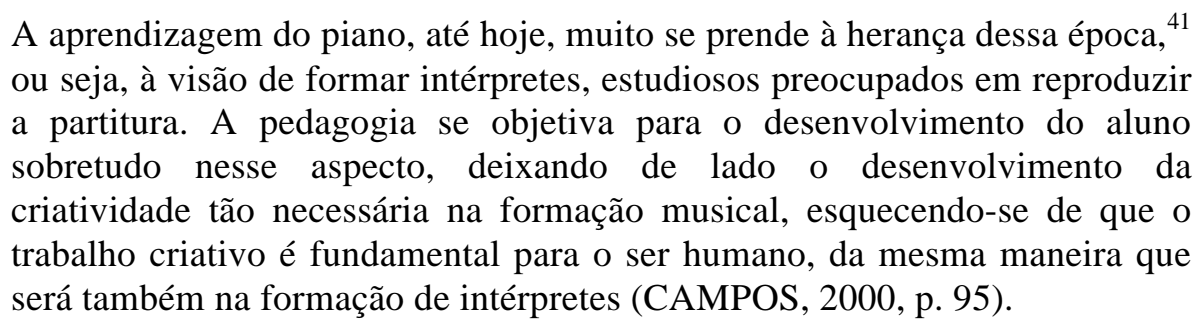

Ao estender a concepção vigente no ensino instrumental para a educação em geral, observamos consonância do pensamento de Campos com as afirmações da educadora Maria Candida Moraes (1997, p. 50):

\footnotetext{
${ }^{41}$ A autora se refere à cisão entre intérprete e compositor do final do século XIX.
} 
Reduzidas em sua criatividade e em suas possibilidades de expressão, as crianças encontram-se também limitadas em sua sociabilidade, presas a sua mente racional, impossibilitadas de experimentar novos voos e de conquistar novos espaços. Quando as crianças necessitam de folhas em branco para a expressão de sua criatividade, oferecemos espaços quadriculados e questões de múltipla escolha. Em vez de processos interativos para a construção do conhecimento, continuamos exigindo delas memorização, repetição e cópia, ênfase no conteúdo, resultado ou produto, recompensando seu conformismo, sua "boa conduta", punindo "erros" e suas tentativas de liberdade de expressão. Em vez de convergentes e inseparáveis, educação e liberdade constituem palavras antagônicas e excludentes.

Para elucidar o contexto educacional em que o ensino musical está inserido, considero relevante me deter um pouco mais, mesmo que sinteticamente, sobre uma questão que abarca a educação num sentido mais amplo. As décadas finais do século XX foram marcadas por transformações sociais, políticas e econômicas e descobertas significativas na ciência, na tecnologia e, como não poderia ser diferente, também na educação. As novas tecnologias da informação operaram e ainda operam mudanças no cotidiano, nas relações pessoais e profissionais e na própria forma de pensar das pessoas, principalmente a das novas gerações. Além de inovações e mudanças, o final do século XX e o início do século XXI trouxeram também questionamentos e quebra de paradigmas. ${ }^{42}$ De acordo com Moacir Gadotti, diretor do Instituto Paulo Freire, estamos vivendo um momento de expectativas e crise e que precisamos nos questionar sobre o que esperamos da educação no terceiro milênio e fazer "um balanço sobre práticas e teorias que atravessaram os tempos" (GADOTTI, 2006).

Neste trabalho, dentre diversos educadores, sociólogos e filósofos que questionam o momento atual e a educação, destaco algumas ideias de Edgar Morin (1921-), renomado antropólogo, sociólogo e filósofo francês da atualidade, que concebeu a teoria do pensamento complexo. Morin reconhece a importância do pensamento disjuntivo de Descartes (15961650) para o Ocidente, dos progressos científicos às reflexões filosóficas, mas afirma que a humanidade do século XXI precisa urgentemente superar o "grande paradigma do Ocidente" que, desde o século XVII, permanece na história europeia. ${ }^{43}$

\footnotetext{
${ }^{42}$ Segundo o filósofo Edgar Morin, paradigma pode ser definido como "um conjunto de regras, noções, padrões, teorias, modelos, visões de mundo que nos é legado inconscientemente" (MORIN, [s.d.]).

${ }^{43} \mathrm{Na}$ filosofia, Gilles Deleuze e Félix Guattari propõem um novo modo de pensar, radicalmente diferente do conceito de paradigma. Ao reconhecer que o pensamento cartesiano norteia o Ocidente há séculos, defendem uma mudança, construindo conceitos de outra ordem, como o de rizoma. Segundo Gallo (2003, p. 93), “[...] diferente da árvore, a imagem do rizoma não se presta nem a uma hierarquização nem a ser tomada como paradigma, pois nunca há um rizoma, mas rizomas; na mesma medida em que o paradigma, fechado, paralisa o pensamento, o rizoma, sempre aberto, faz proliferar pensamentos”. Cf. Deleuze e Guattari (1995).
} 
O paradigma cartesiano separa o sujeito e o objeto, cada qual na esfera própria: a filosofia e a pesquisa reflexiva de um lado; a ciência e a pesquisa objetiva de outro. Essa dissociação atravessa o universo de um extremo a outro: sujeito/objeto, alma/corpo, espírito/matéria, qualidade/quantidade, sentimento/razão, liberdade/determinismo, existência/essência (MORIN, 2011, p. 25).

$\mathrm{O}$ autor ressalta que a educação ainda é regida por esse pensamento dissociador e critica a forma como o conhecimento é ensinado:

[...] a supremacia do conhecimento fragmentado de acordo com as disciplinas impede frequentemente que se opere o vínculo entre as partes e a totalidade e deve ser substituída por um modo de conhecimento capaz de apreender os objetos em seu contexto, sua complexidade, seu conjunto (MORIN, 2011, p. 16).

Essa dissociação de saberes também pode ser observada no ensino tradicional de música: teoria se contrapõe a prática, técnica a expressão, intérprete a compositor, música erudita a música popular etc., e não se experencia o fazer musical em sua totalidade, dissociando a criação, a interpretação e a compreensão intelectual dos conceitos.

Para superar esse pensamento dissociativo, temos que reaprender a pensar, a interligar conhecimentos. Segundo Morin (2011, p. 42), "não se trata de abandonar o conhecimento das partes pelo conhecimento das totalidades, nem da análise pela síntese; é preciso conjugá-las”.

As ideias de Morin têm conexão com a primeira das referências teóricas deste trabalho: o pensamento de Hans-Joachim Koellreutter. Embora eles tenham trilhado caminhos diversos, há pontos de convergência entre suas teorias que são importantes para a reflexão aqui proposta. Dessa forma, apresento a seguir os princípios que nortearam a atuação de Koellreutter nos contextos cultural e educacional brasileiros.

\section{Hans-Joachim Koellreutter}

Hans-Joachim Koellreutter nasceu na cidade de Frieburg, na Alemanha, em 1915; naturalizou-se brasileiro e faleceu em São Paulo, em 2005. Koellreutter criou o movimento brasileiro Música Viva, foi compositor, flautista, doutor honoris causa das Universidades Federais da Bahia e do Ceará, pensador, ensaísta e educador; nas palavras do compositor e musicólogo Carlos Kater (1997, p. 7, grifos do original): “'músico criador', orquestrador e regente de um dinâmico ambiente para a música e a educação de nossa época". Para ele, 
Koellreutter era um educador no sentido mais amplo do termo. Não esteve à frente de uma sala de aula com crianças, mas atuou com músicos e professores de música buscando desenvolver uma educação conectada com os princípios vanguardistas da época, atual até hoje (KATER, 1997, p. 6-7).

O pensamento musical e pedagógico koellreutteriano foi construído a partir de estudos em diversas áreas além da música, conforme afirma Maria Teresa Alencar de Brito (2007, p. 21), que foi aluna e amiga do mestre:

A fenomenologia, ${ }^{44}$ especialmente sob o ponto de vista do filósofo francês Maurice Merleau-Ponty (1908-1961), a teoria da gestalt ${ }^{45}$ e as descobertas da física moderna (a teoria da relatividade e a física quântica) ao lado do estudo das culturas orientais embasaram seus estudos e reflexões, influenciando a produção de suas composições e a condução de seu trabalho como educador.

O próprio Koellreutter dizia: "sou um homem que se interessa não só pela música mas pela interdependência de todas as áreas” (TOURINHO, 1999, p. 221). O convívio com Hermann Scherchen (1891-1966) - importante regente alemão, divulgador e promotor da Neue Musik - influenciou imensamente sua formação pessoal e profissional: "[...] ele abriu realmente tudo, ensinou a evitar preconceitos, abrir a todas tendências. Foi talvez o mais importante que aprendi com ele. E também trato disso até hoje como princípio principal" (KOELLREUTTER apud ADRIANO; VOROBOW, 1999). Marcado profundamente pelas ideias de seu mestre e pelo estudo em diversas áreas do conhecimento, Koellreutter construiu um pensamento que norteou toda sua atuação, fosse como compositor, ensaísta ou educador.

Segundo Brito, "definir consciência foi, para ele, um exercício essencial no sentido de apreender e comunicar o paradigma do novo mundo anunciado" (2004, p. 67-68). Para Koellreutter $^{46}$ (1997h, p. 72), consciência era "a capacidade do homem de apreender os sistemas de relações que atuam sobre ele, que o influenciam e o determinam: as relações entre

\footnotetext{
${ }^{44}$ A palavra fenomenologia se origina de duas palavras gregas: phainesthai (fenômeno) - aquilo que se mostra, que aparece a nós primeiramente pelos sentidos - e logos - estudo, capacidade de refletir. A fenomenologia é um método de investigação filosófica fundado pelo filósofo e matemático Edmund Husserl (1859-1938). A partir de procedimentos rigorosos, pretende refletir sobre o fenômeno que se mostra para nós, na relação que estabelecemos com os outros, no mundo.

${ }^{45}$ A palavra gestalt é de origem alemã e não tem uma tradução literal para o português: significa dar forma, configurar. A Psicologia da Gestalt ou Psicologia da Boa Forma surgiu no final do século XIX, quando pesquisadores alemães empreenderam diversas pesquisas sobre a percepção humana, principalmente a visão. Os principais representantes que desenvolveram as leis da Teoria da Gestalt foram Max Werteimer (1880-1943), Kurt Koffka (1886-1941), Kurt Lewin (1890-1947) e Wolfgang Köhler (1887-1967). A teoria ampliou-se e transformou-se numa linha filosófica.

${ }^{46}$ É importante frisar que Koellreutter escreveu esses artigos por volta da década de 1950.
} 
um dado objeto ou processo e o homem, o meio ambiente e o eu que o apreende". Ainda: "a maneira como o ser humano vive, experimenta, imagina, vê o mundo depende da estrutura e do nível de sua consciência" (KOELLREUTTER, 1990, p. 1). Dessa forma, a relação do homem com a música, assim como com qualquer outra forma de representação humana, também dependeria do seu nível de consciência.

Às artes em geral e especialmente à música, ele as considerava "uma contribuição para o alargamento da consciência do novo ou do desconhecido e para a modificação do homem e da sociedade" (KOELLREUTTER apud ADRIANO; VOROBOW, 1999).

Algumas décadas antes de Morin, Koellreutter apontava a necessidade de transformarmos nosso modo de pensar, ainda enraizado nos preceitos dualistas e antagônicos do século XVIII (KOELLREUTTER, 1997i, p. 103). Ele concebia o século XX como uma época de mutação da consciência humana, que se encaminhava para uma nova era que exigia "uma consciência universalista através de um humanismo integrante [...] [que deveria superar] o contraste de 'crer' e 'saber', de 'fé' e 'ciência", (KOELLREUTTER, 1997b, p. 31), pois só através de ambos é que se pode se chegar à compreensão da totalidade do ser. A superação do homem fragmentado do século XX por um ser humano integral era uma das principais ideias propagadas por Koellreutter (1997g, p. 65), visando a formação de "um homem de tipo novo, pronto a contribuir para a transformação cultural que se processa dinamicamente em nosso tempo. Um homem que, internamente livre e aberto, seja capaz de viver com os conflitos desencadeados por essa transformação cultural".

Princípios da teoria do pensamento complexo, postulada por Morin (2011), já se encontravam nas ideias koellreutterianas, na década de 1950:

Todos os esforços, no entanto, serão vãos para a real compreensão das coisas da arte, tornando-se, na prática, mera rotina, quando não relacionarmos tanto os alunos, quanto os professores - os nossos conhecimentos com o todo. Com o todo da arte, com o todo de nossa existência, com o todo do meio ambiente e com o todo da sociedade em que atuamos. Pois é esse todo que nos estimula, que, como germe, vive em nós desde o princípio; o todo que é a vida espiritual, o espírito criador, propriamente dito. [...] Por isso, alunos desta Escola, apelo a vocês: deixem-se levar pela consciência das relações entre as coisas - é que a ciência moderna comprovou que não há objetos ou fatos, mas sim, exclusivamente, relações -, deixem-se levar pela consciência dessas relações, pela verdade de que nenhuma atividade intelectual pode ser isolada (KOELLREUTTER, 1997f, p. 54). 
Desde que chegou ao Brasil, Koellreutter dedicou-se à educação musical ao lado de sua atuação artística como flautista, pela qual fora reconhecido na Europa. No entanto, deixou de apresentar-se como instrumentista por considerar que o Brasil como se configurava na época não precisava desse tipo de profissional, mas de uma grande atenção às questões culturais e da educação. Continuou compondo e começou a trabalhar com educação musical no Rio de Janeiro e em São Paulo e, depois da década de 1950, também na Bahia, em Minas Gerais e no exterior, no Japão, na Índia e em alguns países da Europa.

Koellreutter tinha um pensamento amplo em relação à educação musical, conectado com sua concepção de mundo e coerente com sua atuação como músico e compositor, pois não considerava só a educação em sala de aula, a relação professor-aluno, mas pensava numa formação mais ampla, com concertos para formação de público, seminários, palestras etc.

A partir de algumas frases recorrentes em falas e textos de Koellreutter, revelam-se seus princípios pedagógicos:

[...] aprendo com o aluno o que ensinar. Há três preceitos: 1) não há valores absolutos, só relativos; 2) não há coisa errada em arte, o importante é inventar o novo; 3 ) não acredite em nada que o professor diz, em nada que você ler e em nada que você pensar; pergunte sempre "por quê?" (KOELLREUTTER apud ADRIANO; VOROBOW, 1999).

[...] as perguntas têm mais importância do que as respostas (KOELLREUTTER, 1997f, p. 53).

[...] tudo o que choca, conscientiza [...] o choque é sempre um meio de consientização e do ponto de vista pedagógico isso é muito importante (BRITO, 2004, p. 122).

[...] o alicerce do ensino artístico é o ambiente [...] O princípio vital, a alma desse ambiente, é o espírito criador (KOELLREUTTER, 1997f, p. 53).

Aliada a essa postura instigadora, Koellreutter tinha o alargamento da consciência, o espírito de pesquisa e a criação como princípios e metas da arte e da educação. Para ele, o ensino tradicional de música estava totalmente ultrapassado e ligado aos paradigmas do século XIX, por isso, fazia-se imprescindível transformá-lo em conformidade ao século XX:

É verdade que o espírito criador deve ter suas raízes na tradição, nos tempos passados, em mundos estranhos portanto, mas jamais ele deve isolar-se e afastar-se do presente real. Assim ele despertará forças para elucidar o presente e para contribuir resolutamente para a construção do futuro da humanidade (KOELLREUTTER, 1997f, p. 57). 
Koellreutter concebeu uma proposta de ensino pré-figurativo, cuja meta principal era o ser humano:

Trata-se de um tipo de educação musical que aceita, como função da educação musical nas escolas, a tarefa de transformar critérios e ideias artísticas em uma nova realidade, resultante de mudanças sociais [...] O humano, meus amigos, como objetivo da educação musical (KOELLREUTTER, 1998, p. 44).

A proposta propunha a transformação da postura do professor e do próprio aluno. Koellreutter buscou um "sistema educacional em que não se 'educa', no sentido tradicional, mas sim em que se conscientiza e 'orienta' os alunos através do diálogo e do debate" (KOELLREUTTER, 1997g, p. 65). O tradicional dualismo professor-aluno, no qual o primeiro ensina e o segundo aprende, seria substituído por uma relação em que o diálogo imperaria e o "professor faria música com o aluno, onde eles se autoeducariam por meio do debate, do diálogo" (KOELLREUTTER apud BRITO, 2004, p. 121).

No ensino pré-figurativo, o aluno é instigado a se conscientizar das relações entre as coisas do mundo. Para Koellreutter, "o traço fundamental da experiência artística é a compreensão, a compreensão do todo, da dialética das relações de tudo com tudo. Só se integrando na problemática de nossa existência e vivendo na interdependência das coisas, esplende o espírito criador" (KOELLREUTTER, 1997f, p. 56).

Com base nesses princípios norteadores, Koellreutter elegeu a improvisação como ferramenta fundamental na educação musical, acreditando que através da improvisação era possível integrar a prática e a teoria, isto é, conscientizar os conceitos a partir do próprio fazer musical. No entanto, ele fazia questão de afirmar que usar a improvisação na educação musical não é, simplesmente, "fazer qualquer coisa [...] não há nada que precise ser mais planejado do que uma improvisação” (KOELLREUTTER apud BRITO, 2004, p. 130).

Depois de voltar da Índia, na década de 1970, Koellreutter se dedicou a desenvolver um projeto de educação musical voltado para todos, não só para músicos, e que tinha como proposta tanto a formação musical como a humana. Nessa proposta, criou vários modelos de improvisação musical (BRITO, 2001; KATER, 1997). Segundo Brito (2001, p. 93), Koellreutter considerava que a comparação era a melhor forma para nos conscientizar de alguma coisa, e os modelos de improvisação eram ótimos meios para esse fim. Ainda segundo 
a autora, esses modelos promovem o desenvolvimento e o conhecimento de aspectos musicais - como por exemplo métrico, amétrico, densidades etc. -, e também humanos - como concentração, autodisciplina, capacidade de dialogar e interagir entre outros. Em cada um deles, há algumas indicações, como temática ou faixa etária, e critérios para críticas e avaliação, pois ele considerava muito importante o debate e a reflexão para a construção do conhecimento.

Koellreutter se voltou para questões do século XXI ainda no século XX. Era aberto ao novo, ao futuro, como ele mesmo disse: “[...] O passado é um meio e um recurso, de maneira nenhuma um dever. O futuro, porém, é” (KOELLREUTTER, 1997d, p. 42). Esse olhar para o futuro conduziu também sua concepção como educador e, talvez por isso, é possível identificar, em seu corpo de ideias, conexões e convergências com um pensamento contemporâneo de educação. $\mathrm{O}$ ensino pré-figurativo concebido por ele fundamenta-se em preceitos que anteviam o pensamento educacional do século XXI, como o diálogo, o conhecimento construído coletivamente, o respeito pelo outro, a relação entre os conceitos e as diferentes áreas do conhecimento humano e até a formação continuada de professores. Esses mesmos princípios, defendidos por Koellreutter décadas atrás, estão nas orientações do Relatório para a UNESCO da Comissão Internacional sobre Educação para o século XXI, que aponta a direção educacional a ser tomada frente aos desafios do novo século, a partir de quatro pilares fundamentais: aprender a conhecer, aprender a fazer, aprender a viver juntos e aprender a ser, aliados ao estímulo, às descobertas e ao fortalecimento do potencial criativo das pessoas (DELORS, 1999, p. 90).

Hans-Joachim Koellreutter antecipou conceitos e posturas, apontando como necessidade premente a busca por transformações e elegendo a criação como fundamento de qualquer fazer artístico: "sem o espírito criador não há arte, não há educação. É essa uma verdade que os educadores tão facilmente esquecem" (KOELLREUTTER, 1997f, p. 53). Nas palavras de Brito:

Com liberdade, ousadia, disciplina, capacidade de análise, criatividade e espírito crítico, Koellreutter integra o espírito racionalista ocidental alemão às experiências vivenciais no Oriente. E, assim, escuta, compõe, analisa, ensina, educa, cria e recria conceitos, num exercício que, no entanto, não se funda nas regras e estruturas do academicismo, mas, sim, na vivência e na experiência estética (BRITO, 2004, p. 140). 


\section{Violeta Hemsy de Gainza}

Apresento aqui algumas ideias de Violeta Hemsy de Gainza. Figura de destaque no cenário da educação musical, Gainza nasceu na cidade de Tucumán, na Argentina, em 1930. Licenciou-se em Música, na Escola de Música da Universidade de Tucumán, e em Química, pela mesma Universidade. Hoje, ministra conferências e palestras em congressos e eventos por toda a América Latina e em países da Europa, escreve artigos e livros e leciona piano. Está sempre conectada às transformações e tendências da área, como ela mesma aponta:

Durante quase toda minha vida profissional, mantive uma atitude permanente de observação e questionamento das grandes linhas, tendências e orientações dentro da profissão, trabalhando aqui, em meu país, voltada para cá, mas com um olhar para fora, adiante ${ }^{47}$ (GAINZA, 2007, p. 18, tradução nossa).

Sua vasta experiência pedagógica começou quando ainda era adolescente, aos 13 anos, quando começou a dar aulas de piano para crianças de sua idade ou mais novas que precisavam se preparar para exames (GAINZA, 2007, p. 117). Anos depois, ao retornar à Argentina depois de sua especialização em pedagogia musical pela Universidade de Columbia, nos Estados Unidos, não parou mais de lecionar e pensar sobre educação musical, construindo um sólido pensamento pedagógico-musical. Em seus mais de quarenta títulos publicados, há reflexões profundas sobre inúmeros aspectos da relação da música com o homem, na esfera individual e social, e sobre as práticas da pedagogia musical, tendo a criação e a prática reflexiva como eixos norteadores.

Da observação atenta da criatividade espontânea de seus sobrinhos, para quem deu aula no início de sua atuação profissional (GAINZA, 2007, p. 120), até suas publicações mais atuais (GAINZA, 2013), a autora construiu um aporte de ideias que concebe a música como experiência multidimensional, por se manifestar em diversas instâncias sequenciais ou simultâneas, abarcando "[...] o pessoal e o social, o cotidiano e o transcendente, o natural e o cósmico, a saúde e a doença, o ético e o estético, entre outras categorias"48 (GAINZA, 2002, p. 140, tradução nossa). Segundo Gainza, a multiplicidade do processo relacional entre música e homem acontece em algumas instâncias:

\footnotetext{
47 "Durante casi toda mí vida profesional mantuve una actitud permanente de observación y cuestionamiento de las grandes líneas, tendencias y orientacines dentro de la profesión, trabajando aquí, en mí país, desde adentro, pero con la mirada puesta afuera, más allá” (GAINZA, 2007, p. 18).

48 “[...] lo personal y lo social, lo cotidiano y lo transcendental, lo natural y lo cósmico, la salud y la enfermedad, lo ético y lo estético, entre otras categorías" (GAINZA, 2002, p. 140).
} 
Em uma primeira instância, a música seria captada como energia $[\ldots]$ ou como alimento, para dimensionar-se depois como linguagem de comunicação e como objeto cultural e artístico. Precisamente, essa pluralidade de funções explica e justifica, entre outros aspectos, o poder educativo e terapêutico da música ${ }^{49}$ (GAINZA, 2002, p. 140, tradução nossa, grifos do original).

Gainza considera que a música é energia que nos perpassa e reflete em nós, produzindo efeitos e reações diversas, deixando-nos estimulados, contidos, inflamados, calmos, entre muitos outros estados de ânimo, mobilizando aspectos afetivos, físicos e mentais da pessoa. Mas a música também é alimento, pois parte do que absorvermos sonora e musicalmente se integra a nós, nos impregna, nos harmoniza. Essa instância é central no processo de educação musical, pois a absorção da música como alimento determina a forma como se desenvolve e estrutura o mundo sonoro de cada um. A partir dessas duas instâncias, muitas outras foram se ampliando na relação homem-música, como música linguagem, arte e mito. A música é linguagem quando há hierarquização entre o conteúdo e a forma, e, dependendo da qualidade e da transcendência da linguagem, ela pode se transformar em arte (Gainza afirma que a arte só pode surgir a partir da existência prévia da linguagem). Por último, aponta a construção do mito da música, quando há confusão e mesmo sobreposição entre a própria matéria e o símbolo que a representa, ou quando se confunde a realidade com a evocação da música. É comum compositores e obras serem culturalmente divinizados, propagando a ideia de que a música é algo inatingível. Diante disso, a autora adverte sobre a dificuldade de muitos estudantes frente ao mito de uma música tão suprema, que eles nunca conseguirão produzir (GAINZA, 2013, p. 64-66).

A partir dessas cinco instâncias ou funções, Gainza explica a ampla dimensão das ações musicais na área terapêutica, social e educacional. No campo educacional, especialmente, a autora aponta a importância da confluência de diversos processos:

Um processo educativo-musical implica, portanto, uma multiplicidade de processos de apropriação, expressão e aprendizagem a partir da prática e da vivência musical, integrando, por uma parte, a absorção de novos materiais e experiências, e, por outra, o desenvolvimento das potencialidades musicais de forma abrangente, inatas ou adquiridas, do educando. $\mathrm{O}$ educador musical, ao assumir a condução dos processos de desenvolvimento musical, equilibrará a intensidade, a profundidade e o direcionamento dos mesmos, de

\footnotetext{
49 "En una primera instancia, la música sería captada como energía [...] ou como alimento, para dimensionarse luego como lenguaje de comunicación y como objeto cultural y artístico" (GAINZA, 2002, p. 140).
} 
acordo ao que seja necessário aos diferentes níveis de ensino ${ }^{50}$ (GAINZA, 2002, p. 141, tradução nossa).

Assim como Koellreutter, Gainza vislumbra um futuro promissor para a humanidade, no qual teremos uma comunicação muito mais inteligente, eficiente e que integrará uma multiplicidade de meios e formas diversas da experiência, da tecnologia e da filosofia humana, apesar das grandes dificuldades enfrentadas pela humanidade no final do século passado e início deste milênio. A autora acredita nesse futuro e considera que o grande desafio dos educadores frente a essa realidade é o de orientar, guiar sua ação pedagógica a partir das necessidades mais profundas do aluno (GAINZA, 2002, p. 28). A máxima koellreutteriana "apreender do aluno o que ensinar" sintoniza-se perfeitamente com o pensamento da educadora argentina, que defende modelos pedagógicos abertos mais conectados às necessidades do século XXI. Por pedagogia aberta, a autora entende:

A abertura pedagógica remete aos aspectos filosóficos da educação, mas também às técnicas educativas. Implica na avaliação da situação atual para, então, programar intervenções que promovam o desenvolvimento ao longo dos diferentes ciclos da educação formal. A partir de uma ação de caráter global e aberta sobre a realidade, em qualquer momento será possível limitar o objetivo, "estreitá-lo" funcionalmente, para alcançar um objetivo concreto [...] Assim como os modelos condutistas apontam para a produção em série, as pedagogias abertas tendem a liberar o pensamento e a expressão $[\ldots]^{51}$ (GAINZA, 2002, p. 29, tradução nossa).

Faz-se evidente, nos diversos textos de Gainza, seu conhecimento sobre os métodos e tendências pedagógico-musicais que construíram a história da educação musical ao longo do século XX. Gainza (2002, p. 67, tradução nossa, grifos do original) divide essa história em três grandes épocas:

- primeira metade do século XX: de "revolução e mudança”, refere-se aos métodos ativos, que trouxeram o "movimento" para a educação musical, sendo os aspectos

\footnotetext{
50 “Un proceso educativo-musical implica, por lo tanto, una multiplicidad de procesos de apropiación, expresión y aprendizaje, a partir de la práctica y la vivencia musical, integrando , por una parte, la absorción de nuevos materiales y experiencias, y por otra, el desarrollo de las potencialidades musicales e integrales, innatas y adquiridas, del educando. El educador musical, al hacerse cargo de los procesos de desarrollo musical, calibrará la intensidad, la profundidad y la direccionalidad de estos mismos, según lo requieran los diferentes níveles de la enseñanza” (GAINZA, 2002, p. 141).

51 "La apertura en lo pedagógico remite a los aspectos filosóficos de la educación pero también a las técnicas educativas. Implica la evaluación y el análises de la situación actual para, desde allí, programar intervenciones orientadas a promover procesos de desarrollo a lo largo de los diferentes ciclos de la educación formal. A partir de una acción de caráter global y abierto sobre la realidad, en cualquier momento será posible acotar el objetivo, "cerrarlo" funcionalmente, para el logro de un objetivo concreto. [...] Así como los modelos conductistas apuntan a la producción en serie, las pedagogías abiertas tienden a liberar el pensamiento y la expresión [...]" (GAINZA, 2002, p. 29).
} 
vitais e ativos do educando seu eixo principal, e têm como principais representantes Émile Jacques-Dalcroze (1869-1950), Edgar Willems (1890-1978), James Mursell (1893-1963), Maurice Martenot (1898-1980), Carl Orff (1895-1982), Zoltán Kodály (1882-1967), entre outros;

- 1960-1970: de "revisão e atualização", com foco nos processos de criatividade, tendo como representantes George Self (1921), Murray Schafer (1933-), Folke Rabe (1935-), Brian Dennis (1941-1998), entre outros;

- por volta da década de 1980: a da consciência, "tende a reforçar a integração $e$ autonomia dos processos criativos e conscientes da aprendizagem".

Mais tarde, Gainza (2013) subdivide essas três grandes épocas em seis períodos, detalhando seus enfoques, representantes e contribuições. No sexto período, que ela denomina "novos paradigmas", aponta a existência de muitos modelos pedagógicos ${ }^{52}$ e uma potencialidade criativa muito grande, mas adverte que se faz necessário que "os professores de música e arte se reúnam para se conhecer melhor, intercambiar inquietações e refletir sobre seus princípios comuns que os guiam e aprendam a discernir o supérfluo do profundo, o falso do verdadeiro, o urgente do fugaz e desnecessário" "53 (GAINZA, 2013, p. 60, tradução nossa).

Tanto em suas publicações como em palestras e cursos, Gainza destaca dois temas como fundamentais para a educação musical da atualidade: a reflexão sobre os processos de ensino e aprendizagem que levam à conscientização do vivido e a integração dos três principais enfoques das três grandes épocas: movimento, criatividade e consciência. Segundo suas ideias, vivemos um momento na educação musical que deve primar pela integração entre o fazer e o pensar: "a teoria sucede a prática, partindo da ação ao conceito e ao símbolo" 54 (GAINZA, 2002, p. 25, tradução nossa). Mais uma vez, observamos uma sintonia entre Gainza e as ideias koellreutterianas, nas quais tanto o espírito criador como a ideia de consciência são elementos fundamentais.

\footnotetext{
52 Gainza distingue método de modelo, definindo método como uma criação individual, em geral, em que materiais e atividades são apresentados de forma sequenciada e com ênfase de determinado aspecto musical; já modelo seria uma produção mais coletiva, com nomes que se destacam, mas não tomam para si a autoria, constituindo-se como um conjunto de materiais, atividades e condutas sem uma sequência exata e que podem se combinar com outros (GAINZA, 2013, p. 59-60).

53 “....] los docentes de música y de arte se acerquen entre sí, para conocerse mejor, intercambiar inquietudes y reflexionar acerca de los móviles comunes que los guían, y para aprender a discernir lo superfluo de lo profundo, lo falso de lo verdadero, lo urgente de lo fugaz e innecesario" (GAINZA, 2013, p. 60).

54 “[...] la teoría sucede a la prática y se procede desde la acción hacia el concepto y el símbolo" (GAINZA, 2002, p. 25).
} 
Nas propostas de Gainza, assim como nas de Koellreutter, o recurso da improvisação é valorizado, apresentando-se como estratégia para desenvolver a criatividade e como forma de apropriação dos elementos musicais:

A pedagogia contemporânea se ocupa tanto dos processos como das metas; a música, além de arte e ciência, é uma linguagem cujo domínio se adquire paulatinamente através de um desenvolvimento dialético no qual a improvisação é um recurso de grande transcendência e eficácia ${ }^{55}$ (GAINZA, 2002, p. 68, tradução nossa).

Para Gainza (2002, p. 56), a improvisação acessa estruturas musicais internalizadas da pessoa e constrói novas estruturas e materiais musicais, por isso revela-se como valiosa ferramenta no processo de desenvolvimento musical.

Analisando Método para piano, Palitos chineses e Nuestro amigo el piano (outra coletânea de composições de seus alunos), percebemos a importância que a educadora confere ao espaço da criação, seja em propostas de improvisação ou mesmo de composição de melodias, e sua ideia de que propostas criativas devem estar entre os aspectos desenvolvidos em uma aula de instrumento:

Improvisar em música é como falar na linguagem comum. Um estudante adiantado, que passa horas praticando peças e exercícios em seu instrumento, deveria pelo menos ser capaz de expressar ideias musicais de um nível de dificuldade equivalente às conversas simples que improvisa cotidianamente quando se encontra com um $\operatorname{amigo}^{56}$ (GAINZA, 2014a, tradução nossa).

Outro ponto comum entre as ideias de Gainza e as de Koellreutter é a crítica implícita ao ensino tradicional, que apoia o aprendizado instrumental só no estudo de repertório, em detrimento de propostas criativas que valorizem a expressão individual.

Já que a futura sensibilidade da criança é gerada no nível inicial, é fundamental que os professores compreendam que o prazer pela música implica e exige o jogo livre com a voz e com os instrumentos, muito mais do que a reprodução exata de modelos preestabelecidos, ponto de partida e,

\footnotetext{
55 “A la pedagogía contemporánea le interesan tanto los procesos como las metas; la música, además de arte e ciencia, es un lenguaje cuyo dominio se adquiere, paulatinamente, a través de un desarrollo cialéctico en que la improvisación constituye un recurso de gran transcendencia y eficacia” (GAINZA, 2002, p. 68).

56 “Improvisar en música es lo más proximo al hablar en lenguaje común. Un estudiante adelantado que pasa varias horas al día practicando piezas y ejercicios en su instrumento debería también, por lo menos, ser capaz de expresar ideas musicales de un nivel de dificultad equivalente a las conversaciones simples que improvisa cotidianamente cuando se encuentra de pronto con un amigo" (GAINZA, 2014a, s/p).
} 
muitas vezes, objetivo implícito do ensino tradicional ${ }^{57}$ (GAINZA, 2014b, tradução nossa).

A escola torna-se um agregado de cursos estanques, mais ou menos bem dados, onde o professor repete doutoral e fastidiosamente a lição já repetida nos anos anteriores, ou treina seus discípulos como se amestram animais de circo, pela repetição indefinida do mesmo ato, discípulos ansiosos para aprender a técnica de um instrumento [...] a fim de transmitir uma mensagem artística. Essa situação, apesar de ser uma realidade, essa concepção das coisas, apesar de ser muito difundida, extingue no aluno o que nele houver de criativo [...]. A mudança do conteúdo e dos programas de uma educação que tenda essencialmente ao questionamento crítico do sistema e à sua reprodução, que tenda ao despertar e ao desenvolvimento da criatividade e não à adaptação e à assimilação [...] (KOELLREUTTER, 1997f, p. 54-55).

Há também sintonia entre os dois autores em relação à importância da postura do professor para a efetivação de uma transformação no ensino musical. Para Gainza, é necessário formar docentes reflexivos e criativos, com preparação musical e pedagógica, mas inquietos e investigadores. Para Koellreutter, uma pedagogia conectada com as urgências e as necessidades de um novo milênio deve mudar, antes de tudo, a formação e consequente ação do professor. Nas palavras da educadora argentina:

Diante da necessidade permanente de interpretar o dogma pedagógico, precisamos de professores solidamente formados/informados, com capacidade para selecionar e decidir (assim como o médico diante do enfermo e o crente diante do dogma religioso). Ao mesmo tempo, para assegurar a personificação e a humanização da pedagogia musical, fazem falta professores flexíveis e criativos (sensíveis/inteligentes), formados na liberdade, e não um exército de clones adestrados para aplicar da maneira "certa" o dogma pedagógico ${ }^{58}$ (GAINZA, 2013, p. 147, tradução nossa).

E nas afirmações do compositor alemão:

O professor do nosso movimento é o conselheiro, o guia e, principalmente, o amigo do aluno. Consciente da relatividade de sua cultura, está sempre disposto a aprender e a enriquecer seus conhecimentos com os que confiam a ele sua formação. [...] A fadiga e a monotonia de exercícios conduzem à mecanização tanto dos professores quanto dos discípulos [...] é indispensável que em todo o ensino artístico se sinta o alento da criação (KOELLREUTTER, 1997b, p. 30-31).

\footnotetext{
57 "Ya que es en el nivel inicial donde se gesta la futura sensibilidad del niño, es fundamental que los maestros comprendan que el placer de la música implica y exige el juego libre con la voz y con los intrumentos, más allá de la reproducción exacta de modelos preestablecidos, punto de partida y a la vez objetivo implícito de la enseñanza tradicional" (GAINZA, 2014b, s/p).

58 "Ante la necesidad permanente de interpretar el dogma pedagógico, se requieren maestros sólidamente formados/informados, con capacidad para elegir y decidir (igual que el médico frente al enfermo, igual que el creyente frente al dogma religioso). Al mismo tiempo, para asegurar la personalización y humanización de la pedagogía musical, hacen falta maestros flexibles y cretivos (sensibles/inteligentes), formados en la libertad, y no un ejército de clones adiestrados para aplicar de 'cierta' manera el dogma pedagógico" (GAINZA, 2013, p. 147).
} 


\section{Escutando o fazer musical da infância - Teca Alencar de Brito}

Para complementar as referências teóricas expostas anteriormente e fundamentar ainda mais a proposição de incluir improvisações e possíveis composições das crianças no corpus das atividades de ensino e aprendizagem do piano, apresento o pensamento educacional de Maria Teresa Alencar de Brito, consonante com as ideias koellreutterianas e algumas das principais concepções de Gainza sobre educação musical e grande influência teórica no meu modo de pensar a música e o ensino de crianças e na minha própria atuação profissional.

Sobre a postura do professor e a relação professor-aluno, questão explicitada nos dizeres de Koellreutter e Gainza, Brito aponta uma possibilidade de construção do espaço professor-música-aluno, passando necessariamente por uma nova concepção do que é ser professor. Ela considera que "[...] o acontecimento musical deve se atualizar em ambientes de parceria entre alunos e professores, coautores e responsáveis pelas tramas sonoras emergentes que, dessa feita, assumem efetivo sentido e significado (BRITO, 2010, p. 92, grifos nossos).

Ao longo de várias décadas, Brito construiu seu fazer/pensar/educar musical em sala de aula com crianças, com uma postura investigativa e uma observação aguda do modo de ser das crianças, transformando suas próprias ideias de música (BRITO, 2009, p. 25).

Como citado anteriormente, a convivência com Koellreutter marcou profundamente sua trajetória:

Estudar e conviver durante muitos anos com o músico, compositor e educador alemão naturalizado brasileiro Hans-Joachim Koellreutter (19152005) foi essencial, já que, dentre outros importantes aspectos, ele estimulou a adoção de condutas de observação, de análise, de reflexão, pesquisa e especialmente - de respeito à singularidade, às diferenças. A escuta e o olhar do educador deveriam, segundo ele, focar a história de cada aluno, de cada grupo, de cada configuração... considerando uma série de possíveis. Focando particularidades envolvidas na questão da realização musical ele entendia que era preciso rever ideias e conceitos - contínua e dinamicamente -, com vias a evitar a padronização e o consequente empobrecimento do trabalho (BRITO, 2009, p. 26).

Nota-se a ressonância das ideias de Koellreutter em seu foco de pesquisa: a singularidade do fazer musical das crianças. A partir da concepção de que a relação entre música e sujeito acontece permeada pelo meio, em processos dinâmicos que constroem significados, Brito considera que "as crianças também são capturadas por ideias de música" 
que estão permeadas pela interação com os mais diversos sons do ambiente e pelo meio cultural em que estão imersas. Assim, cada criança se relaciona com o sonoro e com o musical de forma singular, mesmo que inseridas no “caldeirão' dos universais” (BRITO, 2007, p. 68-69).

Segundo a educadora, a relação com a música é uma das muitas formas do brincar infantil, criando canções, imitando os gestos de tocar um instrumento tendo ou não o objeto na mão. Embora o brincar musical da criança seja natural, a autora adverte que a sociedade e os próprios sistemas educacionais não o valorizam como se deveria (BRITO, 2007, p. 69).

Faz-se pertinente para a reflexão proposta nesta dissertação observar o pensamento de Brito sobre o fazer musical da infância e, consequentemente, sobre o espaço reservado nas instituições escolares para a criação autoral da criança. A autora alerta que, mesmo diante de novos discursos na educação, prevalecem concepções educacionais que priorizam a reprodução, considerando que só depois de anos de estudo o aluno terá condições de criar. Ela ressalta também que, quando se refere a criações musicais, não considera a concepção vigente de que só é composição a música criada dentro das regras de uma única forma de pensar e fazer música. Sobre essa concepção e a música na infância, Brito complementa:

Quando a ideia de música, em si mesma, é uma ideia que se atualiza apenas na complexidade de um sistema que quase se fecha em suas próprias regras, é preciso muito preparo e quase autorização para poder criar, algo que costuma levar muito tempo. Indiferentes a isso, entretanto, as crianças seguem improvisando e inventando, lidando com o musical em sintonia com sua consciência e criando linhas de fugas que marcam sua presença e inserção no mundo (BRITO, 2007, p. 69-70).

A partir de um estudo aprofundado de ideias, invenções e realizações musicais de crianças, Brito advoga a favor de um espaço de educação musical que propicie às crianças "fazer escutas, inventar, pensar e enveredar por muitos e inusitados lugares" (2009, p. 33).

Essas reflexões sobre o fazer musical das crianças e a postura pertinente do educador constituem o corpo do que Brito denomina Educação Musical do Pensamento. A partir da experiência com as crianças, do contato com as ideias de Koellreutter, com conceitos da filosofia de Gilles Deleuze (1925-1995) e Félix Guattari (1930-1992), com a teoria dinamicista da psicóloga e cientista cognitivista Esther Thelen (1941-2004) e com o diálogo com "Maturana e Varela, Merleau-Ponty, Delalande, Piaget, Paulo Freire, Muniz Sodré, Fonterrada... para lembrar alguns" (BRITO, 2009, p. 26), a educadora discorre amplamente 
sobre essa educação musical em modo menor em sua tese de doutorado (BRITO, 2007) e, mais resumidamente, em seu artigo "Por uma educação musical do pensamento: educação musical menor" (BRITO, 2009).

Os termos modo menor e modo maior ganharam significados distintos daqueles da terminologia musical. Gilles Deleuze e Félix Guattari criaram o conceito de literatura menor para analisar a obra de Franz Kafka, que, segundo eles, era uma obra revolucionária pois apresentava uma insubordinação por meio da própria língua alemã. Segundo o filósofo Silvio Gallo, esse conceito indica uma literatura que usa a própria língua como meio de desagregação, resistindo ao controle e provocando novos agenciamentos. Gallo sugere, então, um deslocamento para a educação, apresentando a ideia de educação menor, que se comprometeria com a transformação do estabelecido, investindo "num processo educativo comprometido com a singularização, comprometido com valores libertários" (GALLO, 2003, p.75), e educação maior, que estaria estabelecida e determinada a "instituir-se, fazer-se presente, fazer-se acontecer" (GALLO, 2003, p. 78). Brito (2007, p. 7) complementa a explanação de Gallo, elucidando que a educação maior está relacionada às diretrizes educacionais oficiais, que lidam com a educação em grande escala, com a sistematização da educação, com padrões organizados antecipadamente, e a educação menor é "sempre um ato de resistência, presente na militância da sala de aula, no empenho com os atos cotidianos".

A educadora operou um segundo deslocamento e transpôs conceitos da filosofia e da educação para o âmbito da educação musical, criando o conceito de modo menor e modo maior. A autora aplica a ideia de modo menor em dois sentidos:

[...] por um lado, como resistência, atuando com outro modo de estabelecer relações e fazer música nos territórios da educação musical, resistindo aos padrões preestabelecidos que enfatizam o produto, ao invés do processo; por outro lado, apontando a singularidade das ideias de música das crianças, que são "modos menores" frente aos modelos tradicionais (BRITO, 2014, informação verbal). ${ }^{59}$

Como modos maiores de educar, Brito (2007, p. 7) indica os métodos e sistemas de educação musical que visam a mera aquisição de competências que habilitem o aluno a um fazer musical dentro dos padrões tradicionais e que não consideram a possibilidade de trocas que extrapolam o conhecimento musical em questão. Ainda no sentido de clarificar os conceitos, Brito amplia a definição de modo menor a partir da oposição entre eles:

\footnotetext{
${ }^{59}$ Informação fornecida por Brito em São Paulo, em 2014.
} 
Modo que instaura uma educação musical do pensamento, em oposição àquela que visa à inteligência: limitada à transmissão de conceitos e informações; preocupada em treinar o desenvolvimento de competências técnicas; ensinando a repetir o igual; padronizando, desconfigurando, guiando-se pelo tempo relógio que comanda e determina percursos e atividades (BRITO, 2007, p. 259).

Dessa forma, para educar em modo menor, musicalmente ou não, faz-se necessário mudar a postura do educador, para que se propiciem ambientes que abarquem essa outra maneira de se relacionar com as crianças e com o próprio conhecimento. O modo menor “implica resgatar valores, modos de ser e de conviver, de ensinar e de aprender, de transformar, de criar..., resistindo ao controle, à padronização e ao consequente empobrecimento que, infelizmente, atestamos quase que cotidianamente nos planos maiores do educar" (BRITO, 2007, p. 258).

A ideia de uma educação em modo menor encontra inúmeros pontos de conexão com o pensamento koellreutteriano. Na dissertação de mestrado da própria autora, encontram-se várias delas, como a seguinte:

Quando trata da questão da educação musical, Koellreutter propõe que os
processos de aquisição de competências musicais de cada indivíduo - para
escutar, produzir, refletir - sejam entendidos e tratados como processos de
conscientização e não como mera aprendizagem no sentido tradicional da
instrução. Para tanto, é preciso que ocorra uma efetiva interação com o fazer
musical, na integração de corpo e mente, de prática e teoria, enfatizando a
pesquisa, a exploração de possibilidades e a criação que, dentre outros, são
aspectos considerados essenciais ao processo de educação (BRITO, 2004, p.
123).

Brito (2007) também propõe uma educação musical que propicie experiências em que o "escutar/fazer/pensar/significar música" esteja presente de forma integradora, da mesma forma que Koellreutter (2007) e Gainza (2002; 2013) incitam a busca de um ensino e uma aprendizagem musical integradores das múltiplas dimensões da música e das outras artes.

Há também sintonia das ideias de Brito com o conceito de consciência e a concepção koellreutteriana de que a "música é, em primeiro lugar, uma contribuição para o alargamento da consciência e para a modificação do homem e da sociedade" (KOELLREUTTER, 1997h, p. 72) e com a concepção de Gainza (2002, p. 67; 2013, p. 64) de que a música é uma experiência multidimensional e a educação musical deve se fundamentar em uma prática que integre o movimento, a criatividade e a consciência. 
Entendemos que fazer música é uma das formas de manifestação da consciência, reconhecendo sua propriedade de criar conexões, em processos contínuos e dinâmicos. Estendemos e aplicamos essa proposição aos distintos e singulares modos de fazer/pensar música, que envolvem escutar, produzir, refletir (BRITO, 2007, p. 3).

Muito enfatizada nos textos de Brito (2004; 2007; 2009), a ideia da singularidade de cada criança e de cada situação educacional, que transcendem o próprio ensinar música, também dialoga com os princípios de pedagogia aberta defendido por Gainza $(2002 ; 2013)$ e com uma das máximas de Koellreutter - "apreender do aluno o que ensinar" - explicitada em diversos textos da autora: "[...] mais do que meramente pretender ensinar música, nosso propósito é escutar e respeitar o processo de reinvenção de cada criança, caminhando juntos com ela" (BRITO, 2007, p. 70).

O pensamento de Brito sobre as invenções das crianças, sobre o qual ela discorre amplamente em sua tese de doutorado, tem grande relevância para a reflexão sobre o espaço da criação nas aulas de piano, objetivo primeiro desta dissertação.

Ao afirmar que as crianças se relacionam com o sonoro e o musical a partir de muitas possibilidades, sejam elas de escuta, exploração sonora, contato com instrumentos musicais ou mídias eletrônicas etc., a educadora se detém nas criações musicais das crianças, valorando-as e delas fazendo emergir conhecimentos sobre o fazer musical infantil. Crianças de qualquer idade, mas principalmente na primeira infância, inventam canções com os temas mais diversos, revelando "os seus modos de ser e estar: consigo mesmas, com o outro, com a família, com a sociedade etc." (BRITO, 2007, p. 184).

Brito (2007, p. 184) considera que é possível "ler", nas criações instrumentais das crianças, aspectos musicais e extramusicais, como a maneira com que a criança estruturou seu pensamento, suas relações com o ambiente, maior ou menor consciência em relação ao espaço-tempo, se predomina o conhecimento intuitivo ou intelectual, como se relaciona com a técnica dos instrumentos e com os códigos de registro, entre muitos outros aspectos. Dessa forma, a criança vai construindo e transformando seu conhecimento musical, como ela explicita a seguir:

Por meio desse jogo, o conhecimento se constrói e se transforma. Intuição e conhecimento específico, liberdade e domínio de regras, exploração, invenção e imitação convivem em produções que enfatizam um ou mais aspectos, dependendo não só da vivência e da maturidade das crianças, como do maior ou menor estímulo ao fazer, ou ainda, da orientação, quando é o 
caso. As criações musicais são manifestações da consciência [...] São experiências vivas que integram o sentir, o perceber, o pensar, o agir, colocando em relação o sujeito e o objeto, o "eu" e o "nós", o indivíduo e o coletivo (BRITO, 2007, p. 184-185).

A apropriação da linguagem musical por meio de processos criativos, como expressão e conhecimento, valorizados por Brito e tônica também dos textos de Koellreutter e de Gainza, é também abordada pela pianista Moema Craveiro Campos, outra referência desta dissertação.

\section{Piano: instrumento de livre expressão - Moema Craveiro Campos}

No livro A educação musical e o novo paradigma, Moema Craveiro Campos defende uma proposta de educação musical por meio do ensino de piano que visa primordialmente contribuir para a formação do ser humano do novo milênio, valorizando a criatividade de cada um, desenvolvendo aspectos espirituais (criação e expressão musical), mentais/intelectuais (conhecimento de diferentes escritas musicais) e físicos/técnicos (preparação dos dedos para livre expressão do indivíduo) a partir da música (CAMPOS, 2000, p. xxi).

Afinada com as ideias apresentadas anteriormente, Campos (2000) considera o novo milênio um momento de transformação do pensamento mecanicista e fragmentado do Ocidente, destacando as descobertas da física quântica, a ideia de inteligências múltiplas e inteligência emocional, a transdisciplinaridade e o construtivismo na educação, a visão junguiana do homem e, principalmente, a aproximação do Ocidente e do Oriente como expoentes de um novo "estar no mundo", que possibilita a complementação das dualidades e a busca pela inteireza do ser. Ao acreditar na necessidade de um pensamento holístico para a educação musical, Campos critica o ensino tradicional de piano que não oferece espaço para a expressão e a criação, priorizando a leitura e o tocar sem erros, que passam a ser o grande objetivo do estudante. Segundo ela, na educação musical, raramente respeita-se e se trabalha “o espaço para a pesquisa da linguagem, que se desenvolve pela 'garatuja musical' ao ‘desenho musical elaborado' e 'abstração' (se é que podemos comparar com o que ocorre no processo do desenho)" (CAMPOS, 2000, p. 4).

Sua proposta educacional para o ensino do piano parte do princípio de que esse deve ser compreendido como um instrumento, um meio para a expressão musical, daí a 
importância de se desenvolver a musicalidade, a sensibilidade e a personalidade do aluno e não se restringir ao objetivo de formar um virtuose.

Depois de discorrer sobre as novas concepções de educação musical do século XX, inclusive citando Gainza e Koellreutter, e destacar a contribuição da inserção da música popular na educação pianística, que exige dos instrumentistas um aguçamento da percepção e do conhecimento harmônico e capacidade de improvisação, Campos (2000, p. 36-39) aponta a importância da participação do aluno como criador e investigador, não só como intérprete.

Em sintonia com as recomendações de Koellreutter e Gainza sobre a postura do professor e o momento de se ensinar os conceitos musicais, Campos (2000, p. 46-47), fundamentando-se no trabalho de Paynter e Aston (1985), indica que, num contexto que valorize a criatividade, "o professor deverá encorajar os alunos a serem artistas, verdadeiros criadores, aproveitando seu interesse natural pela música, e introduzir a informação apenas quando se fizer necessária".

Também em consonância com as ideias de Brito (2007), a pianista defende a integração das diversas formas de se pensar e fazer música:

Ideal seria que em cada aula sempre houvesse relação entre história da
música, teoria, solfejo, percepção, criação, interpretação, escrita e leitura,
dando, com isso, oportunidade ao estudante de vivenciar a música de
maneira integrada, sem a inadequada compartimentalização tão comum na
educação musical tradicional (característica do antigo paradigma)
(CAMPOS, 2000, p. 51).

Ao discorrer mais especificadamente sobre o ensino de piano, Campos destaca que o professor deve estimular a construção de uma intimidade do aluno com o piano, promovendo o primeiro contato a partir da exploração das possibilidades sonoras do instrumento, o que lhe permitirá, mais tarde, maior liberdade de expressão. Observar a mecânica do instrumento, ouvir os sons e buscar uma relação afetiva com eles, percebendo suas impressões e sensações, explorar o som das cordas, sentir sua vibração, usar diferentes materiais, como baquetas ou as próprias unhas, buscando diferentes sons, usar os pedais e ouvir atentamente seus efeitos sonoros, descobrindo os sons harmônicos - todas essas possibilidades aproximam o aluno do instrumento e da linguagem musical. Segundo Campos (2000, p. 76-77), "ao usar a criatividade na exploração do instrumento, associada à aprendizagem tradicional, teremos uma realização musical mais satisfatória, expressiva e prazerosa”. 
Outro importante aspecto do ensino de piano que a autora sustenta é a construção de uma afetividade com o piano e, por conseguinte, com a música. Para ela, o prazer de tocar está intimamente relacionado à relação afetiva com a música, e essa última está ligada ao interesse do aluno:

[...] [como] se a chave para o prazer de fazer música fosse a realização e a satisfação de sentir que "eu posso" realizar o que "eu gosto". E assim a conquista diária do instrumento, as dificuldades a vencer ficam menores. $\mathrm{O}$ prazer da vitória amplia-se, à medida em que se toma conhecimento da música e de si, ao vencer os obstáculos (CAMPOS, 2000, p. 79).

Campos (2000, p. 79-80) opina sobre a postura do professor, convergindo com as ideias já expostas de Koellreutter, Gainza e Brito:

O professor, estando alerta em atender ao aluno, pode encontrar sempre propostas que partam do seu interesse, ou ainda oferecer-lhe algo que lhe dê motivação. [...] A melhor postura que o professor poderá ter sempre é a de observador, alerta aos menores movimentos de cada aluno, ágil a oferecer sugestões de novas e interessantes conquistas, além de soluções. Essa é mais uma oportunidade de crescimento, tanto do professor quanto do aluno.

Como etapa seguinte ou simultânea à pesquisa sonora do instrumento, Campos considera a improvisação como fundamental não só na formação musical do pianista, mas na do indivíduo, e afirma:

Em uma improvisação musical não existe o "erro". Sua maior importância está no fato de ser ela parte de um processo do desenvolvimento musical, cuja base são os conteúdos sensorial, criativo, emocional na estruturação da linguagem. [...] Ao realizar pesquisa de elementos e percepção da linguagem musical, além de ser também exercício de imaginação que permite o aflorar expressivo de ideias musicais, a improvisação é uma prática de grande importância para o indivíduo (CAMPOS, 2000, p. 102).

Por fim, Campos também apoia a ideia da apropriação da linguagem musical a partir de processos criativos, sem prescindir dos aspectos valorizados no ensino tradicional - leitura, técnica e repertório -, buscando uma integração, como observa-se na proposição a seguir:

A improvisação deveria ser vivenciada juntamente com cada conceito teórico introduzido. Se isso ocorresse, estaríamos, todos os músicos, improvisando no mesmo nível de dificuldade técnica que interpretamos peças de outros autores. [...] Seria dar chance à utilização de dois canais de aprendizagem ao mesmo tempo - razão e intuição. Pela interpretação dos signos das peças previamente escritas, precisão de leitura, objetividade e destreza na decodificação, exercitamos a razão, ficando a cargo da intuição a expansividade da imaginação, a liberdade expressiva do sentimento e da ideia musical (CAMPOS, 2000, p. 110). 
Finalizando este capítulo, apresento alguns estudos recentes sobre criatividade na educação musical a partir dos conceitos de aprendizagem criativa, possibility thinking e a voz das crianças. Começo, porém, com algumas das contribuições da psicologia para o estudo da criatividade.

\section{Aprendizagem criativa}

Desde a segunda metade do século XX, o interesse pelo tema da criatividade no campo da educação vem crescendo, a improvisação e a composição musical vêm ganhando espaço nas pesquisas e muitas das novas perspectivas têm sido construídas a partir do diálogo com a psicologia.

Há décadas, a psicologia se dedica a pesquisar a criatividade. As psicólogas Eunice Soriano de Alencar e Denise de Souza Fleith, em seu livro Criatividade - múltiplas perspectivas, apresentam diversas contribuições dessa pesquisa ao longo do século XX. Destaco a seguir algumas das mais recentes e que mais interessam a esta dissertação.

Segundo as autoras, na década de 1950, começou a surgir um grande interesse por esse tema, e pesquisadores como Barron (1955), ${ }^{60}$ Guilford (1967), ${ }^{61}$ MacKinnon (1962) ${ }^{62}$ desenvolveram estudos que pretendiam determinar as características do pensamento criativo e formas de identificá-lo. Na década seguinte, o foco das pesquisas era investigar possíveis estratégias para desenvolver o potencial criativo das pessoas, baseando-se na concepção do movimento humanista, do qual Maslow $(1968)^{63}$ e Rogers (1959) ${ }^{64}$ eram referência, de que a criatividade é um potencial inerente a todos os indivíduos.

A partir dos anos 1970, por influência da psicologia cognitiva, o interesse das pesquisas convergiu para o estudo do ato criativo em suas diversas manifestações e para as

\footnotetext{
${ }^{60}$ BARRON, P. The disposition toward originality. Journal of Personality and Social Psychology, n. 51, p. 478$485,1955$.

${ }^{61}$ GUILFORD, J. P. The nature of human intelligence. Nova York: Mc-Graw-Hill, 1967.

${ }^{62}$ MACKINNON, D. W. The nature and nurture of creative talent. American Psychologist, n. 17, p. 484-495, 1962.

${ }^{63}$ MASLOW, A. H. Toward a psychology of being. 2. ed. Princeton, NJ: Van Nostrand, 1968.

${ }^{64}$ ROGERS, C. R. Toward a theory of creativity. In: ANDERSON, H. H. (Org.). Creativity and its cultivation. Nova York: Harper \& Row, p. 69-82, 1959.
} 
possíveis interferências do contexto social no ato de criar. As psicólogas destacam as teorias de Feldman, Csikszentmihalyi e Gardner (ALENCAR; FLEITH, 2009, p. 62).

A partir da década de 1980, predominou a ideia de que a criatividade só pode ser compreendida a partir da investigação tanto das variáveis internas do indivíduo quanto das externas a ele. Segundo Csikszentmihalyi (1996, p. 23), a criatividade é "resultado da interação dos pensamentos do indivíduo e do contexto sociocultural [...] [e] deve ser compreendida não como um fenômeno individual, mas como um processo sistêmico".

A pesquisadora inglesa Anna Craft, professora de educação na Universidade de Exeter e diretora do Open Creativity Centre, afirma que, desde o início do século XXI, cada vez mais se reconhece que a criatividade tem que ser compreendida dentro do contexto cultural (CRAFT, 2011, p. 20).

Em seu livro Creativity and education futures: learnig in a digital age, Craft discorre sobre o que provocou a crescente valorização da criatividade no mundo Ocidental em vários contextos e áreas do conhecimento, como na ciência, na tecnologia, nas artes, na educação e mesmo na vida cotidiana, desde o final do século XX. Com enfoque especial na educação, ela relaciona esse despertar para a criatividade aos aspectos econômico, social, tecnológico e até ecológico e espiritual. Detendo-se nos três primeiros, aponta a interdependência da economia mundial a partir da globalização e a relação complexa entre Estado e iniciativa privada, que causa grandes mudanças nas necessidades de consumo, como disparadores da procura por profissionais mais criativos, que inovem o mercado e sejam flexíveis para trabalhar frente às incertezas. Em relação ao aspecto social, a autora destaca as grandes mudanças na sociedade ocidental, em que padrões sociais de comportamento estão cada vez mais ligados a preferências individuais do que à tradição, consequência do aumento da complexidade do dia a dia dos indivíduos por conta de estruturas familiares diversas e do complexo engajamento social, que demanda e oferece cada vez mais oportunidades, valorizando as escolhas pessoais para condução da própria vida. Esses fatores econômicos e sociais provocaram mudanças na educação, que, agora, deveria auxiliar crianças e jovens a exercitarem sua imaginação e potencial criativo para lidar com o grande número de escolhas. Por fim, Craft (2011, p. 19-24) aponta as mudanças tecnológicas das últimas décadas e a total integração das tecnologias digitais à vida do homem ocidental, afirmando que a criatividade que exigem e oferecem é indiscutível. 
A pesquisadora observa que, embora a educação valorize a criatividade, é importante reconhecer e problematizar os dilemas da mercantilização da educação e defende que a criatividade esteja pautada em valores éticos. Ela incita os educadores a se conscientizarem de sua responsabilidade pelo desenvolvimento individual e coletivo do potencial criativo de seus alunos (CRAFT, 2011, p. 33).

Dentre inúmeras abordagens e diferentes aspectos levantados nas pesquisas sobre a criatividade, a educadora musical Viviane Beineke apresenta a diferenciação que Anna Craft faz dos trabalhos que abordam o tema: o ensino criativo, o ensino para a criatividade e a aprendizagem criativa. Por ensino criativo entende-se "as abordagens imaginativas que tornem a aprendizagem mais interessante e efetiva, focalizando a atuação do professor", o ensino para a criatividade se refere aos trabalhos que, com foco nos alunos, analisam "o desenvolvimento do pensamento criativo dos estudantes", e a aprendizagem criativa, presente nas pesquisas mais recentes, procura "capturar tanto a perspectiva do professor como a dos alunos" (CRAFT, 2005 $5^{65}$ apud BEINEKE, 2009, p. 74).

Em artigo de 2004, "Teaching creatively and teaching for creativity: distinctions and relationships", Anna Craft e Bob Jeffrey, também pesquisador do tema, apontam que as pesquisas sobre ensino criativo foram relevantes nas décadas de 1990 e 2000 a ponto de mudar o currículo oficial da Inglaterra, que, desde então, orienta a incorporação da criatividade em todas as disciplinas. Ao mesmo tempo, os autores discorrem sobre a relação entre ensinar criativamente e ensinar para a criatividade, indicando aos pesquisadores que, ao distingui-los, é importante definir claramente as circunstâncias a serem estudadas, pois as duas formas estão intrinsicamente inter-relacionados. Sugerem, então, que "a constituição de práticas pedagógicas criativas podem ser mais transparentes se o foco se encontrar tanto no professor como no aluno" ${ }^{66}$ (JEFFREY; CRAFT, 2004, p. 14-15, tradução nossa), apontando uma nova perspectiva dos estudos sobre criatividade: a aprendizagem criativa.

De acordo com Beineke (2009, p. 74), o conceito de aprendizagem criativa, que começou a ser construído no início do século XXI, ainda está se definindo, demandando mais pesquisas para que se chegue a uma maior compreensão, porém já tem sido estudado e aplicado. Parte da definição está na própria expressão, que aponta, “de um lado, o

\footnotetext{
${ }^{65}$ CRAFT, A. Creativity in Schools: tensions and dilemmas. London: Routledge, 2005.

66 “ [...] the constitution of creative pedagogic practices may be more transparent if the focus is on the teacher and on the learner" (JEFFREY; CRAFT, 2004, p. 14-15).
} 
envolvimento dos alunos em experimentação, inovação e invenção; e, de outro, é enfatizada a investigação intelectual" (CRAFT; CREMIN; BURNARD, 2008 ${ }^{67}$ apud BEINEKE, 2012, p. 49). A educadora brasileira destaca que essa abordagem apresentou uma mudança em relação à ideia da criatividade, antes relacionada somente a certas habilidades ou traços de personalidade. Segundo essa nova compreensão, a criatividade surge em domínios específicos e é necessário aprofundar-se em seu conhecimento para que ela possa emergir (BEINEKE, 2012, p. 49).

Beineke também apresenta a definição de aprendizagem criativa de David Henry Feldman, doutor em psicologia do desenvolvimento:

Segundo Feldman $(2008)^{68}$, o conceito de criatividade, dentro da expressão aprendizagem criativa, supõe que é a intenção de transformar o mundo de alguma maneira que torna um esforço potencialmente criativo, e se torna criativo quando é julgado como tal. Quanto à aprendizagem, no conceito de aprendizagem criativa, o autor define que ela ocorre dentro de domínios específicos, envolvendo a aquisição de técnicas, habilidades, informação e tecnologia que potencializam o desenvolvimento da criatividade (BEINEKE, 2009, p. 75).

Por fim, diante dos aspectos tratados sobre criatividade na educação, Beineke corrobora com a opção pela aprendizagem criativa nas pesquisas sobre criatividade e sobre composição musical no ensino de música, optando por:

[...] olhar para a criatividade sob diversos ângulos, buscando uma perspectiva teórica que não fragmente o conhecimento e possa contemplar os vários aspectos envolvidos na prática musical em sala de aula, incluindo o conhecimento sobre as perspectivas das crianças e do professor sobre a criatividade em atividades de composição musical (BEINEKE, 2009, p. 73).

\section{Possibility thinking ${ }^{69}$}

Ao lado de Anna Craft, as renomadas pesquisadoras Pamela Burnard e Teresa Cremin vêm desenvolvendo pesquisas sobre aprendizagem criativa e possibility thinking. Segundo elas:

${ }^{67}$ CRAFT, A.; CREMIN, T.; BURNARD, P. Creative learning: an emergent concept. In: (Eds.). Creative learning 3-11: and how to document it. Stoke on Trent: Trentham, 2008. p. xix-xxiv.

68 FELDMAN, D. H. Foreword: Documenting creative learning, changing the world. In: CRAFT, A.; CREMMIN, T.; BURNARD, P. (Eds.). Creative learning 3-11: and how to document it. Sterling: Trentham Books Limited, 2008, p. xiii-xvii.

${ }^{69}$ Mantive essa expressão no original por acreditar que a tradução literal trairia a totalidade de seu sentido. 
[...] "o pensamento que considera diversas possibilidades" (possibility thinking) tem sido conceituado como central na aprendizagem criativa, embora seu papel ainda não esteja totalmente claro em relação ao envolvimento com a aprendizagem das crianças e às estratégias pedagógicas dos professores [...] ele pode ser compreendido a partir de uma tripla perspectiva: das pessoas ou agentes, dos processos e dos domínios, envolvendo tanto o reconhecimento como a resolução de problemas $^{70}$ (CREMIN; BURNARD; CRAFT, 2006, p. 108-109, tradução nossa).

Anna Craft e Bob Jeffrey definem possibility thinking da seguinte maneira:

"O pensamento que considera diversas possibilidades" (possibility thinking) engloba a resolução de problemas como em um quebra-cabeças, isto é, encontrar rotas alternativas para transpor uma barreira, fazer perguntas e identificar problemas e questões. Os dois primeiros tipos frequentemente envolvem experimentação e investigação [.... $]^{71}$ (JEFFREY, CRAFT, 2004, p. 9 , tradução nossa).

Mesmo sem a exata definição de possibility thinking, diversas pesquisas vêm sendo realizadas no sentido de indicar uma prática pedagógica que promova diversas possibilidades do pensar, o que caracteriza o pensamento criativo. Cremin, Burnard e Craft (2006, p. 108109) mencionam um projeto empreendido pelo Qualifications and Curriculum Authority (QCA), ${ }^{72}$ aplicado em dez países da Europa no período de dois anos, para estudar a criatividade, ajudar os professores a descobri-la em si mesmos e promovê-la em sala de aula.

Como resultado da referida pesquisa, as autoras citam elementos que caracterizam a criatividade, como conceber questões, fazer conexões, ser imaginativo, explorar opções e empenhar-se em reflexões e avaliações críticas, e abordagens pedagógicas que possibilitem a criatividade: estabelecer critérios para o êxito, aproveitar o inesperado sem perder de vista o objetivo original, fazer perguntas abertas, encorajar ideias abertas e reflexões críticas e rever, regularmente, o trabalho em andamento. Também é relevante que o estudo apontou que conceitos como inovação, originalidade, domínio e controle estavam associados à criatividade nas escolas primárias e considerou imaginação ou possibility thinking como elemento central da criatividade (CREMIN; BURNARD; CRAFT, 2006, p. 108).

\footnotetext{
70 "Possibility thinking has been conceptualized as being central to creative learning although its role, as manifest in the learning engagement of children and the pedagogical strategies of practitioners has not been fully illuminated [...] that it can be understood from the tripartite perspective of people or agents, processes and domains and that it involves both problem finding and problem solving" (CREMIN; BURNARD; CRAFT, 2006, p. 108-109).

71 "Possibility thinking includes problem solving as in a puzzle, finding alternative routes to a barrier, the posing of questions and the identification of problems and issues. The first two types often involve experimentation and investigation [...]" (JEFFREY; CRAFT, 2004, p. 9).

${ }^{72}$ QCA era o setor do Departamento de Educação do Reino Unido responsável pela manutenção e desenvolvimento do currículo nacional e pelos exames e avaliações (QUALIFICATIONS [...]).
} 
As pesquisadoras também falam sobre o relatório do National Advisory Committee on Creative and Cultural Education, que sugere que os professores estimulem alguns atributos, como:

[...] correr riscos e fazer julgamentos independentes, além de comprometimento, resiliência, motivação intrínseca e curiosidade, observando que, para ensinar pela criatividade, os professores devem identificar os aspectos criativos que mais se destacam nas crianças e estimular esse potencial ${ }^{73}$ (CREMIN; BURNARD; CRAFT, 2006, p. 111, tradução nossa).

Em outro estudo, Jeffrey e Craft (2004, p. 8-9) sugerem uma abordagem pedagógica em que ensino e aprendizagem aconteçam a partir da coparticipação de professores e alunos, num ambiente que se estimulem perguntas, identificação de problemas e questões em conjunto e o debate, inclusive deixando os alunos controlarem situações; o incentivo dessa prática também faz parte das indicações pedagógicas de Cremin, Burnard e Craft.

Para fomentar possibility thinking e a consequente aprendizagem criativa, as pesquisadoras apontam condutas e direcionamentos centrais para essa nova abordagem pedagógica: "standback, learner agency and creating time and space" (CREMIN; BURNARD; CRAFT, 2006, p. 113-117). Standback refere-se a uma postura pedagógica do professor, na qual ele se mantém propositalmente à parte da ação dos alunos, como observador ativo e disponível, apoiando-os em sua capacidade de agentes do próprio aprendizado. Learner agency está relacionado justamente a essa capacidade, que implica priorizar e possibilitar sua atuação nas atividades, fazendo escolhas, identificando e resolvendo problemas que possam aparecer, e demanda professores que promovam uma liberdade com muitos desafios. Creating time and space são recursos fundamentais para o desenvolvimento do pensamento criativo: "tempo para pensar, imaginar, perguntar, experimentar e refletir sobre o trabalho em processo (work in progress) é essencial para capacitar os jovens estudantes a pensar seu caminho à frente"74 (CREMIN; BURNARD; CRAFT, 2006, p. 113-117, tradução nossa).

\footnotetext{
73 “[...] risk taking, independent judgement, commitment, resilience, intrinsic motivation and curiosity, noting that in order to teach for creativity, teachers must identify children's creative strengths and foster their creative potential" (CREMIN; BURNARD; CRAFT, 2006, p. 111).

74 "Time to think, imagine, ask questions, experiment and reflect upon work in progress was seen as central to enabling the young learners to possibility think their way forwards" (CREMIN; BURNARD; CRAFT, 2006, p. 113-117).
} 


\section{A voz das crianças e o espaço da criação}

É importante destacar que, ao abrir espaço para que as crianças sejam agentes do seu aprendizado, como defendem as pesquisadoras inglesas, um outro aspecto vira foco dos estudos de educação musical: a escuta das voz das crianças. ${ }^{75}$ Segundo Beineke, “o conceito de voz do aluno vem se tornando corrente nas pesquisas com crianças e está-se descobrindo que elas têm muito a dizer sobre o que e como pensam" (BURNARD, 2006 ${ }^{76}$ apud BEINEKE, 2011, p. 93, grifos do original). No Brasil, esse novo olhar para a criança, implícito no conceito de voz do aluno, aparece em trabalhos que ressaltam a importância de se ouvirem a música e as ideias de música ${ }^{77}$ das crianças, como Beineke (2009; 2011), Brito (2007) e Santos (2006). Em seu artigo "Aprendizagem criativa na escola: um olhar para a perspectiva das crianças sobre suas práticas musicais", Beineke discorre sobre esse novo foco de pesquisa:

$\mathrm{Na}$ área de educação musical e, mais especificamente, no campo das pesquisas sobre criatividade e composições infantis, observa-se uma preocupação progressiva com perspectivas educacionais que procuram ouvir as crianças, valorizando seus conhecimentos e maneiras de fazer e significar suas experiências musicais dentro e fora da escola. Tradicionalmente, as práticas musicais das crianças são entendidas sob a óptica dos adultos, sem considerar que as crianças podem ter uma compreensão diferente sobre música, como revelam as pesquisas de Barret $\left(2003 ;{ }^{78} 2011\right),{ }^{79}$ Brito (2007), Burnard $\left(2002 ;{ }^{80} 2006\right),{ }^{81}$ Campbell $\left(2006 ;{ }^{82} 2011\right),{ }^{83}$ Custodero (2007), ${ }^{84}$

\footnotetext{
${ }^{75}$ Há algumas décadas, surgiu na sociologia uma subárea voltada para o estudo da infância como fenômeno social, apontando a invisibilidade das crianças e, portanto, o fato de não se lhes dar voz na sociedade ocidental. Essa visão da infância não será abordada aqui, porque, apesar de haver pontos de contato com algumas ideias expostas neste capítulo, os referenciais teóricos desta pesquisa vêm de outras áreas do conhecimento como educação musical e psicologia. No entanto, caso haja interesse, pode-se pesquisar a produção acadêmica dos seguintes autores: o dinamarquês Jens Qvortrup, os ingleses Alan Prout, Allison James e Chris Jenks, o italiano William Corsaro, as francesas Cléopâtre Montandon, Régine Sirota e Julia Delalande, o português Manuel Jacinto Sarmento e a brasileira Jucirema Quinteiro.

${ }^{76}$ BURNARD, P. Understanding children's meaning-making as composers. In: DELIÈGE, I.; WIGGINS, G. A. (Eds.). Musical creativity: multidisciplinary research in theory and practice. New York: Psychology Press, 2006. p. 111-133.

${ }^{77}$ Ideias de música é uma expressão de Brito (2003; 2007).

${ }^{78}$ BARRET, M. S. Freedoms and constraints: constructing musical worlds through the dialogue of composition. In: HICKEY, M. (Ed.). Why and how to teach music composition: a new horizon for Music Education. Reston: MENC - The National Association for Music Education, 2003. p. 3-27.

${ }^{79}$ BARRET, M. S. Towards a cultural psychology of music education. In: BARRET, M. S. (Ed.). A cultural psychology of Music Education. New York: Oxford, 2011. p. 1-15.

${ }^{80}$ BURNARD, P. Investigating children's meaning-making and the emergence of musical interaction in group improvisation. British Journal of Music Education, v. 19, n. 2, p. 157-172, 2002.

${ }^{81}$ BURNARD, P. Understanding children's meaning-making as composers. In: DELIÈGE, I.; WIGGINS, G. A. (Eds.). Musical creativity: multidisciplinary research in theory and practice. New York: Psychology Press, 2006, p. 111-133.

${ }^{82}$ CAMPBELL, P. S. Global practices. In: MCPHERSON, G. (Ed.). The child as musician: a handbook of musical development. Oxford: Oxford University Press, 2006. p. 415-437.
} 
Marsh $\left(2008 ;{ }^{85} 2011\right),{ }^{86}$ Young $(2008){ }^{87}$ e Younker (2009) ${ }^{88}$ entre outras [...] Contrariando pesquisas centradas na visão musical e educacional dos adultos, vêm sendo envidados esforços para compreender as perspectivas das crianças nos processos educacionais, entendendo-as como agentes da sua aprendizagem (BEINEKE, 2011, p. 93).

Brito (2007) chama atenção para a limitação da concepção de "uma única ideia de música" - muito difundida e pouco questionada, mesmo nos dias atuais - diante das muitas músicas e ideias de música que há no mundo e que se transformam com o passar do tempo, reconhecendo também a música própria das crianças, quase nunca considerada. A pesquisadora e educadora musical Fátima Carneiro Santos, ao refletir sobre uma proposta de criação musical com crianças a partir de sons da rua, corrobora com a afirmação de Brito e defende a necessidade de uma educação musical que acolha as muitas ideias de música:

[...] a possibilidade de se pensar uma educação musical que leva em conta outras sonoridades e outros fazeres musicais e que opera basicamente através da criação, entendendo o ato de criação enquanto um ato de resistência, que faz proliferar diferenças, condição fundamental para a atualização de outras ideias de música. [...] uma ideia de educação musical que não apenas discrimina e escolhe sons, mas que também se determine em função de uma escuta que compõe e de um campo sonoro o mais amplo possível, permitindo o desejo de músicas não apenas formatadas por modelos dados $a$ priori e possibilitando o questionamento e a ampliação da própria ideia de música (SANTOS, 2006, p. xiii).

Na mesma direção do pensamento de Brito (2007) e Santos (2006), Beineke (2009) procurou conhecer as ideias de música das crianças numa aula de música de uma escola de ensino básico, num processo de aprendizagem criativa em que elas compuseram suas músicas e pensaram sobre possíveis ideias de música. Santos (2006, p. 120) evidencia a disponibilidade das crianças, agentes em sua escuta sonora e criação musical, 'para 'pensar'

\footnotetext{
${ }^{83}$ CAMPBELL, P. S. Musical enculturation: sociocultural influences and meanings of children's experiences in and through music. In: BARRET, M. S. (Ed.). A cultural psychology of music education. New York: Oxford, 2011. p. 61-81.

${ }^{84}$ CUSTODERO, L. A. Origins and expertise in the musical improvisations of adults and children: a phenomenological study of content and process. British Journal of Music Education, n. 24, p. 77-98, 2007.

${ }^{85}$ MARSH, K. Child. The musical playground: global tradition and change in children's songs and games. Oxford: Oxford University Press, 2008.

${ }^{86}$ MARSH, K. Meaning-making through musical play: cultural psychology of the playground. In: BARRET, M. S. (Ed.). A cultural psychology of Music Education. New York: Oxford, 2011. p. 41-60.

cultural psychology of Music Education. New York: Oxford, 2011. p. 41-60.

87 YOUNG, S. Collaboration between 3 and 4-year-olds in self-initiated play on instruments. International Journal of Educational Research, v. 47, p. 3-10, 2008.

${ }^{88}$ YOUNKER, B. A. Composing in the classroom: the journey of five children. In: KERCHNER, J. L.; ABRIL, C. R. (Eds.). Musical experience in our lives: things we learn and meanings we make. Maryland: Rowman \& Littlefield Publishers, 2009. p. 145-162.
} 
os sons da rua a partir de uma escuta que revela outras possibilidades sonoras que não apenas aquelas mais habituais", facilitando a percepção e a compreensão "de a rua conter 'músicas' (ou ideias de música) ou ser ouvida como música, por que não?”. E Brito complementa:

Reconhecer e respeitar a produção musical infantil implica em reconhecer que a música é um sistema aberto e dinâmico e que as crianças elaboram e reelaboram dinamicamente suas ideias de música, em planos que consideram a condição de emergência. Tais ideias abarcam as representações mentais acerca da questão, o modo como elas elaboram e lidam com os conceitos envolvidos, a prática e os significados conferidos ao fazer musical. [...] Mais importante, no entanto, é atentar para a convivência de ideias de música, abrindo ouvidos - também - para uma espécie de musicriança: as crianças transmutadas em sons (BRITO, 2007, p. 77/80).

Para que se valorize as ideias de música das crianças é imprescindível que haja uma disponibilidade anterior para ouvir as vozes das crianças. Nos dizeres de Brito, ao expor os materiais que seriam analisados em sua tese de doutorado, tal necessidade fica evidente:

Selecionamos reflexões, comentários e diálogos de crianças de idades variadas, os quais remetem a diversas questões. Nossa intenção é indicar a conexão presente entre a prática musical e a reflexão das crianças, especialmente quando - nos territórios da educação - permitimos que elas compartilhem pensamentos e descobertas, reveladores de sua sensibilidade e de sua capacidade de elaborar e transformar (BRITO, 2007, p. 94, grifos nossos).

Beineke também revela essa postura ao comentar sobre as ideias das crianças que aparecem em um dos estudos de caso de sua tese de doutorado: "Essas ideias de música são construídas intersubjetivamente entre as crianças e a professora, contemplando a interação entre aqueles que participam da sua construção" (BEINEKE, 2009, p. 138). Na mesma perspectiva de outros autores, a pesquisadora amplia o papel do professor quando relaciona sua conduta a possíveis composições das crianças; entre esses autores, cita Berkley $\left(2001 ;^{89}\right.$ $2004)^{90}$ ao afirmar que:

[...] o ambiente estabelecido pelo professor para a realização dos trabalhos, incentivando os alunos a adquirirem confiança no seu fazer musical e para explorarem novas ideias, é um fator fundamental na qualidade das atividades de composição. Nesse sentido, estilos abertos de ensino são mais favoráveis para o desenvolvimento criativo, à medida que promovem iniciativa, espontaneidade, sensibilidade, flexibilidade e pensamento divergente dos estudantes (BEINEKE, 2009, p. 62-63).

\footnotetext{
${ }^{89}$ BERKLEY, R. Why is teaching composing so challenging? A survey of classroom observation and teachers' opinions. British Journal of Musical Education, v. 18, n. 2, p. 119-138, 2001.

90 BERKLEY, R. Teaching composing as creative problem solving: conceptualizing composing pedagogy. British Journal of Musical Education, v. 21, n. 3, p. 239-263, 2004.
} 
Em sintonia com essas posições, Burnard (2004) analisa um estudo de caso em que alunos de oito anos e seu professor discutem e refletem sobre sua experiência de aprendizado numa aula prática. Nesse estudo, Burnard aponta os diferentes pontos de vista entre as crianças e o professor e ressalta a necessidade dos professores aprenderem essa nova forma de coparticipação, na qual as vozes das crianças são ouvidas:

A criação de oportunidades para compartilhar ideias e discutir diferentes caminhos possíveis, por meio dos quais podemos consultar os alunos e instigá-los a revelarem seu ponto de vista sobre a aprendizagem, é essencial para o desenvolvimento de práticas eficazes. Quando se pensa em aprendizagem, é importante perceber que o professor é um modelo que pode viabiliza e apoia a aprendizagem em sala de aula e a de cada aluno em seu contexto familiar. É importante também aceitar que, embora a abordagem mais comum (com base nas teorias socioconstrutivistas) seja aquela em que o professor ensina o aluno como aprender, na verdade, as salas de aula serão ocupadas com conversas entre os alunos, que aprenderão uns com os outros. Uma das lições mais difíceis que os professores têm de aprender e praticar é entender o ponto de vista dos alunos, seja qual e quando for ${ }^{91}$ (BURNARD, 2004, p. 32, tradução nossa).

Burnard também incentiva essa postura do professor em sua proposta de prática pedagógica, assim como Cremin e Craft, no artigo citado anteriormente. Por fim, a coparticipação proposta parece ser um caminho a ser aprendido e trilhado por professores e alunos que se disponham a construir um modo de ensino e aprendizado conectado às ideias mais contemporâneas de educação, das quais a criatividade é um dos carros-chefe. Finalizando com a fala de Brito:

A parceria com os educadores (em se tratando do acontecimento musical nos planos da educação) pode contribuir com o enriquecimento e a ampliação do fazer musical, que se transforma pelo agregar de complexidade. Para tanto, é preciso que, a exemplo do que propôs Humberto Maturana (1990), ${ }^{92}$ o professor se aceite como guia em um espaço de convivência marcado pela aceitação recíproca, produzindo uma dinâmica na qual todos mudam juntos. Escutando, respeitando e interagindo com os alunos, ele permitirá que o acontecimento musical seja efetivo, "de verdade", por assim dizer (BRITO, 2007, p. 183).

\footnotetext{
91 "The promotion and creation of opportunities for sharing ideas and discussing different ways we can consult pupils and elicit pupils' views on learning is an essential element in developing effective practice. The realization that the teacher will be a powerful model for, and the facilitator of, thinking about learning is important in enabling and supporting learning in both classroom and personal loci. Also important is the acceptance that although the most common approach taken (as based on social constructivist theories) is one in which the teacher teaches the learner how to learn, the reality is that classrooms will be busy with talk and with learners learning from each other. Coming to understand pupils' views on learning, wherever it occurs, and allowing this to happen, may be one of the hardest lessons pre-service and practicing teachers have to learn" (BURNARD, 2004, p. 32).

${ }^{92}$ MATURANA, H. A ontologia da realidade. Belo Horizonte: UFMG, 1990.
} 


\title{
CAPÍTULO 3
}

\section{Reflexões pedagógico-musicais sobre as composições das crianças}

\author{
O conhecimento nada mais é que a aventura pelo mar \\ desconhecido, em busca da terra sonhada. Mas sonhar é coisa que \\ não se ensina. Brota das profundezas do corpo, como a água brota \\ das profundezas da terra. Como mestre só posso então lhe dizer \\ uma coisa: Conte-me teus sonhos, para que sonhemos juntos.
}

Rubem Alves

Neste capítulo, apresento quatro composições, uma livre improvisação e depoimentos de crianças falando sobre seu processo criativo, assim como o respectivo contexto de aula em que cada um foi elaborado. O objetivo de analisar as criações musicais e a fala das crianças é entender melhor o pensamento que orienta o fazer musical infantil e verificar a potencialidade do espaço criador no desenvolvimento do conhecimento musical do aluno de piano. As três crianças autoras dos exemplos são alunas da EMIA (Escola Municipal de Iniciação Artística), onde fazem outros cursos além do de piano.

Antes de apresentar a EMIA, creio que seja necessário esclarecer o sentido da palavra composição utilizado nesta dissertação. De acordo com o Dicionário do Aurélio Online, composição significa "ação de compor um todo juntando as partes; natureza das partes, maneira por que formam o todo; arranjo, disposição, associação, combinação, constituição, organização, estrutura”. Já no Dicionário Houaiss eletrônico (2009), composição é "constituição de um todo; modo pelo qual os elementos constituintes do todo se dispõem e integram; organização". Enfim, criar uma forma a partir de alguns elementos. Ao transpor essa definição para a música, poderia-se dizer que compor música é criar formas sonoras.

No campo da música, há discordância em relação ao uso do termo composição para as invenções das crianças. Em artigo na revista Em pauta, o reconhecido pesquisador e educador musical inglês Keith Swanwick e a pesquisadora e educadora musical brasileira Cecília Cavalieri França abordam a questão de maneira bastante interessante, apontando que alguns pesquisadores, como Fletcher (1987, p. 41$)^{93}$ e Elliott (1995), ${ }^{94}$ consideram a "composição como atividade exclusiva dos grandes mestres da história da música, alienando os estudantes

\footnotetext{
${ }^{93}$ FLETCHER, P. Education and Music. Oxford/New York: Oxford University Press, 1987.

${ }^{94}$ ELLIOTT, D. Music Matters: a new philosophy of music education. New York/Oxford: Oxford University Press, 1995.
} 
dessa forma básica do fazer musical" (FRANÇA; SWANWICK, 2002, p. 9). Citam também a posição contraditória de Harris e Hawkesley, que declaram que considerar como uma composição uma peça de "algumas notas tocadas em um instrumento de percussão" seria uma afirmação "a princípio exagerada para ser levada a sério por alguns músicos”, mas em seguida afirmam que "quando os alunos selecionam e organizam sons em uma peça de música, por mais simples que suas tentativas possam ser, ainda assim estão compondo" (HARRIS; HAWKESLEY, $1989,{ }^{95}$ p. 2-3 apud FRANÇA; SWANWICK, 2002, p. 11).

Em contrapartida, França e Swanwick (2002, p. 9-10) chamam a atenção para a posição de alguns entre os próprios compositores - como Hindemith, Schoenberg, Schafer, Paynter, entre outros - que acreditam "no potencial educativo da composição". Destaco a frase de Paynter sobre a composição: "é a maneira mais certa para os alunos desenvolverem o julgamento musical e compreenderem a noção do 'pensar' musicalmente" (PAYNTER, $1977,{ }^{96}$ p. 18 apud FRANÇA; SWANWICK, 2002, p. 10).

Brito (2005, 2007, 2009) foi outro referencial usado para fundamentar o uso do termo composição para as invenções das crianças. Um dos pontos fundamentais de sua pesquisa são as ideias de música das crianças. A educadora considera que ideias de música coexistem no mundo, pois a música é uma atividade construída num contexto cultural e temporal, portanto uma estruturação de sons e silêncios sempre a partir de um processo dinâmico e singular de percepção e representação do mundo (BRITO, 2005). A partir dessa concepção de música, Brito (2007, p. 68) afirma que "as crianças reconstroem as ideias de música em contínua e permanente transformação", pois são capturadas por elas.

Beineke (2003, p. 91-92) também discorre sobre essa questão, acrescentando uma discussão sobre composição e criação musical. Segundo a pesquisadora, os dois termos são frequentemente considerados sinônimos, mas ela concebe que não o são e que o uso de um ou de outro pode apontar diferentes compreensões por parte dos professores e mesmo em relação às abordagens metodológicas. Ela ainda questiona a ideia estabelecida no ensino mais tradicional de música, que não compreende a criatividade como atributo próprio à atividade musical como um todo, mas concentrada só na composição: nesse contexto, composição e criação são sinônimos. No entanto, aponta para outra concepção de educação musical, na qual

\footnotetext{
${ }^{95}$ HARRIS, R.; HAWKSLEY, E. Composing in the Classroom. Cambridge: Cambridge University Press, 1989.

96 PAYNTER, J. The Role of Creativity in the School Music Curriculum. In: BURNETT, M. (Ed.) Music Education Review: A Handbook for Music Teachers. v. 1, London: Chappell \& Co. Ltd., 1977.
} 
ouvir, reger e interpretar (tocando ou cantando) podem ser ações criativas, assim como compor. Beineke (2003, p. 95-96) usa o termo composição para atividades que possibilitem um "espaço maior para a tomada de decisões musicais, incluindo trabalhos de arranjos e improvisações, individuais ou em grupo, com ou sem notação musical" e adota os termos criação e desenvolvimento criativo para se referir a "uma atitude que deve permear toda a prática educativo-musical, não estando restrita apenas à composição”.

Dessa forma, concordando com as ideias de Brito, a afirmação de Paynter e os argumentos defendidos por França e Swanwick, justifico o uso do termo composição para as invenções musicais analisadas neste capítulo. Para concluir, cito:

\begin{abstract}
As composições feitas em sala de aula variam muito em duração e complexidade de acordo com sua natureza, propósito e contexto; podem ser desde pequenas "falas" improvisadas até projetos mais elaborados que podem levar várias aulas para serem concluídos. Mas, desde que os alunos estejam engajados com o propósito de articular e comunicar seu pensamento em formas sonoras, organizando padrões e gerando novas estruturas dentro de um período de tempo, o produto resultante deve ser considerado como uma composição - independentemente de julgamentos de valor. Essas peças são expressões legítimas de sua vida intelectual e afetiva (FRANÇA; SWANWICK, 2002, p. 11).
\end{abstract}

\title{
3.1 O contexto: a EMIA
}

A EMIA, Escola Municipal de Iniciação Artística, pertence ao Departamento de Expansão Cultural (DEC) da Secretaria Municipal de Cultura da cidade de São Paulo. Seu principal objetivo é a iniciação às artes por meio da integração de música, teatro, dança e artes visuais.

Fundada em 1980, a escola foi estruturada e organizada pela prof ${ }^{a}$ dr $^{\mathrm{a}}$ Marisa Trench Fonterrada, então diretora da Escola Municipal de Música (EMM), e pela professora Maria Eliza Figueiredo Bologna, então coordenadora das Unidades de Iniciação Artística do Departamento de Teatros da Secretaria Municipal de Cultura. Inicialmente, a escola seria um apêndice da Escola Municipal de Música, por isso Marisa Fonterrada foi convidada a elaborar a proposta de uma escola de artes para crianças. Sua sede seria no Parque da Conceição (atual Parque Lina e Paulo Raia), que era uma antiga chácara com grande área verde e três casas recém-desapropriada pela prefeitura em consequência das obras do metrô. Em seu projeto 
inicial, não constava exatamente a integração de linguagens, mas já existia um desejo para tal (FONTERRADA, 2013, informação verbal). ${ }^{97}$

Segundo a educadora musical e psicopedagoga Márcia Lagua de Oliveira, que trabalhou na EMIA desde os primeiros anos da escola:

[...] o objetivo inicial foi oferecer uma escola para as crianças aprenderem música de forma interativa com outras áreas artísticas [...] usar outras linguagens artísticas como recurso para garantir o desempenho das crianças no estudo individual de instrumento, preparando-as para ingressarem na Escola Municipal de Música - EMM (OLIVEIRA, 2006, p. 49-50, grifo do original).

Diante desse objetivo, a maioria dos professores contratados eram de música, mas havia outros de teatro e artes plásticas. No início das atividades, a professora de teatro Claudia Badra coordenou um trabalho de oficinas com os outros professores da escola, constituindo o "primeiro passo para se delinear um trabalho que buscava integrar música, teatro, dança e artes plásticas" (OLIVEIRA, 2006, p. 50). Ao longo do percurso da escola, essas linguagens artísticas foram conquistando cada vez mais espaço, criando contornos definidos e se estruturando. Assim, atualmente, a EMIA oferece um trabalho de iniciação artística com principal enfoque na integração dessas quatro áreas: artes visuais, dança, música e teatro.

Dois fatos foram determinantes para a construção pedagógica da escola e, em grande parte, responsáveis pelo pioneirismo de sua proposta que foi se configurando ao longo do tempo: a ausência de um diretor em seu primeiro ano de existência, tendo só o suporte de Maria Eliza Bologna, e a falta de um modelo de referência a se seguir. Assim, "coube aos profissionais contratados pensar e organizar o funcionamento da escola: número de alunos por classe, tempo de duração das aulas, critérios de seleção, horários, currículo, critérios para estruturação dos grupos" (OLIVEIRA, 2006, p. 51). Até hoje, a participação ativa de professores, pais e alunos é intensa e importante. Uma das formas de participação, estruturada há décadas, é a eleição do coordenador entre os pares de cada área artística. Assim, atualmente, na condução do dia a dia da escola, a direção conta com um grupo de cinco coordenadores, ${ }^{98}$ um assistente artístico e um assistente pedagógico, além dos funcionários da secretaria e da portaria.

\footnotetext{
${ }^{97}$ Informação fornecida por Fonterrada em São Paulo, em 2013.

${ }^{98}$ Por ter um grande número de professores, a área de música tem dois coordenadores ao invés de um.
} 
Ao longo de seus 34 anos, a EMIA contou com várias direções que contribuíram para a construção de sua história, a saber: Ana Angélica Albano, Cléa Galhano, Ana Cristina Araújo Petersen, Yara Borges Caznók, Jean Pierre Kaletrianos, Miriam de Oliveira Mazzei, Thaia Perez e Márcia Soares Andrade.

Iniciamos o ano de 2014 com uma nova diretora, Andrea Fraga, ex-professora de dança da escola, eleita pelos professores pela primeira vez na história da EMIA. O lema dessa nova direção é "A EMIA somos nós”, carro-chefe de uma proposta de gestão democrática.

A partir de dados de 2014, a EMIA oferece em torno de 1.760 vagas para 972 alunos, ex-alunos e pessoas da comunidade local, distribuídos entre o curso regular e diversos cursos optativos e oficinas.

Os cursos regulares são oferecidos nas quatro áreas citadas, buscando sempre integrá-las, e se organizam de acordo com a faixa etária:

- 5 e 6 anos - duas horas de aula, uma vez por semana, com dois professores de linguagens artísticas diferentes na sala.

- 7 e 8 anos - três horas de aula, uma vez por semana, com dois professores de linguagens artísticas diferentes na sala.

- 9 e 10 anos - quatro horas de aula, uma vez por semana, com um professor de cada área, concomitantemente, permitindo a integração total dessas linguagens.

- 11 e 12 anos - três horas de aula, uma vez por semana, com um ou dois professores da linguagem artística escolhida pelo aluno.

Os cursos optativos são oferecidos paralelamente ao curso regular, e oferecem ao aluno a oportunidade de aprofundar seu conhecimento em uma das áreas, frequentando aulas específicas de artes visuais, dança, música ou teatro, em horário diferente do curso regular.

As aulas de instrumento musical fazem parte dos cursos optativos, mas, devido ao grande número de inscritos, há uma seleção a partir de dois critérios: tempo de EMIA e idade mínima para cada instrumento. Os cursos oferecidos são de bateria, cavaquinho, cordas coletivas, flauta doce, flauta transversal, guitarra, percussão, piano, violão, violino e violoncelo.

Há também as oficinas, oferecidas para alunos, ex-alunos e para a comunidade, que não fazem parte do eixo dos cursos regulares e têm como objetivo ampliar, diversificar e 
aprofundar conteúdos do currículo básico. Os temas derivam de projetos e pesquisas pessoais dos professores, e os alunos são classificados por ordem de inscrição.

É nesse contexto educativo que acontecem as aulas de piano. Selecionei composições de três alunos meus para serem objeto de estudo desta dissertação.

Começo pela apresentação de cada aluno, a descrição de suas composições e as reflexões pedagógico-musicais suscitadas, a saber:

1. Beatriz - livre improvisação e "Música sem título"

2. Laura - "Mistério"

3. Arthur - "O gigante" e "Ideia musical"

Neste capítulo, faço um relato reflexivo das experiências selecionadas, construído a partir de questionamentos e inquietações pedagógicas em relação ao ensino tradicional de piano que emergiram do contato com as ideias e as ações das crianças diante da música e especialmente do piano. A essas reflexões, somo referências teóricas, algumas já apresentadas nos capítulos anteriores, que embasam o pensamento exposto a seguir.

\section{2 "Música sem título"}

A primeira composição apresentada é "Música sem título", de Beatriz. Começo descrevendo a exploração sonora do teclado e do mecanismo interno do piano, seguida da livre improvisação, etapas que antecederam a composição propriamente dita. Para fundamentar essas duas práticas, exponho algumas referências teóricas. Por último, o foco é a análise da construção musical da composição e as reflexões pedagógico-musicais sobre esse processo criativo. Essas etapas foram gravadas em vídeo, com exceção da pesquisa sonora.

\section{Apresentando Beatriz}

Beatriz é aluna da EMIA desde 2008, quando tinha 5 anos de idade. Até 2013, frequentou aulas em grupo com linguagens integradas, parte do currículo obrigatório da escola, cursos optativos de teatro e coral, e é minha aluna de piano desde 2011. Em 2014, no 
currículo obrigatório, Beatriz optou pelo curso de teatro e continua a frequentar o coral e as aulas de piano.

Beatriz é uma criança alegre, demonstra gostar muito de música e, em especial, das aulas de piano. Tem uma postura bastante criativa e mostra-se muito envolvida nos momentos de criação e de tirar melodias de ouvido. Em contrapartida, mostrou-se resistente a aprender músicas por meio da partitura, mas essa postura foi se dissolvendo ao longo do ano. Não tem piano em casa e estuda na escola.

\section{Explorando o piano}

Anexo a este texto, apresento um vídeo com recortes das aulas de Beatriz. No primeiro recorte $(7 s-4 \min 48 s)$, está registrada uma livre improvisação na parte interna do piano, mais precisamente nas cordas, no segundo $(4 \min 49 \mathrm{~s}-8 \min 30 \mathrm{~s})$, o processo de elaboração de sua composição, a partir da experiência anterior, e, no terceiro recorte $(8 \min 31 \mathrm{~s}$ - 9min50s), a execução da própria composição, denominada por ela de "Música sem título".

Descrevo algumas atividades de exploração do teclado do piano e de seu mecanismo interno, realizadas nas primeiras aulas, e algumas referências teóricas. Apesar de essa etapa não estar gravada em vídeo, considerei importante incluí-la, pois as atividades de pesquisa sonora foram disparadoras do processo de criação de Beatriz.

O conhecimento tanto externo quanto interno do instrumento e a pesquisa de suas diversas possibilidades sonoras constituíram conteúdo de muitas aulas de Beatriz, principalmente nos primeiros meses de estudo. Essas explorações consistiram, basicamente, em: contar as teclas brancas e pretas; observar diferenças de comprimento e largura entre as teclas; sentir a vibração das cordas e da madeira quando o som é produzido; observar o funcionamento do mecanismo interno do piano; perceber a relação entre teclas, martelos, cordas e abafadores; constatar diferenças de espessura e de material entre as cordas e sua relação com a altura do som; apertar os pedais e ouvir as diferenças de sonoridade que eles provocam; enfim, manusear e explorar o piano em sua totalidade.

Às ações descritas acima, juntamos - aluna e professora - diferentes formas de produção sonora - raspar, percutir, dedilhar - e diferentes materiais: baquetas de feltro, madeira e borracha, moedas, bambu, copos de vidro e papeis entre as cordas e o martelo. 
A ideia era experimentar muitas possibilidades sonoras a partir da seguinte proposta: "vamos tirar a roupa do piano". 99 Desmontar o piano, deixando todo seu mecanismo à vista, estimulou a curiosidade de Beatriz e motivou essa exploração, embora a vivacidade e a curiosidade já sejam marcas de sua personalidade.

Após décadas lecionando piano para iniciantes, pude observar que, talvez por seu grande porte, o piano pode tanto encantar como assustar, atrair ou intimidar as crianças. Ele exerce um fascínio, mas também rapidamente pode frustrar, o que justifica a necessidade de buscar diferentes formas de interagir com o instrumento, construindo uma relação de intimidade. Essa intimidade com o instrumento é necessária para que o instrumentista faça dele um verdadeiro meio para sua expressão musical, uma ferramenta com a qual ele possa talhar a música. Assim, o músico não só deve conhecer o mecanismo da ferramenta, mas, como um bom ferreiro, por meio de contato diário e íntimo, deve transformá-la na extensão de sua mão e de seu pensamento.

Campos (2000, p. 75-76) refere-se ao instrumentista como artesão da música e afirma que só a experiência da relação estreita entre ele e o seu instrumento pode levá-lo à aprendizagem e ao conhecimento musical. Considero imprescindível criar espaços para que se construa, pouco a pouco, essa relação estreita e íntima do aluno iniciante com o piano.

As propostas de exploração do instrumento estimulam alunos de qualquer faixa etária, mas em especial as crianças, pois a curiosidade, o impulso de desmontar para saber como funciona, é característica comum a quase todas elas. Numa aula de musicalização, enquanto explorávamos o teclado do piano, um aluno de 5 anos disse: "O som sai que nem uma mágica". ${ }^{100}$ Sem dúvida, não é comum vermos suas cordas vibrarem. Apertamos as teclas e ouvimos o som que "não sai da tecla, não... ah! É lá de dentro!", concluiu o aluno, surpreso e encantado. As descobertas e o encantamento das crianças já justificariam a proposição de atividades de exploração sonora do instrumento, mas esse tipo de proposta também pode se transformar num rico trabalho de percepção e criação musical.

\footnotetext{
${ }^{99}$ A expressão "tirar a roupa de piano" faz parte do meu cotidiano com as crianças desde que trabalhei na Teca Oficina de Música, onde essa era uma expressão muito usada.

${ }^{100}$ Assim como outras citadas mais à frente, essa frase foi registrada em meus diários de aula da EMIA.
} 
Gainza (2002, p. 45, tradução nossa) nos ensina que “o ouvido é a porta de entrada, o testemunho e o controle da música que se absorve". ${ }^{101}$ Décadas atrás, Paynter (1972, p. 11, tradução nossa) também apontava o ouvir e a experimentação como pilares da educação musical: "Seja qual for o programa curricular, nós podemos estimular experiências com sons. A primeira tarefa do professor é a de abrir os ouvidos de seus alunos". ${ }^{102}$

Dessa forma, o objetivo dos momentos de pesquisa, descoberta e aproximação do piano realizados com Beatriz foi desenvolver sua percepção auditiva, propiciar a criação de um repertório sonoro amplo e possibilitar uma relação de intimidade com o instrumento.

Outro aspecto relevante das explorações sonoras como disparadoras de processos de criação é a possível aproximação com a música erudita da segunda metade do século XX. Como características principais dessa produção musical, podem-se citar a ênfase na pesquisa de novas fontes sonoras e de novas formas de produção do som em instrumentos convencionais e não convencionais, a valorização do timbre e a imprecisão de alturas e durações como recurso estético.

Paynter (1972, p. 12-13) apresenta como necessária uma educação musical que parta da experimentação e da criação e como de fundamental importância a conexão do pensamento pedagógico-musical com a produção artística, em especial a contemporânea (no seu caso, a do século XX). Segundo o autor, os educadores devem conhecer e apreciar os acontecimentos e as descobertas de seu tempo, levando-os para sala de aula, pois assim estarão capacitando os alunos a compreender o que os artistas contemporâneos têm a dizer. "Hoje, os compositores estão explorando novas técnicas de produção sonora, descobrindo novas gamas de possibilidades expressivas. Nós devemos possibilitar que nossos alunos tenham os mesmos fundamentos em suas experimentações"103 (PAYNTER, 1972, p. 12, tradução nossa).

Alguns meses depois das explorações sonoras, a audição de peças musicais do repertório citado por Paynter, ${ }^{104}$ assim como a introdução de peças do volume I do Játékok de

\footnotetext{
101 "El oído es la puerta de entrada e el testigo y control de la música que se absorve. Por eso, volverlo sensible, sutil, inteligente, creativo es la mejor garantía de una buena educación musical” (GAINZA, 2002, p. 45).

102 "Whatever the time-table situation we can begin to encourage experiment with sounds. The teacher's first task is to open his pupils'ears" (PAYNTER, 1972, p. 11).

103 "Composers today are exploring new sounded-making techniques, discovering new ranges of expressive possibility. We shall find that our pupils cover some of the same ground in their experiments" (Paynter, 1972, p. 12).

${ }^{104}$ Esse repertório se refere à música de vanguarda da segunda metade do século XX, quando emergiram diversas tendências musicais, tendo à frente nomes como Olivier Messiaen (1908-1992), Edgar Varèse (1883-
} 
Kurtág, ${ }^{105}$ passou a fazer parte das aulas de Beatriz. No entanto, como a análise dessas atividades não faz parte do objetivo desta pesquisa, não as descreveremos, mas as citamos apenas para salientar mais uma possibilidade de trabalho musical que pode ser disparada pelas atividades de pesquisa sonora no instrumento.

\section{Improvisando livremente}

A seguir, faço uma reflexão sobre a livre improvisação de Beatriz, registrada no vídeo $(7 s-4 \min 48 s)$, anexo a este texto. Depois da experimentação das possibilidades sonoras do piano aberto, desenvolvida em diversas aulas e já descrita anteriormente, realizamos a quatro mãos, aluna e professora, uma prática de improvisação diferente da que estávamos habituadas: uma livre improvisação. Cabe, aqui, contextualizar essa proposta.

Em décadas de prática docente de musicalização e piano, as improvisações idiomáticas sempre fizeram parte do trabalho desenvolvido com os alunos, que além das improvisações é constituído por composições, melodias para tirar de ouvido, peças aprendidas por imitação, leitura de peças em escrita tradicional e também com notação não convencional, noções de harmonia prática, peças com melodia e baixo, peças com melodia e cifras, transposições, exercícios técnicos e escalas. O repertório é composto por músicas tradicionais brasileiras e de outros países, eruditas, populares brasileiras e pop americano (que compõem o repertório de escuta da grande maioria dos alunos, principalmente os que têm entre 10 e 12 anos). A saber, uso a definição de improvisação idiomática concebida pelo guitarrista inglês e livre improvisador Derek Bailey: "Improvisação idiomática, como é amplamente utilizada, referese, principalmente, à expressão de um idioma - como jazz, flamenco ou barroco - e tem sua identidade e motivação dentro do próprio idioma"106 (BAILEY, 1993, p. xi, tradução nossa).

É importante destacar que a diversidade de procedimentos de aprendizagem e de repertório é princípio norteador do trabalho realizado com os alunos de piano que compõem o foco dessa pesquisa. Entendo que o estudo de um instrumento não deva se limitar à

1965), Pierre Schaeffer (1910-1995), Iánnis Xenákis (1922-2001), Pierre Boulez (1925-) e Karlheinz Stockhausen (1928-2007), entre outros.

${ }^{105}$ György Kurtág é um compositor húngaro que escreveu uma coleção de oito volumes com peças para piano (Játékok), com uma escrita contemporânea. Ver capítulo 1.

106 "Idiomatic improvisation, much the most widely used, is mainly concerned with the expression of an idiom such as jazz, flamenco or baroque - and takes its identity and motivation from that idiom" (BAILEY, 1993, p. xi). 
interpretação musical restrita à leitura de partituras. A experiência em sala de aula e o estudo de abordagens de educação musical mais contemporâneas (BRITO, 2003; 2004; 2007; CAMPOS, 2000; GAINZA, 2002; 2007; 2013; KOELLREUTTER, 1997; SWANWICK, 1988; 1994; 2003, entre outros) me levaram a incorporar ao trabalho com as crianças possibilidades que abarcam criação e interpretação, assim como diferentes notações musicais.

Apesar de trabalhar diferentes proposições em minhas aulas, só a partir de 2012 me motivei a propor a prática da livre improvisação para os alunos. Na verdade, muitas das explorações sonoras no piano aberto resultavam num fazer musical próximo do que se poderia denominar livre improvisação. No entanto, ainda não havia me apropriado suficientemente de tal prática para propô-la regularmente aos alunos. Ao lado da prática pessoal, venho construindo um corpo de referências para a inclusão dessa prática a partir do contato com a obra de alguns músicos e compositores ${ }^{107}$ como Cecil Taylor, Cesar Villavicencio, Derek Bailey, Fernando Iazzetta, John Cage, John Coltrane, Karlheinz Stockhausen, Ornette Coleman, Rogério Costa, Terry Riley e Vinko Globokar.

Embora esse tipo de improvisação ainda não seja habitual nas aulas de Beatriz, ela recebeu todas as propostas sem resistência, envolvendo-se muito e várias vezes tomando a iniciativa.

A gravação em vídeo presente nesta pesquisa foi a primeira experiência de Beatriz com a livre improvisação. A proposta era a seguinte: "Vamos inventar uma música com apenas duas regras: não pode ser muito comprida e não vamos combinar nada antes de tocá-la. Temos que ouvir uma à outra e perceber como tocar, sem combinarmos um começo, um meio ou um fim". Ficou claro também que tínhamos a nossa disposição a harpa do piano e toda sua estrutura, inclusive o teclado, o qual não foi utilizado. Não havíamos combinado que só tocaríamos nas cordas, mas arrisco a afirmar que Beatriz não tocou no teclado porque a sonoridade das cordas exercera sobre ela um grande fascínio nos momentos de pesquisa sonora das aulas anteriores.

Beatriz nem esperou pelo fim da apresentação da proposta e já começou a percutir a estrutura de metal da harpa do piano. Nessa hora, salientei a importância do silêncio antes de

\footnotetext{
107 Tive um contato mais aprofundado com a livre improvisação no primeiro semestre de 2012, quando cursei a disciplina Nos Territórios da Livre Improvisação", ministrada pelo prof. dr. Rogério Luiz M. Costa, na grade curricular do Programa de Pós-graduação em Música da Escola de Comunicação e Artes da Universidade de São Paulo (ECA-USP).
} 
começar qualquer música, pois ele prepara o som, que dele emerge: "Na música, de fato, o que soa não é importante, quando não se levar em consideração aquilo que não soa. É o som que revela e valoriza o silêncio, e é o silêncio que revela e valoriza o som" (KOELLREUTTER, 1997i, p. 105, grifos do original). Ao assistir o vídeo, nota-se a ansiedade de Beatriz para tocar e, mesmo depois da minha fala sobre o valor do silêncio, ela me olha e indica com a mão que eu comece, mas, como tal não acontece, ela toma a iniciativa. É difícil compreender a importância do silêncio na música, tanto na preparação como no próprio discurso musical. Essa consciência deve ser construída aula a aula, ressaltando-se a importância do silêncio em várias ocasiões para que a criança a perceba e compreenda, pois, em geral, a vontade de tocar é sempre maior. No vídeo, também fica evidente que o silêncio não foi utilizado nem no início, nem durante a música. No contexto da livre improvisação, faz-se bastante evidente a dificuldade de buscar o silêncio, o que pude observar não só na atuação de Beatriz mas na minha própria, como pianista e professora.

Após rever o vídeo diversas vezes, considero relevante dirigir o foco da reflexão para minha atuação como professora. Eu poderia ter enfatizado mais a importância do silêncio para Beatriz? Algumas possibilidades: além de chamar sua atenção para isso, como o fiz, poderia ter ressaltado essa questão quando assistimos à gravação logo após a performance; eu poderia ter inserido momentos de silêncio durante a improvisação, evidenciando as ideias sonoras, o que talvez tivesse sido mais eficiente, pois ela poderia perceber o valor do silêncio a partir do próprio discurso musical. Por outro lado, analisar o vídeo e perceber esse fato me motivou a propor improvisações livres com o propósito específico de valorizar o silêncio.

A constante avaliação dos processos de aula e a autoavaliação são recursos preciosos na busca de uma maneira de ensinar música ligada a uma educação menos autoritária e mais participativa. Uma postura contemporânea e criativa exige do professor uma escuta atenta, uma observação perspicaz durante toda aula e uma constante reflexão. Em diversos textos, Koellreutter enfatiza a importância de o professor reaprender a lecionar e aponta um novo professor que não é um "semideus sabe-tudo, alheio a todos os problemas" mas "o guia do aluno, o amigo, o conselheiro" (KOELLREUTTER, 1997a, p. 27). Sem dar a resposta ou fornecer as soluções de forma mecânica, o professor deve apresentar problemas e as soluções devem resultar de um trabalho comum do qual todos participem, fazendo desaparecer o “dualismo tradicional professor-aluno" (KOELLREUTTER, 1997f, p. 53). 
Não é fácil para nós, educadores que vivenciamos a escola da cartilha e das respostas decoradas, na qual o professor ensinava e o aluno aprendia, ter essa postura como professores, mas é necessário que nos disponibilizemos a construí-la. O pensamento de Koellreutter pode ser uma inspiração na construção desse novo modelo de professor.

A incorporação de propostas de improvisação livre nas aulas de piano também pretendia exercitar essa nova relação professor-aluno, pois essa prática exige uma escuta musical atenta e a participação igualitária entre os improvisadores, que constroem o discurso musical juntos. É importante ressaltar que, especialmente nas aulas de Beatriz, a prática da livre improvisação vêm disparando, gradualmente, um processo de apuramento de sua escuta. Em relação à escuta, Cesar Villavicencio, Fernando Iazzetta e Rogério Luiz M. Costa, músicos e praticantes da livre improvisação, desenvolvem em seu artigo "Fundamentos técnicos e conceituais da livre improvisação" algumas argumentações relevantes:

Para nós, a improvisação livre se desenvolve melhor em um ambiente direcionado para a ideia de escuta reduzida [...] Este tipo de escuta é direcionado para os atributos do som em si, ou, segundo Schaeffer, ao objeto sonoro [...] A escuta descondicionada buscada pelo exercício da escuta reduzida faz com que a nossa audição se torne permeável ao que é imprevisível, desconhecido e ainda não estruturado. Ao eliminar as referências contextuais dos sons, poderíamos produzir uma escuta imersiva, focada nas qualidades intrínsecas que o som, em sua condição de fenômeno acústico, provoca em nossa percepção. Essa ênfase na percepção do som enquanto objeto sonoro, quando aplicada ao processo de criação musical, pode reverter num dinamismo na direção da exploração das possibilidades de combinações sonoras, de variedade de articulações, e de modulação tímbricas. Na improvisação livre, essa busca vem associada à exploração de combinações instrumentais, de pesquisa de novos timbres como resultado do uso de técnicas estendidas, de emprego de ritmos complexos, da adoção de processos indeterminados. Dessa forma, poderíamos imaginar que a prática da improvisação livre, ou improvisação contemporânea como preferem alguns autores, se apoia, como diria John Cage, no uso dos sons pensados simplesmente como sons - sons que ainda não adquiriram qualquer tipo de representação ou de contexto (VILLAVICENCIO; IAZZETTA; COSTA, [s.d.]).

Embora tais considerações se refiram à prática profissional e, consequentemente, a um outro nível de complexidade e envolvimento com a livre improvisação, acredito que uma situação similar possa ser compartilhada em ambientes de iniciação ao instrumento. É possível identificar, tanto nas explorações sonoras descritas anteriormente como na livre improvisação de Beatriz, que sua relação com a escuta se aproxima de uma escuta de imersão, focada nas qualidades do som, como apontam os autores. Outro aspecto levantado por eles e que pudemos identificar no processo dessa aluna se relaciona com a interação dos músicos no 
momento da improvisação. Os autores afirmam que "na improvisação livre, a estruturação formal é resultado de um processo coletivo e interativo" (VILLAVICENCIO; IAZZETTA; COSTA, [s.d.]), enfatizando a importância da interação entre os músicos para o produto sonoro-musical. Ainda considerando as devidas diferenças entre a improvisação de músicos profissionais e a de Beatriz, notamos na livre improvisação gravada uma grande interação entre aluna e professora, determinante para o resultado sonoro final.

A seguir, descrevo a livre improvisação em relação à construção musical com o objetivo de entender mais a fundo o desenvolvimento do pensamento musical de Beatriz.

\section{Descrição da livre improvisação}

\section{Primeiro momento (1min - 1min18s)}

O primeiro momento dessa improvisação acontece em um tempo métrico e se desenvolve sobre um motivo rítmico criado por Beatriz, apresentado logo no início da música. Num espaço de jogo e diálogo entre aluna e professora, alternam-se quatro frases, o motivo rítmico da primeira é mantido na segunda e na terceira, com variações de timbre, articulação e alturas, e, na última frase, além dessas, há variação rítmica.

A primeira frase é tocada na estrutura de metal da harpa do piano, na segunda frase, $o$ mesmo motivo é tocado ainda na estrutura de metal, mas o último pulso é realizado como um rápido glissando descendente nas cordas. Beatriz responde variando timbre e altura, tocando com uma baqueta nas cordas o mesmo motivo rítmico, sendo seguida por mim, tocando uma pequena ampliação do motivo, nas cordas com baqueta, acrescentando uma anacruse e finalizando com uma espécie de rulo.

Motivo rítmico:

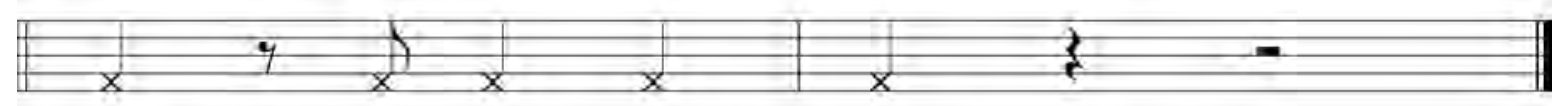




\section{Segundo momento (1min19s - 4min48s)}

Esse momento, que ocupa dois terços da música, apresenta diversas texturas ${ }^{108} \mathrm{com}$ densidades e articulações diferentes, passando por pequenos momentos métricos e outros não métricos.

Começa com um tempo não métrico, em que Beatriz explora a sonoridade das cordas rapidamente, seguida por mim, com um glissando descendente na região aguda, ainda em um diálogo mas não mais tão apegadas à forma pergunta-resposta como no primeiro momento.

Dessa primeira textura $(1 \min 19 \mathrm{~s}$ - $1 \min 32 \mathrm{~s})$, rapidamente passamos a uma mais pontilhada e, em seguida, mesclada com a exploração de possíveis articulações e gestos, como raspar, deslizar, percutir nas cordas, crescendo em densidade e intensidade, por volta de meio minuto (1min32s - 2min02s). A intensidade vai se diluindo, passando por um breve momento rítmico, com alternância de pulsos percutidos nas cordas $(2 \min 02 \mathrm{~s}-2 \min 36 \mathrm{~s})$ e voltando ao tempo não métrico e à exploração de gestos e modos diferentes de produzir sons nas cordas, por aproximadamente um minuto $(2 \min 36 \mathrm{~s}-3 \min 34 \mathrm{~s})$. Esse momento permanece por algum tempo, crescendo e decrescendo até um prolongamento da ressonância de um dos gestos, cortado por um glissando ascendente e descendente bem rápido nas cordas bem agudas (3min34s - 3min40s). Seguem-se alguns segundos de indeterminação, com explorações e tentativas de diálogo com alternâncias de intensidade, terminando em sons diluídos e graves tocados por Beatriz nas cordas com baqueta (3min40s - 4min48s).

\section{Reflexões sobre a livre improvisação}

Analisando detalhadamente a improvisação livre, notei que o foco se concentrou na exploração sonora das possibilidades que as cordas do piano nos ofereciam e no espaço de jogo e diálogo entre aluna e professora. Procedimentos de imitação, contraste e complementaridade aparecem durante toda a improvisação. Depois do primeiro momento métrico, com motivo rítmico preciso, pode-se observar que passávamos por tempos não

\footnotetext{
${ }^{108}$ O termo textura usado neste texto segue a definição de Costa (2003, p. 105): “A textura produz uma sensação a partir de uma configuração e de um dinamismo entre os elementos presentes num determinado fluxo sonoro. É a escuta de um grande tecido sonoro em plena modulação/transformação. Não tem direcionalidade geral (apesar de ser, às vezes, povoado de figuras com suas pequenas direcionalidades locais) e é puro delineamento sonoro do tempo numa possível aproximação com as formulações de Olivier Messiaen. Na constituição de uma textura se somam e se entrelaçam de maneira complexa materiais diversos, figuras e gestos. Por isso, segundo Ferneyhough, através da textura complexa se atinge, ou se busca, a primeiridade, a sensação".
} 
métricos e métricos, texturas, gestos e figuras, ${ }^{109}$ numa sucessão de estados provisórios conduzidos pela pesquisa sonora em si, não por uma intenção de forma. A interação entre professora e aluna, mediada pela música, se construía tanto por uma como por outra, e fazer música em tempo real nos ocupava totalmente. Estávamos imersas, e Beatriz demonstrava esse envolvimento em suas expressões faciais. Uma certa ludicidade - experiência de jogo perpassava esse acontecimento musical, misto de explorações e formas sonoras fluindo no tempo. O texto do compositor francês e criador da música concreta Pierre Schaeffer (19101995) de certa forma ilustra a postura lúdica que experimentamos nessa primeira improvisação livre de Beatriz e reforça a ideia de que a música estava presente:

Com efeito, esse menino experimenta os seus sons uns após os outros, e o problema que ele coloca é menos o da identificação do que o do estilo de fabricação. Por outro lado, a sua intenção é visivelmente "música". Se o resultado não parecer musical aos seus ouvintes exasperados, não se poderia negar ao autor uma intenção estética, ou pelo menos uma atividade artística (SCHAEFFER, 1993, p. 283-284).

\section{Compondo... "Música sem título"}

A composição de Beatriz foi elaborada a partir da exploração sonora das cordas do piano e de uma escuta atenta das possibilidades dessa experimentação. A reflexão a seguir inclui desde o processo de elaboração da música (4min50s - 8min30s) até sua execução final $(8 \min 31 \mathrm{~s}-9 \min 50 \mathrm{~s})$.

"Música sem título" resultou da combinação da experimentação de sonoridades diversas e da imaginação musical de Beatriz. Ouso dizer que, guardadas as devidas proporções, o processo de composição foi bastante similar ao vivenciado por artistas, como o descrito no trecho a seguir:

Mas nós frequentemente esquecemos que artistas de todo tipo (mesmo o profissional altamente avançado) começam experimentando ideias e materiais. Eles não trabalham com "regras": eles trabalham com a imaginação e experimentação, moldam seus materiais às ideias que eles tinham imaginado (PAYNTER, 1972, p. 10).

\footnotetext{
${ }^{109}$ Os termos gesto e figura também foram usados segundo as definições de Costa (2003, p. 101-103): "gesto é aquele que tem origem num sistema de referência musical utilizado (idioma) [...]. Pode ser também aquele ligado à movimentação do corpo por analogia ou abstração [...]. A figura é um material 'plástico', geralmente de caráter rítmico-melódico, conveniente, por exemplo, para o trabalho de variação e desenvolvimento temático [...]”".
} 
É certo que Beatriz não partiu de uma ideia preconcebida, como acontece muitas vezes com os compositores, mas, a partir das pesquisas sonoras das aulas anteriores e das ideias sonoro-musicais que surgiram na improvisação livre, pode-se perceber claramente nos registros de vídeo que ela escolhe determinados timbres e alturas, organiza-os e busca aqueles que deseja, revelando uma intenção musical. De acordo com o que já foi argumentado sobre o uso do termo composição para as invenções das crianças, considero que, referendando-me em França e Swanwick (2002, p. 11), "Música sem título" é produto de um processo de “[...] articulação e comunicação do seu pensamento em formas sonoras". Portanto, uma composição simples, com ideias expostas sinteticamente, porém uma composição.

Revendo o vídeo várias vezes, observei determinadas escutas e escolhas de Beatriz durante o processo de elaboração da música. Em alguns momentos, sua imersão na escuta do som em si, sem nenhuma associação, focada no objeto sonoro, pareceu-me se aproximar do conceito de escuta reduzida criado por Pierre Schaeffer (1910-1995) em seu conhecido Traité des objets musicaux. Antes de enfocar as escutas e as escolhas de Beatriz, descrevo brevemente esse conceito e outros relacionados, por ser de interesse para o trabalho. ${ }^{110}$

De acordo com Schaeffer (1966), o processo auditivo pode ser decomposto em quatro escutas: oü̈r, écouter, entendre e comprendre. Apesar de diferentes, todas se relacionam e somam, formando um todo. É importante destacar que Schaeffer não apresenta esses modos de escuta como lineares e sequenciais, mas sim como num circuito que segue em vários sentidos, e ora temos percepções mais subjetivas, ora mais objetivas, ressaltando aspectos mais abstratos ou mais concretos.

A primeira escuta apresentada, oürr, é uma escuta passiva, isto é, ouvimos o que acontece sonoramente em nosso entorno, pois estamos imersos nele, não importando o que estamos fazendo ou o que nos interessa naquele momento. No entanto, mesmo sendo uma escuta passiva, nós reagimos a ela, seja só por um reflexo condicionado ou uma memória daqueles sons. Já écouter refere-se a uma atitude ativa do ouvinte, na qual ele associa, espontaneamente, o som à fonte sonora que o produziu. Segundo Schaeffer, essa escuta está

\footnotetext{
${ }^{110}$ Ressaltamos que os diversos conceitos apresentados em Tratado dos objetos musicais, de Schaeffer, são bastante complexos e exigem uma leitura cuidadosa e aprofundada. Como esse assunto não é objetivo deste trabalho, apesar de servir como referência, apresento sinteticamente os conceitos em torno da escuta reduzida, mas o leitor interessado pode se remeter diretamente à fonte (SCHAEFFER, 1966), como também a outros trabalhos que discutem o assunto, como Brito (2007), Chion (2014), Costa (2003), Reyner (2011) e Santos (2006), entre outros.
} 
ligada à causa que originou o som e o ouvinte percebe o som como índice do evento sonoro (SCHAEFFER, 1966, p. 114-115).

Segundo Santos (2006, p. 59), entendre está relacionado a "uma determinada intenção, encontrando-se diretamente ligada às preferências e experiências do ouvinte e selecionando aquilo que é de seu interesse particular". De acordo com a mesma autora, Schaeffer associa esse modo de escuta aos dois anteriores: oür-entendre e écouter-entendre. $\mathrm{Na}$ primeira associação, o ouvinte seleciona o som que lhe é mais "atrativo, interessante ou significativo, mas ignorando qualquer mensagem que ele possa conter", mudando de foco entre um som e outro de acordo com o que se vai desenvolvendo sonoramente em seu entorno. Já na segunda, retira do entorno sonoro no qual está imerso o som que irá escutar, aprofundando essa escuta, percebendo suas nuanças, no que Schaeffer denomina "escuta qualificada”.

O último modo de escuta definido por Schaeffer, comprendre, realiza-se em processos de abstração, comparação e dedução de diversas informações em busca de um significado específico, partindo de "percepções qualificadas, que fazem referência a determinados conjuntos de conhecimento, nesta etapa, o ouvinte alcança outro tipo de significação, mais abstrata: um signo" (SANTOS, 2006, p. 59-60).

Schaeffer (1966, p. 120) define duas tendências de escuta, subdividindo cada uma em duas atitudes: escuta natural e escuta cultural, ao lado de escuta banal e escuta prática ou especializada. A escuta natural está presente em todos nós, seres humanos, e se relaciona à percepção do som para sinalizar um evento, um acontecimento, isto é, um indício. Já a escuta cultural está relacionada a aspectos mais abstratos, se referindo "à mensagem, aos significados e 'valores' dos quais o som é portador""111 (SCHAEFFER, 1966, p. 121), aos quais estamos condicionados pelo ambiente cultural no qual vivemos. $\mathrm{O}$ outro par de escutas (banal e especializada) considera o som como índice e dentro de um contexto cultural, mas há diferenças em relação à intenção de escuta. A banal é mais superficial ${ }^{112}$ e a especializada, mais direcionada, mais focada (SCHAEFFER, 1966, p. 122).

Segundo Schaeffer (1966, p. 155), direcionamos nossa escuta de duas maneiras: para a origem do som ou para os significados que denotamos a ele, relacionados a determinada

\footnotetext{
111 “[...] au message, à la signification, aux valeurs dont le son est porteur” (SCHAEFFER, 1966, p. 121).

112 Santos (2006, p. 61) ressalta que não existe julgamento de valor em relação à escuta banal, da qual o compositor aponta vantagens, como a de estar mais aberto a diversas direções.
} 
linguagem sonora. Segundo Santos, a análise de Schaeffer questiona esse dualismo, propondo um outro tipo de escuta. Ela afirma que ele busca "perceber aquilo que seria a "unidade original' daquelas percepções habitualmente dissociadas, o 'objeto sonoro"” (SANTOS, 2006, p. 61).

Segundo Reyner (2011, p. 103), o que caracteriza essa escuta apontada por Santos (2006), a escuta reduzida de Schaeffer, ${ }^{113}$ é "uma atitude de escuta, uma perversão das tendências auditivas apresentadas acima. É um direcionamento da escuta para as funções oü̈r e entendre". Nesse sentido, a escuta reduzida busca o não condicionamento das escutas que se operam espontaneamente, e segue em direção ao som em si, independente dos índices que pode revelar ou seu significado. De acordo com o próprio Schaeffer, na escuta reduzida "a intenção se dirige ao próprio som [...] esquecendo-se dos índices e valores em benefício de uma percepção global, de conjunto, rara, porém incontestável porque, ao haver descuidado voluntariamente da procedência do som, percebe-se o objeto sonoro" (SCHAEFFER, 1966, p. 89, tradução nossa). Para ele, a definição de objeto sonoro é "o próprio som, considerado em sua natureza sonora, e não como objeto material (qualquer instrumento dispositivo) do qual provém"114 (SCHAEFFER, 1966, 23, tradução nossa). Esses dois conceitos, objeto sonoro e escuta reduzida, foram fundamentais para a criação da música concreta, denominada assim pelo próprio Schaeffer, em 1948.

Por fim, é interessante lembrar que o pensamento de Pierre Schaeffer foi construído em oposição ao estruturalismo do século $\mathrm{XX}$, cujos compositores valorizavam ao extremo a estruturação musical, anterior mesmo à experiência. Schaeffer cria a música concreta a partir da escuta e do fazer musical, isto é, "propõe uma mudança de foco da dupla fazer/ouvir para um ouvir/fazer" (MARINI, 2009, p. 1).

\footnotetext{
${ }^{113}$ Esse conceito não é definido direta e textualmente em Traité des objets musicaux, sendo tratado em algumas páginas, em meio a outros conceitos. Apresentá-lo como no original não seria pertinente ao objetivo desta dissertação, portanto, optei por buscar referências que já se debruçaram sobre as proposições de Schaeffer e que estão mais de acordo com as dimensões deste trabalho.

114 “[...] le son lui-méme, considèré dans su nature sonore, et non pas l'objet matériel (instrument ou dispositif quelconque) dont il provient" (SCHAEFFER, 1966, 23).
} 


\section{Escutas e escolhas de Beatriz}

Em diversos momentos da pesquisa sonora para a composição, pareceu-me que Beatriz estava escutando como se fosse pela primeira vez, sem associações a índices ou às fontes sonoras, mas com a atenção voltada totalmente ao som. Associo essa qualidade da escuta de Beatriz à escuta reduzida de Schaeffer. Descrevo, a seguir, alguns desses preciosos momentos.

Houve um momento em que realizei um gesto descendente bem rápido, escorregando uma baqueta de madeira entre duas cordas, produzindo um glissando que se prolongou por determinado tempo. Esse som chamou a atenção de Beatriz, que parou de tocar, olhou para mim e mexeu rapidamente a baqueta no ar, externando a sensação de vibração do som que escutava (5min16s - 5min22s). Sua expressão, por segundos, era de mergulho total naquele objeto sonoro. Logo em seguida, começou a percutir a baqueta de borracha onde as cordas estão presas aos pinos, provocando um som bastante agudo e seco ( $5 \mathrm{~min} 23 \mathrm{~s})$. Novamente, sua atenção estava completamente voltada para o som produzido. Seu olhar e seu sorriso revelavam seu total envolvimento com a escuta, como se só existisse o som navegando no espaço e no tempo.

Já tentando finalizar a música $(7 \min 17 \mathrm{~s}-8 \min 30 \mathrm{~s})$, Beatriz se lembrou de um som que havia feito anteriormente e de que gostara bastante. Procurou o exato lugar em que havia raspado a baqueta até encontrar o som desejado e, nesse momento (8min19s $-8 \min 23 \mathrm{~s})$, parou e ouviu atentamente. É interessante notar como Beatriz ficou imóvel por segundos, imersa na escuta. Essa unidade indivisível do som me fez recordar que, "para a música concreta, um som é um som (seja puro ou complexo), e ele é inseparável de sua situação no espectro sonoro. Na escala de sons, tudo é qualidade, nada mais é passível de ser sobreposto, divisível, transponível" (SCHAEFFER, 1950, p. $40^{115}$ apud REYNER, 2011, p. 88). É importante ressaltar que não estou afirmando que Beatriz tenha composto uma música concreta, apenas associando sua experiência ao modo de compor de um compositor de música concreta.

O estudo de Brito (2007) sobre o fazer musical das crianças confirma a associação feita acima, relacionando a música das crianças à estética do impreciso concebida por

\footnotetext{
${ }^{115}$ SCHAEFFER, P. Introduction à la musique concrète. Polyphonie - La musique mécanisée, Paris: Richard-Masse, v. 6, 1950.
} 
Koellreutter ${ }^{116}$ e ao comportamento de um músico concreto. Sem remeter-se a critérios de valor, a educadora musical afirma que a forma como as crianças fazem e pensam música, principalmente as da primeira infância, está muito mais próxima da imprecisão, "além das alturas e durações definidas", do que da precisão característica do "sistema musical tradicional ocidental" (BRITO, 2007, p. 81). Da mesma forma, a atitude do músico concreto que busca o som em si, sem seus índices e significados, encantando-se com o objeto sonoro, aproxima-se do modo musical da criança. Em suas palavras: "O jogo musical das crianças, nesta fase, costuma valorizar aspectos de ordem qualitativa, referentes à potência do sonoro, à sonoridade, à conquista do material” (BRITO, 2007, p. 83). Em outro texto, Brito deixa mais claras essas associações:

Analisando o fazer musical de crianças, cruzei a Estética relativista do impreciso e do paradoxal, proposta composicional apresentada por H.-J. Koellreutter, com as proposições acerca do jogo entre sonoridade e musicalidade apresentadas pelo compositor francês Pierre Schaeffer (19101995), em seu Tratado dos objetos musicais, publicado em 1966 (Schaeffer, 1988). Relacionando e aproximando as condutas musicais infantis de princípios estéticos do universo adulto, busquei contribuir no sentido de redimensionar as ideias de música, de modo geral, e os modos de escutar e de considerar as produções musicais das crianças, em particular (BRITO, 2009, p. 27).

Segundo François Delalande (1995), ${ }^{117}$ pesquisador musical francês, em seu livro La musique est un jeu d'enfant, a experiência musical infantil se aproxima da música contemporânea porque uma de suas principais características é o regresso às fontes. As crianças pequenas são músicos concretos, isto é, têm uma atitude diante do sonoro - de descobrir objetos, corpos sonoros - muito parecida com a de "um músico trancado em um estúdio para fazer uma gravação"118 (DELALANDE, 1995, p. 15, tradução nossa).

Embora Beatriz não seja uma criança pequena, ela criou sua música a partir de elementos próximos aos da música concreta e teve uma atitude bem parecida com a de um músico concreto, como afirmamos em parágrafos anteriores. Também é possível observar gestos, texturas e figuras em "Música sem título", elementos comuns no universo do fazer musical contemporâneo.

\footnotetext{
116 Segundo Brito (2007, p. 79), a estética do impreciso, como preceito estético de composição, refere-se a "planos em que ocorrências definidas são substituídas por tendências que sugerem, que delineiam, mas não determinam; mudanças que envolvem, especialmente, os parâmetros altura e duração, mas não apenas estes".

${ }^{117}$ Neste texto, usamos uma edição espanhola, La música es un juego de niños, editada em 1995, mas o original francês data de 1984 .

118 “[...] un músico encerrado en un estudio para hacer una grabación” (DELALANDE, 1995, p. 15).
} 
Enfim, uma observação atenta da performance de Beatriz revela a intensidade daquela experiência para ela. Suas escolhas foram regidas por suas escutas e, aos poucos, Beatriz foi ordenando sons diversos que foram ganhando um significado e tornando-se música.

\section{Descrição musical da composição de Beatriz}

Primeiramente, é importante relatar que minha participação em "Música sem título" foi requisitada desde o início por Beatriz. No vídeo, vê-se que seria difícil uma única pessoa executar algumas partes sozinha. Mas considero que o motivo maior dessa escolha foi a livre improvisação a quatro mãos feita logo antes. Espontaneamente, Beatriz transpôs essa ideia para sua composição. Não conversamos sobre isso, mas, quando propus que compusesse uma música a partir da pesquisa sonora anterior e da livre improvisação, ela imediatamente me incluiu na performance, assumindo o controle da situação, conduzindo e determinando o que queria que eu fizesse.

A seguir, descrevo a forma da composição com os elementos de cada um dos momentos musicais. Escolhi denominá-los momentos e não partes por considerar o termo mais apropriado, já que se trata mais de momentos variados de um único fluxo musical do que de partes estanques. Sendo assim, "Música sem título" apresenta três momentos (A, B e C).

\section{Momento A (8min34s - 8min45s)}

A música começa com a execução do seguinte motivo rítmico:

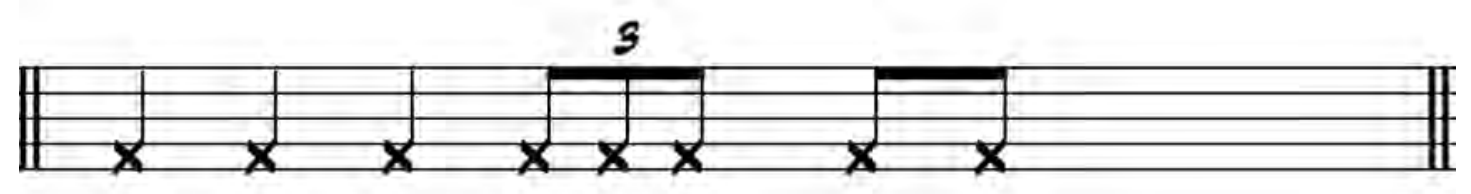

Beatriz toca esse motivo com percussão corporal (mãos nas pernas) uma única vez (8min34s - 8min36s) e, em seguida, ele é repetido na sustentação de ferro da harpa do piano, porém desmembrado em duas partes, sendo que a primeira é tocada pela professora e a segunda, por Beatriz (8min37s - 8min39s). 


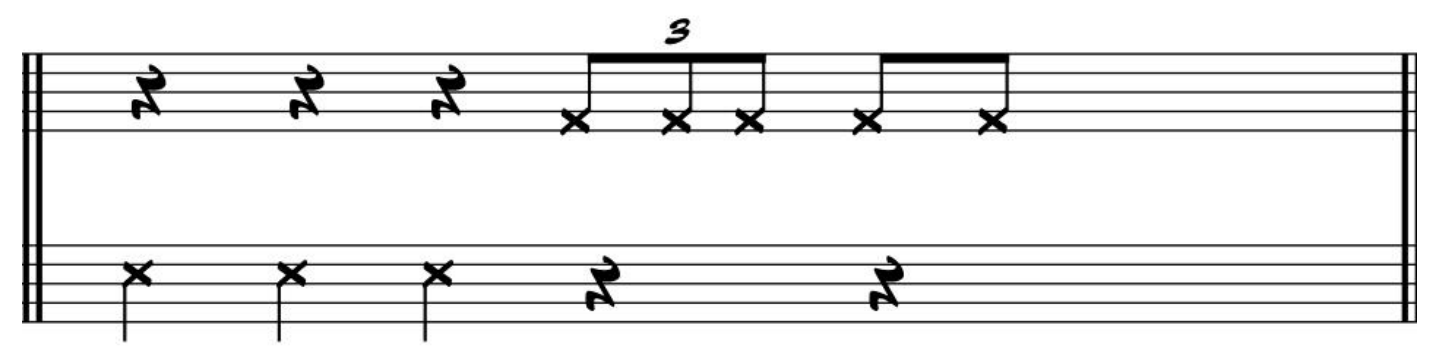

A terceira repetição do motivo $(8 \min 40 \mathrm{~s}-8 \min 42 \mathrm{~s})$ é tocada em uníssono pelas duas instrumentistas, e a quarta repetição $(8 \min 43 \mathrm{~s}-8 \min 45 \mathrm{~s})$ é tocada só pela professora, ambas as vezes na sustentação de ferro da harpa do piano.

Ponte $(8 \min 46 \mathrm{~s}$ - 8min59s): 8 pulsos tocados com baqueta de feltro na tábua harmônica do piano, seguidos de um rápido silêncio até o início do segundo momento.

\section{Momento B (9min - 9min15s)}

Inicia-se com uma marcação na subdivisão do pulso (tendo como referência o mesmo da ponte) no suporte de madeira dos pedais, feita pela professora. Rapidamente, depois de 2 pulsos, Beatriz acompanha em uníssono por mais alguns pulsos, e uma maior densidade de ritmos e velocidade faz-se sentir, culminando com um som produzido por um ataque com baqueta na região grave das cordas do piano, terminando o momento $\mathrm{B}$ e iniciando o momento $\mathrm{C}$.

\section{Momento C (9min15s - 9min50s)}

Esse momento é constituído por um diálogo entre aluna e professora, tocado com baquetas nas cordas, na mesma região grave do ataque final do momento B. Pode-se perceber um leve aumento de densidade e velocidade que termina num ataque preciso seguido de um raspar da baqueta de lã nas cordas, que Beatriz realiza com um movimento em espiral, apoiado pelo pedal 3C (9min30s - 9min38s). O efeito do pedal funciona como uma ligação para o final: 10 glissandos ascendentes na região aguda das cordas do piano, tocados por Beatriz com a parte de madeira da baqueta, terminando com um suave ataque com baquetas nas cordas, na região média, executado pela professora. 
Nesta reflexão, destaco a relação com o tempo na composição de Beatriz. Ela começa a música com um andamento e um motivo rítmico preciso. Já na ponte com o momento $\mathrm{B}$, os oito pulsos são mais lentos em relação ao momento A. No início do momento B, ouve-se uma subdivisão de um pulso mais rápido do que a ponte, mas não no mesmo andamento do momento A. Esse pulso subdividido vai se transformando rapidamente com a presença de um acelerando e o aumento de densidade de ritmos. A regularidade é retomada quando se inicia o momento $\mathrm{C}$ com um diálogo nas cordas em outro pulso de referência, com fragmentos rítmico-melódicos que vão aumentando a densidade, sendo interrompidos por um gesto em espiral da baqueta de feltro nas cordas que produz, por alguns segundos, uma sonoridade sem tempo medido. No final, o tempo é retomado com dez pulsos em um andamento próximo ao do momento B. É interessante notar que Beatriz se relaciona com o tempo medido com liberdade, imprimindo andamentos diferentes em cada parte, acelerandos ou mesmo um aumento de densidade que provoca uma outra percepção do tempo.

Em relação à organização das alturas e durações, apesar de a música se basear em um tempo métrico, apresentando logo de início uma figura ou motivo rítmico preciso, pode-se notar que o foco de Beatriz é o timbre: percussão corporal (no início), a baqueta no ferro de sustentação da harpa do piano, baquetas diferentes no suporte de madeira dos pedais, a baqueta de feltro na tábua harmônica, ataques nas cordas com baquetas, um gesto em espiral nas cordas com uma baqueta de feltro e pedal 3C acionado e, por fim, um glissando ascendente nas cordas mais agudas do piano com o lado contrário da baqueta de madeira. Toda essa gama de timbres produzida de diferentes maneiras foi bastante explorada em momentos anteriores de pesquisa sonora e na livre improvisação, e as escolhas de Beatriz ao compor sua música revelam a memória desse repertório de gestos e sons.

Uso o termo gesto de acordo com Costa (2003), a partir do referencial de análise de Brian Ferneyhough, professor e compositor inglês. Segundo Costa (2003, p. 101):

[...] o termo gesto, como a maioria dos termos usados na análise musical, é emprestado de seu sentido mais genérico e corporal e pode sugerir algo no sentido de um movimento que tem um percurso (começo, meio e fim) e que representa uma intervenção no ambiente, revestida de significado.

No decorrer dos anos em sala de aula, fazendo música junto com os alunos, tenho observado que sons diversos nascem de simples gestos e a eles são incorporadas intenções sonoras, que revelam o pensamento musical das crianças. Esses procedimentos acontecem com os mais novos e os mais velhos, com maior ou menor complexidade e consciência da 
intenção musical. É possível exemplificar essa afirmação com diversos momentos da exploração sonora e da livre improvisação de Beatriz, e também de seu processo de composição, reafirmando o que Brito escreve, referindo-se às crianças menores:

Seus interesses costumam centrar-se na exploração de gestos, de
intensidades, de velocidades, de alturas, de durações; na produção de sons
isolados e/ou em blocos, na pesquisa do teclado etc. Assim sendo, a
experimentação sonoro-musical das crianças parece ser guiada pela
consciência de que um repertório de gestos possíveis resulta em blocos de
sonoridades [...]. O conhecimento musical da criança nessa fase de sua vida
é, prioritariamente, um conhecimento de ordem intuitiva [...], conhecimento
com base na apreensão, na observação, na repetição e na imitação, na
vivência, enfim. Isto não significa, obviamente, que crianças mais velhas e
também os adultos não se guiem segundo princípios similares e, ainda, que
os processos de criação não misturem conhecimentos de ordens diversas
(BRITO, 2007, p. 84-85).

Como já foi dito anteriormente, o processo vivido por Beatriz na elaboração de sua composição revela muito de sua vivência musical com o piano, isto é, os gestos, a exploração e as descobertas formaram um repertório de possibilidades sonoras que ela, ao compor, acionou de forma intuitiva em alguns momentos e intelectualmente em outros. Dois momentos da livre improvisação usados depois na composição servem de exemplo: no primeiro, com uma baqueta de feltro nas cordas do piano, Beatriz faz um gesto em espiral (3min14s - 3min24s), no segundo, desliza a baqueta rapidamente para a direita e para a esquerda nas cordas agudas do piano $(3 \min 31 \mathrm{~s}-3 \min 40 \mathrm{~s})$. Segundo me disse depois da atividade, a sonoridade que resultou desses gestos a agradou bastante. Aulas depois, estruturando sua composição, toca o primeiro "gesto-som" sem uma intenção predefinida, mais como uma memória que veio à tona do que como uma escolha - o "gesto-som" simplesmente aconteceu. Em seguida, decide que já era o momento de terminar a música e, depois de alguns segundos, diz: "tive uma ideia". Lembra-se do segundo gesto e, por alguns instantes, empenha-se em encontrar o resultado sonoro exato, buscando o mesmo lugar que havia tocado e o mesmo modo de ação, com uma clara intenção. A memória a guia e, quando encontra, demonstra contentamento com o que tocou. É possível observar esse processo no diálogo transcrito abaixo $(7 \min 18 \mathrm{~s}-8 \min 30 \mathrm{~s})$ :

Beatriz: ... aí, a gente podia pegar um negócio pra começar [e] ir finalizando.

Professora: Ah! Já ir para um final.

Beatriz: Ir finalizando, que já tá ficando grande.

Professora: Tá. 
Beatriz: Aí, a gente vai finalizando... e como a gente finaliza? Ô! Já tive uma ideia! Pega essa parte daqui - e aponta com a baqueta as cordas agudas do piano, no lugar que havia tocado anteriormente.

Professora: Aquele som que você gostou?

Beatriz: Tava aqui. Deixa eu ver.

Nesse momento, Beatriz pega a baqueta de feltro, retoma o gesto anterior (o da espiral nas cordas da região grave) e busca o "gesto-som" de que se lembrara e que lhe parecia uma ótima ideia para o final da música. De imediato, não consegue o resultado sonoro que pretendia, então tenta novamente em outras partes até descobrir o som que tinha em mente e comentar:

Beatriz: Ficou legal. Aí você finaliza com... qualquer coisa... um som grave, uma coisa grave e aí você faz - e faz um gesto como se tivesse realizando um ataque com a baqueta sobre as cordas.

Na aula seguinte, lapidando sua composição, Beatriz decide transformar o resultado sonoro citado anteriormente em um outro: dez glissandos ascendentes na mesma região das cordas. Essa etapa de decisão não foi registrada, mas pode-se notar a substituição no vídeo $(9 \min 39 \mathrm{~s}-9 \min 46 \mathrm{~s})$.

Por fim, destaco a elaboração da composição de Beatriz. Ela apresenta uma primeira ideia, o motivo rítmico tocado em percussão corporal, reafirmando-o três vezes, mas variando o timbre a cada vez: na segunda, começa sendo tocado numa parte do suporte de ferro e termina em outra, que soa mais agudo; na terceira vez, o motivo ganha volume e mistura as duas alturas, compondo um outro timbre quando tocado em uníssono por nós duas; na quarta vez, é tocado só no suporte de ferro, soando mais grave.

O primeiro momento da composição foi determinado totalmente por Beatriz, inclusive a percussão corporal no início, que foi a solução encontrada por ela para algo que não conseguia fazer. Ela tentara tocar o motivo inicial nas cordas, mas não conseguiu o resultado sonoro que queria, largou a baqueta e começou a experimentar vários ritmos tocando nas pernas. Quando definiu o motivo rítmico, voltou-se para as cordas e o repetiu em lugares diferentes, até consolidar a forma final. 
Relembro que minha participação aconteceu a pedido da própria aluna, que conduziu a situação indicando o que queria que eu fizesse, o que tentei realizar o mais aproximado possível de sua concepção, apesar de que a maior parte da música acontece no âmbito da imprecisão quanto às alturas, durações ou intensidades. $O$ interesse maior de Beatriz era claramente no campo dos timbres, aí sim, ela indicava a região onde tocar, a ação - percutir, raspar, deslizar etc. - e a baqueta a usar. Certamente, o espaço da imprecisão como concepção musical fez com que minha interação no ato de tocar também sugerisse caminhos, mas as ideias sonoras e musicais foram de Beatriz.

\section{Professor e aluno fazendo música juntos?}

Embora não seja o foco principal desta pesquisa, parece-me importante refletir a respeito de uma questão que surgiu na descrição do processo criativo de Beatriz, também presente nos exemplos a seguir: professor e aluno fazerem música juntos contribui efetivamente para a formação musical do aluno?

Considero que, ao propiciarmos momentos em que aluno e professor fazem música juntos, usamos uma valiosa ferramenta para construir a relação professor-aluno e possibilitar aprendizados de ambas as partes. Jeffrey e Craft (2004) defendem uma abordagem pedagógica que conjugue o ensinar criativamente com o ensinar para a criatividade, em que professores e alunos coparticipem, propondo questões, identificando problemas em conjunto e debatendo possíveis soluções.

Certamente, o professor tem mais bagagem musical e experiência do que o aluno, mas, em propostas como essa, o professor transita entre duas posturas: numa, deixa de ser professor e os dois instrumentistas fazem música juntos; na outra, torna-se observador atento da atuação do aluno e do fluxo musical, para intervir com seu conhecimento no momento mais adequado e ampliar o repertório de possibilidades do aluno. Contudo, para transitar adequadamente entre uma postura e outra, é preciso que se guie por pressupostos diferentes da concepção tradicional de uma aula, em que o professor ensina e o aluno aprende. Segundo Brito (2004, p. 121), Koellreutter dizia: "Eu só respondo como professor, quando o aluno pergunta. Eu faço música com ele. A gente se autoeduca coletivamente por meio do debate, do diálogo”. 
Com essa postura, a aula tradicional de piano se torna um espaço agenciador de um fazer musical em construção, abrindo um leque de possibilidades no processo de formação musical do aluno e propiciando uma relação mais afetiva e cúmplice entre professor e aluno.

Para Koellreutter, um professor deveria se guiar, em primeira instância, pela observação e pelo respeito ao universo do aluno: seu conhecimento prévio, seus interesses e suas necessidades. Por isso, afirmava "que o professor não deve fazer da aula um monólogo, e sim partir sempre de um debate, partir das ideias dos alunos e aprender a apreender deles o que ensinar" (KOELLREUTTER, 1997 apud KATER, 1997, p. 132, grifos do original).

Acredito que seja possível estabelecer uma relação professor-aluno totalmente diferente da habitual, baseada no respeito ao aluno e no enriquecimento mútuo, possibilitando um espaço de intercâmbio de afetos, sentimentos e conhecimentos, musicais e outros.

Faz-se necessário salientar que construir esse espaço agenciador e transformador não é tarefa fácil, pois as concepções vigentes, em que a maioria de nós - professores de música fomos formados, estão construídas sobre um pensamento em que reinam a linearidade, as dicotomias, as hierarquias e a compreensão de um mundo segmentado, tanto no conhecimento como nas relações humanas. Transcender esses paradigmas é tarefa que exige grande disponibilidade e flexibilidade diante de um espaço onde as certezas são substituídas pelo "vir a ser", a uniformidade pela diversidade, a inércia pela iniciativa, a estabilidade pelo movimento e o controle constante pela liberdade responsável. Permitir esse novo espaço na sala de aula propicia um terreno profícuo para que o impulso criador floresça e se desenvolva.

Segundo Ostrower (1978, p. 27), a origem da criação se encontra na motivação interior, pois há tensões psíquicas no ser humano que o incitam ao fazer e, fazendo, ele próprio se refaz: "a criatividade, como a entendemos, implica uma força crescente; ela se reabastece nos próprios processos através dos quais se realiza”. Enfim, possibilitar um espaço criativo e integrador, onde professor e aluno façam música e criem juntos, pode ser benéfico para ambos, não só musical, mas humanamente.

Compreendemos, na criação, que a ulterior finalidade de nosso fazer seja poder ampliar em nós a experiência de vitalidade. Criar não representa um relaxamento ou um esvaziamento pessoal, nem uma substituição imaginativa da realidade; criar representa uma intensificação do viver, um vivenciar-se no fazer; e, em vez de substituir a realidade, é a realidade; é uma realidade nova que adquire dimensões novas pelo fato de nos articularmos, em nós e perante nós mesmos, em níveis de consciência mais elevados e mais complexos. Somos, nós, a realidade nova. Daí o sentimento do essencial e necessário no criar, o sentimento de um crescimento interior, em que nos ampliamos em nossa abertura para a vida (OSTROWER, 1978, p. 28). 


\section{3 "Mistério"}

O segundo exemplo (9min51s - 15min59s) disparador dessas reflexões pedagógico-musicais é a música "Mistério", composta por Laura, da qual descrevo o processo de finalização e apresento o depoimento de Laura sobre seu processo de criação. O interesse principal é compreender os recursos e as estratégias usados pela aluna, o que possibilita refletir sobre caminhos que auxiliem o professor na condução desse processo criativo e sobre a apropriação de conteúdos musicais a partir da criação.

A composição foi elaborada a partir da seguinte proposta: criar um música usando cromatismos, elemento musical que surgiu espontaneamente numa livre improvisação a quatro mãos - professora e aluna - e disparou o estudo de outros conteúdos musicais em aula.

\section{Apresentando Laura}

Laura é aluna da EMIA desde 2008, quando ingressou com 5 anos de idade. Paralelamente às aulas do currículo obrigatório, Laura frequentou o curso optativo de dança e coral, em 2011 e 2012. Começou suas aulas de piano no segundo semestre de 2011, as quais frequenta até este ano de 2014. Atualmente, além das aulas de piano, que são optativas, faz o curso de música, que escolheu este ano, cumprindo as orientações do currículo obrigatório para sua faixa etária.

Laura é uma criança quieta, não se expõe muito e faz o que se propõe com interesse e concentração, demonstrando gostar bastante de estudar piano. Reage com tranquilidade e segurança aos pequenos desafios propostos em aula. Apesar de não ter piano nem teclado em sua casa, segue as orientações de estudo com dedicação, indo à escola estudar uma vez por semana, por trinta minutos. Habitualmente, não traz composições para a aula, apesar de relatar que gosta de brincar e inventar músicas nas horas de estudo e demonstrar bastante alegria em improvisar e criar suas músicas quando lhe é proposto. 


\section{A livre improvisação e a noção de cromatismo}

Uma livre improvisação desencadeou a composição "Mistério". Não discorro aqui sobre a incorporação dessa prática nas minhas aulas, pois considero que o exposto nas páginas anteriores, na análise detalhada de "Música sem título" de Beatriz, é suficiente para esclarecer esse processo.

Antes da proposta da livre improvisação a quatro mãos, Laura já tinha feito essa atividade três ou quatro vezes, mas sempre como solista. A improvisação não foi registrada em vídeo, mas é referência para o estudo da composição de Laura, pois dali surgiram passagens cromáticas cuja sonoridade a encantou.

$\mathrm{Na}$ verdade, a sonoridade do cromatismo nos envolveu, aluna e professora, e buscamos repeti-la de diversas formas durante a improvisação. Em seguida, o único caminho possível era eleger o cromatismo como conteúdo a ser estudado até o final da aula. Assim, a sonoridade recém-descoberta por Laura ganhou nome, revimos auditiva e intelectualmente o conceito de semitom, ouvimos peças musicais com cromatismo evidente e, por fim, praticamos o dedilhado comumente usado nos cromatismos por todo o piano. Ao final da aula, escalas cromáticas foram tema da lição de casa de Laura, e propus que ela criasse uma música inspirada no cromatismo. Na aula seguinte, ela me presenteou com "Mistério".

\section{O encanto pelo cromatismo}

A primeira reflexão disparada pela livre improvisação trata do prazer que Laura demonstrou ao executar escalas cromáticas ao piano.

A partir da concepção de que as ideias das crianças partem sempre de algo concreto, o motivo central da composição "Mistério" surgiu das passagens cromáticas que emergiram espontaneamente na livre improvisação e muito agradaram Laura. Ao observar que o cromatismo a tinha encantado, debruçamo-nos sobre ele: nomeando, aprendendo o dedilhado tradicional $^{119}$ e exercitando escalas cromáticas por toda a extensão do piano. Sua alegria foi perceptível, provocada pela sensação físico-sonora ao deslizar da mão sobre o teclado do

\footnotetext{
${ }^{119}$ Começando pela nota dó, por exemplo: 131312313131231 ....., movimento ascendente; 2131313 $21313213 \ldots$. e assim por diante, no movimento descendente.
} 
piano. De minha prática pianística, recordo muitos momentos de satisfação ao tocar escalas de todos os tipos no piano.

Delalande (1995, p. 5, tradução nossa) afirma que a música está intimamente ligada ao gesto, seja quando tocamos um instrumento, dançamos ou mesmo quando a ouvimos. $\mathrm{O}$ autor ainda aponta que "a criança conhece, por assim dizer, o mundo exterior por meio de suas mãos e gestos. Ela adquire um certo número de esquemas motores que lhe dão domínio do seu entorno. O pianista [...] também adquire, por meio do exercício, automatismos motrizes". ${ }^{120}$ Pode-se comparar, também, o prazer que o movimento corporal causa às crianças com a profunda fonte de prazer que "as escalas que sobem sozinhas, às vezes," são para os pianistas (Delalande, 1995, p. 17-18, tradução nossa).

\section{"Mistério" - a aula}

Descrevo a aula em que Laura me apresentou sua composição "Mistério", sua lição de casa da aula anterior.

Ela entrou na sala para sua aula semanal de piano com uma postura mais expansiva e vivaz, bem diferente de sua quietude e discrição habituais. Sua alegria chamou minha atenção e brinquei com ela:

Professora: Oi, Laura! Viu o passarinho verde?

Laura: Fiz o que você me pediu - disse, esboçando um leve sorriso.

Professora: O quê?

Laura: A música... do cromatismo - e, assim, a aula começou.

Destaco esse pequeno diálogo para mostrar o envolvimento significativo de Laura com seu processo criativo. Em décadas de sala de aula junto a crianças, posso afirmar que elas se revelam a nós por meio de pequenas atitudes, expressões ou poucas palavras. Assim, Laura se mostrou por essa nova vivacidade e ao sorrir discretamente quando respondeu "fiz o que você me pediu", apresentando sua música. Participar, criar, envolver-se são componentes que podem agregar significação à aula de piano, além de serem recursos importantes para o próprio aprendizado. Campos (2000, p. 38) afirma a importância da participação ativa do

120 "El niño toma conocimiento, por así decirlo, dle mundo exterior por medio de sus manos y sus gestos. Adquiere un cierto número de esquemas motrices que le dan dominio sobre su entorno. El pianista[...] adquiere, por medio del ejercicio, automatismos motrices" (Delalande, 1995, p. 5). 
aluno no aprendizado de piano, "como ser investigador e criador, não mais como apenas um intérprete". Gainza reforça o valor do protagonismo do aluno em seu aprendizado como condição para um saudável desenvolvimento musical:

[...] a pessoa que aprende música deve fazê-lo a partir de si mesma, constituindo-se protagonista ativa de sua aprendizagem. [...] Se não permitimos ao aluno que pergunte, que invente e que processe suas próprias experiências, estamos o condenando a converter-se em um recipiente passivo de dados que lhe são fornecidos de fora para dentro, o que dificultará, naturalmente, seu processo de desenvolvimento ${ }^{121}$ (GAINZA, 2008, p. 175176, tradução nossa).

Depois de tocar sua música, Laura me informou que ainda faltava um final, pois não havia conseguido pensar em um. Começamos, então, um trabalho de criação para ajudá-la a descobrir o final que considerasse mais adequado à sua música. A seguir, o diálogo e a descrição de alguns dos procedimentos adotados:

Professora: Você acha que a duração da música está curta, longa ou o tempo certo?

Laura: Queria que fosse um pouco mais comprida.

Professora: você pensa em usar mais uma vez o cluster que me disse que parece um susto? Lembra que me disse que era pra deixar a música mais interessante?

Laura: Eu podia deixar bem pro finalzinho da música.

Professora: Pode ser... precisa experimentar.

Chamei sua atenção para a região do teclado que predominava em sua música: a região média. Sugeri que ela poderia usar outras regiões, pois a mudança poderia soar como uma novidade. Laura ouviu, pensou um pouco e disse que queria mesmo ficar na região média, mas, no fim do processo, quando já decidira dois clusters para o final da música (11min29s $11 \mathrm{~min} 37 \mathrm{~s}$ ), voltou atrás e acrescentou uma pequena figura cromática na região grave (11 min38s - 11min46s), o que acredito que tenha sido uma boa ideia, pois deu mais equilíbrio à peça.

Outro proposta para ajudá-la foi a de tocar a música até o final provisório e seguir improvisando, pois a partir da improvisação poderia surgir alguma ideia que a agradasse e fosse interessante para o fim que almejava. Assim foi feito, e Laura gostou de um cromatismo

\footnotetext{
121 “[...] la persona que aprende música debe hacerlo desde sí misma, constituyendose en protagonista activa de su propio aprendizaje. [...] Sí no le permitimos al alumno que pregunte, que invente, y que procese luego sus propias experiencias, lo condenamos a convertirse en un recipiente pasivo de datos que le son suministradosdesde afuera, lo cual dificultará, naturalmente, sus procesos de desarollo" (GAINZA, 2008, p. 175176).
} 
que tocou em movimento contrário, ideia que acrescentou depois do cluster $(10 \mathrm{~min} 45 \mathrm{~s}-$ 10min55s). Dessa forma, continuamos o trabalho de criação até Laura se sentir satisfeita com a finalização de sua música.

Ao rever as anotações e o vídeo, considero relevante destacar uma questão sobre a intervenção do professor no processo de criação do aluno. Mesmo que a intenção seja ajudá-lo a dar forma a suas próprias ideias, essa situação se mostra bastante delicada. O professor que busca uma postura de compartilhamento de saberes, mas é consciente de seu papel de orientador e de guia que conduz o caminho do aluno, mas não caminha por ele, precisa estar atento para conseguir o equilíbrio de preservar a ideia original do aluno e ajuda-lo a ampliar e agregar significados e conhecimentos ao processo criativo.

Em diversos textos, Koellreutter salienta a importância de uma nova concepção do que seria ser professor, ainda muito enraizada nos paradigmas do século XIX, de que o professor é detentor do saber absoluto. Koellreutter propõe mudanças:

\footnotetext{
Numa escola moderna, numa época de profundas mudanças socioculturais como a nossa, o professor apresenta aos alunos sempre novos problemas; pois as perguntas têm mais importância do que as respostas. Numa escola moderna, as soluções não são mecanicamente fornecidas ao aluno, mas sim resultam de um trabalho comum de todos, que dele participam. É que nesse ambiente desaparece o dualismo tradicional professor-aluno [...]. Deve ser a nossa Escola um laboratório, onde se cultiva o diálogo entre professores e alunos, onde se procura penetrar em tudo, elucidar e objetivar tudo que pode ser apreendido. Desejo que a nossa Escola dê a impressão de que toda a vida é uma grande experiência, um material a ser estudado (KOELLREUTTER, 1997f, p. 53-57).
}

A partir dessa premissa, tentei não conduzir a criação de Laura, mas oferecer recursos para ampliar suas percepções, auxiliando em suas escolhas, porém receio que a certeza de tal procedimento nunca é absoluta. No entanto, considero que a avaliação constante do processo da aula e a observação atenta de reações, comportamentos e desenvolvimento musical do aluno podem indicar se estamos no caminho correto.

\section{Sobre o depoimento de Laura}

Uma semana após a aula descrita, gravamos em vídeo o depoimento de Laura sobre seu processo de criação de "Mistério". Falar a respeito de seu processo, gravar e ouvir a própria fala têm sido recursos usados em diversos momentos de suas aulas de piano. 
A convivência com as crianças tem me revelado que elas gostam muito de usar tecnologias, mesmo as mais simples como um gravador de áudio ou de vídeo que há na maioria dos celulares atualmente. Esses recursos tecnológicos fazem parte do cotidiano de grande parte das crianças e adolescentes brasileiros, nas diversas classes sociais e, para o professor, podem ser ferramentas valiosas em sala de aula e, posteriormente, meio de análise para um aprofundamento do pensar/fazer musical das crianças. Beineke (2009, p. 145) ressalta que a perspectiva da criança sobre sua relação com a música muitas vezes não é percebida no momento em que elas estão compondo, mas sim quando "elas falam sobre o que pensam das suas experiências em sala de aula". Dessa forma, mesmo após a gravação, a fala da Laura serviu para retomarmos juntas algumas de suas afirmações, aprofundando sua consciência tanto dos conceitos musicais emergentes como de seu próprio processo musical.

Burnard (2000) defende algumas proposições que corroboram com a proposta feita à Laura de falar sobre seu processo de composição. A pesquisadora defende que os professores estimulem as crianças a discutir e refletir sobre suas experiências musicais, pois essa reflexão pode ajudá-las a ter uma consciência mais profunda de seu fazer musical:

Nossa meta como educadores musicais deve ser o de proporcionar uma educação musical que tenha como foco experiências autênticas atuando como improvisadores e compositores, ao invés de atuar somente a partir de um modelo predefinido. Posteriormente, devemos encorajar e ajudar as crianças a pensarem de forma crítica e criativa [...] As crianças devem ser encorajadas a: (i) discutir o que é intrínseco à sua própria experiência musical; (ii) identificar-se não apenas como 'reprodutores' de música, mas também como 'criadores' de música; e (iii) a refletir sobre o que é improvisar e o que é compor. Se reconhecemos a importância da voz das crianças, então eles irão construir socialmente as maneiras de improvisar e compor na sala de aula. Compartilhar o conhecimento irá ajudar as crianças a reconhecerem $o$ porquê elas estão fazendo uma determinada atividade e $o$ $q u \hat{e}$ elas estão fazendo, conduzindo-as a uma maior consciência em relação ao como elas estão fazendo isso. Assim, ao dar às crianças a oportunidade de articular os seus conhecimentos, estamos aprimorando a aprendizagem ${ }^{122}$ (BURNARD, 2000, p. 21-22, tradução nossa, grifos nossos).

\footnotetext{
122 "Our aim as music educators should be to facilitate a form of music education that focuses on genuine experiences of children being improvisers and composers rather than acting out a pre-defined model. Subsequently, we must encourage and assist the children to think critically and creatively. [...] Children should be encouraged to: (i) discuss what it is that is intrinsic to their own musical experience; (ii) identify themselves not only as music makers but as music creators; and (iii) encouraged to reflect on what it is to improvise and compose. If we acknowledge the importance of the words of children then they will socially construct the ways they compose and improvise in the classroom. Sharing understanding will help the children to recognise why they are doing a certain activity and what they are doing, leading to an awareness of how they are doing it. Thus, by giving children the opportunity to articulate their understandings we enhance learning" (BURNARD, 2000, p. 21-22).
} 
Seguirei, então, com algumas reflexões a partir da transcrição do diálogo abaixo $(11 \min 48 s-15 \min 59 s)$ :

Laura: Essa música se chama "Mistério".

Professora: Tá. E aí, você vai falar o quê?

Laura: Essa música começou a ser feita quando eu e a professora Berê estávamos improvisando no teclado, ${ }^{123}$ daí saiu essa ideia do cromatismo, num momento da improvisação, saiu a ideia do cromatismo.

Professora: Mas você já sabia que isso se chama cromatismo?

Laura: Não, não sabia; por enquanto eu não sabia. Daí saiu isso, daí ela me ensinou o nome... ela me ensinou como é que se chamava e como é que se fazia no teclado.

Professora: Ah! A ideia dos dedos, né? Isso que você tá falando que eu te ensinei? Ah! A gente foi... o dedilhado, né?

Laura: É... a brincadeira da aranha.

Professora: Como é o quê? Brincadeira do quê?

Laura: Ela se chama brincadeira da aranha.

Professora: O dedilhado, a gente chamou da brincadeira da aranha. ${ }^{124}$

Laura: Daí ela mandou fazer uma música e saiu essa música que chama "Mistério". Também brincando no piano saiu a música! Uma parte dela.

Professora: E por que essa música começa com... lembra o "Palito chinês", no começo, né?

Laura: Porque no começo eu tava sem muita ideia pra começar. Isso saiu bem na improvisação, na verdade. É o começo da minha improvisação do "Palito chinês". ${ }^{125}$ Saiu na hora que a gente tava improvisando, eu e a Berê. Daí, a gente estava improvisando e saiu isso. E, na hora de começar, eu fiquei brincando, brincando e fiquei sem ideia pra começar e aí comecei com isso, essa parte.

Professora: E que parte da música você achou que foi bem legal?

\footnotetext{
${ }^{123}$ Laura se refere ao teclado do piano e não ao teclado eletrônico. Ela usa esse termo porque muitas vezes improvisávamos também nas cordas do piano.

124 Brincadeira da aranha é o apelido que demos às escalas cromáticas, na alusão à imagem dos dedos percorrendo o teclado.

${ }^{125}$ Laura se refere ao começo da variação $(10 \min 07 \mathrm{~s}$ - 10min13s) que ela havia criado para "Palito chinês", primeira peça musical de Palitos chineses, de Gainza.
} 
Laura: Eu gostei mais da parte da música dos sustos, porque tá bem leve a música e daí do nada vem um... um susto assim! (Laura faz o gesto com as mãos como se tocasse o cluster.)

Professora: Que parte é? Mostra pra gente.

Laura: Tem essa que é a primeira parte - e toca.

Tem aqui... - e toca outra parte.

Ainda tem outra parte que toca assim - e toca novamente.

Professora: Quando você fez a música, você pensou isso? De fazer um susto?

Laura: Sim.

Professora: Aí você usou esses clusters.

Laura acena positivamente com a cabeça.

Professora: Mais alguma coisa que você queria falar dessa música?

Laura: Hummm... Que eu não sabia, do nome... a questão do nome. Eu não sabia qual nome pôr. Daí eu fiquei nisso! Daí, né, minha mãe falou, tipo assim: “tá sendo um mistério pra você pôr o nome nessa música, né, como todas”. Daí eu peguei e pus o nome dela de "Mistério".

A professora ri.

Laura: Eu achei legal o negócio assim... mistério.

Professora: Você acha que combina com a música?

Laura: Eu acho.

Professora: E... como todas, por quê? Não entendi. Como assim?

Laura: Porque todas as músicas é uma coisa pra mim [sic] escolher o nome; é muito difícil.

Professora: Ah, é? Difícil?

Laura: Algumas delas nem fui eu que escolhi direito, foi mais minha mãe. Minha mãe deu uma ideia, eu elaborei a ideia e pus o nome, ou ela falou o nome e eu pus o nome mesmo. Porque pra mim, a coisa mais difícil da música não é inventar ela [sic]; pra mim inventar é bom, eu brinco no piano um monte de vezes. Pra mim, inventar é bom, é legal, o meu difícil é por o nome da música [sic].

O depoimento de Laura me fez refletir sobre os diversos aspectos da relação das crianças com a criação musical e a aula de piano como agenciadora dessa relação. Também pretendo expor ideias que corroborem com o encontro criança-música-criação de forma significativa, como aconteceu com Laura no contexto descrito anteriormente. 
Uma primeira particularidade que se pode observar nas palavras de Laura é sua forma de se relacionar com a criação. Para ela, o processo de criação de uma música é uma brincadeira, um jogo: “[...] pra mim, inventar é bom, eu brinco no piano um monte de vezes”.

As palavras acima reafirmam o que Brito (2007, p. 70) indica: “As crianças cantam ou tocam sem se preocuparem com regras, estilos, ou mesmo, com a permanência do que fazem". Elas se relacionam com o sonoro e com o musical da mesma forma que brincam e, nesses momentos de puro jogo, apreendem e aprendem sobre o mundo, constituindo um conhecimento significativo. Laura demonstrava essa postura ao me apresentar sua composição e quando falava sobre sua música.

Como Brito (2007, p. 70) afirma, do contato e da interação com o entorno "emergem mudanças contínuas que agregam, ao fazer musical, variáveis, possibilidades, condições, novos conhecimentos". Nesse caso, as possibilidades e os novos conhecimentos surgiram do contato de Laura com o instrumento e com a música, por meio de explorações sonoras, melodias tiradas de ouvido, partituras, improvisações, exercícios técnicos, conversas, enfim, o verdadeiro caldeirão de abordagens musicais, que constituem as aulas semanais de piano e seus poucos momentos individuais de estudo.

É relevante ressaltar também a consciência de Laura sobre o processo, reconhecendo que as passagens cromáticas da livre improvisação a 4 mãos desencadearam a elaboração da música ("Essa música começou quando eu e a professora Berê estávamos improvisando no teclado, daí saiu essa ideia do cromatismo [...]") e acrescentando o conceito de cromatismo a seu repertório como novo conhecimento e nova possibilidade de criação. Ao ser interpelada, diz que, a partir dessa descoberta espontânea, aprendeu o nome cromatismo, o dedilhado mais usual das escalas cromáticas e a tocá-las em movimentos ascendentes e descendentes. Laura também relaciona sua composição com o exercício das escalas cromáticas (brincadeira da aranha) e com a experimentação.

Considero que a verbalização de sua experiência fez com que ela se apropriasse mais conscientemente do conhecimento adquirido. Desenvolver uma prática reflexiva com o aluno pode contribuir para que ele forme um conhecimento musical significativo, além de ampliar a natural especificidade do estudo de um instrumento musical.

Além do brincar descomprometido no teclado do piano, Laura lançou mão de um repertório conhecido (isto é, que já estava na mão, como dizem os pianistas), usando a 
variação que fizera sobre "Palito chinês" para ajudar seu processo criativo, para aquecer e deixar que as ideias surgissem: “[...] E, na hora de começar, eu fiquei brincando, brincando e fiquei sem ideia pra começar e aí comecei com isso, essa parte”. Nota-se que o fato de ela ter incorporado a sua música algo que já havia feito não a incomodou de forma alguma, o que encontra ressonância nas análises de Beineke, que conclui que:

[...] as crianças veem com naturalidade a ideia de que podem utilizar em seus trabalhos ideias que surgiram em trabalhos de outros grupos. Segundo Mardell, Otami e Turner (2008, p. 118), quando as crianças têm espaço para partilhar suas ideias e refletir a respeito delas, conseguem construir um corpo de conhecimento coletivo sobre o objeto em questão, permitindo que elas sigam modificando e adicionando ideias e construindo compreensões coletivas sobre como o grupo trabalha (BEINEKE, 2011, p. 101).

A atitude de Laura, clarificada pelas ideias de Beineke, pode fornecer pistas a nós professores sobre a liberdade que as crianças têm com a composição, indicativa de uma compreensão da criação diferente da do fazer musical adulto. Além disso, é bom lembrar que as crianças têm muitos recursos e sabem usá-los intuitivamente quando lhes é dado um espaço de protagonismo e de confiança em suas possibilidades de ação.

A livre experimentação das possibilidades cromáticas no teclado do piano, denominada por Laura de brincadeira, permitiu que as ideias surgissem e tomassem forma, mais uma vez, defrontamo-nos com o espaço possibilitador de um fazer criativo. Aqui, é pertinente citar Brito, que vem se dedicando a valorizar o fazer musical das crianças e a influência do espaço educacional como possível agenciador de processos musicais significativos:

Brincando as crianças desenvolvem recursos, constroem conhecimentos e reorganizam continuamente as experiências, de modo que da vivência com o musical emergem conquistas que transformam qualitativamente as experiências. Evidentemente, o ambiente é determinante nesse processo [...] (BRITO, 2007, p. 78).

A respeito da construção do pensamento musical de Laura, ao escutar atentamente a sua música "Mistério", nota-se como a elaboração musical acontece a partir do próprio tocar. Intuitivamente em alguns momentos e conscientemente em outros, ela usa princípios de organização sonora como repetição, inversão de figuras, movimentos melódicos contrários e paralelos, contrastes etc. Tomando como exemplo o contraste entre a melodia cromática e o cluster, percebe-se em sua fala seu prazer e sua total consciência da sensação de imprevisibilidade provocada pelos clusters: "Eu gostei mais da parte da música dos sustos, 
porque está bem leve a música, daí, do nada, vem um susto assim”. Situações como essa podem indicar ao professor como se estrutura o pensamento musical dos alunos, além de, potencialmente, se constituírem em valiosas estratégias pedagógicas para a construção do conhecimento musical, afirmação corroborada por Brito (2007, p. 184):

[...] as criações instrumentais, por sua vez, evidenciam as estruturas de pensamento, as relações com o ambiente, a consciência com relação ao espaço-tempo, além de explicitarem aspectos musicais específicos: o conhecimento intuitivo ou intelectual, a técnica dos instrumentos, os códigos de registro etc.

É importante reiterar, que para que essas importantes evidências emerjam, é necessário um espaço educacional que possibilite a criação, a construção de significados e conhecimentos, o que só acontecerá se o professor estiver disposto a escutar atentamente o aluno e a incorporar, em sua prática, proposições que estimulem um fazer mais criativo. Como já foi dito, assumir essa postura é difícil para muitos professores de piano, devido a sua formação musical, em que a criação só tinha lugar nas aulas de composição, e só depois de muitos anos de estudo. Campos (2000, p. 34) nos alerta que não é fácil ensinar estimulando a criatividade, a imaginação e o desenvolvimento da expressão dos alunos, mas que a prática pode ser muito gratificante, ainda mais se criarmos um espaço de possibilidades onde ideias musicais possam emergir e se concretizar. Brito define esse espaço como:

Espaço disposto a capturar, nos "entre-espaços" da educação musical, o fazer musical da infância, percebido na condição de contínuo jogo de fazer e desfazer lugares, domínios, conhecimentos...; percorrendo trajetórias inusitadas ou conhecidas; produzindo ramificações, rizomas, devires. Jogo que, ao auditor, instaura outros (e novos) ouvidos, necessários à apreensão da música menor das crianças que, por sua vez, desliza e deságua em planos de aproximação e/ou afastamento dos planos maiores do fazer musical dominante (BRITO, 2007, p. 78, grifos do original).

Para agenciar esse espaço, é necessário transformar a própria concepção de educação musical. Koellreutter (1997b, p. 30-31) defendia que era "necessário libertar a educação e o ensino artísticos de métodos obtusos", pois "a fadiga e a monotonia de exercícios conduzem à mecanização tanto dos professores quanto dos discípulos" e, em oposição, o espírito de pesquisa e a criação são indispensáveis em todo o ensino artístico.

Gainza $(2002,2008,2013)$ há tempos aponta a importância de se buscar uma maior fundamentação às práticas, isto é, transcender o legado das duas primeiras épocas da educação musical que incorporaram o corpo/movimento e a criatividade às práticas 
pedagógico-musicais, acrescentando a consciência adquirida pela reflexão constante a respeito do processos educacionais. Gainza (2008, p. 175) se estende bastante sobre essa questão e aponta as décadas de 1970 e 1980 como promotoras de muitos processos criativos, mas de forma pouco reflexiva e sem sistematização sobre os aspectos levantados, e propõe como tarefa da atualidade, mais do que buscar técnicas de improvisação ou exercícios criativos, empenhar-se em ampliar e aprofundar um pensamento criativo que fundamente as ações e práticas pedagógicas.

Por fim, ao rever diversas vezes a gravação da música e o depoimento de Laura, faço uma última reflexão a respeito da aula de piano como deflagradora de experiências singulares no encontro entre música, aluno e professor. Experiências que só podem acontecer se estivermos abertos a elas, permitindo o "complexo tempero entre o planejado e o vivido" (NEELANDS, 2000, p. $54^{126}$ apud Cremin, Burnard, Craft, 2006, p. 117). Com certeza, é preciso ter um planejamento e segui-lo, mas, simultaneamente, deve-se estar atento para as possibilidades que possam surgir no caminho e não deixar que o momento disparador de uma experiência única se perca. Experiência repleta de significado e conteúdos musicais e de vida. Não é possível prever esse momento especial, em que professor e aluno, totalmente integrados no fazer, compartilham uma experiência, mas, sim, estarmos atentos a ele, ao que pode vir a acontecer.

Koellreutter (1997f, p. 53-55) afirmava que "somente na medida em que o nosso espírito for criador que fazemos experiências" e, para ele, espírito criador é "o espírito que sempre se renova, que sempre rejuvenesce e nunca se detém [...] que, sempre duvidando, procura, investiga e pesquisa", exigindo de nós uma postura flexível e aberta, de constante construção.

Ana Cristina Rossetto Rocha, flautista e educadora musical, alude a uma viagem na qual se navega por um mar de possibilidades, e para que isso possa acontecer é preciso:

Traçar, retraçar e revalidar a todo instante entre os viajantes um plano conjunto, composto e variável, que não se limita a um trajeto de um ponto a outro... Penso que essa forma de navegação, guiada por um plano aberto, e que se alimenta dos ventos do acontecimento, configura-se como uma pedagogia que nesse trabalho nomeio como pedagogia do encontro (ROCHA, 2011, p. 29).

\footnotetext{
${ }^{126}$ NEELANDS, J. Drama sets you free or does it? In: DAVISON, J.; MOSS, J. (Eds.). Issues in English teaching. London: Routledge, 2000.
} 
Agenciar um espaço onde se construa uma nova relação professor-aluno e aluno-música e haja uma experiência significativa para ambos talvez possa nos levar até essa pedagogia do encontro. O "Mistério" de Laura foi uma dessas experiências completas e únicas que se "alimentou dos ventos do acontecimento" e transformou professora e aluna.

\section{4 "O gigante" e "Ideia musical"}

"O gigante" (16min - 16min57s) e "Ideia musical" (16min58s - 22min12s) são as duas últimas composições selecionadas para este trabalho e foram compostas por Arthur, aos 8 anos de idade. A primeira é uma história musicada ou uma música historizada, ${ }^{127}$ e a segunda não se configura exatamente como uma composição mas, como o próprio nome deixa claro, uma frase musical. As músicas de Arthur reiteraram minha convicção, presente nos exemplos anteriores, de que a exploração sonora do instrumento pode ser um precioso recurso para a expressão musical dos alunos e que as ideias sonoro-musicais das crianças surgem a partir do próprio fazer musical.

\section{Apresentando Arthur}

Arthur é aluno da EMIA desde 2009, quando tinha 6 anos de idade. Ele frequenta as aulas em grupo com linguagens integradas do currículo obrigatório, desde seu ingresso até o presente ano de 2014, e, desde o primeiro semestre de 2012, tem também aulas de piano.

Arthur é muito imaginativo em tudo que faz. Gosta muito de inventar histórias, até pequenos roteiros, e transita do som à imagem e da imagem ao som com muita facilidade. Suas ideias brotam com tamanha fluidez que um dos desafios que lhe tenho proposto é organizá-las e dar forma a uma de cada vez, pois, em muitos momentos, esse turbilhão de ideias acaba por dispersá-lo, afastando-o do objetivo primeiro, que é fazer música. Depois de 2 anos trabalhando juntos, noto que Arthur vem trilhando um caminho de amadurecimento musical.

\footnotetext{
${ }^{127}$ Em diversas aulas, brincava com Arthur, provocando-o: “Afinal, essa é uma história musicada ou uma música historizada?"
} 


\section{O som, a imagem, a história e a música}

"O gigante" (16min - 16min57s) é uma composição que nasceu do encantamento de Arthur por uma sonoridade que o remeteu a uma imagem, que disparou uma história e, por fim, transformou-se em uma música. Esse processo criativo começou com a exploração sonora do piano aberto.

Arthur tinha 8 anos quando compôs "O gigante", numa de suas primeiras aulas de piano. O processo começou quando perguntei onde ele imaginava que o som do piano era produzido. A partir dessa pergunta, desenvolveram-se algumas etapas de trabalho: olhar o piano fechado e imaginar o que teria dentro dele, "tirar a roupa do piano", explorar seu mecanismo, desenhá-lo e fazer música.

Minha prática com as crianças indica que é fundamental ter tranquilidade e acompanhar as descobertas do aluno no processo de exploração. Em certos momentos, também é importante assumir a postura de observador que só valida a prática autônoma dos alunos; em outros, o professor deve ser um facilitador, que instiga, estimula e auxilia o aluno a organizar as percepções e ideias sonoras que possam surgir. Além disso, muitas vezes o processo de criação é deflagrado no momento em que a criança se encanta pelo som. A partir daí, a pesquisa das possibilidades sonoras que mais agradam vai gradativamente se transformando em improvisação e as ideias musicais vão surgindo do próprio tocar. Nessas pequenas invenções, a intenção conduz a escolha, a ordenação dos sons que se quer manter e a exclusão dos que não encantam. A curiosidade é elemento fundamental desse processo, pois leva às descobertas, aos encantamentos e ao florescimento da imaginação.

As sugestões do National Advisory Committee on Creative and Cultural Education (NACCCE, 1999), Jeffrey e Craft (2004, p. 7), que destacam o estímulo à curiosidade espontânea das crianças como um dos aspectos fundamentais para uma proposta criativa de ensino, confirmam minha percepção empírica citada acima.

Em outro artigo, Cremin, Burnard e Craft declaram o acompanhamento e o suporte às descobertas das crianças sem interferências (standing back) recomendáveis para um ensino para a criatividade. Em suas palavras:

Standing back foi considerado fundamental para possibilitar ao aluno o próprio controle e engajamento, promovendo sua autonomia e a oportunidade de dominar o aprendizado a partir de seus próprios interesses. Ao procurar se colocar nessa posição de stand back, os professores 
possibilitam que os alunos sejam agentes de sua aprendizagem e, por outro lado, permitem aos próprios educadores que percebam o comportamento e as ações das crianças, ampliando sua compreensão sobre como elas pensam dentro de seu próprio processo ${ }^{128}$ (CREMIN; BURNARD; CRAFT, 2006, p. 113, tradução nossa).

Embora as pesquisadoras se refiram sempre a contextos de grupo, creio ser possível transpor essas ideias para situações individuais, como o processo criativo de Arthur. Em certos momentos, permitir que sua curiosidade e seu interesse aflorem e adotar uma postura de standing back, dando espaço para que ele aprenda a partir de suas próprias descobertas, tem-se mostrado mais produtivo do que conduzir a aula segundo minhas intenções. A criação de "O gigante" é um exemplo positivo de um processo que partiu da fértil imaginação de Arthur e do espaço para que as descobertas se transformassem em música.

A composição da música conjugou sons e associações, resultando numa organização de formas sonoras impregnadas de imagens ou, talvez, de imagens impregnadas de sons.

Ostrower (1978, p. 20-22) afirma que as associações estão no cerne de nossa imaginação e que conectam memórias e experiências anteriores repletas de um sentimento de vida, portanto muito significativas. Apesar de conexões de foro íntimo, esse processo está mergulhado na cultura, constituindo-se uma interligação entre o individual e o cultural, transitando de um ponto a outro. Reforça, ainda, que o homem é um "ser simbólico por excelência, ele concebe abrangências recíprocas: do único dentro do geral, do geral dentro do único". A música do Arthur foi disparada pelo sonoro, mas galgou outros lugares e a imaginação foi o trem que o conduziu nessa viagem.

É possível identificar que a ênfase da música "O gigante" são as associações simbólicas a partir do sonoro e do imaginário de Arthur. Delalande (1995, p. 16, tradução nossa) explica as associações simbólicas em música a partir da concepção de que a música tem "organizações da matéria sonora" que "evocam um movimento, uma situação vivida, ou inclusive e, justamente, a causa de tudo isso, os sentimentos". E o autor continua:

Porque os sentimentos estão associados a uma certa experiência dos próprios movimentos, da própria respiração. Uma pessoa está vivaz quando está contente, lenta quando sonha acordada. Nossos gestos são característicos de

\footnotetext{
128 "Standing back was considered central to learner ownership and engagement, fostering autonomy and the opportunity for children to follow their own interests and shape their learning so that it was individually tailored. Teachers looked for opportunities to stand back to enable learners to gain agency in their learning, which in turn enabled them as educators to notice children's behaviour and actions, imputing understanding of their thinking in the process" (CREMIN; BURNARD; CRAFT, 2006, p. 113).
} 
nossas emoções e estão inscritos na música [...]. O que é seguro e amplamente constatado na maioria das culturas é que as condutas musicais têm, em geral, uma intenção simbólica, quer dizer que os músicos não fazem som pelo som em si mesmo, nem estruturas sonoras pelas próprias estruturas sonoras, mas sim que tudo isso remete a outra coisa, e essa "outra coisa" pertence à ordem das imagens ou dos afetos ou da mitologia ${ }^{129} 130$ (DELALANDE, 1995, p. 22, tradução nossa).

Delalande aborda a prática musical infantil a partir de três formas de atividade correspondentes aos estágios piagetianos: "a pesquisa do som e do gesto nada mais é do que um jogo sensório-motor, a experiência e a significação em música se aproximam do jogo simbólico, e a organização é um jogo de regra"131 (DELALANDE, 1995, p. 16, tradução nossa).

Ao refletir sobre o processo de criação de Arthur a partir das premissas da pesquisa de Delalande, observa-se que ele transitou naturalmente de uma forma de atividade descrita pelo pesquisador a outra. $\mathrm{O}$ início do processo foi a pesquisa das possibilidades sonoras do piano aberto, quando Arthur mesclou gestos e sons, numa atividade muito próxima à primeira fase a que o pesquisador se refere. Espontaneamente, as sonoridades alcançadas dispararam seu imaginário e o jogo simbólico começou quando ele associou os glissandos nas cordas aos "passos do gigante". Surgiram, então, imagens de sons e sons de imagens que foram sendo organizados por Arthur até resultar em sua música.

Apesar de descrevê-las linearmente, esclareço que essas fases não foram sucessivas, mas se entrelaçaram, o que se relaciona à ideia postulada por Brito (2007) a partir das pesquisas que levaram à teoria do dinamicismo, de Esther Thelen (de 1998), ${ }^{132}$ entrecruzando-a com Delalande. Brito (2007, p. 73-74) esclarece que a teoria do dinamicismo de Thelen

\footnotetext{
129 "Porque los sentimientos están asociados a una cierta experiencia de los propios movimientos, de la propia respiración. Uno está vivaz cuando está contento, lento cuando sueña. Nuestros gestos son característicos de nuestras emociones y están inscriptos en la música [...]. Lo que es seguro y ampliamente constatado en la mayoría de las culturas es que las conductas musicales tienen en general una intención simbólica, es decir que los músicos no hacen sonido por el sonido mismo, ni estructuras sonoras por las estructuras sonoras mismas sino que todo eso remite a otra cosa, ua esa "otra cosa"pertenezca al orden de las imágenes o de los afectos o de la mitología” (DELALANDE, 1995, p. 22).

${ }^{130}$ É interessante, aqui, destacarmos que, na segunda metade do século XX, a proposta musical de Pierre Schaeffer ao criar a música concreta foi justamente de se opor a isso, que Delalande afirma como realidade da maioria das culturas, direcionando o foco para o sonoro, o som em si mesmo, destituído das imagens, das significações, enfim, o som puro e a escuta reduzida.

131 "La investigación del sonido y del gesto no es sino un juego sensorio-motor, la expressión y la significación en música se aproximan al juego simbólico y la organización es un juego de regla” (DELALANDE, 1995, p. 16).

${ }^{132}$ Esther Thelen (1941-2004) foi psicóloga, cientista cognitivista e professora da Universidade de Indiana (EUA) e presidiu a Sociedade Internacional para Estudos Infantis, entre 1996 e 1998.
} 
“[...] reconhece a presença, a necessidade e a importância dos padrões, considerando-os não como estruturas a priori, mas, sim, como emergentes no trânsito do corpo com o ambiente". Apesar de Thelen e Smith ${ }^{133}$ terem partido das pesquisas de Piaget, as autoras foram além delas, por considerarem que ele não havia superado o problema do dualismo mente/corpo quando postulou um plano progressivo e linear do desenvolvimento infantil (da ação sensóriomotora, de uma inteligência concreta para um nível de abstração mental sofisticado). Ainda segundo Brito:

Piaget considerou uma evolução que seguia da experiência corporal, da percepção e da ação, para um nível de manipulação puramente simbólica, aspecto no qual reside o dualismo com o qual Thelen discorda. O que Piaget propõe como passagem de um nível a outro deve ser entendido, na hipótese dinamicista de Esther Thelen, como aumento da complexidade: como acréscimo no número de partes e de atividades diferentes, bem como nas relações entre elas (BRITO, 2007, p. 74).

A partir dessas ideias, pode-se observar que o processo de criação de Arthur foi se complexificando à medida que ele foi incorporando e mesclando sons, imagens e histórias.

\section{Processo de criação da música "O gigante"}

Depois de um tempo razoável explorando as possibilidades sonoras da harpa do piano, Arthur fez um glissando ascendente nas cordas, começando na mais grave e terminando na última corda desse grupo. Percebi que o resultado sonoro o encantou, e ele repetiu o movimento várias vezes, alterando velocidade, intensidade e duração, acionando por mais ou menos tempo o pedal $3 \mathrm{C}$.

Passado um tempo, interferi e propus a ele que inventasse uma música com o efeito sonoro que tanto o encantara. Arthur rapidamente aceitou a ideia e, decidido, disse que queria tocar "três glissandos mais rápidos e um mais longo", estendendo assim, a duração do último glissando com a colocação do pedal 3C (para esclarecer: tomando-se a semínima como pulso, o resultado sonoro foi de três semínimas e uma mínima). Ao ouvir a execução, comentou que os primeiros eram "os passos do gigante" e o último glissando (a mínima) era um "prédio sendo pisoteado por ele" (16min10s - 16min19s). Logo em seguida, tocou o motivo

\footnotetext{
${ }^{133}$ Linda Smith é professora e pesquisadora do departamento de Psicologia da Universidade de Indiana (EUA). Publicou com Esther Thielen o livro A Dynamic Systems Approach to the Development of Cognition and Action. Cambridge, Massachusetts: The MIT Press, 1994.
} 
acrescentando mais três glissandos, em metade do bloco das cordas, e disse: "são os passos do gigante de novo, mas agora em cima de casas e não de prédios" (16min20s - 16min24s). Perguntei a ele por que estava tocando o glissando só até a metade do grupo de cordas e ele me respondeu: “ué, eu já não falei que eram casas, e não prédios?”.

O glissando nas cordas graves fez surgir a imagem de passos de um gigante, o que desencadeou o resto da pequena história de Arthur, fazendo-o procurar no piano os sons para contá-la. Na verdade, não foi possível distinguir se o som remetia à imagem ou se a imagem buscava o som, parecendo se tratar de um processo simultâneo.

Minutos depois dos "passos do gigante sobre as casas", Arthur se levantou, foi para o teclado e fez alguns testes, aprovando uma segunda ascendente com as notas sol e lá mais agudas do piano (16min27s) para a chegada "de um porquinho muito pequeno, que se assustou com o gigante que tentou esmagá-lo, mas correu muito depressa". Depois de outras experimentações, escolheu um glissando ascendente por todo o teclado para o porquinho correndo (16min29s - 16min33s). Para finalizar, a volta aos três passos iniciais do gigante (três semínimas, tomando-a como pulso), consolado ou não com a fuga do porquinho (16min34s - 16min36s).

Arthur ficou muito contente com sua criação e a repetiu muitas vezes, ao longo daquele ano. As palavras de Brito descrevem muito bem aqueles momentos de Arthur: "A criança é um ser 'brincante' e, brincando, faz música, pois assim se relaciona com o mundo que descobre a cada dia" (BRITO, 2003, p. 35). Posso afirmar que essa composição teve grande significado para Arthur, que, quando a tocava, "transformava-se em sons", tomando de empréstimo a expressão de Brito.

$\mathrm{Na}$ análise do vídeo e de todo o processo aqui descrito, um aspecto me chamou a atenção: a singularidade de cada criança em seu processo de aprendizado. Arthur é uma criança de imaginação extremamente fecunda e adora inventar e contar histórias, sentindo às vezes uma verdadeira necessidade de fazê-lo. Ele vai espontaneamente do piano para o desenho de um personagem, ou do personagem para a música, ou mesmo da música para a dramatização.

Arthur é meu aluno desde 2012 até os dias atuais, no ano de 2014, e sempre demonstrou muita alegria em voar nas asas de sua imaginação, chegando a sofrer quando seus 
companheiros não compartilham de seus voos. Destaco esse aspecto de sua personalidade para situar a música "O gigante" nesse contexto de fantasia e imaginação. Contudo, é importante ressaltar que, ao longo de quase dois anos de contato com Arthur, venho observando suas idas e vindas para o mundo de outras fantasias, próprias dos meninos grandes. Essas mudanças refletiram nas aulas de piano, propiciando também a possibilidade de descobertas técnicas e conhecimentos que levaram a uma compreensão mais intelectual, sem perder a imaginação e a criatividade, tão preciosas em Arthur. No entanto, logo nas primeiras aulas, decidi respeitar sua individualidade e propor um primeiro contato com o instrumento que permitisse o espaço da criação, conectado com outras formas de expressão dramatização, histórias, desenhos etc. -, pois percebi que imaginar e criar eram as formas mais produtivas de se chegar a um aprendizado significativo para ele. Fundamento essa decisão nas considerações de Gainza, que afirma que o objetivo principal de todo professor deve ser a conexão com a "natureza profunda e com as necessidades de desenvolvimento de seus alunos" (GAINZA, [s.d.]) através da música, e também de Brito, que aponta para uma educação musical que considere a criança em primeiro plano, não a música:

Mais do que meramente pretender ensinar música, nosso propósito é escutar e respeitar o processo de reinvenção de cada criança, caminhando juntos com ela e, assim redimensionando e ampliando as experiências e os conhecimentos (BRITO, 2007, p. 70).

Essa concepção de educação musical orienta pedagógica e musicalmente as aulas de Arthur, pois uma observação atenta e afetuosa determinou, desde o princípio, que seus voos devem ser contemplados para que ele consiga tocar piano de forma significativa.

\section{"Ideia musical"}

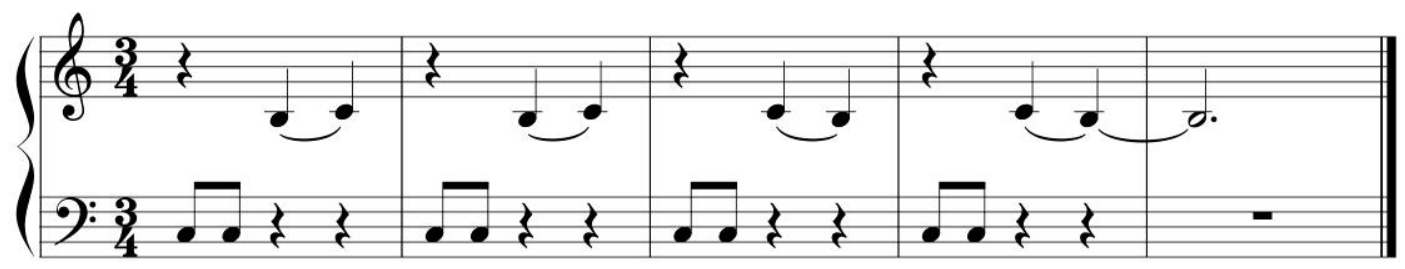




\section{O diálogo e algumas reflexões}

A pequena frase musical acima foi inventada por Arthur, quando ele esperava, sozinho na sala, sua aula começar. Do lado de fora, ouvi que ele já tinha tocado várias vezes a mesma frase; esperei por alguns minutos e, quando percebi que ele parara de tocar, entrei na sala. Segue o pequeno diálogo que se deu, então:

Professora: Oi, Arthur! O que você tá tocando?

Arthur: Ah! Só uma ideia.

Professora: Toca pra mim?

Arthur: Tá

Então, Arthur tocou.

Professora: Muito legal, essa sua ideia. É uma ideia musical, né?

Arthur: É... - pensou um pouco. - Uma ideia musical.

De acordo com o dicionário Aurélio, a palavra ideia significa "representação mental que o espírito forma de qualquer coisa". Já o dicionário Priberam define ideia como "representação que se forma no espírito", e o dicionário Michaellis, "representação mental de uma coisa concreta ou abstrata". Mas o que significaria ideia para Arthur?

Esse pequeno diálogo e a pergunta não feita me fizeram pensar muito, e cheguei a outra questão: por que nós, professores, falamos tanto em sala de aula e disponibilizamos tão pouco espaço para perguntas, sejam dos professores aos alunos ou dos alunos aos professores? Não seria, ainda, resquício de uma educação herdada de séculos atrás, da qual a premissa "professor ensina, aluno aprende" ressoa em nossos ouvidos? Seria a constante preocupação de passar todos os conteúdos que dedicadamente selecionamos para a aula? Ou falta de interesse em ouvir o que eles têm a nos dizer, por acreditarmos que temos muito mais a dizer a eles do que eles a nós? Talvez todas essas as respostas estejam corretas, pois nossa atuação em sala de aula ainda é permeada por ideias de educação cristalizadas há séculos e, mesmo que busquemos transformar a relação triádica professor-aluno-conhecimento, ainda esbarramos em posturas automatizadas em nossa rotina educacional. Precisamos aprender a estar presentes, atentos, disponíveis para ouvir e cautelosos para falar, pois muitos de nós não vivemos esse modelo de educação quando alunos, nem em nossa formação pedagógico-musical. 
Koellreutter (1997d, p. 41) pensava que não adiantaria reformular programas de ensino se não se transformasse a didática e a metodologia, e, por consequência, a atuação do professor e a própria relação professor-aluno. Ele afirmava que, no contexto educacional habitual, o professor só se preocupa em "transmitir conhecimentos herdados" e, geralmente, de forma "fastidiosa". No entanto, na realidade educacional pensada por ele, denominada ensino prefigurativo, o professor "orienta, guia o aluno" e sempre o incita a questionar, a pensar, a conscientizar-se: "o professor não ensina nada; ele sempre conscientiza". Buscar esse professor prefigurativo exige disponibilidade à transformação e a uma outra concepção do que é ser professor. Essa nova concepção de ensino e professor se aproxima da reflexão de Rocha:

Pois o professor é o mestre dos encontros - mais do que aquele que ensina. ${ }^{134}$ Talvez, no campo da arte na educação, especialmente em se tratando das artes cênicas e da música, possamos dizer uma espécie de mestre de cerimônias. Que apresenta os personagens e introduz ou levanta os temas, incita a conversa - mais do que enuncia seu próprio discurso -, intermedia os conflitos e cuida para que a atmosfera seja segura, acolhedora e estimulante. É necessário que proporcionemos aos nossos alunos a oportunidade dos encontros e que os acompanhemos no movimento da experiência que pode vir a acontecer. A criança pode se encantar, por exemplo, pela descoberta de uma sonoridade interessante na exploração de um material - acolher essa descoberta, colocá-la como se sob um foco, uma lente, ampliando-a, incentivar sua manipulação, variações e articulações é o trabalho de um professor (ROCHA, 2011, p. 48).

Seria desejável estar em sala de aula como esse mestre que promove encontros entre a criança e a música, a criança e ela mesma, e a criança e nós, professores. Essa postura tem que ser construída, é preciso estar totalmente imerso no contexto da aula e, ao mesmo tempo, à parte, para observar e saber o momento ideal de intervir.

Vários recursos podem ser preciosos nesse exercício de constante avaliação do processo educacional. Registros, sejam de vídeo ou áudio, fotográficos ou simplesmente anotações de aula, podem auxiliar muito essa observação refinada, podendo ser ferramentas muito úteis para a autoavaliação do professor e para ampliar a percepção de detalhes que escapam durante a aula. É como ver com uma lupa cada fala, cada som, cada expressão; perceber a falta de uma possível pergunta, uma frase desnecessária ou uma intervenção acertada. Como diz a psicopedagoga e educadora musical Márcia Lagua Oliveira: "Mediados por nossos registros, tecemos o processo de apropriação de nossa história, tanto no nível

134 Expressão usada pelo prof. Hélio Rebello, na mesa-redonda Inconsciente, Aprendizado, Educação: contribuições de Deleuze e Guattari. 26 de junho de 2008, FE Unicamp [nota do original]. 
individual quanto coletivo. Nesse caminho, podemos voltar ao passado, enquanto construímos nossas marcas no presente, nossa história" (OLIVEIRA, 2009, p. 22). Enfim, aprender com o registro e caminhar para a transformação.

Assim, o registro em vídeo de Arthur possibilitou muitas reflexões e constatações. É possível perceber sua intensa reação corporal aos sons produzidos, como quando externa a percepção da duração da última nota de "Ideia musical": ele sente a vibração e reage balançando o corpo em círculos como a própria onda sonora (17min46s - 17min49s) - um pequeno detalhe que eu não percebi in loco, mas, registrado em vídeo, possibilitou-me observar melhor as percepções e reações de Arthur. Ver e rever o vídeo da aula disparou descobertas, surpresas e reflexões, como bem expressa Márcia Lagua:

Ao ler e reler a documentação de registro, pequenas anotações, rascunhos, fotos, desenhos nos deparamos com descobertas, com novas dimensões que surgem da apreensão de um gesto numa foto, nos surpreendemos com uma única palavra que se destaca em meio a tantas outras de um texto. O mundo compartilhado é o solo de nossos encontros com o outro, espaço onde nossas histórias se revelam, assim como nossas ações, decisões e envolvimentos (OLIVEIRA, 2009, p. 42).

\section{A ideia}

Destaco do diálogo com Arthur sua resposta à pergunta sobre o que estava tocando: “Ah! Só uma ideia”, não uma música ou mesmo "não é nada não", como já dissera em outras ocasiões.

De acordo com o Dicionário Grove de Música (1994, p. 624), motivo é "uma ideia musical curta, podendo ser melódica, harmônica ou rítmica, ou as três simultaneamente. Independente de seu tamanho, é geralmente encarado como a menor subdivisão com identidade própria de um tema ou frase”. Koellreutter (1990, p. 90) define a mesma palavra como "unidade estrutural elementar melódica e/ou rítmica com duração correspondente a duas ou três unidades de tempo". A partir dessas definições, identificamos na ideia de Arthur o motivo melódico-rítmico que gerou a frase musical. 


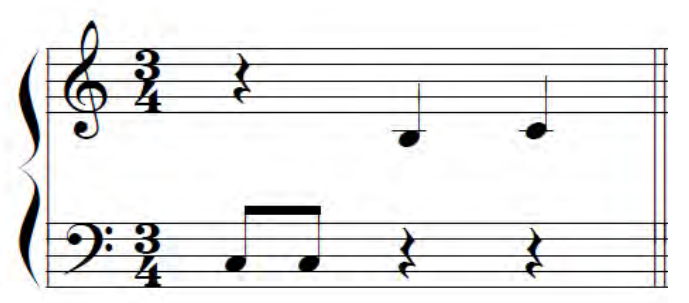

Arthur desenvolve sinteticamente essa ideia melódica-rítmica, repetindo-a e invertendo-a (apenas a segunda menor), criando uma frase musical. Sendo um motivo uma ideia musical curta ou uma unidade estrutural, Arthur teve uma percepção exata do que fez. Sua fala $(21 \min 37 \mathrm{~s}-21 \min 43 \mathrm{~s})$ demonstra que ele sabia, mesmo que intuitivamente, o que havia inventado:

Professora: Tem nome já essa música, não?

Arthur: Não! É só uma ideia, quem disse que era uma música?

Tocando descomprometidamente, deslizando os dedos sobre as teclas sem uma intenção predeterminada, Arthur criou o motivo. E descreve seu processo de forma muito simples $(17 \min 53 \mathrm{~s}-18 \mathrm{~min} 07 \mathrm{~s})$ :

Professora: Eu gostaria de saber como surgiu essa ideia?

Arthur: Oh! Como surgiu essa ideia? Como todas as outras: tocando uma nota, tocando outra, tocando outra, até chegar em uma ideia.

Sua explicação revela a total integração de seu fazer e seu pensamento musical, expresso nesse pequeno motivo. No contato diário com crianças, é possível observar que essa inteireza sempre está presente, principalmente, nas crianças menores. Infelizmente, com o passar dos anos, vamos nos impregnando dessa forma desconectada e fragmentada de se relacionar com tudo e com todos. Felizmente, Arthur, com 8 para 9 anos, ainda apresenta essa ligação entre corpo e mente, fazer e pensar, sem se contagiar pelo dualismo ainda tão presente nos contextos educacionais. Ressalto, mais uma vez, a importância de se criar espaços agenciadores dessas conexões para que as crianças transitem por essas formas de lidar com o ambiente e com os objetos do conhecimento. Brito (2007, p. 70) nos alerta para como a interação com o ambiente muda o fazer musical das crianças, muitas vezes agregando novas possibilidades e novos conhecimentos, mas às vezes com "limitações decorrentes de territorializações que tendem a maiorizar os modos de fazer e considerar a música", entendendo-se maiorizar como imposição de modos consolidados do fazer musical. 


\section{A performance}

Arthur é espontaneamente uma criança performática. Sua aula é repleta de personagens, desenhos, sons, músicas e dramatizações, como já citado anteriormente. Ele se encanta quando gravamos a aula em vídeo e sempre sugere que o façamos como numa entrevista, na qual, por decisão dele, assume o papel de pianista e compositor, e eu, o de repórter; ele indica, inclusive, o tipo de programa: uma entrevista (17min) ou um anúncio de uma filmagem (16min03s), entre outros. Ao perceber como era importante deixá-lo transitar livremente entre as diversas expressões, entrei no jogo de seu imaginário.

Nas reflexões de Beineke (2011, p. 102), é possível notar a importância que a pesquisadora dá para o que as crianças pensam sobre música em relação às práticas sociais e como elas relacionam o que fazem em sala de aula com o que vivenciam no dia a dia. Essa aproximação entre o cotidiano e a aula não se dá só pelo repertório, mas pela forma como se apresenta o fazer musical para os outros, que, muitas vezes, se parece com o que as crianças concebem como uma apresentação musical, como as que veem na televisão, em shows ou em filmes. Essas situações dão significado às atividades de aula, como no caso de Arthur, que insistia em gravar os vídeos incorporando o personagem de um pianista que é entrevistado em um programa de televisão.

Foi muito fácil acolher e me encantar com a singularidade e a criatividade de Arthur, mas, ao lado de seus tão saudáveis devaneios artísticos, foi importante ajudá-lo a aceitar formas de lidar com o objeto do conhecimento que não abarcassem o mundo da fantasia, tão precioso para ele. Muitas vezes, diante das dificuldades inerentes ao estudo de qualquer instrumento musical, ele queria desistir, por exigir persistência para se alcançar determinados resultados pianísticos. Encontrar várias maneiras de se aproximar da música, num verdadeiro caldeirão musical, tem sido a solução para conquistar Arthur e outros alunos. As ideias de Gainza demonstram que há muitas formas de se aprender um instrumento musical:

Eu estou convencida de que a maneira de aprender qualquer coisa é aprendê-la de muitas maneiras, ao mesmo tempo. Essa é minha fórmula: Aprender a aprender implica aprender de muitas maneiras. Uma forma seria escutando, outra, lendo, outra, observando e imitando. Muitas vezes, funciona aquela velha e tradicional forma do professor que diz: "Olha, eu faço assim"135 (GAINZA, 2002, p. 122, tradução nossa, grifo do original).

\footnotetext{
135 "Yo estoy convencida de que la manera de aprender cualquier cosa es aprenderla al mismo tiempo de muchas maneras. Ésa es mi fórmula: Aprender a aprender implica aprender de muchas maneras. Una forma sería escuchando; otra, leyendo; otra, e imitando. Muchas vezes funciona aquella vieja y tradicional forma del profesor que dice: 'Mira, hazlo así'” (GAINZA, 2002, p. 122).
} 
Complementando a afirmação de Gainza com a de Oliveira (2009, p. 162): “[...] na tarefa de aprender ou apreender a realidade, precisamos transitar pelos caminhos da imaginação, da ilusão, da desilusão, do conflito, do repouso e da criação". Arthur, em sua aula de piano, caminha por esses caminhos e, a partir deles, vai construindo sua própria trajetória musical.

\section{Registros musicais}

No trabalho musical desenvolvido com Arthur, usamos diversos tipos de notação musical, inclusive a introdução à escrita tradicional, selecionando uma ou outra de acordo com os parâmetros mais significativos de cada música. Algumas dessas notações eram:

- símbolos criados por ele mesmo;

- símbolos próximos ao gesto (por exemplo: o raspar da baqueta nas cordas do piano era representado por um rabisco em zigue-zague);

- números correspondentes às teclas usadas para tocar determinada melodia;

- nomes das notas e ritmo da melodia só de memória;

- escrita dos nomes das notas com pequenos traços e pontos para indicar o ritmo;

- notas escritas em escadinhas, representando o movimento sonoro ascendente e descendente;

- notas representadas em duas ou três linhas, de acordo com o necessário;

- notas no pentagrama, mas sem as figuras de duração.

Para que Arthur apreendesse a notação musical significativamente, não só como um código decorado e sonoramente vazio, a opção foi a diversidade de notações. Só incorporamos a escrita tradicional às aulas quando ele se mostrou motivado a aprendê-la, e a partir de uma melodia com alturas e durações bem definidas, como é o caso de "Ideia musical".

Pedro Paulo Salles, músico e prof. dr. da USP, desenvolveu um trabalho sobre o uso de várias notações musicais no processo de construção musical da criança que aponta a importância da criação de notações pelas próprias crianças e critica a imposição da escrita tradicional sem qualquer construção de significado (SALLES, 1996, p. 151-152). 
A partir da história da notação musical na música ocidental e de exemplos de outras culturas e diferentes formas de registro, Salles nos instiga a pensar sobre essa questão na educação musical:

Se aprendemos com a história que momentos diferentes, necessidades diferentes, culturas diferentes e ambientes sonoros diferentes geraram músicas e notações igualmente diferentes, nas quais o conceito de precisão, por exemplo, era totalmente outro, devemos nos perguntar sobre a aplicação de notação musical no trabalho em educação musical com crianças, considerando as especificidades desse trabalho e a natureza das relações da criança com músicas e sons (SALLES, 1996, p. 153).

Outra afirmação do mesmo autor apresenta a ideia da notação como processo em constante transformação, conectada às necessidades que demandam do próprio fazer musical:

[...] a notação nunca está definitivamente pronta enquanto código. Ela se transforma em adaptações constantes às demandas da composição, da percepção, da prática musical e da compreensão e construção de conceitos; ela se transforma também em função das demandas históricas e sociais de cada grupo, seja àquelas relativas à faixa etária ou época histórica, seja às relativas à sua cultura ou modo de produção. É a evolução coordenada destes fatores que permite a articulação dos possíveis em necessários, ou seja, que a experiência se torne sistema [...] (SALLES, 1996, p. 179, grifos do original).

Campos (2000) também apresenta reflexões valiosas em relação a essa questão, detalhando as etapas de aprendizado que passam por diversas formas de notação e fundamentando tal prática num pensamento construtivista-interacionista que tem a expressão musical do aluno como objetivo central.

A pianista defende que o professor deve evitar a cristalização de práticas oriundas de aprendizados opostos: de um lado, aprender a tocar apenas de ouvido, do outro, só por leitura. Se a introdução da leitura não se fizer "dentro da polaridade sensorial e racional, algum bloqueio pode acontecer", mas "se essas duas maneiras de praticar música forem introduzidas sob o sentido de complementaridade entre si, sendo assim valorizadas pelo professor, o aluno obterá naturalidade e liberdade" (CAMPOS, 2000, p. 157).

Campos também relativiza a importância dada à introdução da leitura tradicional logo nos primeiros contatos do aluno com o instrumento, indicando similaridades com o processo da aquisição da fala, no qual o aprendizado da leitura e da escrita da língua só acontecem depois de alguns anos. A autora se refere às culturas de tradição oral, em que a escrita de música não é tão importante quanto no mundo ocidental. Cita Cage quando ele "comenta 
sobre a Índia, dizendo que lá a ação musical é direta, a partir dos ouvidos, sem a interposição dos olhos" (CAGE, $1985^{136}$ apud CAMPOS, 2000, p. 158).

A autora sugere a livre improvisação como ponto de partida para a codificação, defendendo que o primeiro passo para se compreender o significado da escrita musical deveria ser um registro impreciso e não convencional:

Seria como uma prévia de qualquer leitura detalhista. Os sons são pesquisados, vivenciados e sentidos para em seguida serem estruturados, e só então registrados através da escrita, cujos símbolos são criados para atender da maneira mais precisa possível. Acabam sendo eles quase sempre muito pouco convencionais, de acordo com os desenhos sonoros que são também nada convencionais (CAMPOS, 2000, p. 159).

Campos (2000, p. 162) ainda destaca que a escrita criada a partir das improvisações, para a qual frequentemente se precisa de uma bula, aproxima-se da grafia contemporânea e afirma que o contato com diferentes grafias desde o começo do estudo do instrumento pode evitar bloqueios futuros do aluno ao se deparar com outros tipos de leitura.

Para fundamentar a ideia de se partir do global para o específico no processo da leitura musical, a autora cita Ostrower (1978), que discorre sobre processos de percepção, destacando as ordenações de campo, nas quais "nosso modo de relacionar sempre se procederá de grandeza maior para menor, para um estado específico focal" (OSTROWER, 1978, p. 89, grifos do original). Assim, leitura e escrita não convencionais, com símbolos e sinais criados pelo próprio aluno para registrar sua improvisação, são da ordem do geral e devem ser praticadas anteriormente à leitura e à escrita tradicional, que são focais, com alturas e durações determinadas e específicas. Campos não despreza o conhecimento da grafia e da leitura musical tradicional, reconhecendo sua importância para o aprendizado musical do aluno, se respeitado o momento certo de introduzi-lo:

Depois dessa escrita [não convencional] é que deve ser introduzida a leitura tradicional, também de maneira global, ou seja, registrando os sons de todo o teclado, ao mesmo tempo, numa enorme pauta. As crianças acham interessante compreender a grafia de todos os sons do piano, do mais grave ao mais agudo. Se partimos do dó 3 poderemos introduzir as notas nas duas claves, em sentido invertido (como num espelho), em movimento contrário tanto sonoro quanto visual. A necessidade das duas claves, das linhas e espaços suplementares e linhas de oitava será compreendida de imediato [...]. A memorização, após perceber a lógica do movimento dos sons e sua escrita, será trabalhada com objetivo de fixação de notas em ambas as claves, através de associações gráficas e intervalares [...]. Quanto ao ritmo, a natureza deve ser o ponto de partida [...], os sons do cotidiano, a

${ }^{136}$ CAGE, J. De segunda a um ano. São Paulo: Hucitec, 1985. 
regularidade neles presente pode sugerir um início de conversa sobre o ritmo, presente em tudo, de maneira regular ou irregular. Em seguida, a própria ideia musical do aluno pode ser o início do trabalho rítmico. Pela observação do pulso e das durações que ocorreram na improvisação ou composição, podemos começar o trabalho rítmico (CAMPOS, 2000, p. 163164).

Campos (2000, p. 164) considera que a leitura de cifras deve ser introduzida no estudo do piano "o mais cedo possível, juntamente com o trabalho de escalas, música 'tirada de ouvido’ e transposição". Também sugere que se parta do pentacorde e se pratique em todos os tons, tocando tríades sobre todas as notas das escalas, e que o professor "chame a atenção do aluno para ouvir tudo que está sendo pesquisado. O ouvido deve vir sempre em primeiro lugar, mesmo no momento em que procuramos compreender teoricamente o que está sendo estudado" (grifos do original). Por fim, a autora conclui que "o importante é o iniciante tomar a maior consciência possível, criando relações entre o auditivo, o teórico e seu registro" (CAMPOS, 2000, p. 165).

François Delalande (1995) já apontava um caminho pedagógico similar ao de Moema Craveiro Campos, defendendo, inclusive, que no início do aprendizado musical pode-se até nem incluir notações morfológicas muito precisas, ${ }^{137}$ priorizando trabalhos que estimulem a curiosidade e propiciem um grande leque de possibilidades musicais às crianças, permitindo que elas mesmas criem seus registros. Delalande ainda afirma que o registro escrito nem sempre é necessário e faz alusão ao grande número de músicas do mundo que se transmitem sem partitura (DELALANDE, 1995, p. 127-128). O autor aconselha que se adote uma convenção de acordo com cada música:

Ao escolher determinada notação, coloca-se ênfase em um ponto de vista. Mas se numa vez anotam-se as intervenções, noutra, as alturas, noutra, o brilho harmônico ou qualquer particularidade morfológica, não se arrisca a escolher [notações] automaticamente. $\mathrm{Na}$ verdade, a única solução prejudicial seria escolher, de uma vez por todas, uma convenção morfológica e mantê-la durante todo o ano. Nesse caso, a notação tem um efeito simplificador e empobrecedor irreversível. Quando a música se reduz, pouco a pouco, a uma caricatura ${ }^{138}$ (DELALANDE, 1995, p. 129-130, tradução nossa).

\footnotetext{
${ }^{137}$ Delalande usa a expressão notaciones demasiado precisas para se referir principalmente à precisão de alturas e durações da escrita tradicional.

138 “Cada elección de notación pone el acanto sobre un punto de vista. Pero, si usted anota una vez las intervenciones, otra vez las alturas, otra, el brillo armónico o cualquier particularidad morfológica, no se arriesga a crear esos automatismos de filtración. En el fondo, la única solución que puede resultar verdaderamente perjucial, consiste en elegir una vez por todas una convención morfológica y manternela durante todo el año. Es en ese caso, cuando la notación tiene un efecto simplificador y empobrecedor irreversible. Cuando la música se reduce, poco a poco, a una caricatura" (DELALANDE, 1995, p. 129-130).
} 
Violeta de Gainza complementa a posição adotada por Delalande abordando motivação e real necessidade como parâmetros para a introdução da escrita tradicional. Com base nas abordagens criativas do ensino de um instrumento, ela defende que leitura e escrita devem ser introduzidas quando o aluno estiver motivado e sentir necessidade de aprendê-la, podendo, assim, escrever quando quiser registrar uma invenção, ou ler quando precisar (GAINZA, 2002, p. 112).

Nas minhas aulas, venho buscando diversificar ao máximo as possibilidades do fazer musical no piano, possibilitando também diferentes formas de registro. Muitas vezes, a necessidade ou o desejo de aprender a escrita tradicional surgem ao ouvir um colega tocar ou ao acompanhar a audição de uma música na partitura. Assim como Gainza, Campos reitera que a necessidade ou o desejo de aprender surgem gradualmente e consistem no principal motivador do aprendizado: "Há um aprender contínuo na percepção aguda dos mínimos contatos, um transformar que absorve gradualmente mudanças que associam novidades à vontade de aprender. Na verdade, nada se ensina, aprende-se pelo momento de interesse ou pelo grau da necessidade" (CAMPOS, 2000, p. 19).

Por fim, considero que a sugestão de se criarem notações a partir das necessidades das composições dos alunos, presente no artigo de Salles (1996), a confirmação na citação de Delalande (1995) e as ideias de Campos (2000) justificam o interesse da descrição das diferentes partituras que Arthur criou para "Ideia musical".

\section{As partituras de Arthur}

"Ideia musical" foi uma ótima oportunidade para Arthur avançar na apropriação da escrita tradicional, pois o motivo melódico-rítmico que criara tinha só três notas e ritmo muito simples. Por isso, depois de muitas execuções, propus três desafios de notação, como ele mesmo explicou "um desafio com três níveis, feito [o] de um videogame" (18min07s). A seguir, apresento as propostas:

(1) Partitura com números de teclas: a primeira proposta feita a Arthur foi escrever "Ideia musical" como quisesse, com a condição de que o registro fosse claro o suficiente para que qualquer pessoa pudesse decifrá-lo, inclusive ele, na aula seguinte, caso não lembrasse de memória. Disse-lhe que a partitura deveria funcionar como registro do que ele tocou. Arthur 
optou por uma forma que usávamos bastante: desenhávamos um teclado e colocávamos números nas teclas na sequência que eram tocadas, o ritmo era tocado de memória. Para ele, "foi simples, eu fiz como números", e apontou a partitura, começando a cantar e seguindo-a com os dedos (18min22s - 18min40s):

$$
1 \text { e } 2 \text { - dó } 2 \quad 3 \text {-si } 3 \quad 4 \text { - dó } 3
$$

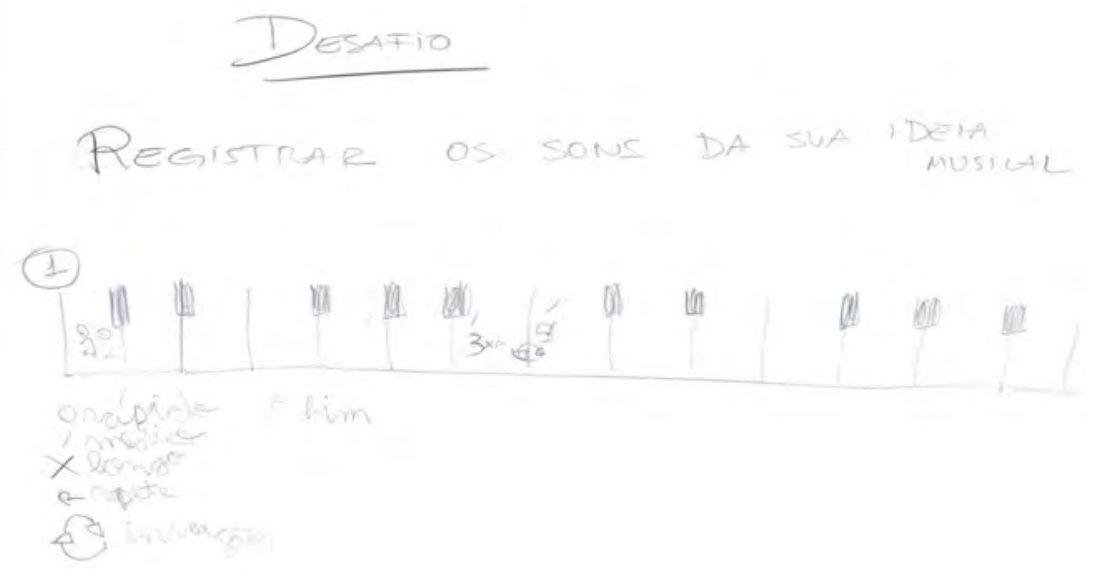

Nota-se que Arthur ampliou a notação a que estava acostumado e acrescentou o registro do ritmo usando símbolos. Apesar de as durações serem precisas na execução - um pulso, sua subdivisão binária e o dobro do pulso -, Arthur usou palavras imprecisas para representá-las: rápido, médio e longo. Essa imprecisão não o incomodou, o que demonstra que a exatidão do tempo na notação não era significativa para ele naquele momento; sua relativa definição dos tempos em palavras lhe era suficiente, pois ele sabia de memória o ritmo da melodia que queria tocar $(18 \min 55 \mathrm{~s}-19 \min 42 \mathrm{~s})$ :

$$
\begin{gathered}
00 \text { - rápido } \\
\text { / - médio } \\
\mathrm{X} \text { - longo }
\end{gathered}
$$

Por fim, Arthur também usou letras e sinais para os seguintes comandos:

$$
\begin{aligned}
\mathrm{R} & - \text { repete } \\
\mathrm{F} & - \text { fim } \\
\text { setas } & - \text { inversão das notas } \\
& \text { na terceira repetição }
\end{aligned}
$$

Duas setas em um círculo indicam a inversão da segunda menor ascendente (si - dó), tocada pela mão direita, para uma segunda menor descendente (dó - si), na terceira e na quarta repetição (19min14s). Percebe-se que Arthur tinha consciência da inversão, de tal forma que não escreveu simplesmente as notas na ordem invertida, mas fez um sinal para 
indicá-la. No vídeo, nota-se sua percepção ao associar a inversão da figura melódica a uma brincadeira de coordenação das mãos do seu cotidiano (19min18s - 19min30s).

Segundo Ostrower, a memória ordena os processos que vivemos com base em associações, e essas compõem a essência de nosso mundo imaginativo:

A consciência se amplia para as mais complexas formas de inteligência associativa, empreendendo seus voos através de espaços em crescente desdobramento, pelos múltiplos e concomitantes passados-presentes-futuros que se mobilizam em cada uma de nossas vivências (OSTROWER, 1978, p. 19).

Não lembramos apenas de fatos isolados, temos lembranças interligadas, assim, a memória sempre se amplia e se reconfigura com novas associações. Essas associações nos conduzem para o mundo da fantasia, que não é necessariamente devaneio ou fantástico, e geram "um mundo experimental, de um pensar e agir em hipóteses - do que seria possível, nem sempre provável” (OSTROWER, 1978, p. 20).

A imaginação de Arthur está sempre a postos, voando de um ponto a outro, de um foco único para o todo e do todo para um foco. E é assim que ele aprende. Como já disse antes, acolher não só as muitas ideias que ele trazia para aula, mas também sua forma de se relacionar com o aprendizado e, a partir disso, desenvolver o estudo musical foi uma escolha que eu, como professora, fiz na nossa primeira aula. Era preciso dar-lhe voz não só para registrar sua música, como também para conscientizá-lo de seus próprios processos e aprendizados, como fazemos no vídeo, quando conversamos sobre suas partituras e como ele as havia elaborado.

Burnard (2004, p. 32) defende que, para desenvolver uma prática criativa, é essencial compartilhar ideias e possibilitar discussões que considerem a visão dos alunos sobre sua própria aprendizagem. A autora também aponta que:

A percepção de que o professor será um modelo poderoso e facilitador, pensando sobre o aprendizado, é importante para habilitar e dar suporte ao aprendizado, tanto no ambiente pessoal como no escolar. Também é importante aceitar que, apesar de a abordagem mais comum (como as baseadas em teorias sociais construtivistas) ser aquela em que o professor ensina o aprendiz a aprender, na verdade, as aulas serão ocupadas com falas e com alunos aprendendo uns com os outros. Compreender o ponto de vista do aluno sobre o aprendizado, onde quer que apareça, e permitir que isso 
aconteça talvez sejam uma das mais difíceis lições que os professores têm a aprender ${ }^{139}$ (BURNARD, 2004, p. 32, tradução nossa).

Beineke (2009, p.103) também considera que a reflexão, o debate de ideias e a discussão de suas ações podem promover um aprendizado mais significativo:

[...] a aprendizagem criativa é potencializada em atividades musicais que não apenas promovam a realização criativa - caso das composições musicais das crianças - mas que também incentivem a análise e a reflexão sobre as práticas musicais da turma. Nesse processo - quando as crianças têm a oportunidade de falar sobre a maneira como compreendem a música e atribuem significados em sala de aula, em conjunto com a professora - é favorecida a construção coletiva de conhecimentos.

Embora as pesquisadoras se refiram a contextos de aulas em grupo, a ideia de promover um fazer reflexivo, evidenciando as diferentes formas de pensar sobre o próprio aprendizado e tornando-o mais significativo e efetivo, pode ser bastante valioso. Assim, se um aprendizado instrumental acontecer num espaço onde os alunos tenham voz e façam música pensando sobre isso, eles provavelmente terão um conhecimento mais integrado, sem dualismo entre teoria e prática, e uma expressão musical mais autêntica.

(2) Partitura com nome de notas: a segunda proposta de notação sugerida a Arthur foi a de registrar a música com os nomes das notas, indicando as durações. Não determinei como ele deveria fazê-lo, como ocupar o espaço da folha ou quais sinais usar.

Ele fez duas linhas horizontais e dividiu o espaço entre as regiões grave, média e aguda, colocando a inicial dessas palavras no lugar determinado. Na primeira linha, escreveu as notas do primeiro compasso, que é tocado duas vezes, na segunda linha, as notas do terceiro compasso, também tocado duas vezes, com a duração da última nota (SI) prolongada na repetição.

\footnotetext{
139 "The realization that the teacher will be a powerful model for, and the facilitator of, thinking about learning is important in enabling and supporting learning in both classroom and personal loci. Also important is the acceptance that although the most common approach taken (as based on social constructivist theories) is one in which the teacher teaches the learner how to learn, the reality is that classrooms will be busy with talk and with learners learning from each other. Coming to understand pupils' views on learning, wherever it occurs, and allowing this to happen, may be one of the hardest lessons pre-service and practicing teachers have to learn" (BURNARD, 2004, p. 32).
} 


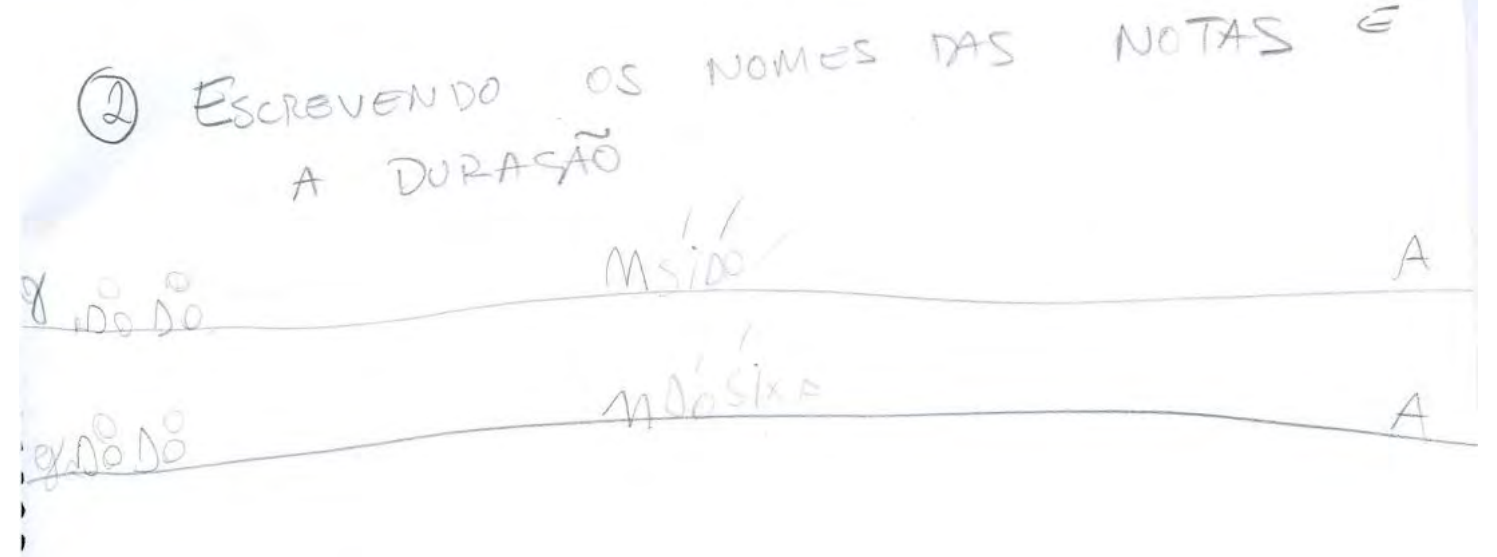

Para indicar as durações, Arthur usou os mesmos sinais da partitura com números. Ao explicar o que fizera, disse que usou "as mesmas regras", aparentemente se referindo tanto às durações como às próprias notas, pois apontava para a partitura e cantava a melodia, não só as durações (19min53s - 20min05s).

Ao ser indagado sobre a diferença de código que ele usou em relação às alturas, Arthur concordou que os sinais para as durações foram os mesmos e indicou a sua divisão por região: "Era assim: G, grave, médio, agudo" (19min45s - 19min50s). Chamei sua atenção para mostrar que ele usara uma nova forma de registro das alturas em relação à primeira partitura e perguntei como ele pensara, a resposta foi: "Fácil! Grave, mi... grave, médio, agudo". Insisti que era mais do que isso, que ele tinha escrito o nome das notas, e ele concordou: "Foi isso, sim" (20min11s - 20min22s). Apesar de ter concordado com minha insistente afirmação de que a escrita dos nomes das notas era mais precisa do que só a região, para Arthur, a diferença entre as duas partituras não eram os nomes das notas, mas a indicação das regiões, essa era a novidade que acrescentara ao registro.

O território da precisão implica adentrar no universo da técnica, da busca de conhecimentos específicos e especializados, detalhando, analisando, codificando e decodificando e, enfim, agregando variáveis que tornam mais complexa a experiência. Interagir com os processos precisos de estruturação musical é, em nosso caso, consequente ao ambiente em que estão inseridas as crianças (BRITO, 2007, p. 86).

Encontro similaridade entre a afirmação de Brito e a experiência de Arthur. O exercício de registrar fielmente sua ideia musical, que tinha alturas e durações precisas, lhe permitiu se apropriar de alguns conhecimentos e sistematizá-los, complexificando sua experiência. Naquele momento, ele se aproximava dos "territórios da precisão", mas respeitou-se a singularidade de seu pensamento musical em construção. 
(3) Partitura no pentagrama: o último desafio proposto a Arthur foi registrar sua ideia musical no pentagrama. Em aulas anteriores, ele já se familiarizara com a pauta musical escrevendo melodias curtas, sem figuras de duração ou fórmula de compasso, mas com as claves, e ouvindo músicas que acompanhávamos seguindo a partitura.

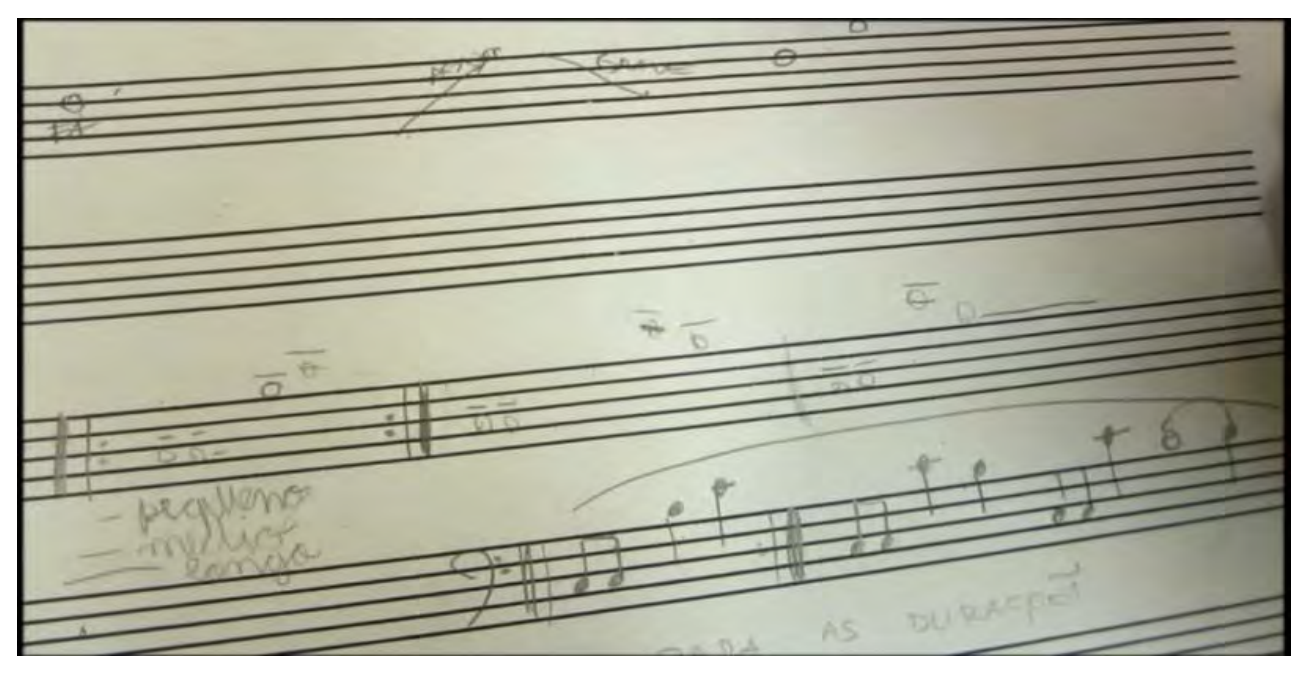

Ouvir CDs acompanhando a partitura é um recurso bastante habitual nas minhas aulas de piano com o objetivo de aproximar os alunos da escrita tradicional a partir de uma forma de leitura global. Ela serve como um roteiro no qual as crianças identificam com certa facilidade a correspondência entre o desenho gráfico das notas com os eventos sonoros, como: o contorno dos desenhos melódicos com o movimento sonoro ascendente e descendente, a sobreposição das notas nos acordes ou clusters com blocos sonoros, uma grande densidade sonora com muitas figuras e pouca densidade com poucas figuras etc. A criança se aproxima da leitura sem saber o que exatamente significa cada sinal, mas começando a relacionar o que ouve e o que vê.

Arthur estava nesse momento do processo em relação à escrita tradicional: já conhecia as claves, a relação dos movimentos sonoros com o movimento das figuras no pentagrama e os sinais que representavam as durações, mas ainda não se apropriara totalmente desses conhecimentos. Nesse contexto, escreveu as notas em seus respectivos lugares no pentagrama usando a clave de fá, mas para indicar as durações preferiu usar seu próprio código. No vídeo, ele explica: "Eu fiz novos processos: pequeno, médio, longo", apontando os traços que determinou para as durações $(20 \min 29 \mathrm{~s}-20 \min 35 \mathrm{~s})$. Destaco aqui a tranquilidade de Arthur 
ao pensar em outra possibilidade de notação para as durações, os "novos processos". Nas duas primeiras partituras, ele usou os seguintes sinais para os sons longos, médios e curtos:

$$
\begin{aligned}
00 & \text { - "rápido" } \\
\text { / } & \text { - médio } \\
\mathbf{X} & - \text { longo }
\end{aligned}
$$

Na última partitura, mudou os sinais para:

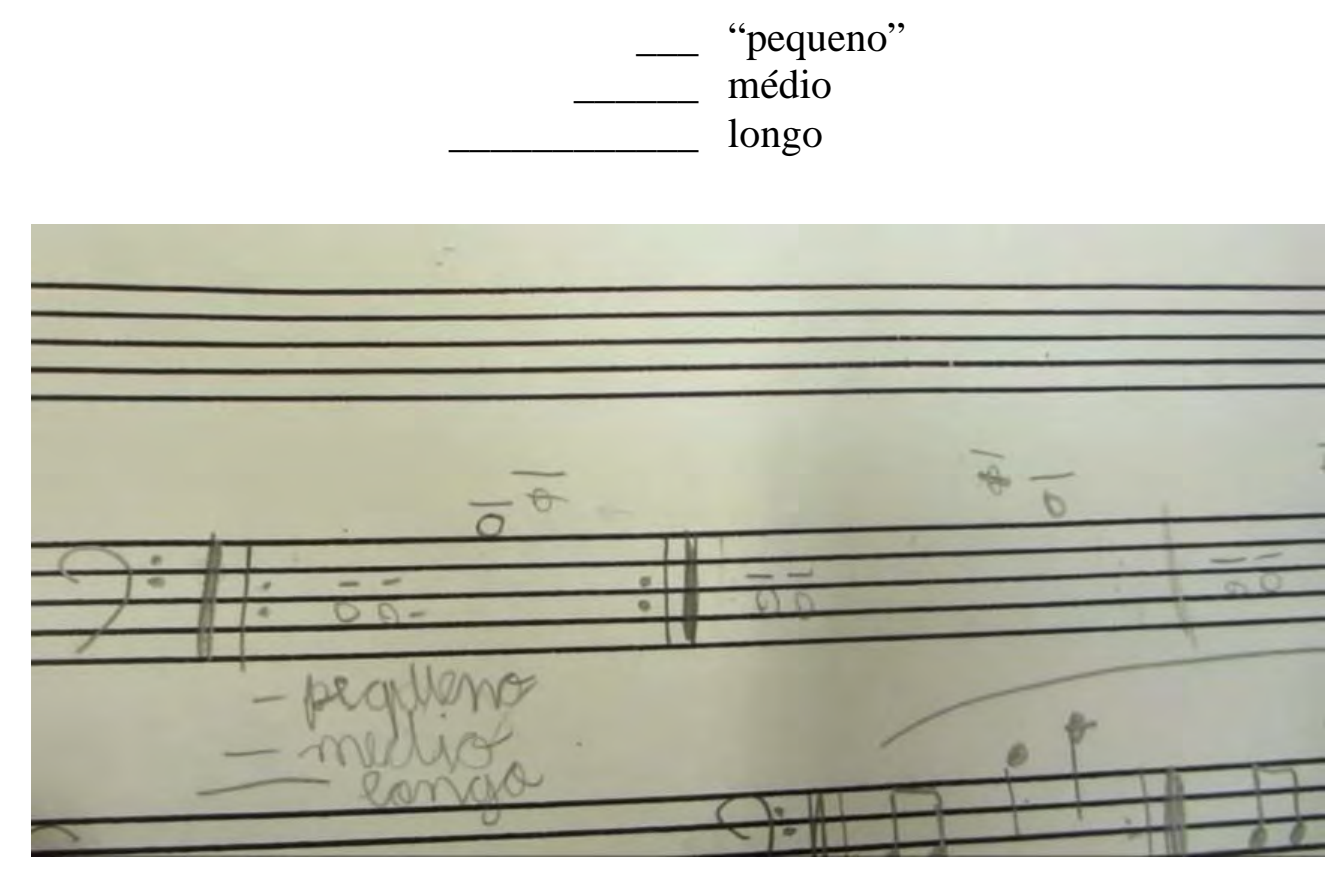

As palavras rápido e pequeno estão entre aspas pois são as denominações de Arthur para os sons curtos. A precisão da notação da duração não era tão relevante para ele, nesse momento. Sendo o papel do professor acolher o que o aluno propõe e, gradualmente, abrir possibilidades para seu conhecimento crescer e se estruturar a partir da prática e da reflexão, procurei agir dessa forma. Um exemplo disso é o registro das durações, depois da terceira fase da escrita: escrevemos usando as figuras de duração que ele já conhecia, mas deixando sempre claro que era só uma possibilidade dentre outras que ele mesmo criou. Assim, reforça-se o entendimento da função da escrita como registro do que é tocado e ouvido e se estimula uma postura mais flexível diante das diversas possibilidades de escrita musical, já que ele mesmo criou diferentes notações para um mesmo elemento.

O pensamento de Delalande em relação às notações no processo educacional afirma a importância de colocar a escrita em sua real posição e de estar aberto às diferentes possibilidades de notação, de acordo com o que seja necessário no momento da aula: 
O olho e a construção intelectual não devem substituir a escuta e a sensibilidade. O papel não é mais que um auxiliar da memória. Mas não entenda essas propostas como regras invioláveis. O dia em que você precisar chamar a atenção sobre a altura, fará partituras de altura e terá razão ${ }^{140}$ (DELALANDE, 1995, p. 128, tradução nossa).

Na EMIA, não aplicamos provas, mas fazemos avaliações constantes a cada aula, observando o aluno e seu desenvolvimento musical ao longo do ano. Alguns professores adotam a estratégia de avaliação conjunta de aluno e professor, no final do ano ou do semestre. Para verificar o quanto Arthur já tinha se apropriado do mecanismo da escrita no pentagrama, iniciei esse pequeno diálogo $(20 \min 37 \mathrm{~s}-21 \mathrm{~min} 27 \mathrm{~s})$ :

Professora: ... E pra saber se é dó, si, você usou o quê?

Arthur: Ah! Clave de fá.

Professora: E aí? Como você descobriu onde era o dó se a clave mostra só o fá?

Ele respondeu seguro, apontando a quarta linha:

Arthur: Se aqui é o fá, aqui deve ser... pera aí... aqui é o fá, aqui é o mi, ré, dó.

Professora: Humm... indo pro grave. Indo pro agudo, se aqui é o fá, como eu cheguei no si?

Novamente com segurança, ele respondeu:

Arthur: Fácil! É só ir fá, sol, lá, si e depois é dó.

Professora: E agora eu tô vendo aqui uma coisa, com essas figuras...

Eu me referia às figuras de duração que usamos, pois, partindo de sua notação, reescrevemos sua música com as figuras de duração no pentagrama, de acordo com a convenção da escrita tradicional. Mas Arthur entendeu que eu estava me referindo ao ritornello que ele havia grafado na partitura pois já conhecia o sinal:

Arthur: Que significa que tem que repetir, mas só pode repetir duas vezes. Mais de duas, tem que escrever normal.

No fim da conversa $(21 \mathrm{~min} 28 \mathrm{~s}-21 \mathrm{~min} 42 \mathrm{~s})$, perguntei se ele queria falar alguma coisa para terminar a entrevista:

Professora: Então, uma despedida? Com a música de novo ou não?

Arthur: Ah! Se os créditos forem com essa música, aceito.

\footnotetext{
140 "El ojo y la construction intellectual no deben reemplazar la escucha y la sensibilidad. El papel no es más que un auxiliary de la memoria, Pero no tome estas propuestas como reglas inviolables. El día que usted necesite llamar la atención sobre la atura, hará partituras de altura y tendrá razón" (DELALANDE, 1995, p. 128).
} 
Professora: Tem nome já essa música ou não?

Arthur: Não. É só uma ideia! Quem disse que é uma música?

É encantador observar o caminho que Arthur foi trilhando aula a aula. Suas descobertas, suas conquistas pianísticas, seus aprendizados. Aprender a escrita tradicional é muito gratificante, pois, como diz Campos (2000, p. 162), "no âmbito da educação musical, não saber ler é como ser cego, fechado para as belezas que a música, ao longo se sua história nos oferece". No entanto, é imprescindível lembrar que fazer música não é só ler, como afirma Paynter (1972, p. 9, tradução nossa): "Música não é colcheias e semínimas. Não são pontos sobre o papel: são sons" ${ }^{141}$ Por muito tempo, o ensino de piano ficou restrito à leitura de partituras e exercícios técnicos, mas é preciso ir além, não desprezar a técnica e o repertório escrito, mas ampliá-los, conjugando-os com outras possibilidades.

Para finalizar, tomo de empréstimo as palavras de Brito:

As crianças fazem música sonorizando sensações, percepções, pensamentos... regidos (ainda) pela unidade, pelo todo, pelo sonoro. A experimentação se sobrepõe à técnica dirigida. Fazer música é uma questão de vontade, de desejo, de conquista. Música que é potência de vontade, que aciona, também, o detalhar, a técnica. Com muitas e outras possibilidades, no entanto, para além daquelas que as alturas e durações definidas permitem construir (BRITO, 2007, p. 83).

141 “Music is not quavers and crochets. It's not dots on the paper: It's sounds" (PAYNTER, 1972, p. 9). 


\section{CONSIDERAÇÕES FINAIS}

É preciso aprender a navegar em oceanos de incertezas em meio a arquipélagos de certeza.

Edgar Morin

Diversos questionamentos surgidos dos trabalhos de educação musical com as crianças me levaram a esta pesquisa.

Da década de 1970, quando comecei a estudar piano, até o fim da década de 1980, quando comecei a dar aulas para uma criança de 6 anos, observei poucas transformações pedagógicas. No entanto, após os primeiros anos de imersão no cotidiano da sala de aula, a necessidade de mudanças se fez premente. A busca por novas abordagens de educação musical me fez refletir também sobre minha abordagem pianística. Uma questão presente nesta dissertação surgia: por que o espaço para a criação não fazia parte da maioria dos métodos e das práticas dos professores de piano? Dessa, surgiram outras questões sobre princípios que poderiam fundamentar uma prática mais criativa e aspectos relacionados com o pensamento musical das crianças. Esse questionamento norteou esta pesquisa.

No início, retomei sinteticamente a história do piano no Brasil e fiz uma revisão sucinta dos métodos publicados e incorporados pela pedagogia pianística brasileira. Nessa primeira parte, foi possível observar que, se, por um lado, muitos dos pilares que fundamentaram o ensino de piano no século XIX continuam presentes em muitos métodos para piano, por outro, ao longo do século XX, novas abordagens foram surgindo e apontando em direção a um aprendizado mais criativo. Mesmo apresentando grandes diferenças entre eles, a análise dos onze livros para piano selecionados confirmou a possibilidade de se inserir um espaço criativo nas aulas de piano, indo contra a tendência comum de adotar métodos e livros que, embora apresentem linguagem e design mais modernos, seguem os mesmos princípios do ensino tradicional dos métodos da primeira metade do século XX: aquisição da escrita tradicional e desenvolvimento das habilidades técnicas. Exemplo disso são os métodos de Leila Fletcher e mesmo de John Thompson, muito frequentes nas aulas de piano no Brasil.

Em busca de referenciais teóricos que fundamentassem e reafirmassem a importância de propostas que estimulam a criatividade nas aulas de piano, destaquei aspectos do pensamento de alguns educadores musicais e constatei que, mesmo em tempo e países diferentes, além de áreas específicas de atuação profissional, há muitos pontos de convergência entre eles. Hans-Joachim Koellreutter e Violeta Hemsy de Gainza, grandes 
mestres, apontam a criação como aspecto fundamental na educação musical. Ambos tecem críticas ao ensino tradicional de música, que prioriza habilidades técnicas e de leitura da escrita tradicional, focado num repertório limitado, sem espaço para a criação. É importante destacar que os autores não negligenciam esses aspectos na formação do estudante, mas criticam a redução do ensino musical a eles.

Dentre as diversas conexões entre o pensamento de Koellreutter e Gainza, destaco a valorização da integração entre o fazer e o pensar, estabelecendo uma relação contínua entre os dois, e a concepção da música como experiência multidimensional transformadora que contribui para a expansão da consciência humana. A improvisação como recurso para possibilitar o desenvolvimento da criatividade e a apropriação de conceitos musicais é fundamental nas duas propostas.

Os dois educadores também olham para o século XX (e o XXI, no caso de Gainza) como uma época de grandes mudanças que determinaram a urgente necessidade de transformar a concepção de educação musical e a própria ação pedagógica do educador, que deverá ser mais um guia, um possibilitador, do que um professor no sentido usual do termo, com olhos e ouvidos atentos à singularidade do aluno.

Dialogando com eles, as ideias de Moema Craveiro Campos e Maria Teresa Alencar de Brito surgem como ramificações de um mesmo pensar, mas com personalidade própria. Ambas foram alunas de Koellreutter e foram influenciadas por Gainza. Voltada para o ensino de piano inserido no contexto da educação musical, Campos encontra na filosofia de Aurobindo, na psicologia de Rogers e Jung, nas descobertas da física quântica, no movimento da arte-educação e nas ideias de Paynter e Aston um leque de ideias que fundamentam sua concepção de uma nova pedagogia pianística. Como um caminho que pode levar a uma execução musical mais expressiva e prazerosa, a autora aponta a exploração das diversas possibilidades sonoras do instrumento, o estímulo à relação afetiva do aluno com o instrumento por meio do foco no interesse do aluno, diversas modalidades de improvisação e a harmonia prática, associados à aprendizagem tradicional.

Brito defende uma educação musical que, entre outros aspectos, considere as ideias de música das crianças em toda sua singularidade e espontaneidade. A partir da longa experiência com crianças em aulas de música, do contato com o mestre e amigo Koellreutter, das referências deleuzianas e da teoria dinamicista de Thelen, Brito compõe um corpo de ideias sobre crianças e músicas. Encontrei muitos pontos de diálogo entre suas concepções e as dos outros educadores apresentados nesta dissertação, como: a valorização do espaço 
criativo em todos os contextos de educação musical, a necessária mudança da postura do professor para que se instale um ambiente de parceria e coautoria dos acontecimentos sonoromusicais nas aulas, a valorização da observação e da reflexão por parte do professor, a concepção de que a música é uma das formas de manifestação da consciência etc. Contudo, entendo que a grande contribuição de Brito se encontra no centro de seu trabalho e é o respeito e o olhar atento à singularidade do fazer musical das crianças, transcendendo o próprio objetivo de se ensinar música. É importante ressaltar que transcender não significa suprimir e sim incorporar e ir além. Trilhar esse caminho com a criança, respeitando suas ideias de música, é fundamental para Brito.

Finalizando o corpus de referências teóricas, as pesquisas de Viviane Beineke e de Anna Craft, Teresa Cremmin, Pamela Burnard e Bob Jeffrey sobre aprendizagem criativa e possibility thinking corroboraram com as ideias de Koellreutter, Gainza, Brito e Campos, sendo que diversos aspectos apontados por essas pesquisas já estavam presentes nos pensamentos dos educadores citados anteriormente. Possibility thinking, isto é, o pensamento que opera com diversas possibilidades, considerado o âmago da aprendizagem criativa pelas pesquisadoras inglesas, e as orientações para que a criatividade possa emergir nos contextos educacionais, como "aproveitar o inesperado sem perder de vista o objetivo original, fazer perguntas abertas, encorajar ideias abertas e reflexões críticas e rever, regularmente, o trabalho em andamento" (CREMIN; BURNARD; CRAFT, 2006), apresentam total sintonia com a ideia de pedagogia aberta de Gainza e com as orientações de Koellreutter sobre a postura do professor como orientador, que faz perguntas mais do que dá respostas. Também é possível encontrar conexão com a pedagogia pianística de Campos e a proposta de educação musical de Brito.

Beineke (2009) e Burnard (2004) também dialogam com Brito (2007) quando ressaltam a importância de escutar e acolher a voz das crianças, respeitando sua singularidade no fazer musical.

É importante ressaltar que, embora essas vozes estejam afinadas em diversos aspectos, principalmente na valorização do espaço criativo na educação musical, creio que seja preciso transformar ainda mais amplamente o ensino de música, pois a educação musical ainda carrega princípios e condutas de um passado que precisamos transcender, como dizia Koellreutter.

Os primeiros capítulos foram imprescindíveis para construir a reflexão pedagógico-musical das composições dos alunos que desenvolvi no terceiro capítulo. O olhar para as 
produções das crianças e a escuta de suas ideias sobre seu fazer musical, iluminados pela pesquisa anterior, constituíram a essência do trabalho.

Voltam as primeiras questões relacionadas ao protagonismo e ao pensamento musical das crianças. Questões inter-relacionadas demandam respostas interconectadas que formam uma verdadeira trama. Os relatos de experiência apresentados apontam possíveis caminhos, mais do que respostas.

Destaco as explorações sonoras e as improvisações de Beatriz, Laura e Arthur. O encantamento disparado por cordas, martelos, pedais, teclas e muitas sonoridades indica uma possibilidade de aproximação do piano, criando maior intimidade e afetividade com o instrumento. Campos (2000) defende como uma das prioridades do ensino pianístico buscar essa intimidade e liberdade descompromissada para que o piano possa realmente ser usado como um instrumentum, isto é, "um meio, um objeto ou recurso para alcançar um objetivo" (DICIONÁRIO DO AURÉLIO). Nesse caso, o objetivo é a expressão musical.

Outro aspecto desenvolvido com a pesquisa sonora no instrumento foi a percepção e a consciência dos elementos sonoro-musicais. Durante as explorações sonoras e as improvisações, as crianças foram se apropriando de conceitos musicais como os parâmetros sonoros, densidade, forma, tempo métrico e não métrico etc. Ampliou-se também o repertório sonoro e, por consequência, as possibilidades do fazer musical, transcendendo o sistema tonal que emerge quase que espontaneamente da configuração do teclado.

É possível que, se desde o início do contato com o instrumento oferecermos às crianças uma gama de possibilidades para se fazer música, propiciaremos uma escuta mais aberta às produções musicais que não se enquadram no tonalismo, como as da segunda metade do século XX e outras tantas que compõem a grande diversidade cultural do mundo. O século XXI nos permite viajar virtualmente por lugares que nem poderíamos imaginar décadas atrás, proporcionando-nos o conhecimento de culturas e suas músicas que, muitas vezes, colocam em questão o próprio conceito que temos de música. Como diz Brito (2007, p.14), é importante apontar "a coexistência de ideias de música em tempos e espaços próximos ou distantes, [...] [músicas que] desvelam o humano [...], ambientes, culturas e consciências, em dinâmicos processos de reorganização".

Em relação às improvisações e às composições, ressalto sua importância como meio de apropriação da linguagem musical e como recurso para avaliação do conhecimento do aluno de piano. A análise dos vídeos com os depoimentos e a produção musical das crianças 
confirmou essa percepção empírica. Dos vários exemplos, destaco a descoberta do cromatismo como conceito, desdobrando-se em exercícios técnicos, conhecimento teórico e como ideia disparadora da composição de Laura, as escolhas intuitivas e conscientes na construção da composição de Beatriz, reveladoras de sua apropriação da sintaxe musical, e as partituras de Arthur e seu depoimento que demonstra seu caminho na construção do registro musical, inclusive da escrita tradicional.

A reflexão pedagógico-musical sobre os processos criativos de Beatriz, Laura e Arthur proporcionou também a identificação de possíveis caminhos para a condução de um espaço agenciador da criação musical. Digo possíveis caminhos por considerar que a singularidade do fazer musical de cada um deles norteou, em grande parte, o caminho que trilhamos. É preciso respeitar a singularidade e a iniciativa do aluno, proporcionar espaço e tempo para que as ideias musicais surjam e possam ser desenvolvidas, para que se reconheça a técnica como ferramenta para conseguir o resultado pretendido, para que o fazer musical dispare o aprendizado dos conceitos teóricos, para tocar o que se inventou, o que se imitou, o que se tirou de ouvido, o que se aprendeu lendo uma partitura, para que a música possa, enfim, acontecer na sala de aula.

Deve-se construir esse espaço agenciador do encontro professor-música-aluno. No entanto, sabemos que não é tarefa fácil. Exige de nós, professores, uma presença que reconheça os momentos de observar ou de propor, de recuar ou desafiar, de calar ou intervir, de receber e de dar. É preciso construir o conhecimento musical com o aluno e, antes de mais nada, fazer música com ele. Ainda, citando Brito (2007, p. 246):

Assim também pensamos os planos de Educação: movimentos que disparam
linhas de fuga aos mecanismos de controle [...] fundados no respeito, no
compartilhar, no prazer, na vontade de conhecer, no afeto, no amor, na
capacidade de criar, recriar, criticar... Juntos e sempre em movimento.

Por fim, como uma pesquisa qualitativa, estas reflexões procuram contribuir com a educação musical, buscando novas possibilidades de fazer música e favorecer uma relação professor e aluno para que haja um encontro significativo e criativo com o piano.

Como disse muitas vezes Koellreutter: "o que importa é jogar sua pedra no lago", não importando tanto seu tamanho, mas o movimento que produz. 


\section{REFERÊNCIAS}

ALENCAR, E. S.; FLEITH, D. S. Criatividade: múltiplas perspectivas. 3. ed. Brasília: Editora Universidade de Brasília, 2009.

AMATO, R. C. F. Funções, representações e valorações do piano no Brasil: um itinerário sócio-histórico. Revista do Conservatório de Música da UFPel, Pelotas, v. 1, n. 1, p. 166-194, 2008.

Educação pianística: o rigor pedagógico dos conservatórios. Música Hodie, v. 6, n. 1, p. 75-96, 2006.

ANDRADE, M. Pianolatria. Klaxon: Mensário de Arte Moderna, São Paulo: Martins, n. 1, 15 maio 1922. Brasiliana Digital. Disponível em:

<http://www.brasiliana.usp.br/bbd/bitstream/handle/1918/01005510/010055-

1_COMPLETO.pdf>. Acesso em: 6 jan. 2014.

ATTA MÍDIA E EDUCAÇÃO. Edgar Morin. Apresentação Edgard de Assis Carvalho e participação especial de Edgar Morin. Produção: ATTA Mídia e Educação, [s.d.]. 1 DVD. (Coleção Grandes Pensadores.)

BAILEY, D. Improvisation: its nature and practice in music. Ashborune: Moorland Pub./Incus Records, c.1980.

BARBOSA, D. Cacilda Borges Barbosa, [s.d.a.]. Disponível em: <http://denisbarbosa.addr.com/cbbbio.pdf>. Acesso em: 24 abr. 2014.

. Cacilda Borges Barbosa, [s.d.b.]. Disponível em:

<http://dbpedia.org/page/Cacilda_Borges_Barbosa>. Acesso em: 24 abr. 2014.

BEINEKE, V. Aprendizagem criativa e educação musical: trajetórias de pesquisa e perspectivas educacionais. Educação, Santa Maria, v. 37, n. 1, p. 45-60, 2012.

. Aprendizagem criativa na escola: um olhar para a perspectiva das crianças sobre suas práticas musicais. Revista da ABEM, Londrina, v. 19, n. 26, p. 92-104, jul./dez. 2011.

. Processos intersubjetivos na composição musical de crianças: um estudo sobre a aprendizagem criativa. Tese (Doutorado em Música) - Instituto de Artes, Universidade Federal do Rio Grande do Sul, Porto Alegre, 2009.

. A composição no ensino de música: perspectivas de pesquisa e tendências atuais.

Revista da ABEM, Porto Alegre, v. 20, p. 19-32, set. 2008.

. A composição em sala de aula: como ouvir as músicas que as crianças fazem? In:

HENTSHKE, L.; SOUZA, J. (Orgs.). Avaliação em música: reflexões e práticas. São Paulo: Moderna, 2003. cap. 7, p. 91-105.

BERLINER, P. F. Thinking in jazz: the infinite art of improvisation. Chicago: The University of Chicago Press, 1994. 
BIOGRAFÍA de Violeta Hemsy de Gainza. Violeta Hensy de Gainza, 30 jun. 2008. Disponível em: <http://www.violetadegainza.com.ar/2008/06/biografia-de-violetahemsy-de-gainza/\#more-9>. Acesso em: 25 jun. 2014.

BOJÉ, H. Klavierschule für Anfänger. Viena: Universal/Stuttgart: Ernst Klett Verlag, 1982.

BRESLER, L. Pesquisa qualitativa em educação musical: contextos, características e possibilidades. Revista da ABEM, Porto Alegre, v. 16, p. 7-16, mar. 2007.

BRITO, M. T. A. Ferramentas com brinquedos: a caixa da música. Revista da ABEM, Porto Alegre, v. 24, p. 89-93, set. 2010.

Por uma educação musical do pensamento: educação musical menor. Revista da ABEM, Porto Alegre, v. 21, 25-34, mar. 2009.

. Por uma educação musical do pensamento: novas estratégias de comunicação.

Tese (Doutorado em Comunicação e Semiótica) - Pontifícia Universidade Católica de São Paulo, São Paulo, 2007.

. Gesto/ação/pensamento musical: o fazer musical da infância. In: ENCONTRO ANUAL DA ASSOCIAÇÃO BRASILEIRA DE EDUCAÇÃ̃O, 14., 2005, Belo Horizonte. Anais. Belo Horizonte: Abem, 2005. 1 CD-ROM.

. Criar e comunicar um novo mundo: as ideias de música de H. J. Koellreutter. Dissertação (Mestrado em Comunicação e Semiótica) - Pontifícia Universidade Católica de São Paulo, 2004.

. Música na educação infantil: propostas para a formação integral da criança. São Paulo: Peirópolis, 2003.

. Koellreutter educador: o humano como objetivo da educação musical. São Paulo: Peirópolis, 2001.

BURNARD, P. Researching Musical Creativities in Practice, 2012. Disponível em: <http://vimeo.com/39665461>. Acesso em: 10 jul. 2014.

. Pupil-teacher conceptions and the challenge of learning: lessons from a Year 8 music classroom. Improving Schools, v. 7, n. 1, p. 23-34, mar. 2004.

. How Children Ascribe Meaning to Improvisation and Composition: rethinking pedagogy in music education. Music Education Research, v. 2, n. 1, 2000.

CABEZAS, H. C. Considerações sobre os horizontes pedagógicos em Játékok, de György Kurtág. In: JORNADA ACADÊMICA DISCENTE PPGMUS/USP, 1., São Paulo. Anais... Disponível em:

<http://www3.eca.usp.br/sites/default/files/form/ata/pos/ppgmus/helena_cabezaseducacao.pdf $>$. Acesso em: 16 dez. 2012.

CAMPOS, M. C. A educação musical e o novo paradigma. Rio de Janeiro: Enelivros, 2000. 
CORVISIER, F. G. M. Antônio de Sá Pereira e o ensino moderno de piano: pioneirismo na pedagogia pianística brasileira. Tese (Doutorado em Música) - Escola de Comunicação e Artes, Universidade de São Paulo, São Paulo, 2009.

COSTA, R. L. M. A livre improvisação musical e a filosofia de Gilles Deleuze. Per Musi, Belo Horizonte, n. 26, p. 60-66, 2012.

. A ideia de jogo em obras de John Cage e no ambiente da livre improvisação. Per Musi, Belo Horizonte, n. 19, p. 83-90, 2009.

. O músico enquanto meio e os territórios da livre improvisação. Tese (Doutorado em Comunicação e Semiótica) - Pontifícia Universidade Católica, São Paulo, 2003.

. Suite improviso: a construção da improvisação, composição e interpretação em práticas interativas. Dissertação (Mestrado em Musicologia) - Escola de Comunicações e Artes, Universidade de São Paulo, São Paulo, 2000.

CRAFT, A. Creativity and Education Futures: learning in a digital age. Stoke-on-Trenth: Trentham Books, 2011.

CREMIN, T.; BURNARD, P.; CRAFT, A. Pedagogy and possibility thinking in the early years. Thinking Skills and Creativity, n. 1, p. 108-119, 2006. Disponível em: <http://www.sciencedirect.com/science/article/pii/S1871187106000290>. Acesso em: 2 abr. 2013.

CUMMINGS, D. (Ed.). The Hutchinson Encyclopedia of Music. Oxford: Helicon/BBC Music Maganize, 1995.

CSIKSZENTMIHALYI, M. Creativity. Nova York: Harper Collins, 1996.

DELALANDE, F. La música es un juego de niños. Buenos Aires: Ricordi Americana, 1995.

DELEUZE, G.; GUATTARI, F. Mil platôs: capitalismo e esquizofrenia. Rio de Janeiro: Editora 34, 1995. Introdução: Rizoma. v. 1.

DELORS, J. (Org.). Educação: um tesouro a descobrir. Relatório para a UNESCO da Comissão Internacional sobre Educação para o século XXI. Brasília: Cortez, 1999.

DICIONÁRIO Cravo Albin da Música Popular Brasileira. Rio de Janeiro: Instituto Cultural Cravo Albim. Disponível em: <http://www.dicionariompb.com.br/>. Acesso em: 18 jun. 2014.

DICIONÁRIO DO AURÉLIO. Disponível em:

<http://www.dicionariodoaurelio.com/Composicao.html>. Acesso em: 2 ago. 2013.

DICIONÁRIO GROVE DE MÚSICA. Ed. concisa. Editado por Stanley Sadie. Rio de Janeiro: Jorge Zahar, 1994.

DICIONÁRIO MICHAELLIS. São Paulo: Melhoramentos, 2009. Disponível em: <http://michaelis.uol.com.br/>. Acesso em: 2 ago. 2013. 
DICIONÁRIO PRIBERAM DA LÍNGUA PORTUGUESA. Disponível em: <http://www.priberam.pt/DLPO/>. Acesso em: 2 ago. 2013.

DICIONÁRIO HOUAISS ELETRÔNICO DA LÍNGUA PORTUGUESA. Instituto Antônio Houaiss. Rio de Janeiro: Objetiva, 2009. 1 CD-ROOM.

EDITORAÇÃO de partituras. SOUZA REIS. Disponível em: <http://souzareiseditoracaodepartituras.blogspot.com.br/2009/09/piano-2-arranjos-eatividades-2009-ana.html>. Acesso em: 25 jun. 2014.

ERNST WIDMER. Academia Brasileira de Música, [s.d.a]. Disponível em: <http://www.abmusica.org.br/html/sucessor/sucessor31.html>. Acesso em: 25 jun. 2014.

. Suíços do Brasil, [s.d.b]. Disponível em:

<http://www.suicosdobrasil.com.br/biografias/ernst.widmer.html>. Acesso em: 25 jun. 2014.

ESPERIDIÃO, N. Educação musical e formação de professores: suíte e variações sobre o tema. São Paulo: Globus, 2012.

. Conservatórios: currículos e programas sob novas diretrizes. Dissertação (Mestrado em Música) - Instituto de Artes, Universidade Estadual Paulista Júlio de Mesquita Filho, São Paulo, 2003.

FERNANDES, J. N. Educação musical: temas selecionados. Curitiba: CRV, 2013.

FONTERRADA, M. T. O. Taller de creacion y escucha del paisaje sonoro (entrevista). La Casa Encendida. Madri: Fundación Caja Madrid, 2014a. Disponível em: <https://www.lacasaencendida.es/page/id-1-1143-0-102075-438433-102076-0.go>. Acesso em: 10 jan. 2014.

Currículo Lattes, 9 abr. 2014b. Disponível em: <http://lattes.cnpq.br/3530066753313245>. Acesso em: 10 jan. 2014.

De tramas e fios: um ensaio sobre a música e educação. São Paulo: UNESP, 2005. ; PASCOAL, M. L. Sons da infância. São Paulo: Novas Metas, 1979.

FONTOURA, F. Atenção: crianças compondo. Porto Alegre: Metrópole, 1993.

FRANÇA, C. C.; SWANWICK, K. Composição, apreciação e performance na educação musical: teoria, pesquisa e prática. Em Pauta, v. 13, n. 21, p. 5-41, dez. 2002.

GADOTTI, M. Desafios para a era do conhecimento, 2006. Disponível em: <http://www.adur-rj.org.br/5com/pop-up/desafios_era_conhecimento.htm>. Acesso em: 15 jul. 2014.

GAINZA, V. H. El rescate de la pedagogía musical: conferencias, escritos, entrevistas. Buenos Aires: Lumen, 2013. 
GAINZA, V. H. Sobre la creatividad y el vínculo con la música. In: BENENZON, R. (Org.); GAINZA, V. H.; WAGNER, G. (Colaboradoras). La nueva musicoterapia. 2. ed. Buenos Aires/México: Lumen, 2008.

En musica in dependencia: educación y crisis social. Violeta Hemsy Gainza e Pepa Vivanco. Buenos Aires: Lumen, 2007.

La improvisación musical, 2005a. Disponível em:

<http://www.violetadegainza.com.ar/2005/06/la-improvisacion-musical/> . Acesso em: 15 abr. 2014.

. A jugar y cantar con el piano, 2005b. Disponível em:

<http://www.violetadegainza.com.ar/2005/06/a-jugar-y-cantar-con-el-piano/>. Acesso em: 15 abr. 2014.

Pedagogía musical: dos décadas de pensamiento y acción educativa. Buenos Aires: Lumen, 2002.

Problemática actual y perspectivas de la educación musical para el siglo XXI. Lima: Pontifícia Universidad Católica del Peru, 2000.

. Método para piano: introducción a la música. Tomo I. Buenos Aires: Barry, 1998.

Palitos chinos. Buenos Aires: Barry, 1987.

. A improvisação musical como técnica pedagógica. Atravez Associação Artístico Musical, [s.d.]. Disponível em:

<http://www.atravez.org.br/ceem_1/improvisacao_musical.htm>. Acesso em: 25.jul. 2014.

GALLO, S. Deleuze e a educação. Belo Horizonte: Autêntica, 2003.

GONÇALVES, M. L. J. Educação musical através do teclado: etapa de musicalização, manual do professor, v. 1. 3. ed. Rio de Janeiro: [s.n.], 1989.

; BARBOSA, C. B. Educação musical através do teclado: musicalização, v. 1. 5. ed. Rio de Janeiro: [s.n.], 1986.

; BARBOSA, C. B. Ensino de piano em grupo no Brasil: etapa de leitura, [s.d.a].

Disponível em: <http://www.pianoemgrupo.mus.br/manual03.htm>. Acesso em: 22

nov. 2013.

; BARBOSA, C. B. Ensino de piano em grupo no Brasil: etapa de desenvolvimento da musicalidade, [s.d.b]. Disponível em:

<http://www.pianoemgrupo.mus.br/manual03.htm>. Acesso em: 22 nov. 2013.

; BARBOSA, C. B. Ensino de piano em grupo no Brasil: quem é Maria de Lourdes, [s.d.c]. Disponível em: <http://www.pianoemgrupo.mus.br/maria.htm>. Acesso em: 22 nov. 2013. 
GONÇALVES, M. L. J.; BARBOSA, C. B. Ensino de piano em grupo no Brasil: qual é a sua Escola Pianística, [s.d.d]. Disponível em:

<http://www.pianoemgrupo.mus.br/maria_informal.htm>. Acesso em: 22 nov. 2013.

GOUVEIA, H. O. C. Os jogos (Játékok) de György Kurtág para piano: corpo e gesto numa perspectiva lúdica. Tese (Doutorado em Musicologia) - Escola de Comunicação e Artes, Universidade de São Paulo, São Paulo, 2010.

HARALD Bojé Discography. DSICOGS, 2014. Disponível em: <http://www.discogs.com/artist/14549-Harald-Boj\%C3\%A9>. Acesso em: 25 jun. 2014.

. Composers and Works. Universal edition. Disponível em:

<http://www.universaledition.com/Harald-Boje/composers-and-works/composer/79>. Acesso: 25 jun. 2014.

JEFFREY, B.; CRAFT, A. Teaching creatively and teaching for creativity: distinctions and relationships. Educational Studies, v. 30, n. 1, p. 77-87, 2004.

JORDÃO, G. et al. (Orgs.). A música na escola. São Paulo: Allucci \& Associados Comunicações, 2012. Disponível em: <http://www.amusicanaescola.com.br/oprojeto.html>. Acesso em: 2 jan. 2013.

JUNQUEIRA, M. F. P. Escola de música de Luigi Chiaffarelli. Tese (Doutorado em Comunicação) - Universidade Presbiteriana Mackenzie, São Paulo, 1982.

KATER, C. E. (Org.). H. J. Koellreutter: música e educação em movimento. In: (Org.). Educação musical: cadernos de estudo $\mathrm{n}^{\mathrm{O}}$ 6. Belo Horizonte: Atravez/EMUFMG/FEA/FAPEMIG, n. 6, 1997. p. 6-25.

KOELLREUTTER, H.-J. Educação musical hoje e, quiçá, amanhã. In: LIMA, Sonia Albano de (Org.). Educadores musicais de São Paulo: encontro e reflexões. São Paulo: Nacional, 1998. p. 39-45.

I Curso Internacional de férias.In: KATER, C. (Org.). Educação musical: cadernos de estudo nº 6. Belo Horizonte: Atravez/EMUFMG/FEA/FAPEMIG, 1997a. p. 26-28.

Seminários internacionais de música: abertura. In: KATER, C. (Org.). Educação musical: cadernos de estudo ${ }^{\circ} 6$. Belo Horizonte:

Atravez/EMUFMG/FEA/FAPEMIG, 1997b. p. 29-32.

Seminários internacionais de música: encerramento.In: KATER, C. (Org.).

Educação musical: cadernos de estudo $n^{\circ}$ 6. Belo Horizonte:

Atravez/EMUFMG/FEA/FAPEMIG, 1997c. p. 33-36.

. O Ensino da música num mundo modificado. In: KATER, C. (Org.). Educação

musical: cadernos de estudo $\mathrm{n}^{\circ}$ 6. Belo Horizonte:

Atravez/EMUFMG/FEA/FAPEMIG, 1997d. p. 37-44.

Por uma nova teoria da música, por um novo ensino da teoria musical. In: KATER,

C. (Org.). Educação musical: cadernos de estudo $n^{\circ} 6$. Belo Horizonte:

Atravez/EMUFMG/FEA/FAPEMIG, 1997e. p. 45-52. 
KOELLREUTTER, H.-J. O espírito criador e o ensino pré-figurativo. In: KATER, C. (Org.). Educação musical: cadernos de estudo $n^{\circ} 6$. Belo Horizonte:

Atravez/EMUFMG/FEA/FAPEMIG, 1997f. p. 53-59.

. Educação e cultura em um mundo aberto como contribuição para promover a paz. In: KATER, C. (Org.). Educação musical: cadernos de estudo ${ }^{\circ}$ 6. Belo Horizonte: Atravez/EMUFMG/FEA/FAPEMIG, 1997g. p. 60-68.

. Sobre o valor e desvalor da obra musical. In: KATER, C. (Org.). Educação musical: cadernos de estudo $n^{\circ}$ 6. Belo Horizonte: Atravez/EMUFMG/FEA/FAPEMIG, 1997h. p. 69-78.

A imagem do mundo na estética de nosso século. In: KATER, C. (Org.). Educação musical: cadernos de estudo $n^{\circ} 6$. Belo Horizonte:

Atravez/EMUFMG/FEA/FAPEMIG, 1997i. p. 103-108.

. Música, reparos e reflexões. In: KATER, C. (Org.). Educação musical: cadernos de estudo nº 6. Belo Horizonte: Atravez/EMUFMG/FEA/FAPEMIG, 1997j. p. 109-112.

. Entrevista: encontro com H. J. Koellreutter. In: KATER, C. (Org.). Educação musical: cadernos de estudo $\mathrm{n}^{\circ}$ 6. Belo Horizonte:

Atravez/EMUFMG/FEA/FAPEMIG, 1997k. p. 131-144. Entrevista concedida a Carlos Kater.

Terminologia de uma nova estética da música. Porto Alegre: Movimento, 1990.

KURTÁG, G. Játékok: zongorára. Vol. 7. Budapest: Musica Budapest, 2003.

Játékok: zongorára. Vol. 5. Budapest: Musica Budapest, 1997a.

Játékok: zongorára. Vol. 6. Budapest: Musica Budapest, 1997b.

Játékok: zongorára. Vol. 1. Budapest: Musica Budapest, 1979a.

Játékok: zongorára. Vol. 2. Budapest: Musica Budapest, 1979b.

Játékok: zongorára. Vol. 3. Budapest: Musica Budapest, 1979c.

Játékok: zongorára. Vol. 4. Budapest: Musica Budapest, 1979d.

LANÇAMENTO de livros na área de Educação Musical. UNIVERSIDADE DO ESTADO

DE MINAS GERAIS. Disponível em: <http://www.uemg.br/eventos.php?id=2692>. Acesso em: 25 jun. 2014.

LONGO, L. Divertimentos. São Paulo: [s.n], 2003.

Laura Longo. Currículo Lattes, 7 ago. 2013. Disponível em:

<http://lattes.cnpq.br/0272087023916650>. Acesso em: 12 dez. 2014.

LOVINSON, J. Dr. Robert Pace Method of Keyboard Instruction. Disponível em:

<http://www.renoweb.net/LSMS/pace.html>. Acesso em: 30 jan. 2014. 
MARINI, G. D. O tratado dos objetos musicais de Pierre Schaeffer revisitado pela fenomenologia de Merleau-Ponty. In: ENCONTRO DE PESQUISA EM MÚSICA, 4. , 2009, Maringá. Anais... Maringá: Universidade Estadual de Maringá, 2009.

MARINO, G. Gislene Marino Costa. Currículo Lattes, 30 jan. 2014. Disponível em: <http://lattes.cnpq.br/1670558239548904>. Acesso em. 23 mar. 2014.

; RAMOS, A. C. Piano 2: arranjos e atividades. Belo Horizonte: Cultura, 2009.

; RAMOS, A. C. Piano 1: arranjos e atividades. Belo Horizonte: Cultura, 2001.

MARIZ, V. História da música no Brasil. 5. ed. Rio de Janeiro: Nova Fronteira, 2000.

MATEIRO, T.; ILARI, B. (Orgs.). Pedagogias em educação musical. Curitiba: Ibpex, 2011. (Série Educação Musical.)

MONTANDON, M. I. Aula de piano e ensino de música: análise da proposta de reavaliação da aula de piano e sua relação com as concepções pedagógicas de Pace, Verhaalen e Gonçalves. Dissertação (Mestrado em Música) - Instituto de Artes, Universidade Federal do Rio Grande do Sul, Porto Alegre, 1992.

MORAES, M. C. O paradigma educacional emergente. Campinas: Papirus, 1997.

MOREIRA, A. L. I. G. Iniciação ao piano para crianças: um olhar sobre a prática pedagógica em conservatórios da cidade de São Paulo. Dissertação (Mestrado em Música) - Instituto de Artes, Universidade Estadual Paulista Júlio de Mesquita Filho, São Paulo, 2005.

MORIN, E. Os sete saberes necessários à educação do futuro. Trad. Catarina Eleonora F. Silva e Jeanne Sawaya. 2. ed. rev. São Paulo: Cortez/Brasília, DF: UNESCO, 2011.

MUSINFO. La Base de Données de la Musique Suisse. Disponível em: $<$ http://www.musinfo.ch/index.php?content=maske_personen\&pers_id=122>. Acesso em: 25 jun. 2014.

OLIVEIRA, M. L. As aventuras de "Alice no País das Maravilhas" e na EMIA: Winnicott e a educação. Tese (Doutorado em Psicologia) - Instituto de Psicologia, Universidade de São Paulo, São Paulo, 2009.

. Arte e construção do conhecimento na EMIA. São Paulo: Casa do Psicólogo, 2006.

OSTROWER, F. Criatividade e processos de criação. 2. ed. Petrópolis: Vozes, 1978.

PACE, R. Música para piano, livro 1. São Paulo: Ricordi, 1973a.

Criando e aprendendo, livro 1. São Paulo, Ricordi, 1973 b.

PASCOAL, M. L. Maria Lúcia Senna Machado Pascoal. Currículo Lattes, 20 jun. 2014. Disponível em: <http://lattes.cnpq.br/1957519903631670>. Acesso em: 25 jun. 2014.

PAYNTER, J.; ASTON, P. Sound and Silence. 6. ed. Cambridge: Cambridge University Press, 1985. 
PAYNTER, J. Hear and now: an introduction to modern music in schools. London: Universal, 1972.

QUALIFICATIONS AND CURRICULUM AUTHORITY. United Kingdom. Disponível em: <https://www.gov.uk/government/organisations/qualifications-and-curriculumauthority>. Acesso em: 5 jul. 2014.

RAMOS, A. C. Ana Consuelo Ramos. Currículo Lattes, 14 mar. 2014. Disponível em: <http://lattes.cnpq.br/7857274153178162>. Acesso em: 21 mar. 2014.

REYNER, I. R. Pierre Schaeffer e sua teoria da escuta. Opus, Porto Alegre, v. 17, n. 2, p. 77 106, dez. 2011. Disponível em:

<http://www.anppom.com.br/opus/data/issues/archive/17.2/files/OPUS_17_2_Reyner. pdf>. Acesso em: 12 abr. 2013.

ROCHA, A. C. R. Educação musical e experiência estética: entre encontros e possibilidades. Dissertação (Mestre em Educação) - Faculdade de Educação, Universidade Estadual de Campinas, Campinas, 2011.

ROBERT Pace Piano: Forward-Looking Teaching. Roberto Pace Piano. Disponível em: <http://www.leerobertsmusic.com/>. Acesso em: 25 jun. 2014.

SALLES, P. P. Gênese da notação musical na criança: os signos gráficos e os parâmetros do som. Revista Música, São Paulo, v. 7, n. 1/2, p. 149-183, maio/nov. 1996.

SAMPAIO, M. A. Métodos brasileiros de iniciação ao piano: um estudo sob o ponto de vista pedagógico. Dissertação (Mestrado em Música) - Centro de Letras e Artes, Universidade Federal do Estado do Rio de Janeiro, Rio de Janeiro, 2001.

SANTOS, F. C. A paisagem sonora, a criança e a cidade: exercícios de escuta e de composição para uma ampliação da ideia de música. Tese (Doutorando em Música) Instituto de Artes, Universidade Estadual de Campinas, Campinas, 2006.

SCHAEFFER, P. Traité des objets musicaux. Paris: Éditions du Seuil, 1966. Tratado dos objetos musicais. Trad. Ivo Martinazzo. Brasília: Dunb, 1993.

SCHLOCHAUER, R. B. Q. A presença do piano na vida carioca no século passado. Dissertação (Mestrado em Musicologia) - Escola de Comunicação e Artes, Universidade de São Paulo, São Paulo, 1992.

SIMONOVICH, A. (Org.). Apertura, identidad y musicalización: bases para una educación musical latinoamericana. Ed. Ciudad Autónoma de Buenos Aires: Foro Latinoamericano de Educación Musical, Argentina Asociación Civil, 2009.

STAKE, R. E. Pesquisa qualitativa: estudando como as coisas funcionam. Trad. Karla Reis. Porto Alegre: Penso, 2011.

SWANWICK, K. Ensinando música musicalmente. São Paulo: Moderna, 2003.

Musical knowledge: intuition, analysis and music education. Londres: Routledge, 1994. 
SWANWICK, K. Music, mind and education. Londres: Routledge, 1988.

TOURINHO, I. Encontros com Koellreutter: sobre suas histórias e seus mundos. Revista Estudos Avançados, São Paulo: IEA-USP, v. 13, n. 35, p. 209-223, 1999.

VILLAVICENCIO, C.; IAZZETTA, F.; COSTA, R. L. M. Fundamentos técnicos e conceituais da livre improvisação, [s.d.]. Disponível em:

$<$ https://www.academia.edu/2487867/Fundamentos_tecnicos_e_conceituais_da_livre_ improvisacao>. Acesso em: set. 2012.

WIDMER, E. Ludus brasiliensis: 162 peças progressivas para piano. São Paulo: Ricordi, 1966. $5 \mathrm{v}$.

WIDMER ERNST: Biographie. Musinfo. Disponível em:

<http://www.musinfo.ch/index.php?content=maske_personen\&pers_id=122>. Acesso em: 25 jun. 2014.

WINTER, L. L. O conceito de paradoxo para Ernst Widmer. Opus, v. 11, n. 11, p. 121-139, 2005.

ZABALA, M. J.; TUÑEZ, M. De tecla en tecla: experiencias iniciales en la ejecución pianística. 2. ed. Buenos Aires: El Farol Cooperativa de Trabajo Cultural, 2007. 


\section{ANEXO A \\ Carta à direção da EMIA \\ Programa de Pós-graduação em Música Departamento de Música da ECA-USP}

São Paulo, 4 de março de 2012.

À Direção da Escola Municipal de Iniciação Artística (EMIA)

De Maria Berenice Simões de Almeida

Ref.: Solicitação para realização de pesquisa de mestrado e encaminhamentos

\section{Prezada Diretora Márcia Andrade}

Encaminho em anexo meu projeto de pesquisa de mestrado, com a finalidade de comunicar a minha intenção de realizar minha pesquisa com alguns dos meus alunos de piano desta instituição. O projeto foi aprovado no Programa de Pós-graduação em Música da USP, já estou cursando as primeiras disciplinas e elaborando a pesquisa.

O objetivo desse projeto é pesquisar possibilidades de aprendizagem a partir de processos criativos no ensino de piano. Pretendo ainda pesquisar os processos do pensamento musical das crianças a partir de suas composições e também possíveis orientações para uma prática pedagógico-musical do professor que favoreça um ambiente criativo nas aulas de piano. O foco da pesquisa serão análises e reflexões pedagógico-musicais de algumas composições de meus alunos de piano.

Atendendo aos cuidados éticos da pesquisa, me comprometo a redigir e encaminhar aos pais ou responsáveis dos alunos um comunicado e um Termo de Autorização, em que permitirão que as crianças participem da referida pesquisa. $\mathrm{O}$ material gravado também ficará à disposição dos pais por seis meses, garantindo-lhes - bem como à Escola - o direito de pedir o corte de algum trecho.

Convém destacar que a pesquisa atende a todas as disposições legais do Conselho Nacional de Ética em Pesquisa - CONEP e do Conselho Nacional de Saúde sobre pesquisas com seres humanos (Resoluções n. 196/1996 e n. 251/1997, do CNS). Preocupada também com o retorno da pesquisa para a instituição, comprometo-sme a apresentar o trabalho concluído à comunidade e ceder à Escola uma cópia da dissertação. Concluída a coleta de dados, a instituição também poderá solicitar um DVD contendo uma síntese das filmagens realizadas.

Para qualquer informação adicional, coloco-me à disposição da equipe pedagógica e dos pais dos alunos participantes. Agradeço sua disponibilidade e a de sua equipe pedagógica de analisar meu projeto e aguardo retorno.

Cordialmente,

Maria Berenice Simões de Almeida

Contato: 11981996026 | E-mail: beremusica@gmail.com 


\section{ANEXO B}

\section{COMUNICADO AOS PAIS OU RESPONSÁVEIS}

Prezados pais,

Gostaria de manifestar meu interesse em fazer minha pesquisa de mestrado na aula de música que seu filho frequenta em nossa instituição. O trabalho é orientado pela $\operatorname{Prof}^{\mathrm{a}} \operatorname{Dr}^{\mathrm{a}}$ Maria Teresa Alencar de Brito, do Programa de Pós-graduação em Música da Escola de Comunicações e Artes da Universidade de São Paulo - USP. O título da pesquisa é Processos criativos no ensino de piano, e o trabalho de campo envolve filmagem em vídeo das aulas e depoimentos, em forma de entrevista livre, gravados regularmente durante o curso.

Isto posto, venho pedir sua autorização para o uso da imagem e do áudio registrados em vídeo de seu(sua) filho(a). A finalidade é apenas ilustrar a discussão pedagógica da pesquisa. As imagens serão exibidas apenas em contexto acadêmico, ou seja, na universidade, em congressos ou palestras onde se desenvolve essa discussão. No caso dos depoimentos, seu(sua) filho(a) é convidado(a) a falar sobre o próprio processo de criação musical.

Antes do exame de qualificação, que acontecerá em setembro de 2013, os vídeos estarão disponíveis para os senhores por seis meses, garantido-lhes o direito de pedirem o corte de algum trecho. A identidade das crianças será protegida por pseudônimos. Em poder da direção pedagógica da Escola, há um resumo do projeto de pesquisa contendo informações mais detalhadas. Se houver necessidade de qualquer esclarecimento adicional, coloco-me à disposição nos contatos abaixo. Espero contar com sua ajuda e peço que a autorização em anexo seja assinada o mais breve possível.

Muito obrigada.

Maria Berenice Simões de Almeida

tel: 981996026

email: beremusica@gmail.com

São Paulo, 20 de março de 2012. 


\section{AUTORIZAÇÃO}

São Paulo, 20 de março de 2012.

$\mathrm{Eu}$,

de

Iniciação Artística do DEC - Departamento de Expansão Cularal da SMC Secretaria Municipal de Cultura de São Paulo, autorizo o uso da imagem e da gravação de áudio de meu(minha) filho(a) no projeto de pesquisa do PPGMUS - Programa de Pós-graduação em Música da USP - Universidade de São Paulo, Processos criativos no ensino de piano, da professora de música desta Escola Maria Berenice Simões de Almeida, nas seguintes condições:

- As imagens e gravações de áudio do(a) aluno (a) serão usadas exclusivamente para a pesquisa de mestrado da supramencionada professora, na produção da dissertação, em artigos acadêmicos e comunicações ou palestras em congressos nacionais ou internacionais relacionados ao tema da referida pesquisa.

- O nome de meu(minha) filho(a) será substituído por outro qualquer, de escolha da referida professora, em todos os textos, vídeos e áudios.

- A professora Maria Berenice Simões de Almeida se compromete a entregar à família um DVD com as imagens e áudios utilizados na pesquisa, após o término do PPGMUS, que deverá ocorrer em julho de 2014. Caso seja de interesse dos pais, a professora também disponibilizará o endereço eletrônico no qual a dissertação será arquivada. 